UC.70

Reporting Date: February 1976 Issued: July 1976

\title{
Incineration Facilities for Treatment of Radioactive Wastes: A Review
}

by

Betty L. Perkins

lOS ALAMOS, NEW MEXICO Bi J45

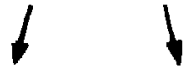

An Aflirmative Action, Equal Opporfunily Employer 
Printed in the United States of America. Available from National Technical Information Service

U.S. Depariment of Commerce

S285 Port Royal Road

Springfield, VA 22161

Price: Printed Copy \$5.00 Mir:ofiche $\$ 2.25$ 


\section{CONTENTS}

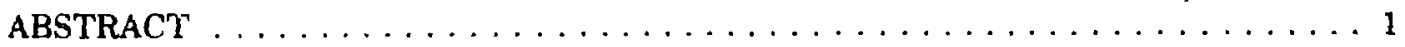

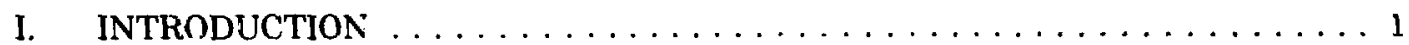

II. FOREIGN INCINERATION FACILITIES $\ldots \ldots \ldots \ldots \ldots \ldots \ldots \ldots \ldots$

A. United Kingdom . . . . . . . . . . . . . . . . . . . . 1

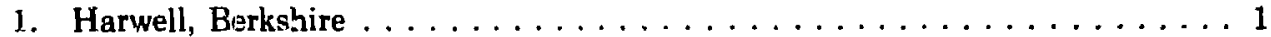

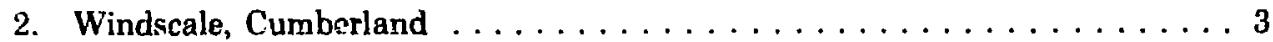

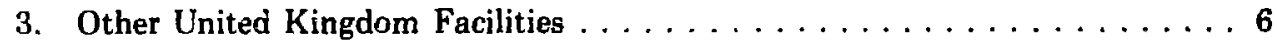

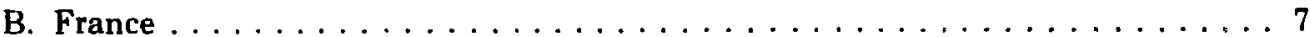

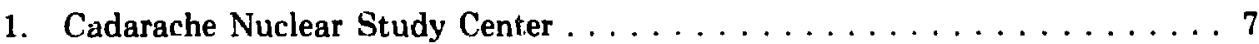

2. Fontenay-aux-Roses (CEN-FAR) $\ldots \ldots \ldots \ldots \ldots \ldots \ldots$

3. National Centet for Scientific Research

(CNRS), Strasbourg-Cronenbourg . . . . . . . . . . . . 9

4. Marcoule Center of Plutonium Production,

Bagnols-sur-Ceze . . . . . . . . . . . . . . . . . . 11

5. Center of Nuclear Studies, Grenoble (CEN-G) $\ldots \ldots \ldots \ldots \ldots \ldots \ldots$

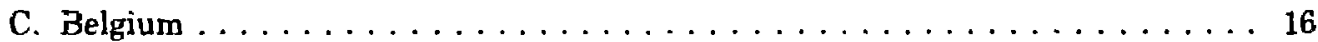

1. Belgium Nuclear Center, $\operatorname{Mol}(\mathrm{CEN}) \ldots \ldots \ldots \ldots \ldots \ldots$

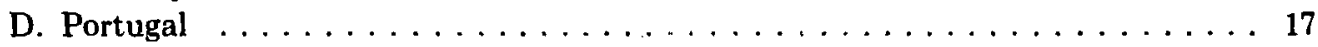

1. Sacavein Center ....................... 17

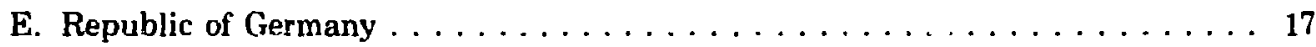

1. Nuclear Research Center, Karlsruhe . . . . . . . . . . . . . 17

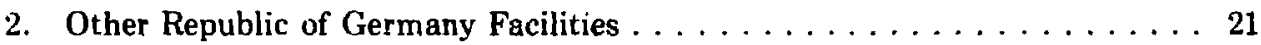

F. India . . . . . . . . . . . . . . . . . . . 22

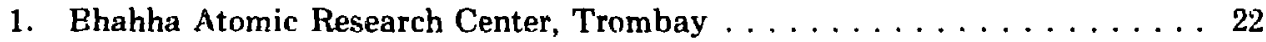

G. Japan . . . . . . . . . . . . . . . . . . . . . 23

1. Japanese Atomic Energy Research Institute

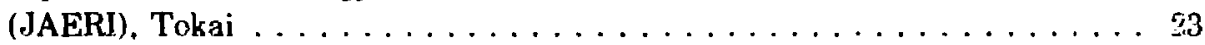

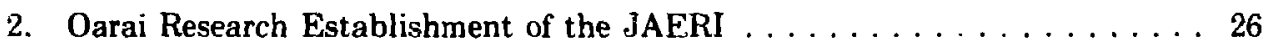

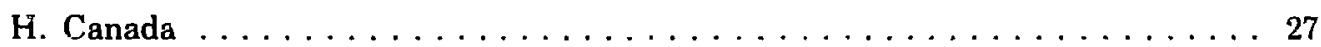

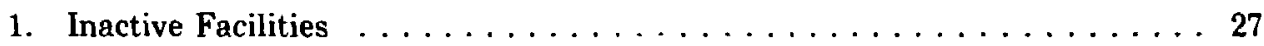

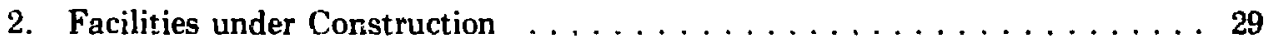

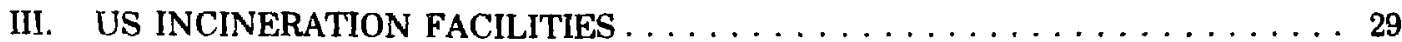

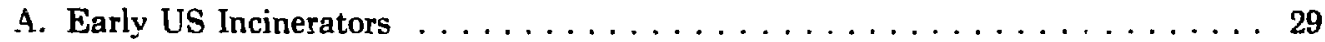

1. Mound Laboratory, Miamisburg, $\mathrm{OH} \ldots \ldots \ldots \ldots \ldots$

2. Knolls Atomic Power Laboratory (KAPL),

Schenectady, NY . . . . . . . . . . . . . . . . . . . . . . 32

3. Árgonne National Laboratory (ANL), Argonne, IL . . . . . . . . . . 33

A. Los Alamos Scientific Laboratory (LASL).

Los Alamos, NM . . . . . . . . . . . . . . . . . . . 35

5. Bettis Atomic Power Laboratory, West Mifflin, PA . . . . . . . 3 E

6. Shippingport Atomic Fower Station, Shippingport, PA . . . . . . . . . . . . . . . . . . . . . . 37

7. United Nuclear industries, Inc., Richland, WA . . . . . . . . . . 37 
8. Bureau of Mines, Combustion Research Section,

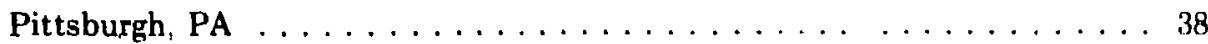

9. Harvard Air Cleaning Laboratory (ACL), Boston . . . . . . . . . . 40

10. US Army Nuclear Defense Laboratory, Edgewood Arsenal, MD . . . . . . . . . . . . . . . . . . . . . . . 41

11. Other US Facilities Operated in the Early 1960 's for Incineration of Uranium-Containing

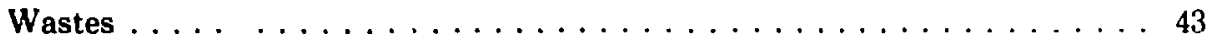

12. General Electric Atomic Power Equipment Department, San Jose, CA . . . . . . . . . . . . . . . . . . . . . 44

13. Nuclear Materials and Equipment Corp. (NUMEC),

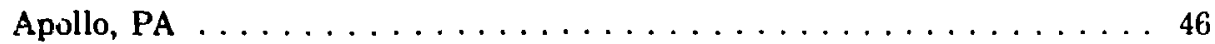

B. Present US Incinerators $\ldots \ldots \ldots \ldots \ldots \ldots \ldots \ldots \ldots \ldots \ldots \ldots$

1. National Lead Co. of Ohio (NLCO), Fernald, $\mathrm{OH} \ldots \ldots \ldots \ldots \ldots \ldots . . . .47$

2. United Nuclear Corp., Wood River Junction, RI . . . . . . . . . . 49

3. Goodyear Atomic Corp., Piketon, $\mathrm{OH} \ldots \ldots \ldots \ldots \ldots \ldots \ldots \ldots$

4. Union Carbide Corp., K-25 Plant, Oak Ridge, TN . . . . . . . . . 51

5. Union Carbide Corp., Paducah, KY . . . . . . . . . . . . . . 51

6. Union Carbide Corp., Y-12 Plant, Oak Ridge, TN . . . . . . . . . 52

7. Gulf General Atomics (GGA), Nuclear Materials

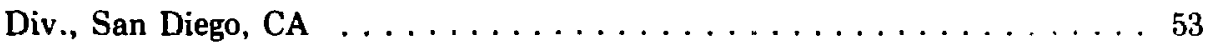

8. General Electric Nuclear Fuel Plant, Wilmington, NC . . . . . . . . . 54

9. Westinghouse Nuclear Fuel Division, Columbia, SC . . . . . . . . 56

10. Nuclicar Fuel Services, Inc., Erwin, TN . . . . . . . . . . . . . 59

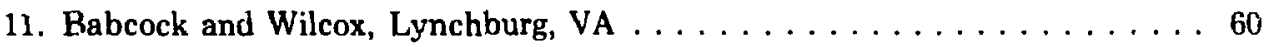

12. Yankee Atomic Electric Co., Rowe, MA . . . . . . . . . . . . 60

13. Kerr-McGee Nuclear Corp., Crescent, OK . . . . . . . . . . . 61

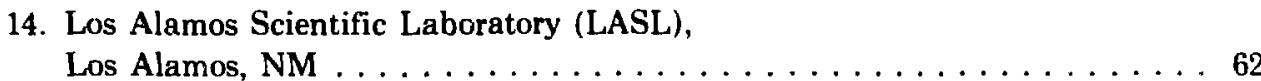

15. Mound Laboratory, Miamisburg, $\mathrm{OH} \ldots \ldots \ldots \ldots \ldots$

i6. Rockwell International, Rocky Flats, $\mathrm{CO} \ldots \ldots \ldots \ldots \ldots \ldots \ldots$

17. Atlantic Richfield Hanford Co. (ARHCO), Richland, WA . . . . . . . . . . . . . . . . 76

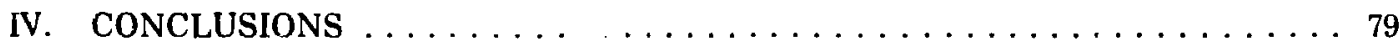

A. Problem Areas $\ldots \ldots \ldots \ldots \ldots \ldots \ldots \ldots \ldots \ldots \ldots \ldots \ldots \ldots \ldots$

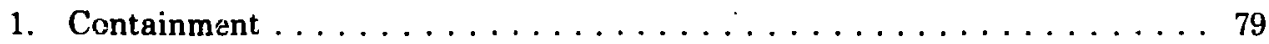

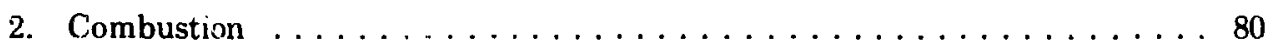

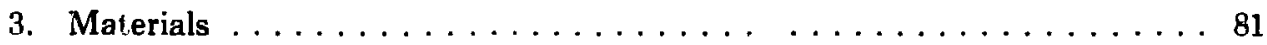

4. Criticality Control $\ldots \ldots \ldots \ldots \ldots \ldots \ldots \ldots \ldots \ldots$

B. Incineration vs Radionuclide Content and Waste Type . . . . . . . . . 84

1. Radionuclide Content . . . . . . . . . . . . . . . . . . 84

2. Waste Typc . . . . . . . . . . . . . . . . . 84

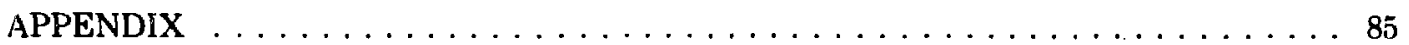




\title{
INCINERATION FACILITIES FOR TREATMENT OF RADIOACTIVE WASTES: A REVIEW
}

\author{
by
}

Betty L. Perkins

\begin{abstract}
A description is given of incinerator installations in the US and in foreign countries. Inuluded are descriptions of inactive incinerators, incinerator facilities currently in operation, and incinerator installations under construction. Special features of each installation and operational problems of each facility are emphasized. Problems in the incineration of radioactive waste are discussed in relation to the composition of the waste and the amount and type of radioactive contaminant.
\end{abstract}

\section{INTRODUCTION}

The purpose of this report is to provide a compendium of the information available as of June 1975 on the use of incineraturs tor treatment of solid wastes contaminated with radionuclides. Because of limited time and funds and the difficulty in obtaining information, not every facility has been included. For example, Russian-operated facilities are not discussed.

The information was obtained from responses to written inquiries, from telephone calls, from interviews, and from articles in the open iiterature. ${ }^{*}$ No attempt was made to verify reported information, except that in cases where the data were obtained by telephone, the ensuing writeup was sent to the staff at that installation for comments.

Details of volume reduction and cost have, in general, been excluded. A true indication of volume reduction must include such items as frequency of replacement of contaminated parts, disposal of generated radioactive liquors, disposal of contaminated filters, treatment of clothing worn by cperators, and final stabilization of the ash. Little information is available on these aspects of incinerator operation.

*Sources are listed at the end of the discussion of each installation.
No discussion of cost is included because rapid inflation renders such a discussion obsolece. Current costs of commercially available incinerators, scrubbing systems, etc., are available from vendors. In addition, a cost analysis of incineration makes little sense if comparative costs for drum storage, retrieval, processing and final sturage, atc., are not available. The experience at Rocky IIlats* indicates that incineration costs are not the major expense in radionuclide recovery.

\section{FOREIGN INCINERATION FACILITIES}

\section{A. United Kingdom}

1. Harwell, Berkshire. Eacly in the operation of Harwell it became evident that on-site storage of solid radioactive wastes without treatment was not feasible. Because $\sim 60$ vol $\%$ of the wastes were combustible, volume reduction through incineration was considered desirable.

a. Pilot Incineratcr. In 1950 a small experimental incinerator (Fig. 1) was constructed to ascertain the

${ }^{*} R$. S. Foster, "Incineration of Plutonium Contaminated Waste Materials," Dow Rocky Flats report RFP-735 (Muy 1966). 


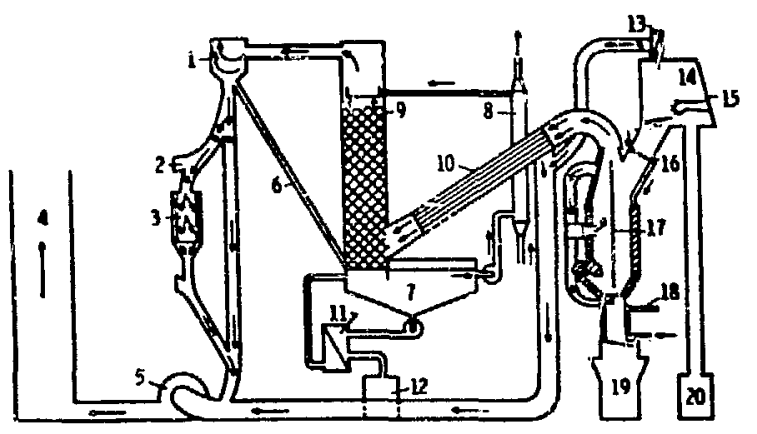

11. SCRUABINGH IOLOR FILIER 12. FILIER-BACKLAS CH CONTA? ER 13. PAPER FILIER

14. SORTING E CHARGING BOX

is. PERSPEX WINDONY

16. CMBUSTION-AIR INAT

17. SIAIMISS-STEE GRIO

18. WhTER-COOLEO ASH HOPPER

18. WhTER-COOLED A

20. NONCOMBUSTIBLE CONTAIKER

Fig. 1.

Pilot incinerator at Harwell.

difficulties that might be involved in incineration. Despite some operational difficulties, the facility ran for $3 \mathrm{yr}$.

b. Second Incinerator. In 1954 a larger incinerator was built (Fig. 2). Its combustion chamber was made of unlined stainless steel. To avoid materials problems with the steel, it was necessary to operate at such low temperatures that complete combustion was not always possible. In addition, the acidic products of combustion, particularly the chlorine compounds from polyvinyl chloride (PVC) and similar materials. rapidly corrcded the metallic

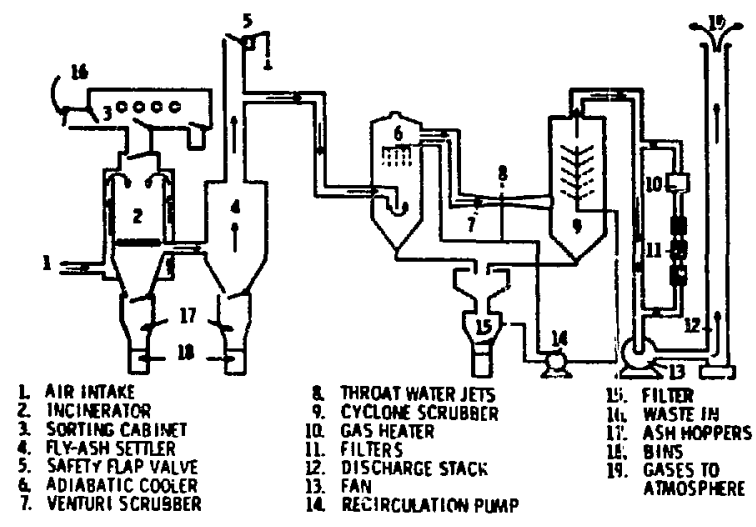

Fig. 2.

Second incinerator at Harwell. parts. During the first few years of operation there were frequent breakdowns; herice maintenance costs were high. The number of breakdowns was reduced in later years by (1) using different materials for replacement parts, (2) achieving better $\mathrm{pH}$ control, (3) achieving better filtration of the scrubbing liquors, and (4) improving operating techniques. For this second facility, $\sim 95 \%$ of the activity was retained in the ash, $\sim 4.5 \%$ in the scrubbing system, and $0.5 \%$ in the filters.

c. Third Incinerator. By the later 1950's, the amount of solid wastes requiring incineration had increased, and the second facility continued to have operating problems. Therefore, in 1959 another incineraíor (designed to handle $180 \mathrm{~kg} / \mathrm{h}$ ) was constructed (Fig. 3).

The chamber of this unit was lined wilin refractory bricks to permit operation at higher temperatures. A dry filtration sysitem consisting of woven glass -fiber bags followed by high-efficiency filters was installed. On three occasions during the first 6 months, material that was caught on the primary bag filters ignited; consequently, the dry off-gas train was replaced with the wet system from the second in cinerator.

This third unit, using the wet off-gas system, has operated at a throughput of $\sim 100 \mathrm{~kg} / \mathrm{h}$. The $\mathrm{pH}$ of the scrub solution is controlled by the addition of $\mathrm{NaOH}$. The liquid is filtered through sand beds to remove entrained material.

d. Fourth Incinerator. In 1962 a small experimental incinerator was built to study further the incineration and off-gas cleanup problems of solid

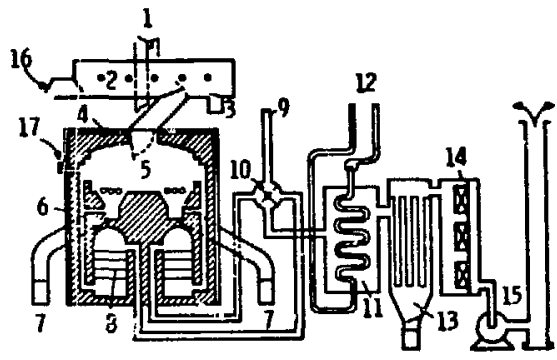
1. PRES SURE RELIEF VALVE
2. SORTING CABINFT
3. NON COMBIJSTIBLES
4. REFRACTORY LININO
5. FUR NACE AREA
6. FIRE BARS
7. ASH BINS
8. REGENERATORS
9. AIR INTAKE

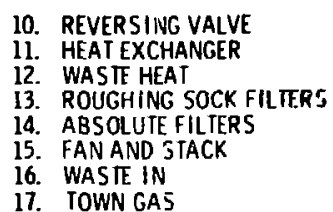

10. REVERSIIUG VALVE

11 HEAT EXCHANGER

12. WASIF HEAT

13. ROUGHING SOCK FILTERS

15. FAN AND STACK

17. IOWN

Fig. 3.

Third incinerator at Harwell. 
radioactive wastes (Fig. 4). The design criterıa for this pilot plant were simplicity and maintainability.

The incinerator consists of brick-lined primary and secondary chambers. The secondary chamber contains refractory-brick baffles. Both overfire and underfire air can be used in the primary chamber.

The cooler unit cools the gases to $<200^{\circ} \mathrm{C}$. The cooler was designed for ease in cleaning as the result of cleaning difficulties experienced with the third incinerator.

The dry off-gas cleanup system consists of a cyclone and an electrostatic precipitator which has slowly rotating collector plates with fixed scraper blades. Provision has also been made for using highefficiency filters and a wet scrubbing system as an alternative or in addition to the dry system. The facility has been instrumented with pressure, temperature, $\mathrm{CO} / \mathrm{CO}_{2}$, and particulate and gas monitoring and sampling equipment. The main objectives of the pilot incinerator program are: (1) To compare underfire with overfire air flow in the furnace; (2) to establish optimum operating conditions in the system during inactive runs; (3) to establish, on active runs, the retention efficiency for radionuclides; (4) to compare the cleaning efficiencies of various types of wet- and dry-exhaust gas cleanup systems; and (5) to burn low-level radioactive wastes on a routine basis, using the most promising of the wet and dry systems found in (4) above and, during this period, to study the lifetime of the materials used in construction and to consider the overall radiological safety of the plant.

If the primary temperature is $<800^{\circ} \mathrm{C}$ in this system, a large amount of soot will be found in the gases. With a feed rate of $27 \mathrm{~kg} / \mathrm{h}$ and $170 \mathrm{~m}^{3} / \mathrm{h}$ of combustion air, a weight reduction factor of 13 has been obtained.

in 1970 work was proceeding on this project only when manpower was available. Work on the facility was not of high priority because the third incinerator was working satisfactorily.
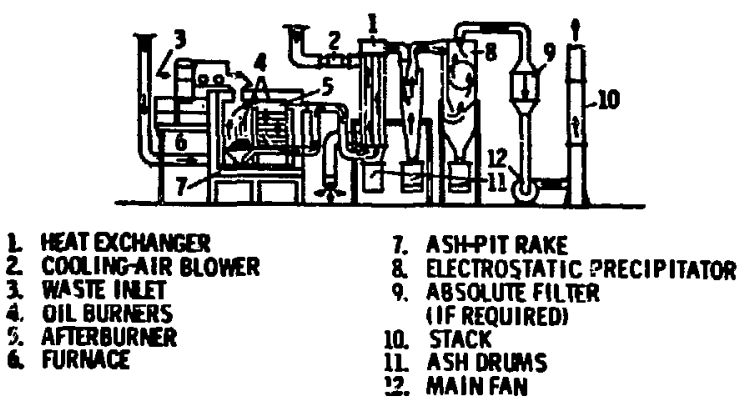

Fig. 4.

Fourts incinerator at Harwell.

\section{SOURCES}

J. Pradel, P. J. Parsons, and E. Malasek, "The Volume Reduction of Low-Activity Solid Wastes," IAEA Technical Report Series No. 106 (1970), pp. 29-32.

R. H. Burns, G. W. Clare, A. J. Smith, and D. A. Dunkason, "The Treatment of Low-Level Solid Wastes at the Atomic Energy Research Establishment, Harwell," in Proc. Symp. Practices in Treatment of Low- and Intermediate-Level Padioactive Wastes, Vienna, December 6-10, 1965 (JAEA, Vienna, 1966), pp. 646-653.

R. H. Burns and J. H. Clarke, "Harwell Experiences in Waste Management," in Proc. Symp. Developments in Management of Low- and Intermediate-Level Radioactive Wastes, Aix-enProvence, September 7-11, 1970 (IAEA, Vienna, 1970), pp. 424-426.

Visit to Harwell by LaMar Johnson, LASL, 1974.

B. Owen, Rockwell International, Rocky Flats, personal communication, 1975.

R. H. Burns, "The Lisposal of Radioactive Solid Wastes," in Radioactive Wastes, Their Treatment and Disposal, J. C. Collins, Ed. (John Wiley and Sons, New York, 1960), pp. 190-196.

\section{Windscale, Cumberland}

Pilot Incinerator. In January 1973 the British began burning wastes containing radioactive materials in a small pilot-plant incinerator at

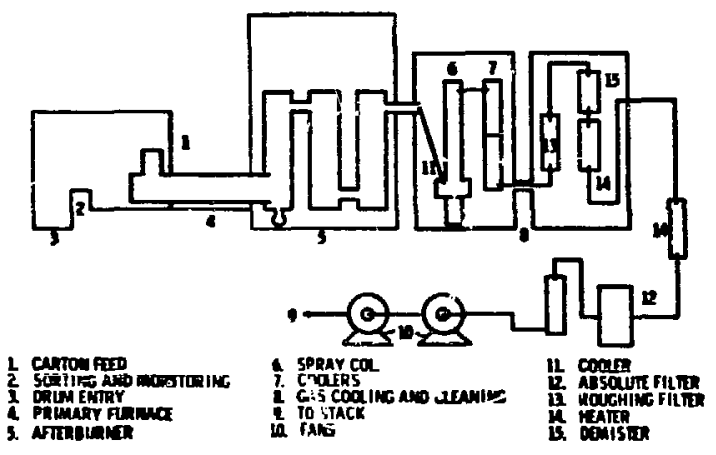

Fig. 5.

Pilot incinerator at Windscale. 
Windscale (Fig. 5). By May 1974, when the incinerator was shut down for modifications, the total running time had been 217 days, during which 13400 $\mathrm{kg}$ of wastes containing $15.5 \mathrm{~kg}$ of plutonium had been incinerated and the 'waste reduced to $600 \mathrm{~kg}$ of ash. The feed rate during sach campaign was about 5 $\mathrm{kg} / \mathrm{h}$. This facility is stili ir use at Windscale.

Pretreatment of Wastes. The 250-/ drums containing plutonium-contaminated wastes are carried by trolley into the system. The drums are opened and the bags of waste are lifted from the drums (by using tongs or reinforced gauntlets) and transferred to the waste receipt box. The bags are opened and check-sorted to insure that noncombustibles have been removed. Bulky items are shredded. Next, the waste is packed into cardboard boxes about $12.1 \mathrm{~cm}$ (5 in.) in diameter and $22.8 \mathrm{~cm}$ (9 in.) long; weight per carton is $\sim 800-1000 \mathrm{~g}$. The wastes contain $\sim 40 \%$ PVC, $\sim 30 \%$ rubber, $\sim 20 \%$ polyethylene, and $\sim 10 \%$ cellulose, etc., by weight.

Plutonium assay is made as the cartons rotate past a counter that detects $385-\mathrm{keV}$ gammas. (When the system has been fed $2 \mathrm{~kg}$ of plutonium, the incinerator is shut down for cleaning and inspection.)

Loading. A carton is fed into the cold end of the incinerator through a double-doored chute, and pushed with a ram into the burning zone. The area where the feed tube is bolted to the furnace tube is water-cooled to reduce the temperature in the feedtube glove box. To prevent large volumes of air from entering the furnace during feeding and to prevent "blowbacks," only one door of the chute can be open at any time.

Incinerator Design. The primary horizontal furnace, $30.48 \mathrm{~cm}(1 \mathrm{ft})$ in diameter and $167.64 \mathrm{~cm}(5.5$ $\mathrm{ft}$ ) long, is constructed of $0.95-\mathrm{cm}$ (3/8-in.)-thick Inconel-600. The end that enters the brickwork of the afterburner is double-walled, forming an annulus through which the afterburner air-feed passes. The incinerator contzins a ram feeder $91.4 \mathrm{~cm}$ long with a crescent-shaped prow at the forward end. As well as serving to introduce waste into the heated zone of the furnace, the ram prevents the ash and burning waste from blocking the gas flow through the furnace.

The primary furnace is heated electrically to $\sim 900^{\circ} \mathrm{C}$ by an external heat-diffuser plate, on which are mounted six (two banks of three) $18-\mathrm{kW}$ Nichrome wire elements. The chamber of this furnace operates with $10-20 \%$ stoichiometric air; hence, much of the off-gassing results from volatilization, not oxidation. Thermocouples are used to monitor furnace temperature. If the temperature exceeds a preset level, the furnace is automatically shut down. Pressure, also measured in the primary furnace, cannot exceed $-50 \mathrm{~Pa}(-0.2$ in. water gauge) or the air supply is cut off. The nitrogen supply, which serves as an alternative gas for the primary is cut off if the pressurt exceeds $-250 \mathrm{~Pa}(-1$ in. water gauge).

The vapors and carbon particles from the primary furnace pass into a secondary burner consisting of three separate vertical chambers in series. These chambers, $30.48 \mathrm{~cm}(1 \mathrm{ft})$ by $45.72 \mathrm{~cm}(1.5 \mathrm{ft})$ by $167.64 \mathrm{~cm}(5.5 \mathrm{ft})$, are constructed of $\mathrm{rEf}$ ractory bricks lined with a proprietary glazing cement. This size allc'ws $\sim 15 \mathrm{~s}$ of residence time for passage of the gases through the burner.

The chambers are heated electrically by Crusilite silicon-carbide elements. The gas temperature runs between $900-1000^{\circ} \mathrm{C}$. Excess air is maintained in these chambers to promote complete oxidation. Should a pressure excursion of $13800-34500 \mathrm{~Pa}$ (2-5 psi) positive pressure occur in any chamber, the gases vent through bursting disks to an expansion chamber designed to contain the excess gases safely. As a further safety measure, all the enclosures around the furnaces are under nitrogen purge.

Off-Gas Cleanup. The complete gas-cooling and -cleaning system is housed in two glove boxes, shown in Fig. 5, which are made from Darvic in three molded sections welded together. They are tested to high leak-rate standards.

Hot gases passing from the secondary burner enter a stainless-steel downpipe, air-to-air heat exchanger having a wall thickness of $1.27 \mathrm{~cm}$. Here the air that will be introduced into the furnace is preheated before entry into the combustion chambers, and the hot flue gases are cooled to $\sim 700^{\circ} \mathrm{C}$. The flue gases then pass through a pot formed from a cube of graphite into a packed column constructed of graphite in two sections, with graphite rings as packing. Water sprays at the top of this column cool and fully saturate the gases. About $90 \%$ of the original $\mathrm{HCl}$ in the hot off-gas plus some particulate matter are removed in the process. The gases exit the scrubber at $\sim 100^{\circ} \mathrm{C}$.

They next pass intn two glass, water-cooled condensers where most of the water vapor condenses and the gases are further cooled. Water is also sprayed into the condenser top to remove further $\mathrm{HCl}$ from the gas.

The cooled and dried off-gas is passed intn another glove-box system. Here the gases pass through a polyethylene-felt roughing filter and a polyethylene-felt demisting filter. This glove-box system also contains the liquol-filtering, monitoring, 
disposal, and recycling system for the scrubbing liquor from the spray scrubber-cooler units and the filter-demisting units. The liquid-treatment system is specifically constructed of materials resistant to attack by $\mathrm{HCl}$.

After the entrained inist has been removed from the gases, they are reheated to $60^{\circ} \mathrm{C}$ and then pass through absolute filters, through the induced-draft fan system, and exit to the ambient air. The fan system has duplicate polypropylene fans of 0.236 $\mathrm{m} / \mathrm{s}$ capacity capable of providing $5220 \mathrm{~Pa}$ (21 in. water gauge) depression.

Ash Removal. Residues in the bottom of the primary furnace are displaced progressively down the primary furnace until they iall onto the floor of the first chamber of the secondary burner. Here the carbon residue is burned off and the ash remains. The floor of the chamber also collects ash from any particulate residue that may have been carried over and burned in the gas stream in this chamber. The residual carbon content of the ash is usually in the range of $2-4^{\circ} \dot{c}$, although it has ranged as high as $22^{\circ} ;$; thus there is not complete oxidation of carbon.

A 15.24-cm (6-in.)-diam Inconel tube connects the ash pit to a flange on the afterburner face. $T^{*}$ remove the ash, a steel container is attached to the flanged opening and the ash is raked manually down the tube. When the ash is cool it is packed into aluminum cans for monitoring and storage. Since only $2 \mathrm{~kg}$ of plutonium are permissible in the ash, the ash must be removed at least every 4 days. The unit must be certified as being clean before feeding can be resumed.

Liquid Handling. The effluent liquors are passed through a filter and then monitored by a $17-\mathrm{keV}$ detector that faces a shielded polypropylene cell through which the liquors flow before passing into the active drains. About $70-90 /$ of effluent liquor, containing approximately $0.5 \mathrm{M} \mathrm{HCl}$, are discharged per hour.

Plutonium Balance. Out of $15.5 \mathrm{~kg}$ of plutonium fed into the incinerator, most remained in the ash. The liquid effluent contained $65 \mathrm{~g}$ of plutonium, and the total gaseous effluent contained $<20 \mu \mathrm{g}$.

The roughing filters need to be changed every few days. The plutonium activity on most demisting filters and all absolute filters (changed about every 6 wk) has been low enough ( $<.50 \mathrm{cps})$ to permit trench disposal. The undiluted gaseous effluent to the atmosphere rarely exceeds $4 \mathrm{dpm} / \mathrm{m}^{3}$.
A very fine, brown ash is present throughout the system, but its chemical composition has not been mentioned in the literature.

Problems. Five major problems have been encouncered during the Windscale incinerator operation.

(1) When rubber gloves were fed to the incinerator, large quantities of soot formed. This problem has been solved to some extent by in. creasing the primary furnace temperature to $1000^{\circ} \mathrm{C}$, by maintaining sufficient oxygen in the secondary burner, and by maintaining a more stringent control on feed composition.

(2) The silicon-carbide heating elements have a limited life, and require periodic repair.

(3) Off-gas demisting has been incomplete and the absolute filters must be changed more frequently than would otherwise be necessary.

(4) Corrosion in the gas-cleaning boxes has been so severe that metal items have been dispensed with wherever possible.

(5) Corrosion through the tube is a problem in the main primary furnace. This corrosion is thought to be due to the formation of a nickel/nickel sulfide, low-melting-point eutectic, and rubber gloves are considered to be the source of the sulfur. At present, a replacement-hearth system is being used. Tests are being carried out to identify materials and procedures to reduce tube corrosion.

\section{SOURCES}

G. Mathews, "The Windscale Pilot Plant for the Incineration of Active Wastes," October 1974.

H. A. Taylor, R. H. Allardice, J. G. Boyle, L. P. O'Conner, and M. J. S. Smith, "UK Experience in the Management of $\mathrm{Fu}$ Contaminated Solid Wastes," in Proc. Seminar Management of Plutonium-Contaminated Solid Wastes, Marcoule Center, France, October 14-16, 1974 (ERDA report CONF-741026).

J. G. Boyle, and H. A. Taylor, "Plutonium Waste Incinerator Pilot Plant," UK-USA Plutonium Waste Management Information Exchange Meeting, Los Alamos Scientific Laboratory, Los Alamos, NM, August 30-31, 1973. 


\section{Other United Kingdom Facilities}

Bradwell, Berkeley, Hunterston "A." Incinerators are also in use for volume and mass reduction of combustible, low-level radioactive wastes at Bradwell Power Station, Berkeley Nuclear Laboratories (BNL), and Hunterston "A." These wastes result from the operation of nuclear power stations of the Central Electricity Generating Board and Scuth of Scotland Electricity Board and are not stored at the stations themselves. The wastes usually consist of air filters, protective clothing, protective floor covering, swabs, paper handkerchiefs, and towels. Data on the amount of waste and controls applied to the waste are given in Table I.

The Bradwell incineratcr off-gases are cleaned by a cyclone and absolute filters. Treatment at the BNL unit consists of water-scrubbing anu filtration by absolute filters. Both units employ afterburners. The ash from incineration is accumulated at the incinerating site.

The Bradwell and BNL incinerators are shut down for considerable periods for maintenance and plant modifications, and a large backlog of waste accumulates. Consideration has been given to letting each station burn some of the least active combustible wastes in a small local incinerator to relieve some of the backlog on the large incinerator installations.

\section{SOURCES}

I. Dougall and J. E. Newell, "Management of Lowand Intermediate-Level Radioactive Wastes at the Nuclear Power Stations of the United Kingdom Central Electricity Generating Board," in Proc. Symp. Developments in Management of Low- and Intermediate-Level Radioactive Wastes, Aix-enProvence, September 7-11, 1970 (L:EA, Vienna, 1970), pp. 282-283.

I. Dougall, "The Management of Radioactive Wastes from Commercial Nuclear Power Stations in The Inited Kingdom," in Management of Radioactive Wastes at Nuclear Power Plants, IAEA Safety Series No. 28 (IAE'A, Vienna, 1968), pp. 124-127.

TABLE I

\section{DATA ON OPERATION OF THREE UK RADIOACTIVE-WASTE INCINERATORS}

\begin{tabular}{|c|c|c|c|}
\hline & Bradwell & BNL & Hunterston "A" \\
\hline $\begin{array}{l}\text { Period to which } \\
\text { data relate }\end{array}$ & 1967 & $\begin{array}{l}\text { November } 1965- \\
\text { December } 1966\end{array}$ & 1967 \\
\hline Weight of waste burned & $18160 \mathrm{~kg}$ & $38644 \mathrm{~kg}$ & $73.6 \mathrm{~m}^{3}$ (vol. burned) \\
\hline Weight of ash produced & $454 \mathrm{~kg}$ & $2186 \mathrm{~kg}$ & - \\
\hline $\begin{array}{l}\text { Volume (approx.) of } \\
\text { ash }^{\mathrm{a}} \text { produced }\end{array}$ & $2.04 \mathrm{~m}^{3}$ & $9.74 \mathrm{~m}^{3}$ & $3.4 n^{3}$ \\
\hline $\begin{array}{l}\text { Volume of spent } \\
\text { filters produced }\end{array}$ & $10.19 \mathrm{~m}^{3}$ & $3.82 \mathrm{~m}^{3}$ & NIL \\
\hline $\begin{array}{l}\text { Controls applied to } \\
\text { waste burned }\end{array}$ & $\begin{array}{l}<7.5 \mathrm{mR} / \mathrm{h} \text { at sur- } \\
\text { face of any waste } \\
\text { container }\end{array}$ & $\begin{array}{l}<15 \mathrm{mR} / \mathrm{h} \text { at sur- } \\
\text { face of any waste } \\
\text { container }\end{array}$ & $\begin{array}{l}<3 \mathrm{mCi} \text { of }{ }^{35} \mathrm{~S}+<1 \mathrm{mCi} \\
\text { of other nuclides in } \\
\text { waste consigned per } \\
\text { month }\end{array}$ \\
\hline
\end{tabular}




\section{B. France}

\section{Cadarache Nuclear Study Center}

a. Incineration of Lou-Leuel Radioactive Wastes

Pretreatment of Wastes. Combustible wastes containing losv levels of radioactivity now being incinerated at Cadarache are composed almost entirely of paper, wood, rags, cotton, and graphite. These wastes are placed in $200 . /$ metal drums at the generating site. When full, the drums are collected and transported to the centrai treatment area where they are opened and checked for noncombustibles. The combustible wastes are then repacked in either polyethylene or paper bags.

Loading. The sorted solid wastes are introduced into the incinerator by means of a charging lock, and the liquid wastes are injected through a nozzle.

Incineration. After the wastes have been volatilized and oxidized in the main conbustion chamber $\left(1000-1100^{\circ} \mathrm{C}\right)$, the off-gases are oxidized further in a secondary chamber at temperatures similar to those in the main combustion chamber. Upon leaving the secondary combustion chamber, the gases enter an expansion chamber containing firebricks. Here entrained carbon particles may undergo further oxidation and, at the same time, cool along with the gases. From the expansion chamber the guses proceed into a cooling chamber. All four chambers are located in one unit that has a boxlikt exterior.

Off-Gas Cleanup. From the cooling chamber the gases exit into the off-gas cleanup train. Here the gases are cooled by air dilution to $\angle 2 n 0^{\circ} \mathrm{C}$ and then pass through a "spray" tower containing Kaschig rings. The $\mathrm{pH}$ of the spraying water is maintained between 7 and 8 . The cooled and washed gases are then reheated from 45 to $80^{\circ} \mathrm{C}$, routed through a prefilter of glass wool, an absolute filter, an induceddraft fan, and a chimney, where they exit to the ambient atmosphere (Fig. 6i).

Performance. The Cadarache incinerator has a throughput capacity of about $30 \mathrm{~kg} / \mathrm{h}$ for solid waste and $10 \mathrm{~kg} / \mathrm{h}$ for liquid waste. It usually operates in quarterly runs of 2- or 3-wk duration.

b. Modification for Incineration of PlutoniumContuminated Wastes. The fuel fabrication plant for the Rapsodie and Phenix reactors is located at Cadarache, so the amount of plutonium in

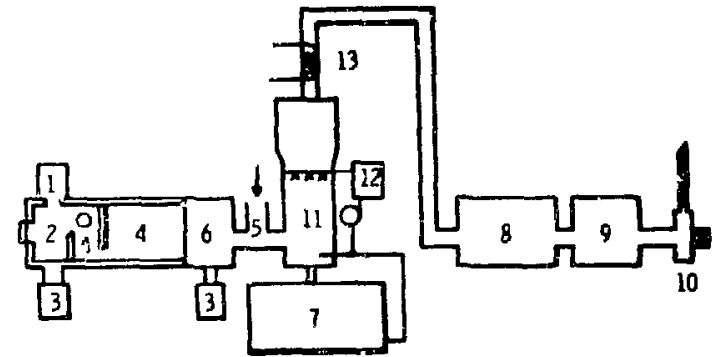

1. CHARGING

2. MAAIN COMBUSTION CHAMBER

3. ASH AND SOOT COLLECTION

4. POST COMBUSIION

5. DILUIION

6. COOLER

7. WASHING-WATER FILIER

Fig. 6.

Incinerator at Cadarache.

Cadarache wastes has increased in the lasi few years. About $80-90 \%$ of these plutoniumcont $a_{2}$ ininated wastes are combustible. A study is under way to determine the modifications necessary $t r$, enable the present incinerator to burn plutoniurncontaminated wastes. The study covers improvements in combustion processes so that ail nonmetallic wastes from the fuel fabrication plent can be incinerated, simplification of the treatment of gases released by the incinerator, and changes to insure that the ash-loading and removal stations are leakproof. In additicn, the amount of plastics used will be kepi to a minimum and PVC will be eliminated wherever possible because of the problems caused by chlorine during incineration.

\section{SOURCES}

A. Barbreatı, J. Marcaillou, J. Mery, D. Pinto, and D. Rancon, "Evolution de la Gestion des Dechets de Basse Activite et d'Activite Irtermediaire au Centre de Cadarache," in Proc. Symp. Developments in Management of Low- and Intermediate-Leve] Radioactive Wastes, Aix-en-Provence, September T11, 1970 (IAEA, Vienna, 1970), pp. 297-371.

J. Mery and J. Marcaillou, "Gestion des Dechets Solides Contamines per du Plutonium au Centre de Cadarcine," Proc. Seminar Management of Plutonium-Containing Solid Wastes, Marcoule Center, France, Octọer 14-16, 1974 (ERDA report CONF-741026), Paper 4. 
J. Pradel, P. J. Parsons, and E. Malasek, "The Volume Reduction of Low-Activity Solid Wastes," IAEA Technical Report Series No. 106 (1970), pp. 26-29.

\section{Fontenay-aux-Roses Center (CEN-FAR)}

Lou-Level Radioactive-Waste Incinerator. The CEN-FAR incineration system was placed in service in 1967. Since that time, there has been a steady increase in the types and quantities of radioactive wastes because of expanding activity in reactors, research in plutonium, irradiated fuels, and radiobiology. Radiosictive wastes at this facility include fission products and radioisotopes resulting from activation experiments.

The CEN-FAR incineration facility is operated mainly to minimize the volume of low-level wastes and to dispose of animal remains containing small amounts of radinnuclides. Any items that might cause an explosion are specifically excluded during sorting.

Loading System and Incinerator Design. In design, the incinerator is similar to the Cadarache facility. The charging lock for solids, liquid-waste fuel-injection nozzle, combustion- and expansionchamber design are similar. As at Cadarache, the grate of the first chamber can be tipped to permit discharge of the ashes into drums. Proper operating temperatures are maintained in thic combustion chambers by a conventional oil burner in the primary and a propane burner in the secondary. Also, the expansion chamber contains firebricks to increase oxidation of carbon black.

Off-Gas Cleanup. CEN-FAR uses a dry off-gas cleanup system. The gases exit the expansion chamber and are cooled to $350-400^{\circ} \mathrm{C}$ by air dilution before entering a cooler where they are further cooled in a tubular, air-cooled heat exchanger to $120-150^{\circ} \mathrm{C}$ to minimize the risk of fire. Next, they pass through a glass-wool bag filtei and a box of asbestos absolute filters.

Ash Removal. The bottom of each section of the system has a metal drum for collection of ashes and soot. The ashes are fixed by the addition of water and cement.

Performance. In 1969 the incinerator ran for 80 days, incinerating $5644 \mathrm{~kg}$ of animal remains and
$7411 \mathrm{~kg}$ of other wastes. The ash weighed $311 \mathrm{~kg}$. The installation is capable of treating $50 \mathrm{~kg} / \mathrm{h}$ of solid wastes and $15 \mathrm{~kg} / \mathrm{h}$ of contaminated liquids. A schematic is given in Fig. 7.

Problems. Two major problems have been encountered at the CEN-FAR facility. One problem involved cleaning tise absolute filter. It was necessary to stop loading the furnace for about $30 \mathrm{~min}$ while cleaning the absolute filter. To eliminate this problem, two filters have been placed in parallei so that one filter can be in use while the other is being cleaned. Moreover, to reduce stress on the bags, they are now cleaned by a countercurrent flow of air. Consideration has also been given to the replacement of the bag filter with a high-temperature, asbestosfilled filter, which would permit further combustion of carbon, as well as serving as a particulate collector. Because of the expense and downtime required for installation, this type of filter has not yet been installed.

Another serious problem has been corrosion. During the combustion of $\mathrm{PVC}, \mathrm{HCl}$ is released and reacts to cause corrosion in the cooling and cleaning system. Since ferric chloride is very hygroscopic, a solution now under consideration is to maintain a dry atmosphere in the incinerator during shutdowns.

\section{SOURCES}

J. Pomarola, P. Feliers, and G. Testemale, "Evolution de la Gestion des Dechets Radioactirs au Centre de Fontenay-aux-Roses," in Proc. Syrup. Developments in Management of Low- and Intermediate-Level Radioactive Wastes, Aix-enProvence, September 7-11, 1970 (IAEA, Vienna, 1970), pp. 537-562.

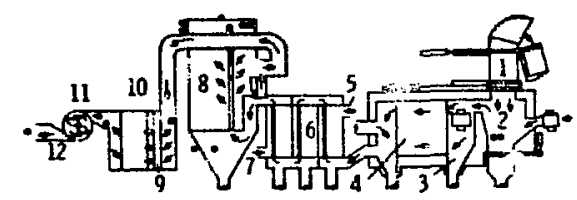

$\begin{array}{ll}\text { 1. CHARGING LOCK } & \text { 7. ENTRANCE OF COOLING AIR } \\ \text { 2. COMIBUSTION CHAMBER } & \text { 8. BAG FILTER } \\ \text { 3. SECONDARY COMBUSTION CHAMBER } & \text { 9. FILIER } \\ \text { 4. EXPANSION EHAMBER } & \text { 10. FILTER } \\ \text { 5. EXIT OF COOLING AIR } & \text { 11. FAN } \\ \text { 6. COOLER } & \text { 12. FLUE }\end{array}$

Fig. 7.

Incinerator at CEN-FAR. 
J. Pradel, P. J. Parsons, and E. Malasek, "The Volume Reduction of Low-Activity Solid W'astes," IAEA Technical Report Series No. 106 (1970), pp. 26-29.

\section{Nationai Center for Scientific Research (CNRS), Strasbourg-Cronenbourg}

Low-Level Radioactive-Waste Incinerator. In 1967 a special incinerator to burn wastes containing lowlevel radioactive material was designed for operation at Strasboury-Cronenbourg. Specifically, this in. cinerator was to burn wastes containing contaminated animal remeins. Its throughput is about $15 \mathrm{~kg} / \mathrm{h}$ of solid wastes and there is some capability for contaminated liquid wastes.

Predesign Studies. Before the incinerator was designed, a study was made of uperational radioactive-waste incineration systems. The following problems were identified in those systems.

(1) Plastics (especially PVC) heated to high temperatures generate large quantities of carboncontaining particles (soot) that become entrained in the combustion off-gases and can cause clogging and filter fires in the off-gas cleanup system.

(2) At high temperatures, plastics can become "sticky" and flow, thereby clogging the grate if the grate has small holes. If the grate does not clog, this plastic flow may not completely oxidize and volatilize and may run through the grate into the ash pit below. If the waste contains only a linited amount of plastic, these two problems may not be significant. However, extensive effort is necessary to presort and mix the xaste uniformly lest a large quantity of plastic in one charge be introduced into the incinerator.

(3) In addition to generating scot and causing a sticky mess, plastics, such as PVC, that contain $\mathrm{Cl}^{-}$ will produce $\mathrm{HCl}$ while undergning combustion, thus fostering severe corrosion. Therefore, in the Strasbourg-Cronenbourg incinerator, various techniques have been employed to eliminate or reduce these problems of corrosion and ivcomplete combustion. A schematic of this modified system is shown in Fig. 8.

Loading. The charging lock is such that the combustion chamber of the incinerator can never be in direct contact with the surrounding air. The airtight sliding doors, only one of which can be open at a time, serve the charging lock into which the waste is first intrnduced. Only after the first door of the lock is completely closed can the second door be

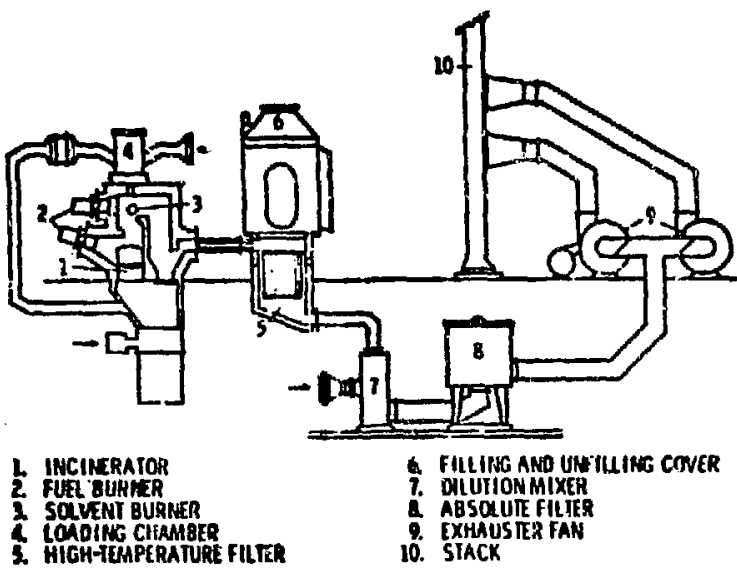

Fig. 8.

incinerator at Strasbuurg-Cronenbourg.

opened and the waste charged into the combustion chamber. The lock is constantly swept by a stream of ai- which, after removal of any dust, is fed into the incinerator to provide part of the oxygen necessary for the combustion process.

Inninerator Design. The incinerator, with an outer casing of oteel plate, has several refractorylined interior chambers. The first chamber into which the waste is introduced is the charging well. The upper part is closed by a shield which protects the charging lock against thermal radiation from the well and combustion chamber. The lower part of the well connects with the main combustion chamber.

The main combustion cluamber is a vertical chamber in which the waste undergoes the major part of its csmbustion. This chamber has two quartz viewing windows. The chamber is equipped with a swiveling poker for stirring wastes and cinders. The main combustion air is supplied from below the chamber and ascends through the chamber into the secondary or postcombustion chamber.

The grate system consists of a set of "stairs," constructed with a refractory steel frame. which begin at the lower part of the charging well. Any plastic waste introduced into the charging well melts and drips down these stairs. As the combustion air circulates between each step, the plastic oxidizes and thus does not get into the arh.

A horizontal retention plate of refractory steel is located in the lower part of the combustion chamber to insure final combustion of the liquid wastes. It is lowered for easy evacuation of the ash.

The incinerator has three burners. As shown in Fig. 8, item 3, a lurner for contaminated solvents is located near the top of the combustion chamber. A 
spray rozzle receives the solvents from a special tank under nitrogen pressure. Two burners, item 2 in Fig. $d$, maintain the proper operating temceratures. The lower burner maintains the temperature in the combustion chamber, and the upper burner, which is designed to give a very long flame, heats the secondary combustion chamber. These burners deliver premixed and atomized fuel to the chamber. A flame detector monitors each burner.

As the gases leave the nain combustion chamber and pass into the secondary or postcombustion chamber, an excess amount of air is included to promote further oxidation of hydrocarbon gases and entrained carbon particles. To promote oxidation, the postcombustion chamber contains a bed of rough silicon-carbide grains with a high surface-to-volume ratio. The lower part of the chanisber is closed by a rocking trap by which this silicon-carbide residue can be unloaded into a drum if the bed needs to be replaced.

The gases flew downward through i:e chamber and exit at $\sim 900^{\circ} \mathrm{C}$ into the off-gas cleanup train.

Off-Gas Cleanup. From the postcombustion chamber the gases flow to the high-temperature filter (Fig. 9) through a steel connector with expansion bellows.

The high-temperature filter set is the main unit used for uff-gas cleanup in this system. It is constructed of a steel frame lined with refractory. At the top is a steel plate from which hang candles made of microexpanded refractury steel lined with a filtration medium of disintegrated and thermally pretreater asbestos. The system completely stops any unburned carbon that has escaped the postcombustion chamber. The carbon is captured on the filter an 'u burns without affecting the filter's efficiency. The high-temperature filter also serves to prevent fires in the ahsolute filter and extends its lifetime.

A tight enclosure above the filter allows replacement of the asbestos filtration medium. The enclosure contains a winch for lifting the filter lid. Personnel must use one of two half-suits (Fig. 9) when working in this area.

Cleaned of most of the soot, the gases pass downward from the high-temperature filter through a chamber where air is added and mixed with the gas The gases leave this cooler at $150^{\circ} \mathrm{C}$ and pass through the absolute filter (composed of two cells) into the $10 \cdot \mathrm{m}$-high stack and out to the ambient atmosphere.

Ash Removal. The ashes are removed from the combustion chamber through use of a drum lirider

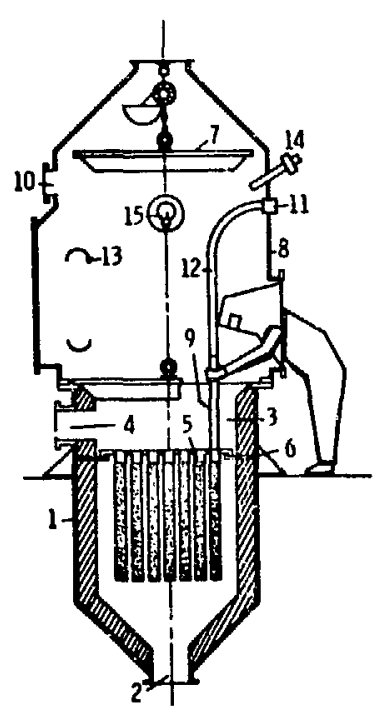

1. SHELL

2. OUTLET FOR GAS

3. DISTRIBUTION CHAMBER FGE GAS

4. INLET FOR GAS

5. STEEL TUBES

6. SUPPORT

7. 110

8. COVER
9. TUBE VACUUM CLEANER
10. VALVE
11. HANGER
11. HANG
13. WINDING UNIT FOR VACUUM CLEANER
14. HOSE UNION LEADING TO
15. LAMP

Fig. 9.

High-temperature filter of StrasbourgCronenbourg incinerator.

the ash hopper. In the case of $32 \mathrm{P}, \sim 86 \%$ of the activity remains in the ash.

Corrosion. Corrosion-resistant materials were used throughout the system. For example, all the ducts connecting the air-dilution system, the absolute filter, the fan, and the cnimney are constructed of glass or have an anticorrosion lining capable of withstanding a continous temperature of $150^{\circ} \mathrm{C}$ or a temperature of $200^{\circ} \mathrm{C}$ for short periods. The chimney is of polyester impregnated with glass fiber. Special steels of high chromium and nickel content (310) are used in the candles of the hightemperature filter.

Other anticorrosion measures are also taken. in the low-temperature part of the system, care is taken to maintain the temperature of the gases above the dew point. Air-dilution cooling was chosen because it reduces the concentration of water vapor and $\mathrm{HCl}$ in the cooled gases.

Safety. Safety features of this incinerator design include system alarm and regulation monitors for pressi!re, temperature, gas flame, etc. An auxiliary fan can be operated in the event of failure of the first fan. 
Performance. The incinerator began operating in Vovember 1970 . By January $1972,5800 \mathrm{~kg}$ of solid waste (70\% small animai bodies, $10 \%$ paper and egg shells, $20 \%$ various plastics) and 980 / of liquid waste had been incirierated, and $280 \mathrm{~kg}$ of ash had been produced.

\section{SOURCES}

Roger Delarue, Jacques Prade!, and Claude Teissier, "L'Incineration des Dechets Radioarcifs au Groupe de Laboratoires du C.N.R.S. a StrasbourgCronenbourg," Ind. At. Spatiales 16, No. 5, 53-64 (1972).

"High Temperature Filter for Hot Gases. C.E.C. System," Carbonisation Entreprise et Ceramique. Commissariat a l'Energie Atomique (CEA) patent.

\section{Marcoule Center of Plutonium Production, Bagnols-8ur-Ceze}

a. Low-Level Radioactive-Waste Incinerator. An incinerator for the volume reduction of low-level radioactive wastes has been in operation at the Marcoule Center since 1964 . The incinerator's capacity for solid wastes and oils burned together is 60-70 $\mathrm{kg} / \mathrm{h}$ of solid wastes and $20-25 / / \mathrm{h}$ of oil; for burning only oil, $50 / / \mathrm{h}$. The system is shown in Fig. 10.

Pretreatment of Wastes. Before the wastes are placed in the incinerator they are carefully sorted to remove any noncombustible or potentiaily explosive materials. The wastes are then mixed to provide a charge with a composition and heating value as uniform as possible before introduction into the incinerator. Moreover, to reduce corrosion in the incinerator, PVC has been replaced by polyethylene wherever possible so that a minimum of PVC is charged into the furnace. The charged wastes contain $80 \%$ polyethylene, $8 \%$ paper, $5 \%$ wood, and $7 \%$ miscellanecus materials.

Loading. The waste is hoisted to an automatic loader and charged into a double-doored lock chamber. The double doors are arranged to prevent direct contact between the furnace air and the outside air. The lock has independent ventilation which is regulated according to the pressure in the shop and that in the corsbustion chamter. Burners in the furnace allow for the introduction of cont minated liquids.
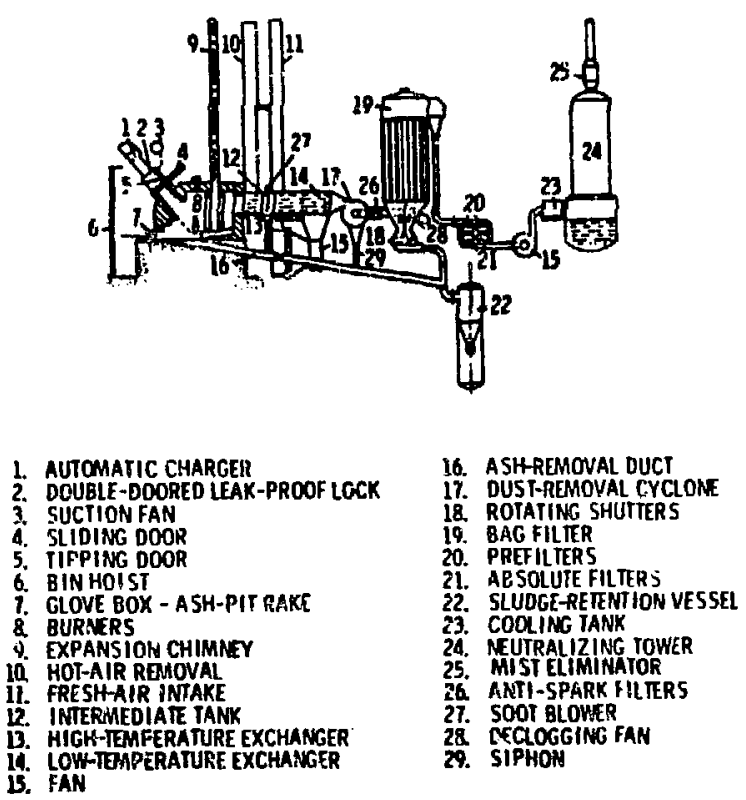

Fig. 10.

Incinerator at Marcoule Center.

Incinerator Design. The incinerator has three chambers: a main combustion chamber, a postcombustion chamber, and an expansion rhamber. The furnace is constructed of firebrick with a bridge-wall sepsrating the combustion chamber froin the postcombustion chamber. Propane burners maintain the proper temperatures in these two chambers: the temperature in the main combustion chamber is kept at $700 \cdot 1100^{\circ} \mathrm{C}$, and that in the postcombustion chamber at $\sim 1100^{\circ} \mathrm{C}$. A safety release system is maintained in the furnace in case of an explosion. From the postcombustion chamber, the hot gases pass into the expansion chamber where they are further oxidized.

Cooling and Off-Gas Cleanup. From the expansion chamber, gases pass into the air-to-air cooing system. Cooling oscurs in two stages: from 1000 $400^{\circ} \mathrm{C}$ and from $400-150^{\circ} \mathrm{C}$. Tube cleanliness, imperative for prope: heat transfer, is maintained by automatically sweeping the tubes with compressed air. The tubes can also be cleaned by brushing.

After the gases have cooled to $150^{\circ} \mathrm{C}$, they pass through a preseparator cyclone which removes most dust particles of $>10-\mu$ diam. From the cyclone the gases pass through antispark filters, each composed of a thick layer of stainless-steel wire netting. 
The gases are cleaned further in a baghouse containing 32 glass-fiber bags impregnated with graphite and having compartments. The bags are atiogged automatically by successive suction and blowing operations. The baghouse is $\sim 98 \%$ efficient in removing particles of $>1-\mu$ diam, and $\sim 90 \%$ efficient for particles of $0.3-\mu$ diam.

Next, the gases pass through prefilters and absolute filters before being drawn by a fan into the cooling tank. The absolute filters are made of folded glass paper and are $99.97 \%$ efficient in removing particles with an average dianieter of $0.3 \mu$. The fan system consists of two parallel fan-blowers, one of which is always on standby. The steel voiute is covered by plastic. Gases are cooled from $120-60^{\circ} \mathrm{C}$ in the cooling tank, which is made of mild steel with an interior lining of Hypalon.

The gases then pass through a neutralization column where any acid gases are neutralized by a countercurrent flow of liquid maintained at a pH of 9 by the addition of sodium. This sodium solution is resycled in order to minimize the quantity of liquid effluent. Finally, the gases pass through a mist eliminator and are discharged through the stack.

The performance of this rather complex gas cleanup train is summarized in Table II. Note the importance of the bag filter in reducing the load, hence increasing the lifetime of the absolute filter.

Ash Removal. Ashes can be removed through a channel (wet method) or through use of a glove box

TABLE II

\section{EFFICIENCY OF STAGES OF GAS CLEANUP TRAIN} AT MARCOULE CENTER'S INCINERATOR

\begin{tabular}{|c|c|c|c|}
\hline \multirow[b]{3}{*}{ Stage } & \multicolumn{3}{|c|}{ Retention (\%) } \\
\hline & \multicolumn{2}{|c|}{ Radioactivity } & \multirow[b]{2}{*}{ Mass } \\
\hline & Alpha & $\begin{array}{c}\text { Beta/ } \\
\text { Gamma } \\
\end{array}$ & \\
\hline Cyclone & $48-53$ & 10 & 10 \\
\hline Bag filter & $\begin{array}{l}98.8- \\
99.7\end{array}$ & $\begin{array}{l}98- \\
99.5\end{array}$ & $\begin{array}{l}97- \\
98.5\end{array}$ \\
\hline $\begin{array}{l}\text { Absolute } \\
\text { filter } \not \\
\text { neutrali- } \\
\text { zation } \\
\text { column }\end{array}$ & 90 & $98-99$ & $\begin{array}{l}\text { Non- } \\
\text { measurable }\end{array}$ \\
\hline
\end{tabular}

fitted with a rake. The ashes can be treated with asphalt to reduce the possibility of leaching.

Performance. The incinerator is on line $20-22 \mathrm{~h} /$ day. Radioactivity measurements have been made throughout the system during the incineration of 167 $\times 10^{3} \mathrm{~kg}$ (184 tons) of solid waste and $154 \times 10^{3} \mathrm{~kg}$ (170 tons) of oil. The results are given in Table III. Plutonium was completely retained in the ashes and soot, whereas a small amount of uranium was carried over into the neutralization tower. The presence of uranium in the tower effluents was attributed to simultaneous combustion of flucrinecontaining compounds that formed uranium hexafluoride which passed through the filters and decomposed in the neutralization column.

\section{SOURCES}

G. Wormser, J. Rodier, E. de Robielı, and N. Fernondez, "Ameliorations Apportees aux Traitements des Residus Radioactifs," in Proc. Intern. Conf. Peaceful Uses At. Energy, 3rd, Geneva, 1964 (United Nations, New York, 1965), Vol. 14. pp 223-224.

J. Pradel, P. J. Parsons, and E. Malasek, "The Volume Reduction of Low-Activity Solid Wastes," IAEA Technical Report Series No. 106 (1970), pp. 25-26.

J. Rodier, G. Lefillatre, and R. Estournel, "Incineration Industrielle des Dechets Radioactifs Bilan Technique et Financier," in Proc. Symp. Practices in Treatment of Low- and Intermediate-Level Radioactive Wastes, Vienna, December 6-10, 1965 (IAEA, Vienna, 1966), pp. 663-685.

Y. Sutra-Fourcade, B. Caire, and F. Gallissian, "Dust Separation of Combustion Gas in a Radioactive Residue Incinerator," in Symp. Experience Gained and Progress in Treatment of Radioactive Aerosols, New York, August 26-30, 1968, IAEA report SM 110/12.

b. Pilot Incinerator for Plutonium-Contaminated Scrap. Activities at Marcoule, such as reprocessing of irradiated fuels, plutonium fabrication, and research on plutonium chemistry, produce waste materials contaminated with high levels of plutonium. Materials commonly found in this category are PVC, latex, cotton, and absorbent paper. It was thought at Marcoule that incineration 
TABLE III

\section{DISTRIBUTION OF RADIOACTIVITY IN THE MARCOULE INCINERATION SYSTEM}

\begin{tabular}{|c|c|c|c|c|c|}
\hline \multirow[b]{2}{*}{ Source } & \multirow[b]{2}{*}{ Amount } & \multicolumn{2}{|c|}{ Alpha-Emitters } & \multicolumn{2}{|c|}{ Beta-Emitters } \\
\hline & & $\begin{array}{c}\text { Total } \\
\text { Activity } \\
\text { (mC) }\end{array}$ & $(\%)$ & $\begin{array}{c}\text { Total } \\
\text { Activity } \\
\text { (mCi) } \\
\end{array}$ & (\%) \\
\hline $\begin{array}{l}\text { Ashes with } \\
15 \% \text { water }\end{array}$ & $8247 \mathrm{~kg}$ & 2684 & 99.6 & 2296 & 94.3 \\
\hline Sludge & $79.5 \mathrm{~m}^{3}$ & & 0.4 & & 5.7 \\
\hline $\begin{array}{l}\text { Effluents from } \\
\text { neutralization } \\
\text { column }\end{array}$ & $24.0 \mathrm{~m}^{3}$ & $2.10^{-4}$ & & 12 & \\
\hline Chimney reject & $3.8 \times 10^{7} \mathrm{~m}^{3}$ & $3.4 \times 10^{-4}$ & negligible & 11 & negligible \\
\hline
\end{tabular}

of the combustible wastes would not only reduce their volume but at the same time would permit zecovery of the plutonium from the ash. A pilot incineration plant with a capacity of $\sim 1 \mathrm{~kg} / \mathrm{h}$ was put in operation at the Marcoule Center in 1970 (Fig. 11). This unit operated for 2 yr on "cold" waste before baing used to burn the plutoniumcontaminated wastes produced at the various sites. About $42 \%$ of the waste is rubier; $51.3 \%$, PVC; and $5.7 \%$, cellulose.

Pretreatment of Wastes. The contaminated wastes are presorted and sacked into $150-\mathrm{mm}$-diam

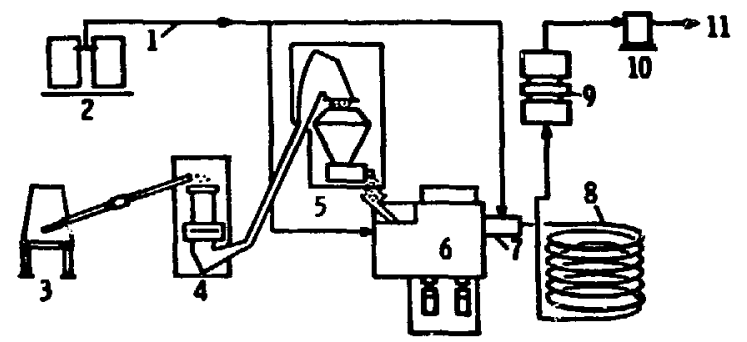
1. AIR
2. DRIER
3. SORTING
4. GRINDER
5. RATE-SETTING HOPPER
6. FURNACE
7. MIXER
8. COOLRR
9. FIIIERS
10. FAN
11. PURIFIED GASES

Fig. 11

Pilot incinerator at Marcoule Center.
PVC bags and stored in drums until they are charged to the incinerator system. The sacks of waste are introduced into the system through a glove box, are passed in front of a metal detector, and if no metal is detec sed they are routed to a shredder, where they are reduced to confetti-sized pieces in a nitrogen atmosphere. From the hopper where they land after shredding, the wastes are transferred by conveyor belt to the storage hopper located in the supply glove box of the furnace.

Loading. The wastes are taken from the storage hopper and by means of an endless screw are passed to a water-jacketed, vertical drop-pipe which leads to the incinerator. (Should the wastes ever ignite, the feed system will stop and $\mathrm{CO}_{2}$ will be released to quench the fire. This safety system has never been needed.)

Incinerator Design. The incinerator is made of a single block of refractory concrete cast in place and covered by a leakproof metal housing to contain alpha activity. The first chamber, which receives wastes through the drop-pipe, is heated electrically to $\sim 700^{\circ} \mathrm{C}$. A horizontal flue, terminating under the vault of this chamber, provides dry, preheated $\left(300^{\circ} \mathrm{C}\right)$ air.

From the main combustion chamber the gases pass into the afterburner. This section is formed by three vertical flues arranged as baffles. Each f? contains two silicon-carbide liners carrying electrical 
heating resistors that maintain the temperature at $1100^{\circ} \mathrm{C}$.

Cooling and Off-Gas Cleanup. As the gases leave the afterburner, they are diluted and cooled to $300^{\circ} \mathrm{C}$ by mixing with cool, dry air and then are further cooled (to $<60^{\circ} \mathrm{C}$ ) by passing through a water-cooled heat exchanger. After leaving the cooling system, the gases pass through double filters, through the fan system, and into the stack for release to the atmosphere. Gaseous chlorine compounds, such as $\mathrm{HCl}$, are not removed in the off-gas cleanup train because the throughput of the incinerator system is considered to be so small that the chlorine compounds do not produce a hazard.

Ash Removal. For the main-combustion furnace unic, a trap screen provides access to a handoptrated rabble which is used to push the ashes into a refractory hopper. In the arterburner section, the first flue has an ash hopper at its base, and the other two flues share a second ash hopper.

The ashes can be emptied, through use of valves, into metal containers. This is done in a glove box fixed under the incinerator. The ashes are then stored until they can be sent for plutonium recovery.

Distribution of Ash and Plutonium. During incineration of $7313 \mathrm{~kg}$ of wastes containing about 7483 $\mathrm{g}$ of plutonium, a study of ash distribution in the system gave the following results.

\begin{tabular}{lll}
\multicolumn{1}{c}{ Origin of Ash } & wt\% \\
\cline { 1 - 1 } Main combustion chamber & & 95.5 \\
Postcombustion chamber & & 2.1 \\
Air-dilution unit & 0.5 \\
Water-cooled heat exchanger & 0.4 \\
Filters & 1.5
\end{tabular}

The type of compound deposited varied in different parts of the system. For example, condensed volatiles, including $\mathrm{FeCl}_{3}$, were found in the airdilution system. In the filters, much of the matter was $\mathrm{ZnCl}_{2}$. The plutonium in the filter deposits constituted $\sim 0.2 \%$ of the total deposit, whereas the plutonium in the ash from the main combustion chamber constituted $\sim 3.4 \%$.

It is estimated that $>90 \%$ of the plutonium in the material fed to the incinerator is sent for recovery, but uncertainties about the plutonium content in the wastes and ash make this percentage uncertain. Nevertheless, it is evident that not much plutonium is retained in the furnace.
Problems. Several problems have arisen in the operation of this pilot-plant incinerator. The hopper/screw conveyor in the waste-loading system has not workea satisfactorily. In addition, the vertical feed-pipe plugged up gradually as softened particles accumulated on the walls, making necessary the installation of a slowly rotating, electrically controlled rabble to facilitate cleaning.

In the furnace itself, the refractory concrete is still intact, and the flooring has no visible cracks. The refractory stainless-steel claddings and the baffle have resisted corrosion. Two of the ten electrical resistance wires have been changed, and one of the silicon-carbide liners has been replaced.

The ash pits and wells have plugged up. It would be better to collect the ashes in containers having the same cross section as the furnace outlet. In the water-cooled heat exchanger a crack in the temperature-resistant stainless steel was detected after $2.5 \mathrm{yr}$ of operation.

Chlorides have volatilized in the pilot system. The wastes contain traces of iron, zinc, cadmium, lead, copper, and molybdenum which can unite with the chlorine to form gaseous chlorides (see Table IV). These chloride compounds may deposit in the cool portions of the systems, such as the heat exchanger, filter, and exhaust pumps. Because of entrained soot and condensable chlorides, the absolute filters are currently requiring replacement as often as every 1 or 2 wk.

c. Incinerator for Plutonium-Contaminated Wastes. A larger incinerator, designed for a $10-\mathrm{kg} / \mathrm{h}$ throughput, will be built at Marcoule. It is hoped that many of the problems experienced with the pilot facility will not occur with the new facility. For

TABLE IV

\section{BOILING POINT OF SOME CHLORIDES}

\begin{tabular}{lcc}
\cline { 1 - 1 } Chloride & & $\left({ }^{\circ} \mathbf{C}\right)$ \\
\cline { 1 - 1 } & & \\
$\mathrm{Cl}_{2} \mathrm{Fe}$ & & 670 \\
$\mathrm{Cl}_{3} \mathrm{Fe}$ & & $285-315$ \\
$\mathrm{Cl}_{5} \mathrm{Mo}$ & & 268 \\
$\mathrm{Cl}_{2} \mathrm{Zn}^{\mathrm{a}}$ & & 732 \\
$\mathrm{Cl}_{2} \mathrm{~Pb}$ & & 950 \\
$\mathrm{Cl}_{2} \mathrm{Cu}$ & & 993
\end{tabular}

${ }^{a} \mathrm{Cl}_{2} \mathrm{Zn}$ may sublime and its vapor pressure will be high long before its boiling point is reached. 
example, the hopper/screw conveyor system is being completely redesigned. High temperatures will be maintained in the off-gas cleanup system in order to reduce corrosion. A high-temperature filter system similar to the one at Strasbourg-Cronenbourg will be installed for soot removal.

Improvements in automation are also anticipated for the sorting and feeding systems. Such improvements should lower the present operator dose exposure of about $70 \mathrm{mRem} / 100 \mathrm{~kg}$ of incinerated waste.

A diagram of the full-scale facility is given in Fig. 12.

\section{SOURCES}

C. Lefevre, "Incineration pour la Recuperation du Plutonium dans les Dechets Combustibles," in. Proc. Symp. Developments in Management of Low- and Intermediate-Level Radioactive Wastes, Aix-enProvence, September 7-11, 1970 (IAEA, Vienna, 1970), pp. 657-668.

J. M. Auchapt, "Etude du Procede de la Technologie et du Comportement en Routine de l'Incinerateur Alpha de Marcoule," Proc. Seminar Management of Plutonium-Contaminated Solid Wastes, Marcoule Center, France, October 14-16, 1974 (ERDA report CONF-741026), Paper 13.

H. Soulier, "Incinerateur de Rechets Riches en Emetteurs Alpha de Marcoule Fonctionnement," Froc. Seminar Management of Plutonium-

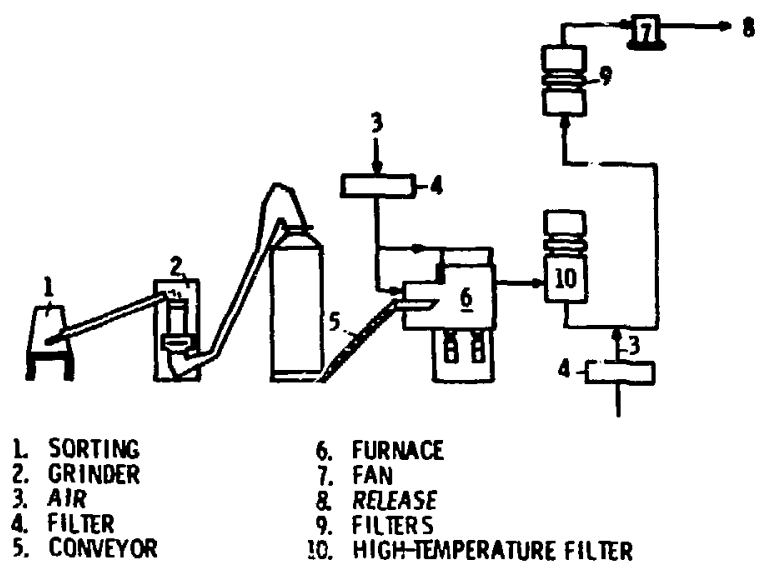

Fig. 12.

Incinerator to be built at Mar oule Center.
Contaminated Solid Wastes, Marcoule Center, France, October 14-16, 1974 (ERDA report CONF. 741026), Paper 14.

\section{Center of Nuclear Studies, Grenoble (CEN- G)}

a. Pilot System Used in the 1960's. A small $(8 \cdot \mathrm{kg} / \mathrm{h}$ throughput) pilot incineration plant was placed in operation at CEN-G in 1961 specifically to incinerate biological wastes and other organic radioactively contaminated wastes. About $400 \mathrm{~kg}$ of annual throughput was reported for this incinerator in 1964 .

The off-gas cleanup system was designed with a cyclone and scrubber (with a recirculating water spray) in series. Decontamination factors for this cleanup train varied between 50 and 100; however, they were considered adequate because of the small amount of radioactivity in the wastes fed to the incinerator $\left(\sim 10^{-9} \mathrm{Ci} / \mathrm{g}\right)$.

By 1964 no serious corrosion had been observed in the system. From the limited data available, this simply may reflect the lack of significant quantities of PVC in the waste materials.

b. Current Facility. The present CEN-G incinerator is being used for treatment of combustible wastes contaminated with beta- and gamma. emitting redionuclides. These wastes are composed of plastics, paper products, gloves, small animals, and solvents.

The incinerator consists of a primary combustion chamber and a secondary chamber; the latter operates at $\sim 1200^{\circ} \mathrm{C}$.

The high-temperature filter, which operates at $700-800^{\circ} \mathrm{C}$, is similar to the one at StrasbourgCronenbourg. Soot in the off-gases deposits on the candles in the filter and burns. Additional air is introduced in the next step to lower the temperature to $\sim 140^{\circ} \mathrm{C}$ before the gases pass through the absolute filter and then to the atmosphere.

Most of the activity from the waste is found in the ashes; the rest is trapped on the filtrating medium of the high-temperature filter.

\section{SOURCES}

G. Wormser, J. Rodier, E. de Robien, and N. Fernandez, "Ameliorations Apportees aux Traitements de Residus Radioactifs," in Proc. Intern. Conf. Peaceful Uses At. Energy, 3rd, Geneva, 1944 (United Nations, New York, 1965), Vol. 14, pp. 219-117. 
A. Lumongi, Center of Nuclear Studies, Grenoble, written communication, 1975.

\section{Belgium}

1. Belgium Nuclear Center, Mol (CEN). A waste disposal department for the treatment of liquid and solid radioactive wastes criginating from CEN, as well as wastes from EUROCHEMIC and other nearby facilities, is operated at CEN. Treatment of solid residues includes incirieration of some of the combustible wastes.

a. Incineration in the 1960 's. Incineration of radioactive wastes began at CEN in the early 1960's. At that time the maximum incinerating capacity was $200 \mathrm{~kg} / \mathrm{h}$. Activity of the presorted combustible waste material accepted for incineration cuuld not exceed $200 \mathrm{mR} / \mathrm{h}$ on the surface of all containers, and plutonium was supposed to be excluded. The waste was incinerated by batches. Actual operating time was a few hundred hours per year. Solid wastes were stored in polyethylene bags in concrete pits, and animal remains were placed in cold storage until incineration.

Loading. As the wastes were removed from temporary storage, they were monitored and then fed to the furnace. The charging lock closest to the furnace had water-cooled walls.

Incinerator Design. The furnace consisted of a block containing three chambers. The first chamber was used to incinerate combustible filters, the second to incinerate other wastes, including animal remains, and the third functioned as an afterburner. The furriace was lined with refractory bricks, and a refractory brick wall separated each chamber. Communicating holes allowed the gases to flow from one chamber to the next.

A large charging lock was required in the first chamber in order to charge the fiiters into this chamber. Two propane-gas burners, one above and one below the grate, were used to maintain the proper temperature. Air for combustion entered close to the grate. Scrapers in the furnace helped to maintain combustion and to evacuate the ashes through a funnel into a drum.

Plastic-bagged wastes were introduced into the second chamber through a lock. This chamber also had a grate, and ash removal was similar to that in the first chamber. Combustion air came from the first chamber.
The gases from chamber une passed through chamber two into the third or postcombustion chamber where further oxidation of residual tars. oils, and soot occurred. The gases then exited this chamber at $900^{\circ} \mathrm{C}$.

Off-Gas Cleanup. Several types of off-gas cleanup trains were tried. The system had to cope with large quantities of carbon black and acid gases if PVC and rubber were incinerated, and a great deal of effort was spent trying to eliminate these residues.

During operation of an electrostatic precipitator, the efficiency of the unit increased as the gas velocity decreased (to be expected) and as the humidity of the gas increased. Therefore, in the final design for the cleanup train, vaporized water was used to cool the gases (air dilution would have greatly increased the volume of gases to be treated).

In the final system, gases were cooled in a watercooled, double-enveloped washing tower. Further cooling occurred and coarse particles were washed out in an expansion chamber. A scrubber vessel with a bed of ceramic spheres provided additional gas cleanup, and a final scrubber vessel with a stack of Raschig rings removed the finer particles. Next, an electrostatic precipitator removed acid mist and particulates, while a final filter provided for further particulate removal. A collector and treating reservoir system for condensed liquids was included in which liquid was cleaned (using prefilters and sand filters), cooled, and neutralized to maintain a $\mathrm{pH}$ of 7.2 .

Ash Removal and Activity Retention. Ash was collected from each chamber and treated with asphalt to make the material insoluble. During testing of the incinerator, a given amount of a radionuclide was included in the waste. For $1: 31,7$, of the activity escaped in the off-gas, while for ${ }^{24} \mathrm{Na}$, $10 \%$ escaped in the off-gas.

Problems. The greatest problem was corrosion. It was necessary to watch closely the temperature and $\mathrm{pH}$ of the liquor in the system, and when the system was not in operation a phosphate solution was circulated regularly (about $1 \mathrm{~h} /$ day) through the system. During the last 3 yr of operation, costs rose steadily because of major overhaul and repair expenses resulting from corrosion problems in the gascleaning system.

b. Pilot Incinerator. In 1970 a new $10-\mathrm{kg} / \mathrm{h}$ capacity incinerator replaced the older unit and was designed as a research facility for studying solutions to various incineration problems. The experience 
gained from this facility will be used in the design and construction of a full-scale industriai plant.

Loading. Waste material is fed to the furnace through a lock system. Proper temperatures are maintained in the furnace by tangential-fired, propane-gas burners.

Off-Gas Cleanup. The gases exit the fumace into a cyclone operated at $900^{\circ} \mathrm{C}$ where the coarse particulate is removed. From the cyclone, the gases pass to an air-cooled hea: exchanger for cooling to $\sim 400^{\circ} \mathrm{C}$. They then pass through a sand filter, a wet cleanup system, an induced-draft fan, and a mist eliminator before exiting into the stack.

Ash Removal. The ashes are evacuated through a tilting grate toward a central collector for the final processing which consists of insolubilization in bitumen.

c. Molten Slag Incinerator. In addition to studying the incineration of wastes in order to produce a dry ash, the staff at CEN has also been studying the production of a molten slag residue using the FLK system. In this system, high temperatures are maintained in a small area. The molten slag is used to insulate the system. The faster the molten slag is produced, the faster new material moves into the reaction zone. Combustion air enters from above, while off-gases exit from the slag hole in the bottom.

\section{SOURCES}

N. Van de Voorde and E. Hoffmann, "Gestion de la Station de Traitement des Dechets Radioactifs a Mol," in Proc. Symp. Practices in Treatment of Low- and Intermediate-Level Radioactive Wastes, Vienna, December 6-10, 1965 (IAEA, Vienna, 1966), pp. 527-568.

J. Pradel, P. J. Parsons, and E. Malasek, "The Volume Reduction of Low-Activity Solid Wastes," IAEA Technical Report Series No. 106 (1970), pp. 28-29.

N. Van de Voorde, G. E. Cantillon, Ch. de Raikem, E. Detilleux, and H. Spriet, "Low. and Intermediate-Level Radioactive Waste Management in Belgium, in Particular at Mol," in Proc. Symp. Developments in Management of Low- and Intermediate-Level Radioactive Wastes, Aix-enProvence, September 7-11, 1970 (IAEA, Vienna, 1970), pp. 433-459.
G. Dumont, Head, Solid Waste Disposal Section, Belgonucleaire, personal communication, 19 'i5.

P. Dejonghe R. Lopes Cardozo, A. Tacymans, and N. Van de Voorde, "Incineration of Radioactive Solid Waste," Final Report No. 2, Pt. 2, Afril 1, 1961-March 31, 1963, EURAEC-697.

\section{Portugal}

1. Sacavein Center. The Sacavein Center is the largest producer of radiuactive wastes in Portugal and will be the site of a national waste-treatment station. Because of the Center's limited storage facilities, incineration will be used for those combustible wastes contaminated with a small amount of radioactivity.

Plans for the incineration urit iriclude a $25 \cdot \mathrm{kg} / \mathrm{h}$ capacity incinerator equipped with a barred grate and a rocking plate designed for the incineration of small animal bodies. The off-gas cleanup train will consist of a cyclone and dry filters.

\section{SOURCFS}

A. O. de Bettencourt and F. P. C. Segueira, "La Gestion des Dechets Radioactifs a la Commission de l'Energie Nucleaire du Portugal," in Proc. Symp. Developments in Management of Low- and Intermediate-Level Radioactive Wastes, Aix-enProvence, September 7-11, 1970 (IAEA, Vienna, 1970), pp. 57.68.

A. O. de Bettencourt, Nuclear Laboratory, Sacavéin, written communication, 1975.

\section{E. Republic of Germany}

1. Nuclear Research Center, Kas laruhe. About $60 \%$ of the solid radioactive wa: 3 at Karisruhe are combustible and consist of plastics $(\sim 30-50 \%)$, paper, filter material, rubber, wood, textiles, and animal remains. Almost all the radionuclides are present, and $\sim 7 \%$ of the waste contains plutonium. Most of the wastes are of low activity.

a. Incineration (1963-1970). A pilot incineration unit was built in 1963 to study the problems associated with the incineration of radioactive wastes having different beating values and containing large quantities of plastics, including PVC. High-level wastes were excluded, and any wastes 
containing large quantities of moisture were predried.

Loading and Incinerator Design. The furnace (Fig. 13) was a long cylinder with a conical recess at the bottom. Any bulky wastes were cut or otherwise reduced in size so thet all waste could be packed in $\leq 30-/$ plastic bags which were charged into the top of ine furnace through a lock. Coarser isaterial remained at the recess between the cylinder and cone sections. After some buning, this material would drop and joir the uner material for further burning on the grate. Initially, the ash contained a large amount of unburned material; however, after some experimentation, ash containing a small amount of unburned material was produced when increased amounts of air were introduced into the chamber.

The chamber was preheated to $\sim 200^{\circ} \mathrm{C}$ by air heated electrically to $\sim 600^{\circ} \mathrm{C}$. Readily combustible material was charged until the furnace reached its operating temperature of $900-1100^{\circ} \mathrm{C}$. The electrical air-preheating system was then switched off and the furnace was charged at a rate that permitted the prop $r$ temperature to be maintained. During nor- mal operation, air passed into the furnace from two points at the bottom.

Modifications to the fi mare unit included reinforcing the blickwolk is a $500-\mathrm{mm}$ thickness. Metal pipework wes vovered with brick to lessen corrosion, asid in other areas structural steel was substituted for alloyed steels. Some slag was deposited on the furnace walls, but was easily removed with an iron rod.

Off-Gas Cleanup. "'he off-gas cleanup system also underwent several modifications. At first, the system consisted of a tubular cooler, a bag filter, a fine filter, an induced-draft fan, and the stack. During startup, incomplete combustion in the furnace caused embers to be swept along into the bag filter. Soot that was caught on the bag filter ignited and caused a fire there. The filter container then had to be pushed off and another one used. To correct this problem, a surge chamber was installed between the furnace and tubular cooler. No further tires occurred, except in cases of negligence by operating personnel.

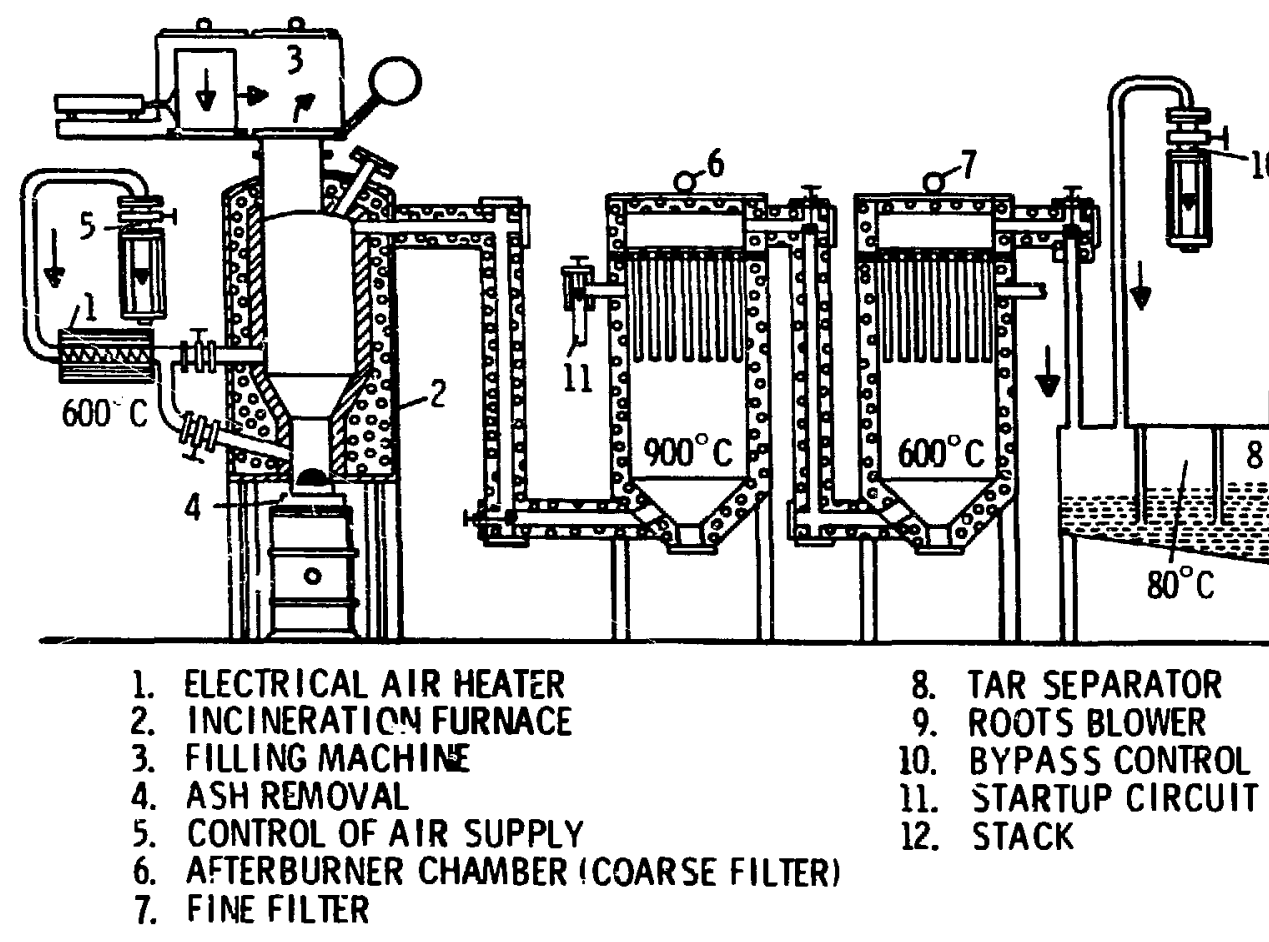

Fig. 13.

Incineration system at the Nuclear Research Center, Karlsruhe, after installation of candle filters. 
The cleanup system had additional problems. Tars and dust that condensed on the tubular cooler had to be removed periodically. Dust that collected on the bag filter required shaking of the bags several times each hour. (Filter bags had lifetimes of only 34 days.) Major corrosion was not found in the system because the temperature in most areas was above the dew point of the acid gases, but the dust collectors below the coolers were corroded by the acid fumes which condensed when the unit was down. To solve these problems, the gas cleanup system shown in Fig. 13 was installed.

After leaving the furnace, the gases went through a coarse "candle" filter and a fine "candle" filter, then through a tar separator, and finally through the induced-draft fan to the stack. The coarse candle filter consisted of a refractory-lined chamber at the top of which were 49 silicon-carbide filter candles suspended from a cast-irol plate. This filter was installed in duplicate so that one unit could be on standby. The urburned particles from the furnace deposited and burned on the coarse-grained candles and the ash flaked off the candles into an ash can. During startup, the candles were preheated to $>400^{\circ} \mathrm{C}$. During operation, the temperature in the coarse filter was $900^{\circ} \mathrm{C}$. The fine-filter chamber operated at $600^{\circ} \mathrm{C}$ and was similar to the coarsefiter chamber except that the candles were finer grained.

At first, there was a problem with clogging in the coarse filter because the candles were not heated to $>400^{\circ} \mathrm{C}$ quickly enough on system startup. This was overcome by preheating the chamber to the required temperature. There were also problems with the filters, which were made of two elements and which would tear at the joint. This situation was improved by modifying the fabrication method and by using a suitable adhesive. After these problems were overcome, a candle in the prefilter had a lifetime of $\sim 4$ wk, and a candle in the fine filter lasted -3 months. Improvements in candle design and fabrication have continued.

At the time that the candles were installed. consideration was also given to installing a wet systen. However, the wet purification system was abandoned because the candle filters gave good service, and a wet system would have produced a potentially corrosive, radioactively contaminated liquor.

Containment. In the early days, the operation room occasionally became contaminated. This problem was corrected by improving the methods used to introduce and discharge wastes. Another early problem was the occasional introduction into the system of highly reactive materials, thereby causing discharge through the burst disks.

Ash Removal. The ashes were dropped through a revolving grid into a $200-/$ drum flar,ed below the furnace. When the drum was $\sim 80 \%$ full, the ash was bound by mixing it with thin cement.

b. Incirieration (1971). The amount of radioactive wastes constantly increased with time until the pilot plant could not handle all the combustible lowlevel wastes. Therefore, a larger incinerator was built at Karlsruhe.

Pretreatment of Wastes. In the new facility, presorted wastes are received in plastic bags or fiberboard drums. Wastes too large to be placed in the feed air lock are crushed to a suitable size in a crushing hood and are then placea in fiberboard drums.

Incinerator Design and Off-Gas Cleanup. The new incineration plant can handle a throughput of $50.70 \mathrm{~kg} / \mathrm{h}$. The furnace design is similar to that of the piot plant but, of course, the furnace is larger. The off-gas cleanup train also is similar to that used in the pilot plant, except that the coolingcondensation vessel has been removed and the air from the filters is diluted with ventilation air from the building. The flow scheme is given in Fig. 14, and operating data are in Table V.

TABLE $V$

DATA FOR CURRENT KARLSRUHE INCINERATOR

Operating Temperature

Furnace

Coarse filter

Fine filter

Gas effluent

Measurements

Burning Zone

Afterburning zone

Operating Data

Burning capacity

Air requirements

Compaction factor

Vacuum

$\left.\quad{ }^{\circ} \mathrm{C}\right)$
1000
$900-1000$
600
250

(mm)

1000 (width)

3000 (height)

1000 (width)

2500 (height)

$70 \mathrm{~kg} / \mathrm{h}$ (nominal)

$750 \mathrm{~m}^{3}$

1-90

$490 \mathrm{~Pa}$ 


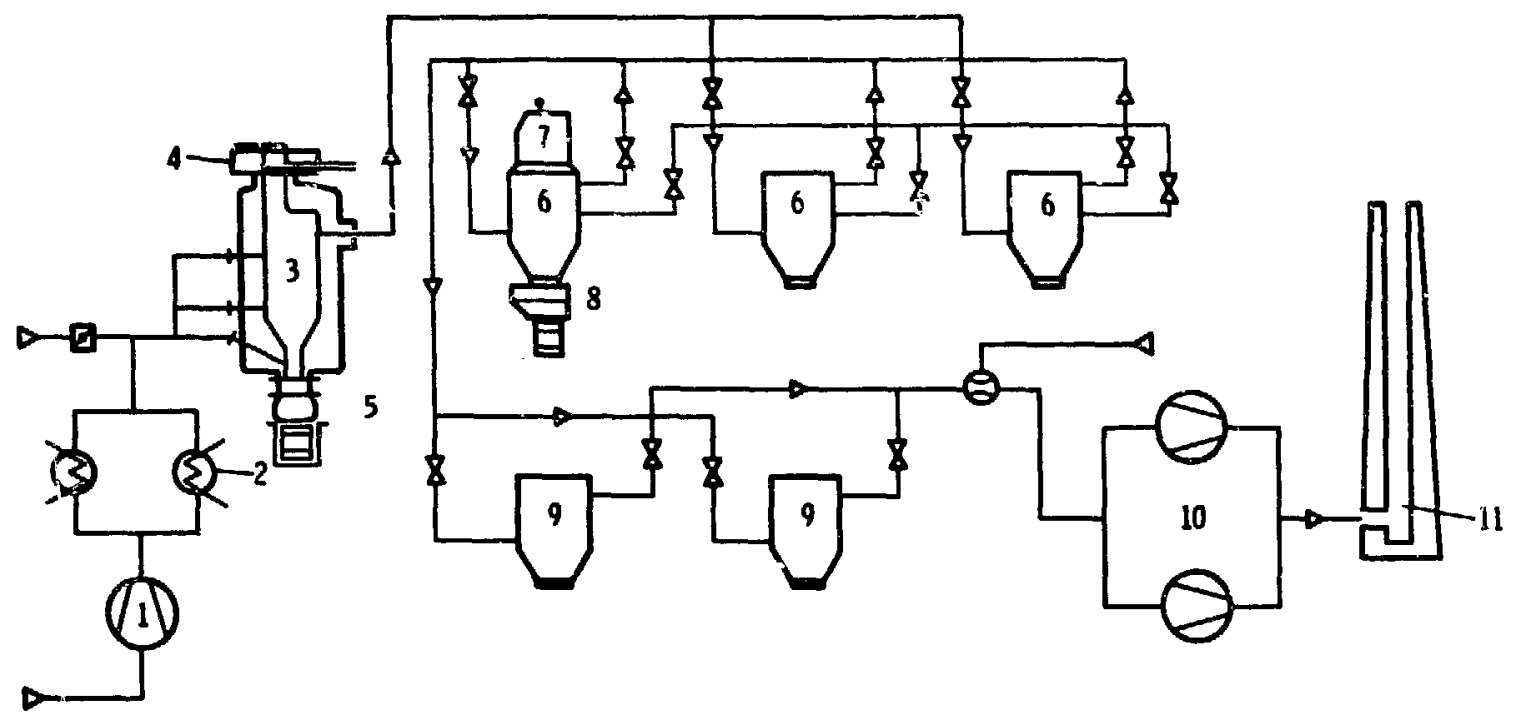

1. Air blower

2. Air preheater

6. Coarse filter

3. Incinerator

7. Filter change box

4. Rolary feed air lock

5. Ash lock ash drum, and lead shield

8. Ash-removal hood

9. Fine filter

10. Suction fan

11. Stack

Note: Newty installed scrubber is not shown.

Fig. 14.

Present incineration facility at Karlsruhe.

Problems. The furnace was not specifically designed for the combustion of plutonium- or other alpha-contaminated wastes; consequently, it is not sufficiently tight to handle alphe wastes. In theory, only combustible wastes of low plutonium content ( $\leq 10 \mathrm{mg} \mathrm{Pu} / 200-1$ drum) are accspted for incineration. However, occasional room contaminations have occurred. Sometimes the combustible wastes from the reprocessing station have reashed the incinerator with $\sim 100 \mathrm{mg}$ of plutonium (which was not detected by the monitor because of the concentrations of accompanying fission products).

Pressure drop across the silicon-carbide filter candles varies according to how long the candles have been in use. It averages $\sim 996 \mathrm{~Pa}$ (4 in. water gauge) for each filter box. The candle boxes in the present facility last no longer than $\sim 3$ months. Candle cracking is thought to result from thermal stresses caused by the daily shutdown of the furnace for ash removal. Operating personnel also believe that attack by acid gases may contribute to disintegration. Candles are plugged as they crack, until so many candles are plugged that operation is impaired. Then the entire batch of candles is knocked into a waste drum and a new batch inserted.

The exhaust air from the dry cleanup train occasionally had high levels of radioactivity, so a wet scrubber was inserted at the end of the train. The scrubber is used only when the exhaust air approaches prescribed levels of radioactivity.

Retention of Radioactivity. About $99 \%$ of the ash remains in the furnace, while $0.9 \%$ is removed by the first filter and $0.1 \%$ by the second filter. Of the activity initially present in waste fed to the incinerator, $\sim 70-80 \%$ remains with the furnace ash, and $20-30 \%$ is removed by the first and second filters.

c. Proposed Plutonium-Waste Incinerator. At present, only low-level wastes are incinerated at Karlsruhe; plutonium-containing wastes are stored. However, an incinerator for plutonium. contaminated wastes will be needed within the next 
few years. No definite design other than the use of high-temperature combustion filtration has been developed for this incinerator.

d. Combustion of Active Organic Solvents. Combustion of active organic solvents has also been studied at Karlsruhe. An experimental facility for combustion of these solvents has been installed.

\section{SOURCES}

H. Krause, H. Stollberg, and W. Hempelmann, "Treatment of Low-Level Solid Waste at the Karlsruhe Nuclear Research Center," in Proc. Symp. Practices in Treatment of Low- and Intermediate-Level Radioactive Wastes, Vienna, December 6-10, 1965 (IAEA, Vienna, 1966), pp. 699711.

W. Hempelmann and H. Krause, "Treatment of Solid Radioactive Waste at Karlsruhe Nuclear Research Center," Chemie-Ingenieur-Technik, Issue 9 (1970), p. 10.

W. Bahr, W. Hempelmann, H. Krause, and $O$. Nentwich, "Experiences in the Treatment of Low and Intermediate Radioactive Wastes in the Nuclear Research Center, Karlsruhe," in Proc. Symp. Developments in Management of Low- and Intermediate-Level Radioactive Wastes, Aix-enProvence, September 7-11, 1970 (IAEA, Vienna, 1970), pp. 461-483.

W. Bahr, W. Hild, and K. Scheffler, "Experiences in the Management of Plutonium-Containing Solid Wastes at the Nuclear Research Center, Karlsruhe," Proc. Seminar Management of PlutoniumContaminated Solid Wastes, Marcoule Center, France, October 14-16, 1974 (ERDA report CONF741026).

On-site visit by O. R. Li. Rasmusseř, Engineer, Waste Handling and Plutonium rinishing Process Engineering Operations Technical Support Department, Atlantic Richfield Hanford Co., Richland, WA.

H. Krause, Nuclear Research Center, Karlsruhe, personal communication.

S. J. Rimshaw (ORNL) referring to a letter to J. P. Nichols, Chemical Technology Division of ORNL for NUKEM, July 1, 1974.

\section{Other Republic of Germany Facilities}

a. Julich, Berlin, and Two German Industrial Companies. In 1970 incinarators were operating at Julich and Berlin and at two industrial companies. The lack of extensive use of incineration in Germany has been attributed to the fact that incineration has been more expensive than storage unless high throughputs were possible.

\section{SOURCE}

H. Krause, K. Aurand, J. Schwibach, and R. Walter, "Management of Low- and IntermediateLevel Radioactive Liquid and Solid Wastes in the Federal Repubiic of Germany," in Proc. Symp. Developments in Management of Low- and Intermediate-Level Radioactive Wastes, Aix-enProvence, September 7-11, 1970 (IAEA, Vienna, 1970), pp. 101-110.

b. Medical-Biological Facility. An incinerator to reduce the volume of radioactive wastes from animal experiments has also been rerated in Germany. It was designed to handle $\sim 10 \mathrm{~kg} / \mathrm{h}$ of wastes having an activity of $0.1-100 \mathrm{mCi} / \mathrm{kg}$ animbl weight (depending on the toxicity and radiation properties of the radionuclides). A diagram of this facility is given in Fig. 15. Futher information can be found in the source mater.al.

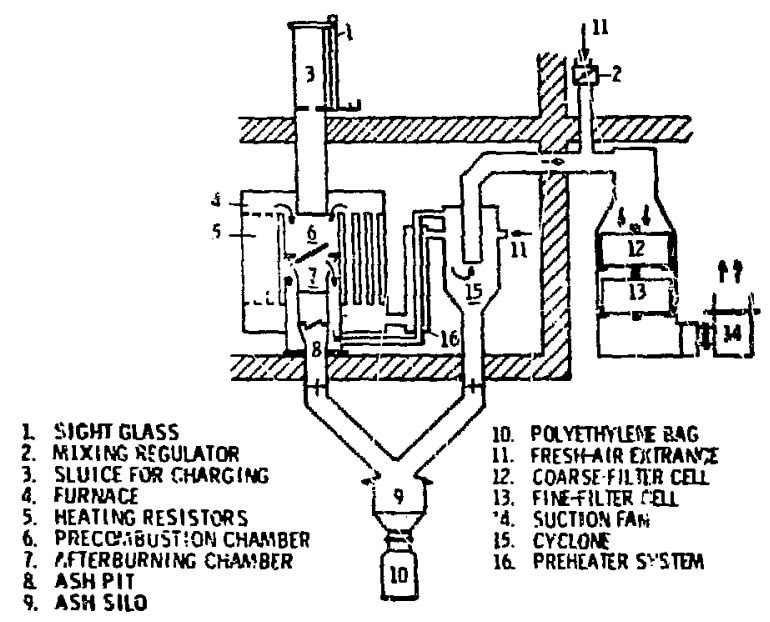

Fig. 15.

Incinerator for Wrist German meancal. biological faciliiy. 


\section{SOURCES}

J. Meissner, "Design and Capacity of a Combustion Plant for Radioactive Wastes from Animal Experiments," in Proc. Symp. Practices in Treatment of Low- and Intermediate-Level Radioactive Wastes, Vienna, December 6-10, 1965 (IAEA, Vienna, 1966), pp. 117-125.

J. Pradel, P. J. Parsons, and E. Malasek, "The Volume Reduction of Low-Activity Solid Wastes," IAEA Technical Report 106 (1970), p. 24.

\section{F. India}

1. Bhahha Atomic Research Center, Trombay. The Bhahha Atomic Research Center has been in operation for $>15 \mathrm{yr}$. Solid radioactive wastes are generated in fuel processing, fabrication, reprocessing. reactor operations, and laboratory research projects.

a. First Incinerator. The first incinerator at the Research Center was constructed in 1963 to incinerate thorium-contaminated wood waste and to serve as a pilot plant for anticipated larger scale. low-level radioactive-waste incineration. This first incinerator was built of inexpensive materials so that their performance characteristics could be studied during burning of alpha-active wastes containing corrosive chemicals. The designed capacity of the furnace was $11.3 \mathrm{~kg} / \mathrm{h}(25 \mathrm{lb} / \mathrm{h})$.

Loading The charging chute, designed with a sliding-plate, double-doored entry, was made of 310 stainless steel.

Incinerator Design. The incinerator was a single chember lined with $15.24-\mathrm{cm}$ (6-in.)-thick, highdensity, alumina refractory cast as a single piece to avoid leakage and having a mild steel casing. The fixed grate in the furnace was 310 stainless steel.

Both overfire and underfire air could be used in the furnace. Kerosene burners were installed to achieve operational temperatures of $500-1000^{\circ} \mathrm{C}$.

Off-Gas Cleanup. To avoid the generation of active liquid wastes, a completely dry gas-cooling and cleaning system was used. The maximum exit-gas temperature from the furnace was $1000^{\circ} \mathrm{C}$. Cooling to $200^{\circ} \mathrm{C}$ was achieved by heat transfer to bare ducts constructed of mild steel. If further cooling was desired, dilution air was added.

After cooling, the gases passed into a single filter bag made of a cleanable fabric filter. Two units were inserted in parallel so that the cleaning operation could be continuous. Access ports permitted bag replacement without spreading contamination. The dust falling from the bag was collected in a drum attached to the unit.

After leaving the filter bag, the gases were further cleaned in a high-efficiency filter made of asbestos glass. The gases then passed through the inciuceddraft fan before exiting to the ambient air through a stack. The alpha contamination in the discharge was $<2 \times 10^{-12} \mu \mathrm{Ci} / \mathrm{m} /$. A layout of the incinerator system design is shown in Fig. 16.

Ash Removal. The ash fell through the grate into an ash hopper with a dump plate, and water sprays were provided inside the hopper. The ash was finally discharged into drums after the furnace had cooled for $\sim 16 \mathrm{~h}$.

Performance. The pilot-plant study showed that incinerator throughput could be increased by a factor of 2 without an increase in the temperature or dust loading. Opinion is that this was possible because some of the volatilized gases may have been burning in the off-gas ducts outside the main chamber. During the last $2 \mathrm{yr}$ of operation, no slagging, spalling, or significant abrasion of the refractory was observed. In addition, there was no noticeable corrosion of the grate. The mild-steel ducts were slightly corroded inside. The dust coating on the ducts may have acted as a protective coating against more serious corrosion. The cooler areas of the system corroded faster than other areas, probably because of condensation of acid vapors. The impeller of the induced-draft fan had to be replaced after $2 \mathrm{yr}$.

Fabric life was $\sim 210 \mathrm{~h}$. No fires were reported in these filters, probably because the length of the duct

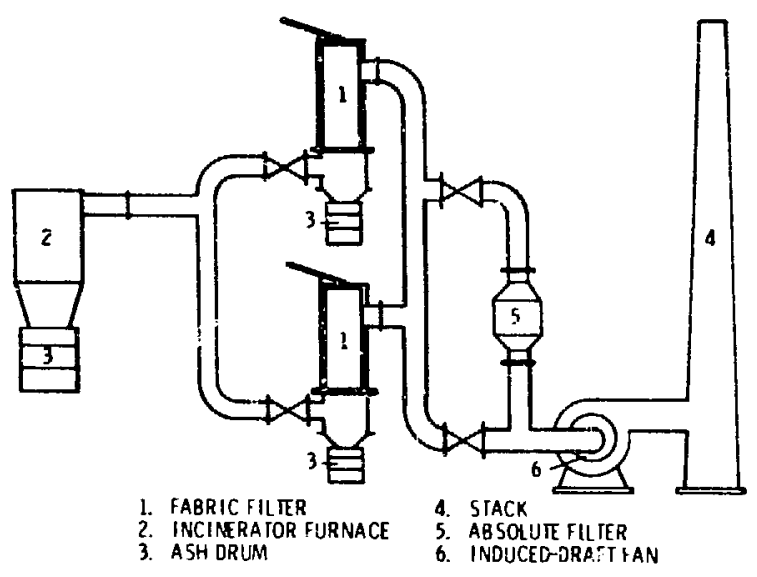

Fig. 16.

First incinerator at Trombay. 
between the furnace and the filter allowed for oxidation and/or complete cooling of the carbon particles.

b. Second Incinerator. By 1966, the experience gained from the pilot system had been used to construct a $45-\mathrm{kg} / \mathrm{h}(100-\mathrm{lb} / \mathrm{h})$ incinerator for low-level (surface $<200 \mathrm{mR} / \mathrm{h}$ ) beta-gamma wastes. By 1970 , $\sim 4000 \mathrm{~kg}$ of combustible wastes were being incinerated each month.

Because this system was intended for long 'icerm operation, material and workmanship were of higher quality than those used in the pilot system.

Incinerator Design. The main steel-cased furnace (Fig. 17) was constructed as two separate chambers separated by two bridge walls with a down-pass between them. The interior lining was made of $45.72-\mathrm{cm}$ (18-in.)-thick refractory brick. Other design features inciude a double-doored charging mechanism consisting of three compartments. A refractory-lined ram in the third compartment pushes the charge into the furnace. The ash-removal arrangement is similar to that of the pilot incinerator.

Combustion air is supplied through a blower and distributed as underfire, overfire, and secondary air, with a control over the quantity of each supply. Combustion air is also supplied through the burners. Two low-pressure oil burners, one in the primary chamber and one in the down-pass, supply the heat that maintains the necessary temperature in the furnace.

Monitoring instruments for this incinerator include a flame detector, thermocouples, pressure indicator, and oxygen analyzer.
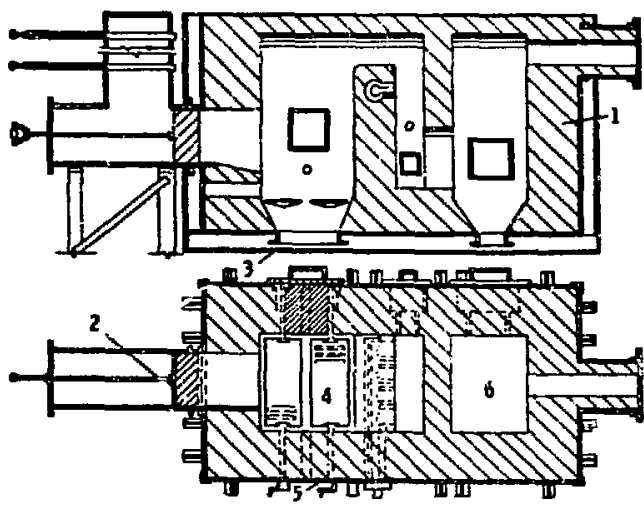

1. FIRE BRICKS

2. CHARGING ARRANGEMENT

3. SECTIONAL EIRVAIION

4. PRIMARY COMBUSTION CHAMBER
5. SECIIONAL PLAN

6. SECONDARY COMBUSTION CHAMBER

Fig. 17.

Second incinerator at Trombay.
Off-Gas Cleanup. The dry gas cleanup system is the same as in the pilot plant, except that a cyclone was added to the train ahead of the fabric filter. The cyclone provides for removal of coarse particulates and for some of the necessary covling of the flue gas.

Performance. The second incinerator is a considerable improvement over the first facility. The double chamber and more complete instrumentation permit more efficient combustion which, in turn, increases the lifetime of the filtration system and reduces the amount of ash.

The new fabric filter permits less pressure drop yet maintains the saine decontamination factor. In addition, the bags need to be shaken less frequently, thereby increasing the filter-bag lifetime.

\section{SOURCES}

A. R. Chinoy, J. D. Sehgal, K. T. Thomas, and R. V. Amalraj, "Management of Radicactive Wastes at 'Trombay," in Proc. Intern. Conf. Peaceful Uses of At. Energy, 3rd, Geneva, 1964 (United Nations, New York, 1965), Vol. 14, pp. 260-268.

K. T. Thomas, A. A. Khan, and R. V. Amalraj, "Incineration of Low-Level Radioactive Solid Wastes and Gas Cleaning: Some Operational Experiences," in Proc. Symp. Practices in Treatment of Low- and Intermediate-Level Radioactive Wastes, Vienna, December 6-10, 1965 (IAEA, Vienna, 1966), „2p. 60i614.

K. T. Thomas, K. Balu, and A. A. Khan, "Waste Management at Trombay: Operational Experience," in Proc. Symp. Developments in Management of Low- and Intermediate-Level Pradioactive Wastes, Aix-en-Provence, September 7-11, 1970 (IAEA, Vienna, 1970), pp. 581-599.

A. A. Khan, R. V. Amalraj, and K. T. Thonas, "Fabric Filtration of Flue Gases from an Active Incinerator: Studies on Design Optimization and Operational Analysis," in Treatment of Airborne Radioactive Wastes, IAEA Proceedings Series, 1968 (STI/PUB/195).

\section{G. Japan}

1. Japanese Atomic Energy Research Institute (JAERI), Tokai. The Tokai waste-treatment plant of the JAERI handles liquid and solid radioactive wastes produced by the Institute's research facilities and reactors and by other atomic energy facilities, as 
well as the wastes collected by the Japan Radioisotope Association (JRIA) from various locations lintoughout Japan. Low-level, nontransuranic, solid wastes ( $<50 \mathrm{mR} / \mathrm{h}$ on the surface) are sorted at the generation site into combustible and noncombustible wastes. Combustibles are placed in 20- 1 boxes, 200- 1 drums, or a polyvinyl sheet, transported to the treatment area, and placed in temporary storage. The wastes are composed chiefly of paper, cotton cloth, and wood. Plastics and rubber are not classified as combustibles in Japan (but they are occasionally incinerated).

\section{a. 50-kg Incinerator}

Incinerator Design. An incinerator with a 50 . $\mathrm{kg} / \mathrm{h}$ throughput capacity was placed in operation in 1966 (Fig. 18). The $\sim 1000^{\circ} \mathrm{C}$ operating temperature is maintained by two oil burners, one in the primary combustion chamber and one in the secondary com. bustion chamber.

Off-Gas Cleanup. The otf-gas cleanup train consists of a spray-scrubber for washing and cooling the gases, a cyclone for coarse-particulate removal, an electrostatic precipitator for further mist and particulate removal, a cooler-heater unit to reduce clogging in the filters, a cloth filter unit, an absolute filter (HEPA) unit, and an induced-draft fan.

The liquid residue from the cleanup vessels is cool. $e d$, filtered, and recycled to the spray-scrubber. Sodium hydroxide is added to maintain a basic solution. Blowdown from the system is treated by an evaporation process.

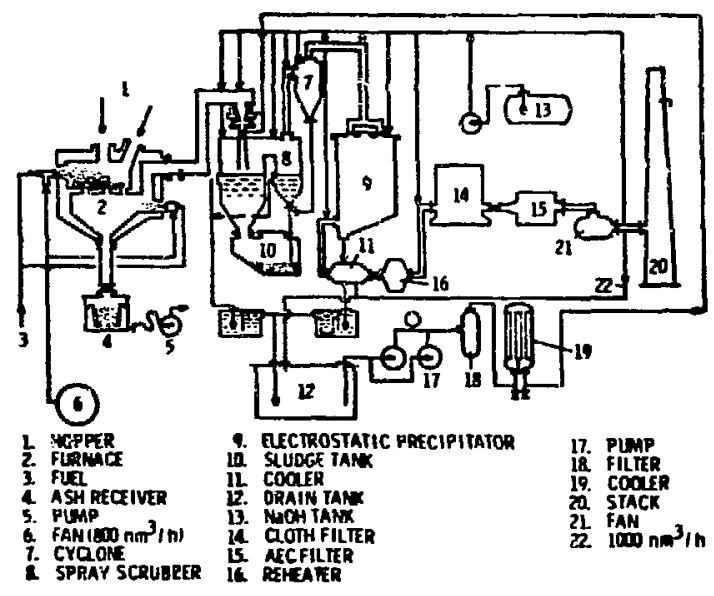

Fig. 18.

Incinerator $(50 \mathrm{mg} / \mathrm{h})$ at Tokai.
Ash Removal. Ashes from the incineration chambers fall into a cloth bag located in a water tank. When the bag is full, the ash-collection unit is closed off, the water pumped from the tank, and the ash bag removed. The ash is solidified in a steel drum by the addition of cement.

Performance. Operation records of the incinerator in 1970 are shown in Fig. 19, and Fig. 20 shows the material balance for the incinerator. indicating that $170 \mathrm{mn}^{3}$ of material went into the incinerator, whereas $94.2 \mathrm{~m}^{2}$ of residue came out.

The distribution of radioactivity in the facility has been studied, and for the radionuclide $32 \mathrm{P}, 93 \%$ of the activity remained in the ash, $5 \%$ was found in the spray-scrub solution, $0.5 \%$ in the electrostatic precipitator, $0.02 \%$ in the cloth filter, and $0.3 \%$ in the duct of exhaust gas.

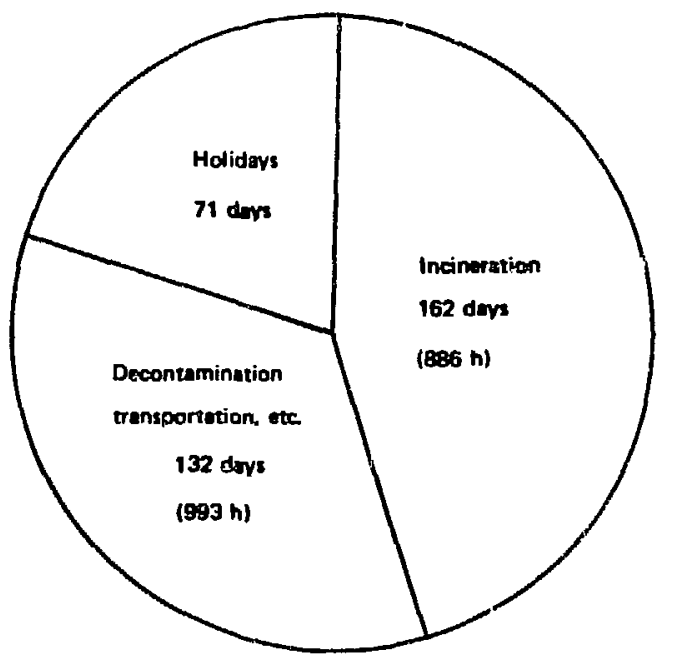

\begin{tabular}{|c|c|c|c|}
\hline \multicolumn{2}{|c|}{$\begin{array}{c}\text { Decontamination } \\
\text { Inumber of timest }\end{array}$} & $\begin{array}{l}\text { Exchange of filters } \\
\text { (number of st.eets) }\end{array}$ \\
\hline Ducts & 30 & $\begin{array}{l}\text { AEC } \\
\text { filter }\end{array}$ & 20 \\
\hline Cortrell & 45 & $\begin{array}{l}\text { Coth } \\
\text { filter }\end{array}$ \\
\hline Other & 65 & \\
\hline
\end{tabular}

Fig. 19.

Operation records for 1970 of the $50-\mathrm{mg} / \mathrm{h}$ incinerator at Tokai. (Taken from IAEA Regional Training Course on Radioacíive Waste Management, Japan, November 4-24, 1971.) 


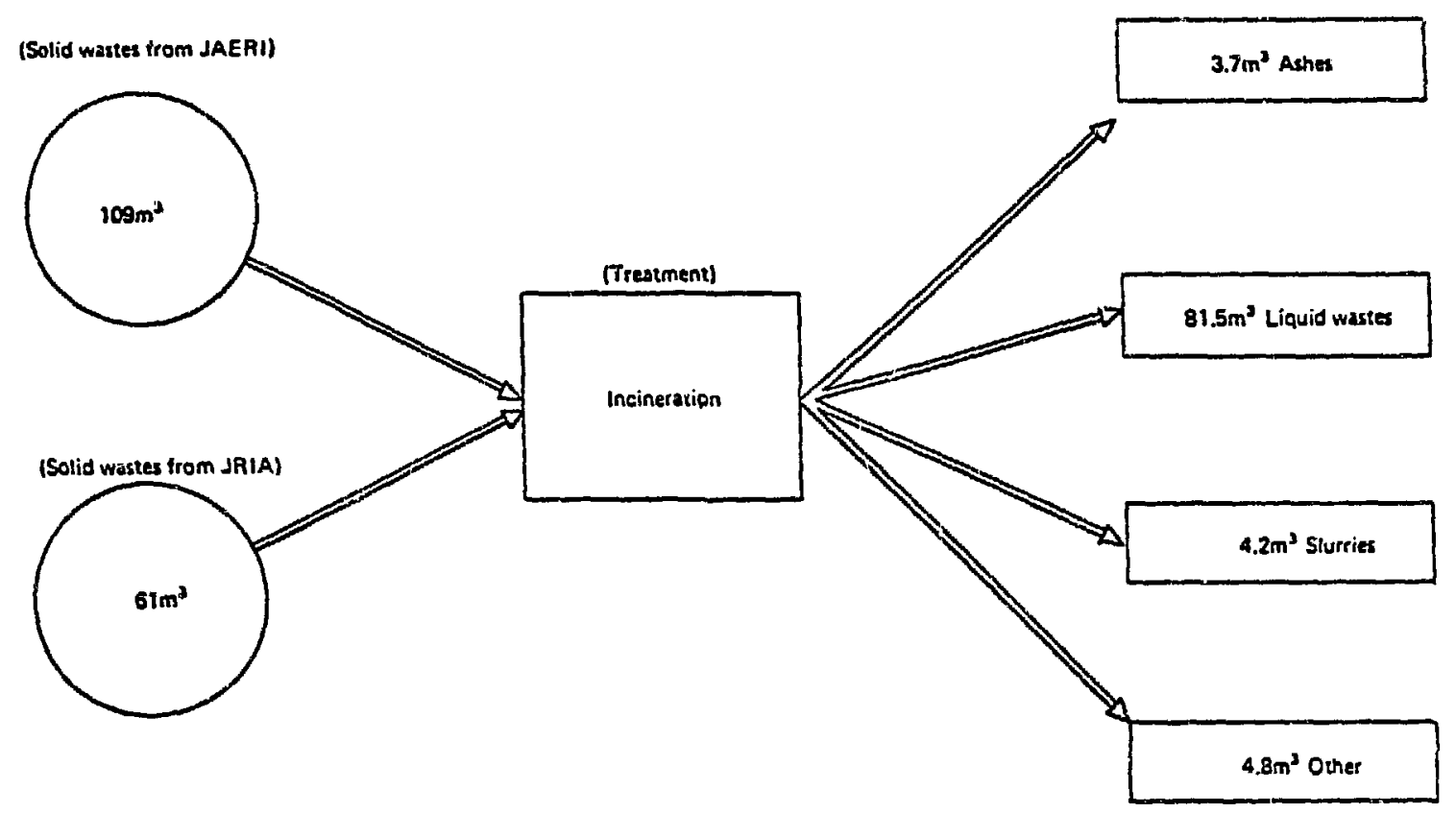

Fig. 20.

Material balance for $50-\mathrm{mg} / \mathrm{h}$ incinerator at Tokai. (Taken from IAEA Regional Training Course an Radioactive Waste Management, Japan, November 2-24, 1971.)

Problems. To achieve higher temperatures and thus improve combustion, the cast iron of the furnace was replaced with firebricks. Aluminum-foil electrodes in the electrostatic precipitator were replaced with stainless steel. Also, corrosion has necessitated replacement of many parts of the offgas cleanup system. Cleaning of the system and replacement of the cloth filters is required at regular intervals.

b. Cther Tokai Incinerators. An incineration facility with a $30-\mathrm{kg} / \mathrm{h}$ capacity and similar in design to the $50-\mathrm{kg} / \mathrm{h}$ facility is also operated at Tokai.

In 1973 , a small incinerator with a $12-\mathrm{kg} / \mathrm{h}$ capacity was built to test the use of high-temperature ceramic filters in the off-gas cleanup train.

The train consists of a two-filter chamber with 36 alumina filter elements (mean pore size, $40 \mu$ ) in each unit. The first unit operates at $\sim 800^{\circ} \mathrm{C}$. Particulates and tars from the incinerator lodge on the filter elements and oxidize. After passing through the first high-temperature unit, the gas is free of sist and contains little $\mathrm{CO}$ or tar. The total decontamination factor of the facility, measured with respect to the content of ${ }^{132} \mathrm{Cs},{ }^{85} \mathrm{Sr},{ }^{59} \mathrm{Co}$, and ${ }^{32} \mathrm{P}$, is $\sim 1.6-7.6 \times 10^{5}$.

\section{SOURCES}

Y. Nagai, Radioactive Waste Management Practices in Japan (Nuclear Energy Agency Organization for Economic Cooperation and Development, Paris, 1974).

C. Machida, "Radioactive Waste Management in Tokai Research Establishment, JAERl," IAEA Regional Training Course on Radioactive Waste Management, Japan, November 4-24, 1971.

K. Kato, K. N'aito, and C. Machida, "Decontamisation of Radioactivity from Waste Incinerator Exhaust-Gas at Tokai Establishment, JAERI," Hoken Butsuri 9, $81-86$ (1974).

C. Machida and K. Kato, "Performance Examination of the Radioactive Waste Incinerator," Waste Manage. Res. Abstr., No. 8 (1973), p. 81.

Y. Wadachi, "Treatment of Radioactive Solid Wastes with Incineration and Compression," IAEA Regional Training Course on Radioactive Waste Management, Japan, November 4-24, 1971. 
C. Machida et al., "Development Studies of the Incinerator Using Ceramic Filte: Elements," Waste Manage. Res. Abstr. No. 9 (1974), pp. 22-23.

\section{Oarai Research Establishment of the JAERI}

Low-Level Radivactive-Waste Incinerator. An incinerator for materials contaminated with small quantities of low-level ( $<50 \mathrm{mR} / \mathrm{h}$ surface) betagamma-emitting radionuclides has been in operation at the Oarai facility since 1973.

Pretreatment and Loading of Wastes. When the wastes are received at the facility, they are sorted in glove boxes. The wastes include paper, cloth, and wood; plastics and rubber are usually excluded unless the amount of plastic does not exceed $30 \%$ of the total weight of the waste. The sorting-loading furnace section is shown in Fig. 21. The sorted waste is repacked in cartons and placed in the loading chute. When conditions are suitable, the incinerator door is opened and the waste is charged into the primary combustion chamber, one carton at a time. It is possible to charge about $30 \mathrm{~kg} / \mathrm{h}$.

Incinerator Design. The incinerator contains primary, secondary, tertiary, and final combustion

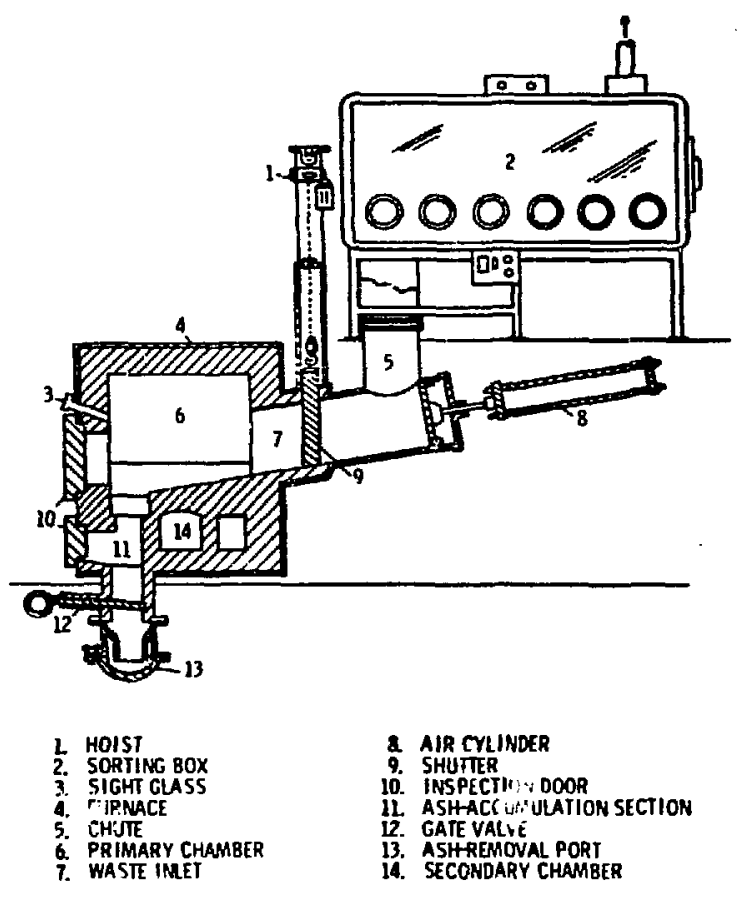

Fig. 21.

Sorting-loading furnace section of low-level incinerator at Oarai. chambers. Two types of high-alumina firebricks, two types of clayey firebricks, and castable refractories were used in the construction of the incinerator. During operation, the temperature in the primary chamber runs between $600-900^{\circ} \mathrm{C}$, with each successive chamber being slightly cooler. The design temperature at the exit is $<500^{\circ} \mathrm{C}$; should the temperature be $>500^{\circ} \mathrm{C}$, cooling air is introduced into the final combustion chamber. Oxidation and decomposition occur in the primary chamber, further oxidation occurs in the secondary chamber, and the last two chambers provide further oxidation and settling of particulates. This arrangement results in a low dust-loading at the furnace exit $\left(<0.1 \mathrm{~g} / \mathrm{nm}^{3}\right)$.

Proper operating temperatures are maintained by a kerosene burner in the primary chamber and a propane burner in the secondary chamber. The furnace is operated at a vacuum of -49 to $-98 \mathrm{~Pa}(-5$ to $-10 \mathrm{~mm}$ water gauge).

Off-Gas Cleanup. The off-gas cleanup system is shown in Fig. 22. As the gases leave the incinerator, they are cooled in two heat exchangers arranged in series, pass through an electrostatic precipitator for removal of particulates, are further cooled in another heat exchanger, and pass through a dry filter for further particulate removal. Finally, they pass through a wet scrubber, where any acid gases are absorbed by a $\mathrm{NaOH}$ solution.

Ash Removal. Ash on the floor of the primary chamber is pushed by the successive charged cartons and falls into the ash-accumulation section. About once a week the system is shut down and allowed to cool. The ash is then put into plastic bags through the removal port shown in Fig. 21, and solidified with cement.

Performance. From February 1973 to February $1975,82.8 \mathrm{~m}^{3}(7892 \mathrm{~kg})$ of waste were incinerated. Ash volume was 720 /, weighing $238.4 \mathrm{~kg}$. Concentration of radioactivity in the flue gas runs $<10^{-13}$ $\mu \mathrm{Ci} / \mathrm{cm}^{3}$.

Problems. The emergency $\mathrm{CO}_{2}$ system, which was to serve as a fire precaution, is rendered useless by the $\mathrm{CO}_{2}$ being rapidly expelled along with the flue gases. Corrosion has occurred in various parts of the incinerator, including the dust collecting and discharge plates of the electrostatic precipitator. Insulators in the electrostatic precipitator have broken down, resulting in insufficient voltage and current for proper operation of the collector. 


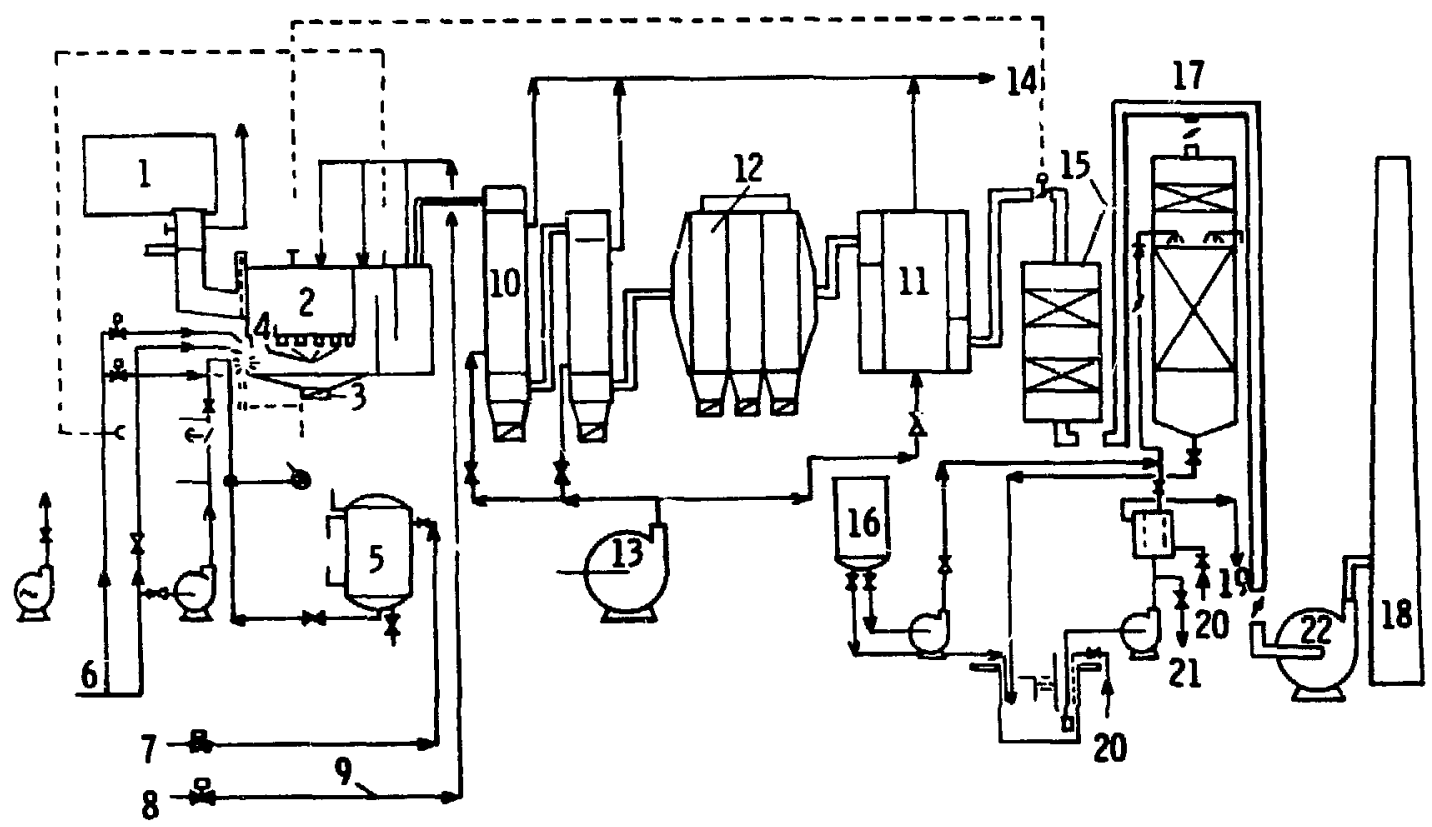

12. ELECTROSTATIC PRECIPITATOR

13. CDOLING-AIR BLONER

14. TO ATMOSPHERE

15. FILTER UNIT

16. NaOH TANK

17. SCRUBBER

18. STACK

19. DRAIN

20. WATER SUPPLY

21. HOT DRAIN

22. MAIN BLOWER

Fig. 22.

Off-gas cleanup system of the low-level incinerator at Oarai.

\section{SOURCES}

S. Sakata, Chief, Waste Management and Decontamination Section, JAERI, Oarai Research Establishment, written communication, 1975.

S. Sakata, Y. Shinji, and M. Abe, "Pyrolysis Type Incinerator." Waste Manage. Res. Abstr. No. 9 (1974).

\section{H. Canada}

\section{Inactive Facilities}

a. Chalk River Nuclear Laboratories (CRNL), Ontario. In the early 1960's, CRNL built a pilot incinerator to investigate the problems, volume reduction, and cost of incinerating radioactive wastes. 
Pretreatment of Wastes. At that time, the wastes consisted mostly of paper, with some plastic film, rubber gloves, mops, rags. floor sweepings, and small noncombustible items. These wastes arrived at the incinerator site in sealed bags, and no sorting was undertaken other than exclusion of propane cylinders. If $t^{2}$ te bagged waste had a surface gamma dose rate of $<200 \mathrm{mR} / \mathrm{h}$, it was charged to the in cinerator. The average level was $5 \mathrm{mR} / \mathrm{h}$.

Loading. Wastes were loaded through a doubledoored, ram-feeder arrangement (Fig. 23). Door A opened, and the bag was placed into the load area; door A closed; door C opened, and door B opened under the bag, which dropped into the feed chamber in front of door $\mathrm{C}$. Door $\mathrm{C}$ then closed, pushing the bag into the main combustion chamber. Interlocks prevented the doors from operating in the wrong sequence.

Incinerator and Delay-Chamber Design. The incinerator consisted of a primary combustion chamber, a mixing chamber, and a secondary combustion chamber lined with $15.24-\mathrm{cm}(6-i n)$-thick castable refractory. The steel shell had a $5.08 \cdot \mathrm{cm}(2$ in.)-thick block insulation to separate the refractory from the steel. Incinerator dimensions were 365.76 cm by $121.92 \mathrm{~cm}$ by $213.36 \mathrm{~cm}$.

Combustion air was supplied to the primary chamber as both underfire and overfire air. The overfire air first flowed through and cooled the feed chamber. Secondary air entered the mixing chamber between the primary and secondary chambers.

A propane burner maintained a temperature of at least $815^{\circ} \mathrm{C}$ in the primary chamber, while another

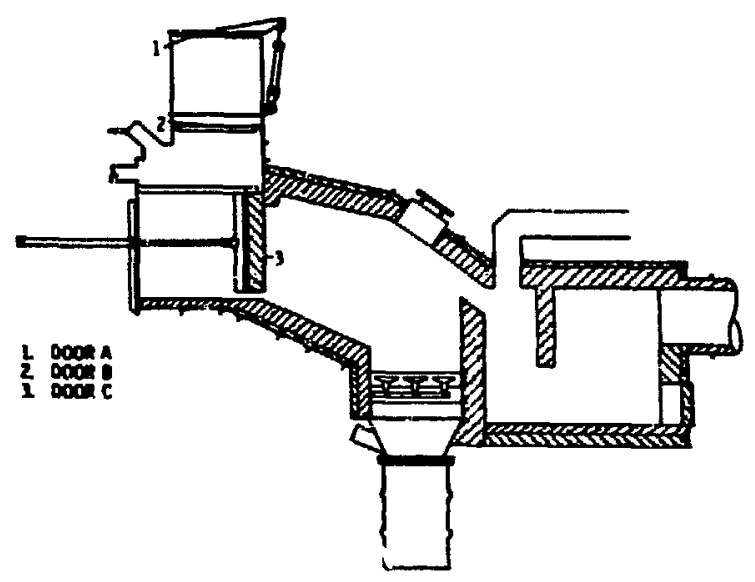

Fig. 23.

Ram-feeder arraigement of Chalk River incinerator. burner was used as an afterburner in the mixing chamber.

In the final configuration, a large steel chamber (delay tank), $137.16 \mathrm{~cm}(4.5 \mathrm{ft})$ in diameter and $548.64 \mathrm{~cm}(18 \mathrm{ft})$ high, was installed in the duct connecting the incinerator to the filter system. In the $\sim 4$ $s$ it took for the gases to traverse this chamber, most of the glowing sparks burned out before reaching the baghouse.

Cooling and Off-Gas Cleanup. Ambient air was bled into the inlet duct of the baghouse to cool the gases to $232-260^{\circ} \mathrm{C}$. The baghouse was made of glasscloth bags in two separate sections to permit the bags in one enclosure to be cleaned by reverse flow while the off-gases (partially damped) flowed through the other enclosure. From the baghouse the gases flowed through an absolute filter assembly and induced-draft fan before entering the stack. A damper upstream of the fan was used to maintain the pressure in the incinerator at $-249 \mathrm{~Pa}(-1$ in. water gauge). The gases were exhausted to the atmosphere through a refractory-lined stack. A bypass arrangement was provided so that in an emergency the gases could vent from the incinerator directly to the stack.

Ash Removal. Burning waste moved down the sloping hearth to grates at the back of the primary combustion chamber. Ashes and small pieces of noncombustibles were shaken through the grates into a drum located at the bottom of the ash chute. When the incinerator was cooled, the ash in the drum was sprayed with water and the cirum removed and capped. Material that would not pass through the grates was removed through a hatch in the incinerator roof. A drum at the bottom of each baghouse collected the fly ash that flaked off the bags.

Performance. The incinerator was operated at throughputs of $\sim 250 \mathrm{~kg} / \mathrm{h}(500-600 \mathrm{lb} / \mathrm{h})$. During operation, combustion temperatures of $\sim 760-1204^{\circ} \mathrm{C}$ were observed. Because smoke emission was reduced at the upper combustion temperatures, intermittent use of the propane burner in the primary chamber and continuous use of the burner in the mixing chamber were frequently required.

Problems. During the equivalent of $1 \mathrm{yr}$ of active burning, serious cracks appeared in the curtain wall. Brick columns were installed to prevent the wall from falling. The tilting grate did not permit discharge of large, noncombustible objects. Inadvertent introduction of propane cylinders into the bags of waste caused small explosions almost daily. 
However, no explosion caused serious contamination.

After the installation of a delay tank, before the bag filter, the bags in the baghouse suffered no loss of strength. Therefore, after this modification was made there was probably no oxidation of fly ash on the fabric. The baghouse removed $\sim 96 \%$ of the radioactivity.

The absolute filters did not perform as well as expected, but because the baghouse filters were efficient, no extensive study was made of the poor performance of the absolute filters.

The floor beside the feed chamber became active from broken or leaking bags and it was necessary to mop this area as soon as each shipment of waste had been burned. Contamination also occurred occasionally in the area below the incinerator ash chute.

This incinerator ran for about 1 yr. The operation was uneconomical at that time, and as there was no requirement to recover any particular radionuclide, rhe facility was shut down. Redesign recommendations included designing the grates to open wide enough for the discharge of large objects, increasing the slope of the hearth, and equipping the baginouse with shakers.

\section{SOURCES}

D. H. Charlesworth, CRNL, written communication, 1975.

D. W. McQuade, "CRNL Aitive Waste Incinerator," At. En. Canada report AECL-2248 (February 1965).

J. Joyce, CRNL, written communication, 1975.

b. Douglas Point Generating Station. Ontario. Very low-level wastes produced at the Douglas Point Generating Station have been incinerated there. Combustible wastes with a contamination level of $\leq 25 \mathrm{mR} / \mathrm{h}$ (measuied at $30.5 \mathrm{~cm}$ from the container bag) were dumped in open pits, where they were ig. nited and allowed to burn.

\section{SOURCE}

G. A. Mawson, "Radioactive Waste Management at Canadian Nuclear Power Reactors," in Management of Radioactive Wastes at Nuclear Power Plants,
IAEA Safety Series No. 28 (ST.PUB/208) (IAEA, Vienna, 1968), pp. 59-76.

\section{Facilities under Construction}

a. Bruce Nuclear Complex, Ontario. The Bruce incinerator is being built by Ontario Hydro as part of a radioactive-waste storage site. It will be used to incinerate all of the low-level combustible waste produced at the Pickering, Douglas Point, and Bruce Nuclear generating stations.

The incinerator will be a controlled-air, batch. loaded type. Primary partial combustion and volatilization will occur in a primary chamber. The gases will then pass to 2 gas-heated, hightemperature afterburner for further oxidation. The off-gas will be cooled indirectly to $204^{\circ} \mathrm{C}$ before passing through a baghouse to the stack. This incinerator is scheduled for operation in 1976.

b. Chalk River Nuclear Laboratories (CRNL), Ontario. The incinerator to be installed at Chalk River will be similar to, but smaller than, the one at Bruce $\because$ clear. It is intended primarily for incinerator development work, although ic will be used to incinerate most of the low-level combustible wastes generated at CRNL. The CRNL unit will be used to test new types of filters and will burn more active wastes, so the stack gas will also be passed through a HEPA filter before discharge.

\section{SOURCE}

D. H. Charlesworth, CRNL, written communication, 1975.

\section{LS INCINERATION FACILITIES}

\section{A. Early US Incinerators}

\section{Mound Latoratory, Miamisburg, ОН}

a. Early Pilot Plant. In 1948 a pilot-plant incinerator and off-gas cleanup system were built at Mound Laboratory. The facility consisted of an incinerator, a steam ejector, a water-cooled expansion chamber, and a combination spray and packed tower.

The purpose of the facility was to test an incineration system for radioactive wastes. The steam ejector was used to study the ability of the system to remove 
fine particulates. It was hoped that the steam ejector would not only maintain the required negative pressure in the system but would also aid in off-gas cleanup by serving as a unit in which water would condense out on the particulates contained in the off-gases.

A limited number of tests indicated that $\sim 98.8 \%$ of the radioactivity in the off-gases was collected in the cleanup train. Further details of the facility are available from the listed sources.

b. Follow-Up Pilot Plant. The initial pilot-plant results and nozzle studies were considered encouraging. Therefore, another facility, which included an incinerator with a throughput canacity of $\sim 6.81 \mathrm{~kg} / \mathrm{h}(15 \mathrm{lb} / \mathrm{h})$, was constructed in 1950 to study the entire process further.

Loading. An air-lock arrangement with sliding gates permitted the furnace to be charged (without gas leakage to the surrounding atmosphere) while combustion was taking place. An airtight box surrounded the gates.

Incinerator Design. The cylindrical incinerator (Fig. 24) was $26.67 \mathrm{~cm}$ (10.5 in.) in diameter and $60.96 \mathrm{~cm}$ (24 in.) high. The burning charge rested on a $2.54-\mathrm{cm}$-thick, perforated, cast-iron grate which could be rotated to dump noncombustibles and ashes. The burning area was surrounded by a stainless-steel liner, $0.32 \mathrm{~cm}$ thick, set inside a section of steel pipe. Two electric heating elements were placed between the liner and the shell. Tangentially directed air and/or oxygen entered through four ports just above the burning area.

Off-Gas Cleanup. The gases from the fumace exited through a pipe at the top of the ash hopper. A coarse-filter box, located below the exit pipe, filtered out large pieces of fly ash (Fig. 24).

In the cleanup train (Fig. 25), the gases passed through (1) a rough washer consisting of a countercurrent water spray; (2) a heat exchanger which cooled them to room temperature; (3) a PeaseAnthony scrubber where particles with a diameter larger than $\sim 2 \mu$ were removed; and (4) another heat exchanger into (5) a nozzle system. A Nash pump was placed in the train after the scrubber to provide the pressure drop necessary to move the gas. es from the incinerator to the steam nozzle.

In the nozzle system steam and off-gases were mixed, the effluent was exhausted inio (6) a watercooled expansion chamber, (7) a heat exchanger and (8) a Pease-Anthony scrubber. Finally, the gases passed through (9) a blower and (10) a CWS filter

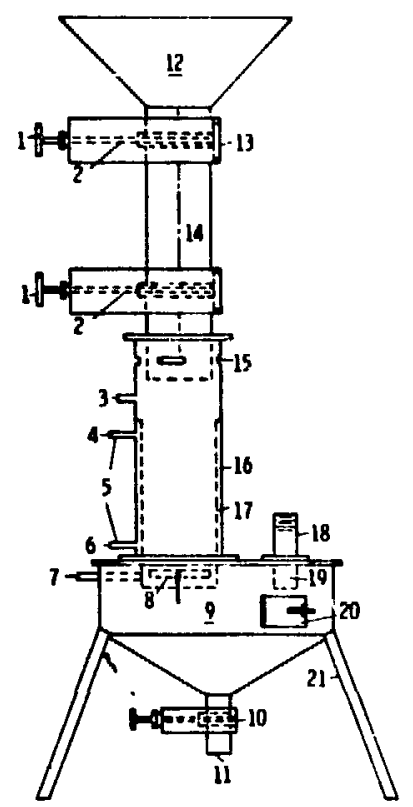

1. OPERATING HANDLE
2. SLIDING GAIES
3. PRESSURE GAUGE AND CO
EXTINGUISHING CONNECIION
4. INET
5. NICHROME WINDINGS
6. OUTLET
7. THERMOCOUPLE CONRECTION
8. CAST-IRON GRATE
9. ASH HOPPER
10. SLIDING GAIE
11. ASH EXIT

12. LOADING HOPPER

13. AIRTIGHT COVER

14. AIRLOCK 110 -in. PIPEI

14. AlRLOCK I10-in. PIPE

TANGENTIAL OXYGEN - AIR
(FOUR - $90^{\circ}$ INTERVALSI

16. BURNING AREA OUTER SHELL

(iz-in. PIPE)

17. STAIMLSSS-SIEEL LINER

18. Fi UE-GAS EXIT (3-in. PIPE)

19 COARSE-FILTER BOX

20. ASH HOPPER ACCESS DOOR

21. ANGLE-IRON LEGS

Fig. 24.

Pilot incinerator at Mound Laboratory.

before exhausting into the building's ventilation system.

Tests using $0.3-\mu$ DOP smoke indicated that the steam-nozzle system was needed in the cleanup train to remove very small particles. Twc types of nozzle were used in these tests.

Ash Removal. The ash hopper (Fig. 24) had sloping steel walls which tapered to an opening provided with a sliding gate for ash removal.

Performance. During the first five incinerator runs made with uncontaminated combustible wastes, gas leaks were discovered and corrected. After these five runs, the cast-iron grate disintegrated and was replaced by one of stainless steel. The incinerator was designed for operation under 249-498 $\mathrm{Pa}$ (1-2 in. water gauge) vacuum. However, during operation there were pressure surges of the order of 1 in. of water, with a maximum of about 5 in., for about $30 \mathrm{~s}$ after each new charge. There is no 


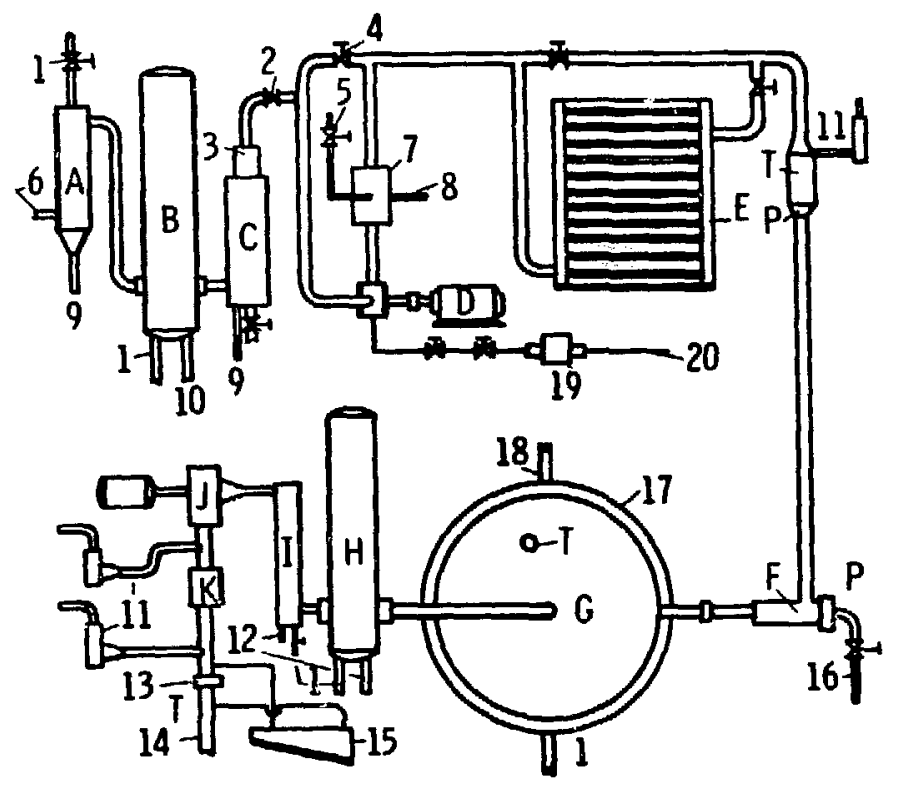

$$
\begin{aligned}
& \text { A - ROUGH WA SHER } \\
& \text { B - HEAT EXCHANGER } \\
& \text { (WATER-COOLED) } \\
& \text { C - PEASE - ANTHONY TYPE } \\
& \text { SCRUBBER } \\
& \text { D - GAS PUMP (NASH) } \\
& \text { E - HEAT EXCHANGER } \\
& \text { (WATER-COOLED) } \\
& \text { - STEAM NOZZLE } \\
& \text { G - EXPANS ION CHAMBER } \\
& \text { (WATER-COOLED) } \\
& \text { H - HEAT EXCHANGER } \\
& \text { (WATER-COOLED) } \\
& \text { I - PEASE - ANTHONY TYPE } \\
& \text { SCRUBBER } \\
& \text { I - BLOWER } \\
& \text { K - C. W. S. FILTER } \\
& \text { P - PRESSURE GAUGES } \\
& \text { T - THERMOMETERS }
\end{aligned}
$$

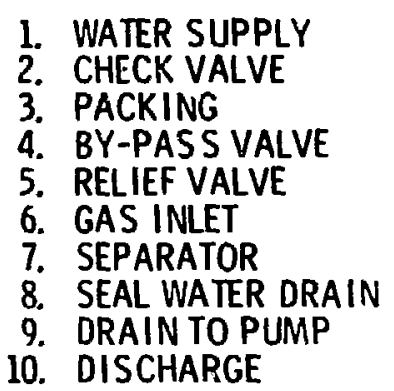
11. GAS SAMPLER
12. DRAIN
13. ORIFICE PLATE
14. GAS DISCHARGE
15. DRAFT CAUGE
16. 120\# STEAM
17. COOLER
18. COOLING-WATER DISCHARGE
19. WATER METER
20. SEAL WATER

Fig. 25.

Cleanup train of follow-up incinerator at Mound Laboratory.

information as to how this excess pressure was vented.

After the five "cold" runs, seven hot runs were made. The off-gas cleanup train was very efficient at removing radioactive material, with overall decontamination factors of $10^{7}-10^{9}$. The average contaminated water output per hour was $\sim 1078$, (285 gal). It has been estimated that $4777 /(1262$ gal) of water (which became contaminated) were required for treatment of gases from $9.08 \mathrm{~kg}(20 \mathrm{lb})$ of solid waste. The activity level in the room housing the pilot-plant equipment became considerably higher than that in the exit flue gases because of a slight leakage at threaded connections and seal glands.

Both oxygen and air were usually used during incineration. In the one case where air alone was used, the fire smoked badly. During incineration, the ash hopper became cherry red and scaled, hence cooling would be needed for continuous operation.

Despite the fact that these pilot-plant studies were undertaken to furnish design criteria for a large $[54.48-\mathrm{kg} / \mathrm{h}(120-\mathrm{lb} / \mathrm{h})]$ incineration facility, and despite the fact that much design work had been donf, the larger facility was never built. As far as can be cletermined, the pilot-plant facility was never used after the initib! testing period.

\section{GOUHCES}

P. J. Schauer, "Pilot Plant Work on Solid Burnable Waste Disposal for Mound Laboratory," Mound Laboratory report MLM-232, (November 1948). 
M. McEwen, P. J. Schauer, and T. Aponyi, "Development of the Flow Sheet for Incinerating Contaminated Combustible Waste," Mound Laboratory report MLM-567 (May 1951), p. 51.

R. Dennis and L. Silverman, "Radioactive Waste Incineration Design and Operational Experience - A Review." in Seventh AEC Air Cleaning Conf., October 10-12, 1961, Held at Brookhaven National Laboratory, Upton, NY," AEC report TID-7627 (March 1962) pp. 418-419.

A. Rossano, Jr., L. Silverman, and M. W. First, “A Preliminary Field Survey of Air Cleaning Activities at Atomic Energy Commission Facilities. September - November 1950," AEC report NYO-1580 (February 1951). p. 41.

2. Knolls Atomic Power Laboratory (KAPL), Schenectady, NY. In 1949 the Chemical Engineering Division at KAPL was authorized to build an incinerator and flue-gas treatment pilot plant to study the incineration and off-gas cleanup of radioactive combustible solid wastes.

a. Incineration (1949-1950). The incinerator was designed for an input of $-9.08 \mathrm{~kg} / \mathrm{h}(20 \mathrm{lb} / \mathrm{h})$. Pure oxygen was introduced into the incinerator so that the volume of off-gases would be minimized. It was hoped that the off-gas treatment system could be designed so that the gases could be "dead-ended."

Off-Gas Cleanup. The first gas-treatment train consisted of (1) a water-jacketed condensation column to cool and partially dehydrate the combustion gases, (2) a sulfur burner to remove all free oxygen, (3) an agglomeration section using steam, (4) a packed absorption tower using a diethanolamine solution to remove $\mathrm{CO}_{2}$ and water from the gas stream, (5) a Pease-Anthony centrifugal washer, (6) a reheater and FG $25-50$ glassfiber medium, and (7) a CWS filter.

Performance. Tests run on this incinerator and cleanup train were not satisfactory. Excessive pressure drops were produced by the many pieces of equipment in the cleanup train. Burning in the furnace was poorly controlled and the static pressure in the furnace ranged from 4980 to $-4980 \mathrm{~Pa}$ (20 to -20 in. water gauge). After about $1 \mathrm{~h}$ of burning, the absorption tower would become fouled and plugged with tar and fly ash.

Because of the unsatisfactory performence, the concept of dead-ending the off-gases was aban- doned. In the fall of 1950 the system was completely redesigned.

\section{b. Incineration (1950-1951)}

Loading. The wastes were charged through a chute equipped with an air lock. The final feed rate was increased to $18.16 \mathrm{~kg} / \mathrm{h}(40 \mathrm{lb} / \mathrm{h})$.

Incinerator Dosign. In the modified system the furnace unit was retained. This unit was lined with a firebrick wall to improve combustion. To preheat the chamber to above $538^{\circ} \mathrm{C}$, an auxiliary propane-gas burner was first used, and later a CWS filter was placed in the chamber and burned. A propanefueled bumer was used at all times to maintain a flam: in the chamber. Under certain feed concitions some air, in addition to oxygen, was used in the in. cinerator.

The facility was instrumented with flow-rate meters, temperature indicators, pressure indicators. etc. Sampling ports were located at various points in the cleanup train.

Off-Gas Cleanup. In the new off-gas treatment train, equipment having a very low pressure drop was installed. The train included (i) a settling chamber with fine water sprays and baffles, (2) a Pease-Anthony scrubber, (3) a condenser and reheater, (4) a filter system consisting of a glass Dustop filter and two CWS filters (in parallel), and (5) an induced-draft fan. A bypass across the scrubber was provided in case of excessive pressures.

Ash Removal. Ash dropned thrcugh a rigid grate in the bottom of the furnace chamber and was remnved through a pipe to a drum receiver. A hydraulic-lift truck supplied pressure on the drum to insure a tight connection between the drum and pipe.

Performance. The modified pilot plant operated for about a year. From March through April 1951. $5448 \mathrm{~kg}(12000 \mathrm{lb})$ of waste were burned. A larger incinerator was needed, but incineration was expen. sive from the standpoint of capital investment and operating costs. Baling had been suggested as an alternative but had not been tried because of the anticipated spread of radioactive contamination through dust. T'ests on a hand-operated paper baler allayed these fears, and a hyriraulic paper baler was purchased and put into operation.

Problems. The modified unit was much more successful than the original unit, but there were 
some problems. Because the grates could not be rotuied. any noncombustibles had to be removed by raking or prodding, with access available only through the charging chute. The charging mechanism warped, and a different charging design was recommended. Because of fluctuations of pressure in the incinerator. it was difficult to maintain a lame in the burner.

The liquid-discharge lines from the settling chamber and scrubber often plugged. A steam nozzle was installed to clean the discharge line of the scrubber. It was recommended that scrubbing units be designed with better cleaning facilities and better drainage.

Analysis of corrosion found in parts of the cleanup train indicated the presence of sulfate. The sulfur apparently originated in the paper that wes burned.

During some periods of operation the activity in the exhaust gases increased. usually because of improperly installed or tor filters. At times, room samplers showed an increase in room activity which could usually be attributed to leakage due to pressur: buildup caused by plugged filter equip. ment.

Oil-soaked or strip-cnated materials gave off an excessive amount of tarry materia!s. Baled charges burned evenly and put the least strain on the system.

\section{SOURCES}

A. Rossano, Ir.. L. Silverman, and M. W. First. "A Preliminary Field Survey of Air Cleaning Activities at Atomic Energy Commission Facilities, September-November 1950." ARC report NYO-1580 (February 19511. pp. 20-41.

F. A. Schell. "A Report on the Development and Operation of a Pilot Incinerator for Contaminated Combustible Solid Wastes," Knolls Atomic Power Laboratory report KAPL.-610 (October 195̃l).

R. E. Larson and R. H. Simon. "Solid Waste Disposal at the Knolls Atomic Power Laboratory." Knolls Atomic Power Laboratory report KAPL-936 (.June 1953). pp. 11-12.

3. Argonne National Laboratory (ANL). Argonne. It. At ANL in the late 1940's, - $80 \mathrm{vol}^{\prime}$ of the dry wastes contaminated with radionuclides were combustible. Arthur D. Little, Inc.. contracted to design a process for handling these wastes, and after a study of available treat ment methods decid. ed that incineration was the best technique. A sum. mary of this study and the design for an incinerator. including loading system, furnace, and off-gas cleanup train, were submitted to ANL ir June 1950 . The incineration facility was placed in operation in July 1951 .

\section{Incineration (1951-1955)}

Pretreatment of Wastes. The wastes at ANL were sorted at the generating sites. Combustible wastes with $<50 \mathrm{mR} / \mathrm{h}$ activity were brought to the incinerator area in $0.028-\mathrm{m}^{3}\left(1-\mathrm{ft}^{3}\right)$ fiber drums, loaded onto steel pallets, and hoisted by crane to the loading platform of the incinerator.

Loading. Wastes were loaded into the furnace through a stainless-steel charging lock (Fig. 26) equipped with double doors to limit direct contact between the furnacte and the operating area.

Incinerator Design. The furnace (Fig. 26) was an all-welded, stainless-steel cylindrical unit. $1.525 \mathrm{~m}$ in diameter and $3.04 \mathrm{~m}$. high. Attached to the cylinder was a steel cone which tapered from the bottom of the cylinder into a $20.3-\mathrm{cm}$-diam opening through which the wet ash could be discharged.

The burning waste was supported in the furnace chamber by an arrangement of cast-iron grates which could be shaken. Removable plates on either side of the furnace allowed for grate removal and cleaning.

To ignite the charge and provide proper operating temperatures. the furnace was equipped with three
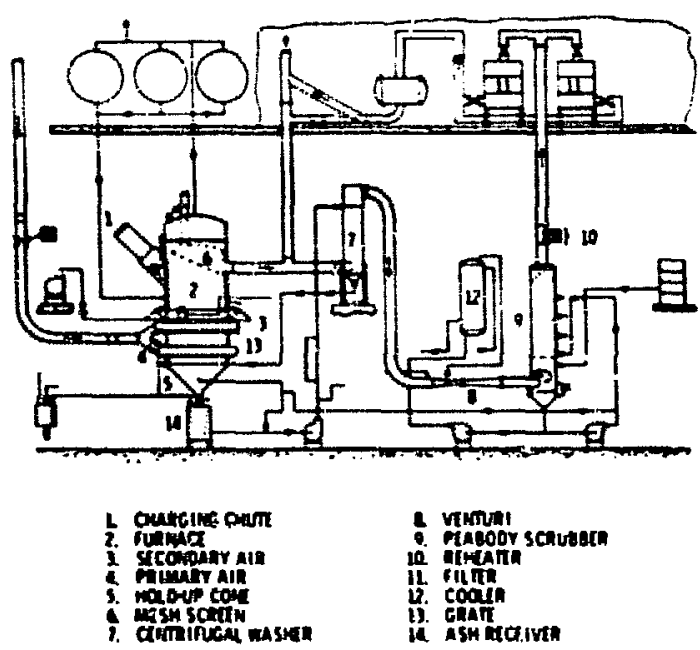

Fig. 26.

Incinerator at $A N L$. 
gas buiners located equidistant from each other above the grates. Primary air, which supplied most of the air for combustion, entered tangentially in four areas below the grate, while tangential secondary air entered through four ports above the grate.

The upper portion (and top) of the combustion chamber was surrounded by a iacket of carbon steel. This arrangement allowed the upper part of the furnace to be used as a boiler to remove heat from the combustion chamber.

A stainless-steel screen, placed at an angle across the furnace (Fig. 26), was used to catch large pieces of unburned material before the gases and entrained particulates passed into the exit duct. A rupture disk in the furnace roof served as a safety in case of a large. sudden increase in furnace pressure.

Monitoring devices included gas-burner safety controls, pressure recorders, temperature indicators, combustion-air flow-meters, liquid-flow indicators, liquid-level controllers, and viewing ports.

Off-Gas Cleanup. The off-gas cleanup train (Fig. 26) consisted of (1) a 10-plate SchreierBartolucci centrifugal gas washer for removal of particles $>10-\mu$ diam and for gas cooling, (2) a PeaseAnthony venturi scrubber for wetting and increasing the effective size of the small particles, (3) a Peabody gas scrubber for removing the wetted particles and for additional scrubbing and deentrainment of wetted particles, (4) a series of three electric reheaters, (5) an AEC filter (with two filters placed in parallel) for removal of fine particulates, and (6) an induced-draft fan.

An interconnecting liquid system (Fig. 26) was used between the liquid in the furrace-cone botton and various vessels in the scrubiver train. A cooles was operated to cool the liquid in the venturi and Peabody scrubber units.

Ash Removal. The ashes in the furnace dropped through the grates into the cone at the furnace bottom. The bottom of the cone coritained water which immediately quenched and wetted the ash. The ash passed downward through the water into an ash. collection burrel containing a flannel filter bag. When the bag was almost full, the valve at the bot. tom of the furnace was closed, the filter bag drained. and the ashes placed in storage.

Performance. Originally, only $\sim 311.3 / \mathrm{h}$ (11 $\left.\mathrm{ft}^{3} / \mathrm{h}\right)$ could be charged into the furnace. To increase the throughput, the heat-dissipating capacity of the bo:sr-jacket steam-water system was increased, the furnace-body insulation was removed, and a co: $v>c$ tion air-cooling duct installed. Then $\sim 283.651 \mathrm{i} / \mathrm{h}$ $\left(10-23 \mathrm{ft}^{3} / \mathrm{h}\right)$ could be charged, depending upon the type of waste. Assuming a density of $102 \mathrm{~kg} / \mathrm{m}^{3}(6.4$ $\left.\mathrm{lb} / \mathrm{ft}^{3}\right)$, a maximum throughput of $\sim 68.1 \mathrm{~kg} / \mathrm{h}(150$ ib $/$ h) was possible.

Combustion-chamber temperatures varied between 454.4 and $787.8^{\circ} \mathrm{C}$, with sn average of $621.1^{\circ} \mathrm{C}$. The maximum decontamination factor from feed to exhaust of the system was $2-3 \times 10^{t}$.

Problems. After 1 yr of operation, some buckling and weld separation had occurred on the circumference of the nonwater-jacketed poition of the furnace wall. The blanket insulation was removed and a galvanized iron duct was installed to cool the area by convection. The weld separations were reweldec. A steel baffle was installed inside tine furnace to prevent wastes from piling up, and additional furnace supports suare installed.

There was corrosion in the scrubber train, particularly between the first two scrubbing units where the gas was moist and relatively concentrated. A chemical analysis of a deposit indicated sulfates, which probably resulted from the burning of pape: wastes. There was plugging of liquid-lines, liquidlevel controllers, etc. The plugging was reduced by changing the source of liquid to a solution containing fewer solids and by using a fresh-water purge.

Foaming occurred in the Peabody tower, but when the distance between the gas-entry port and the liquid level was increased, foaming was reduced. The reduction in foaming decreased the carryover of entrained liquid into the filter. This, in turn, increased the lifetime of the filter to about ten 8-h days.

The furnace cone plugred with solids from noncombustibles in the wa: $t$ and from materials, such as plastic bottins and asphalt linings of waste containers, which melted, dropped through the grate, and resolidified in the water in the cone.

The bearings on the grate bars were too small and the grates sometimes stuck when they became hot. At least two major fires occurred in the filters, possibly because the reheaters furr.ished burning particles to the filter.

Shutdown. The incinerator operated for about 3 yr on a fairly regular basis, burning all combustible. radioactive plant waste until a cost-benefit analysis revealed that economical operation would require $24-\mathrm{h} /$ day incineration. Waste production could not meet this demand, and the unit was removed from service. 


\section{SOLREES}

"Report on Design for Volume Reduction of Com. bustible Radioactive Wasies by Incineration to Argonne National Laboratory," A.rthur D. Little report ALI-C-57867 (June 1950).

D. C. Hampson, E. H. Hykan, and W. A. Rodger, "Basic Operational Report of the Argonne Active Waste Incinerator," Argonne National Laburátory report ANL-5067 (February 1953).

R. Dennis and L. Silverman, "Radioactive Waste Incinerator Design and Operational Experience - A Review," in Seventh AEC Air Cleaning Conf., Oc. tober 10-12, 1961, Held at Brookhaven National Laboratory," AEC report TID-7627 (March 1962). pp. 419-421.

H. Kline, Manager, Central Maintenance: ANL. written communication.

\section{Las Alamos Scientific Laboratory (LASL), Los Alamos, NM.}

Incineration (1951-1953). In 1951 a large incinerator was constructed to burn some of the radionuclide-contaminated wastes generated at LASL.

Loading. The contaminated wastes were recpived at the incinerator site in cardboard boxes $(33 \mathrm{~cm} \mathrm{x}$ $33 \mathrm{~cm} \times 62 \mathrm{~cm}$ ). No sorting was done before the boxes were stacked into a charge and introduced into tile incinerator through a charging lock. The lock allowfod charging to take place without direct communication between the incinerator chamber and outside operating area.

Incinerator Design. The incinerator was designed to burn contaminated waste at a rate of 45.5-90.8 $\mathrm{kg} / \mathrm{h}$ and was similar in design to the BOMAEC-100 unit described in Sec. III-A-8 of this report. It had $E$ cylindrical combustion chamber and used tangential overfire and underfire air. A grate at the bottom served as a hearth for burning and also caught large noncombustible objects.

Off-Gas Cleanup. The unit had an extensive offgas cleanup system consisting of (1) a cyclone dust collector. (2) a spray cooler, (3) a Pease-Anthony venturi scrubber and separator, and (4) a two-stage. deep-pocket, dry fiber-glass filter.
Ast Remov'il. afte: the charge had burntod, or at the end of the day, the ashes and residue on the firing grate were dumped in the ash hopper by menual rotation of the grates. The linburned material, such as laineratory glassware, and mis. celluneous iron pieces, was caught on a strall grizz!y in the hopper, and the free ashes were dimped intc the receiving and holding tank.

Problems. Many problems we!e experienced' with this unit. One was the lack of gcorl ccrnibustion. Initially, only tangential underfire air wasi usert. Tangential overfire vas added in an atternpt to achieve bet ter sombustion, but combustion whs still poor. High temperatures were never obtairad despite auxiliary gas-firing. Maximum operating temseratures were probab!y $-426.7^{\circ} \mathrm{C}$.

Because of the poor combustion, tars, carbon, atc., were contained in the off-gases. Some of these unburned residues were not collected in the off-g $n$. cleanup. For example, when rubber gloves, wert da. ed to the waste, black smoke canne out of the atach.

The furnace was also subject to pressure trewrsions. It had not been designed for any overprsiante. or controlled release of overpiessure, so erisess pressure wouid be relieved back through thic leed system as well as into the main-rcom area. Bpicuse no secondary contairment cell had been gxe vided, constant decontamination of the rain rorm was necessary. By 1953, the area was so contaminated that incinerator operators had to be completely covered and wear respirators.

The off-gas cleanup was also unsatisfactory, Fiven if complete combustion had been achiever in the f urnace, off-gas cleanup would still have bean in. adequate. The cyclone removed very litt!e of the porticulate. To improve the system, water was added and the cyclone was converted to a wet systerl. Although there was some improvement, the cyclone's efficiency for particulate removal was still low. The Pease-Anthony venturi scrubter wisk also inefficient, partially because of the low pressite drop across the venturi; and it was not possilyle to opernte at a higher pressure drop because of isadequate tian capacity.

The filters also poseu probiems binause the cleanup train was located outside. The pases from the venturi did pass through a de-entrainer but, cince through, they continued to cool ir' colit weather. resulting in further condensetion. These drovs were deposited on the filters, the filters trersune clogged. and the material in the deep-pocicst filters sagged and broke away from the frame. Chnareling of the gases through the "free space" ther oxcurred. 
The grate arrangement was also a source of problems. Because there was no sorting of $n \cdot$ rials before charging, noncombustibles that were too large to pass through the grate would remain on top and clog the grate.

The contaminated water from the off-gas cleanup train was placed in storage tanks. After the incinerator was shut down, this water was transported to the liquid-waste treatment facility. The storage tanks, still contaminated, remain standing at their original location.

There was no arrangement for ash handling; contaminated ash built up in the bin and curroded it.

Shutdown. The LASL facility was never satisfactory. Only small amounts of contaminated wastes were run through (at irregular intervals) until it was decided to discontinue the operation because of the excessive contamination of the area and poor performance of the unit. It was never used as a production facility.

\section{SOURCES}

Industrial Hygiene Group, LASL, "Preliminary Reprort on the Los Alamos Incinerator Effluent Collector Performance," in Air Cleaning Seminar, Ames Laboratory, September 15-17, 1952, AEC report WASH-149 (June 1956), pp. 185-187.

R. Dennis and L. Silverman, "Radioactive Waste Incinerator Design and Operational Experience - A Review," in Seventh AEC Air Cleaning Conf., October 10-12, 1961. Held at Brookhaven National Laboratory," AEC report TID-7627 (March 1962), pp. 420-421.

H. Schulte, LASL, personal communication.

H. Jordan, LASL, personal communication.

\section{Bettis Atomic Power Laberatory, West Mimlin, PA}

Incineration (1953-1969). From 1953 until February 1969, low-level combustible wastes were incinerated at Bettis. The first incinerator was purchased in 1953 for \$5k and a second, almost identical. unit was purchased in 1959 for $\$ 4 k$.

Pretreatment and Loading of Wastes. The wastes ware separated into combustible and non- combustible categories. Combustible wastes with an activity $<40 \mathrm{mR} / \mathrm{h}$ (as measured on contact with the outside of the steel, 242-(drums) were sent to the incineration area. There the contents of the drum were again sorted to insure that no significant quantity of flammable solvent was present.

Furnace operation began with the addition of the contents of about four drums. The off-gas cleanup system was placed in operation and the waste ignited manually. The contents of about 12 more drums were usually top-loaded into the combustion chamber during the day.

Incinerator Design. In the basic design, each incinerator had a cylindrical firebrick-lined combustion chamber with a steel-shell body. Air for combustion was added tangentially into the chamber. The waste burned on a grate, and the ashes dropped to the bottom of the chamber.

Off-Gas Cleanup. The final off-gas cleanup train included (1) a fog spray-nozzle section for cooling, (2) a wet dust collector (rotoclone), (3) a damper, and (4) a fan. The liquid used in the rotoclone and fog spray was circulated through a filter to remove particles larger than $5 \mu$, and neutralizing themicals were added to control $\mathrm{pH}$.

Ash and Liquid Removal. The ash from the :ombustion chamber was collected in $242 . /$ drums and treated as low-level noncombustible waste. The liquid from the cleanup system was drained periodically and the system cleaned.

Problems. Several modifications to the design of the original unit were made to achieve better combustion and to reduce corrosion. For example. the combustion chambers were lined with hightemperature, insulating furnace-brick, which allowed operation at higher temperatures, hence more complete combustion.

The rotoclones were of stainless steel D-319, rather than mild steel. A cooling unit was placed before the rotoclones and a system was installed for $\mathrm{pH}$ control and particulate removal in the liquid.

Shutdown. As the two units got older, maintenance requirements (caused mainly by corrosion) became more costly and time-consuming. Finally, in February 1969 the equipment was removed from service and the wastes were treated by methods other than incineration. 


\section{SOURCES}

"Solid Radioactive Waste Disposal, January 1, 1965 . January 1, 1970," Bettis Site, Attachment A to WAPD-CL(RA)-25.

W. Lennemann et al., "Incineration of Radioactive Solid Wastes," AEC report WASH-1168 (August 1970), p. 17.

\section{Shippingport Atomic Power Station, Ship- pingport, PA.}

Early Incineration Facility. At one time an incinerator for combustible wastes contaminated with radionuclides was operated at Shippingport. The basic problem at this installation was the inability of the incinerator to maintain a temperature high enough to achieve eomplete combustion. The unit was shut down, and there is now no incineration of wastes at Shippingport.

\section{SOURCES}

"Report on Sol. " Radioactive Waste Management at Shippingport Atomic Power Station," Duqueine Light Co. informal repcrt.

L. Lennemann et al., "Incineration of Radioactive Solid Wastes," AEC report WASH-1168 (August 1970), p. 17.

T. D. Jones, Superintendent, Shippingport Atomic Power Station, written communication.

7. United Nuclear Industries, Inc., Richland, WA. In the 1950's through the early 1970's the General Electric Co., followed in 1964 by Douglas United Nuclear, Inc., carried on operations at Richland that resulted in the generation of combustible wastes slightly contaminated with radionuclides. Several years ago United Nuclear Industries, Inc., assumed operation of the facility. Until about $4 \mathrm{yr}$ ago, some wastes at this facility were incinerated.

The wastes were sorted before incineration. Combustible wastes, except those contaminated with (1) transuranic radionuclides, (2) beryllium, or (3) ${ }^{60} \mathrm{Co}$ concentrations greater than $1 \mathrm{mCi} / \mathrm{g}$ of matrix, were selected for possible incineration.

a. Open-Pit Incineration. In 1949, the 1950 's, and the early 1960's, combustible wastes were oc- casionally burned in open burial trenches and deep pits. At that time there was no detectable environmental contamination; however, some empty oil drums exploded during burning in 1960 and trench-type burning was discontinued.

b. Incinerators. In 1967 a waste incinerator was placed in operation at one of the burial areas. It was a natural-draft incinerator that was installed above ground over an ash pit.

In 1968 a similar incinerator was placed in rperation at another burial area. This incinerator was modified to permit burning in the ash pit. The modification allowed the operator to fill the pit with bcriss instead of burning them two or three at a time on the incinerator grating above the pit. To improve combustion, air was pumped to the bottom of the ash pit through a pipe. No provision was made for off-gas treatment.

With this equipment, not all the smoke went up the stack. High temperatures warped the doors, and smoke poured out of all unsealed cracks. In addition, quantities of black smoke from sisal kraft paper in the wastes were emitted from the stacks of the incinerators.

During incineration of $>57 \mathrm{~m}^{3}\left(>2000 \mathrm{ft}^{3}\right)$ of wastes, with an activity of $1-10 \mathrm{mR} / \mathrm{h}$ at the carton surface, the release rate never exceeded $5 \times 10^{-9}$ $\mu \mathrm{Ci} / \mathrm{cm}^{3}$ in the stack plume.

For the past $\sim 4 \mathrm{yr}$ the incinerators have not been operated. It was considered to be too expensive to install a conventional incinerator and to treat the offgases from this type of unit. In addition, it was decided that the time required tc sort and handle these wastes made the treatment uneconomical. These types of wastes are now being sent directly to the burial ground.

\section{SOURCES}

C. D. Corbit, "Incineration, Compaction, Segregation, and Burial of Solid Radicactive Wastes," Douglas United Nuclear report DUN-6748 (February 1970).

T. E. Dabrowski, United Nuclear Industries, Inc., personal communication.

L. Brinkman, "Preliminary Engineering Report and .Justification, Contaminated Waste Incinerator," Douglas United Nuclear report DUN-754 (March 1966). 
8. Bureau of Mines, Combustion Research Section, Pittsburgh, PA. In the early 1950's the Bureau of Mines was given AEC funds to develop a convenient, economical, and safe means for disposing of low-level combustible wastes. On the basis of some preliminary tests on a 242-1 (55-gal) drum with various design parameters, air-flow rates, etc., the Bureau developed an incinerator known as BOMAEC-30.

\section{a. Initial BOMAEC-30}

Incinerator Design. The initial BOMAEC incinerator (Fig. 27) consisted of a cylindrical combustion chamber of steel. Air for oxidation entered as tangential overfire air. An exhaust fan drew combustion air into the annular shell surrounding the burning chamber and exhausted hot combustion gases through the centrally located outlet pipe above the burning chamber.

The cyclone design of the incinerator with overfire tangential air feed was supposed to give good combustion in a single chamber and increase retention of solids.

Off-Gas Cleanup. Effluent gas passed downward through a water-cooled heat exchanger

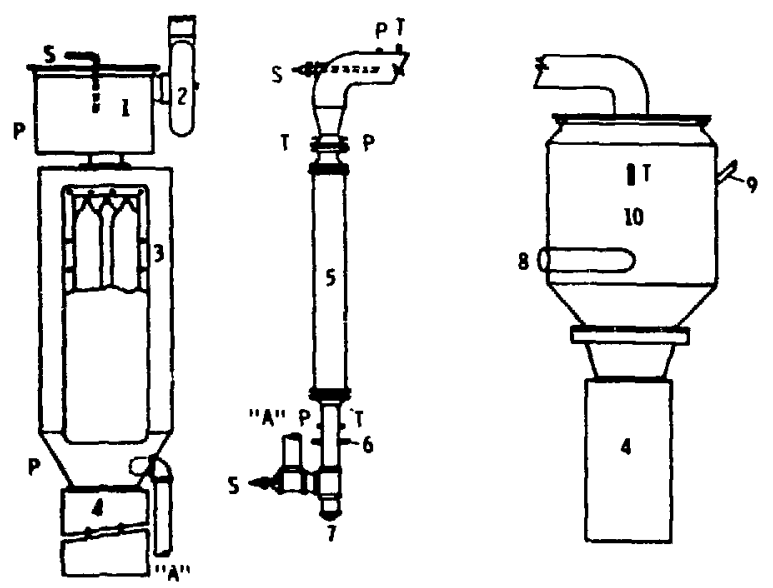

NOIE: P. 5. \& T INDICATE TEST POINTS FOR STATIC PRESSURE, SOLIOS SAMPLES, \& TEMPERATURE

$\begin{array}{ll}\text { 1. AEC FIL TER HOLOER } & \text { 7. DRAIN PLUG } \\ \text { 2. EXHAUSI FAN } & \text { 8. ARR INLET } \\ \text { 3. BAG HOUSE } & \text { 9. SIGHT GLASS } \\ \text { 4. ASH DRUM } & \text { 10. BURNING CHAMBER } \\ \text { 5. ROSS UATER TUBE } & \\ \text { HEAT EXCHANGE } & \\ \text { 6. } \text { and } \mathrm{CO}_{2} \text { SAMPLING PORTS } & \end{array}$

Fig. 27.

Initial BOMAEC-30 incinerator. and entered the base of the baghouse (Fig. 27) at temperatures $<260^{\circ} \mathrm{C}$. After filtering through seven glass-fabric bags, the gas entered an empty compartment intended to house AEC-type, absolute filters which were to be installed when combustion and other gas-treatment facilities were proven satisfac. tory.

Performance. In 1954 the AEC asked the Harvard University Air Cleaning Laboratory (ACL) to conduct stack-sampling and gas-cleaner evaluation tests on the BOMAEC-30 and the gas cleanup system. Tests were run in which sawdust was charged to the combustion chamber, the charge ignited, and the results monitored. In a progress report, issued in January 1955 , many problems were mentioned, both in the air-cleaning system and combustion process.

b. First Modification, BOMAEC-30. Because of the test results obtained from the initial design of the BOMAEC-30, it was decided to increase the depth of the combustion chamber, adjust the air supply, and spray-cool the gases. Again, sampling teets were performed by ACL personnel in 1955. In addition to sawdust, rubbish was also incinerated. Test results again indicated an unsatisfactory system.

c. Second Modification, BOMAEC-30. To improve the performance of the incinerator, it was decided to add auxiliary air at the top of the burning chamber and also to test the use of an auxiliary natural-gas air burner. Again, the facility was tested by ACL personnel.

After initial testing (when these additional modifications had been made), the incinerator was shipped to ACL for further testing. A portion of the top cover was hinged to swing upward for easier waste loading. Problems encountered in the tests at ACL included rapid plugging of the glass bags and warping of materials, both of which resulted in excessive air leakage at several points in the system. Gas temperatures did not exceed $426-482^{\circ} \mathrm{C}$ at any time; the gas flow within the burning chamber lacked the characteristic spiral pattern; and the flame color observed through the view-port was a dull, smoky orange.

Three glass bags ripped at the seams and, even with replacements, resistance could not be kept below $2490 \mathrm{~Pa}$ (10 in. water gauge). At this point, it appeared that glass bags would not be suitable unless some precleaning unit was used to screen out a good part of the carbonaceous material. 
d. Final Design, BOMAEC-30. The final recommended design of the BOMAEC-30 system is shown in Fig. 28. An ACL analysis of this design indicated that the BOMAEC-30 was not a workable unit.

e. BOMAEC-160. The Bureau of Mines built a larger version of the BOMAEC-30 that was called the BOMAEC-100 (Fig. 29). ACL tests of this unit gave results similar to those ubtained for the BOMAEC-30. Further details of the incinerators and the tests conducted are available from the sources cited.

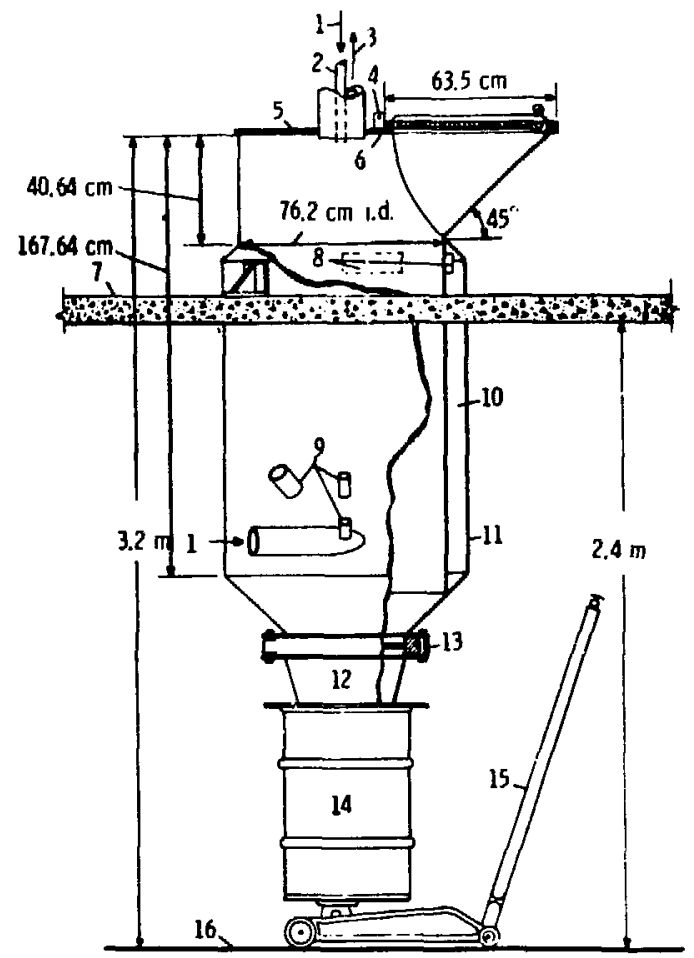

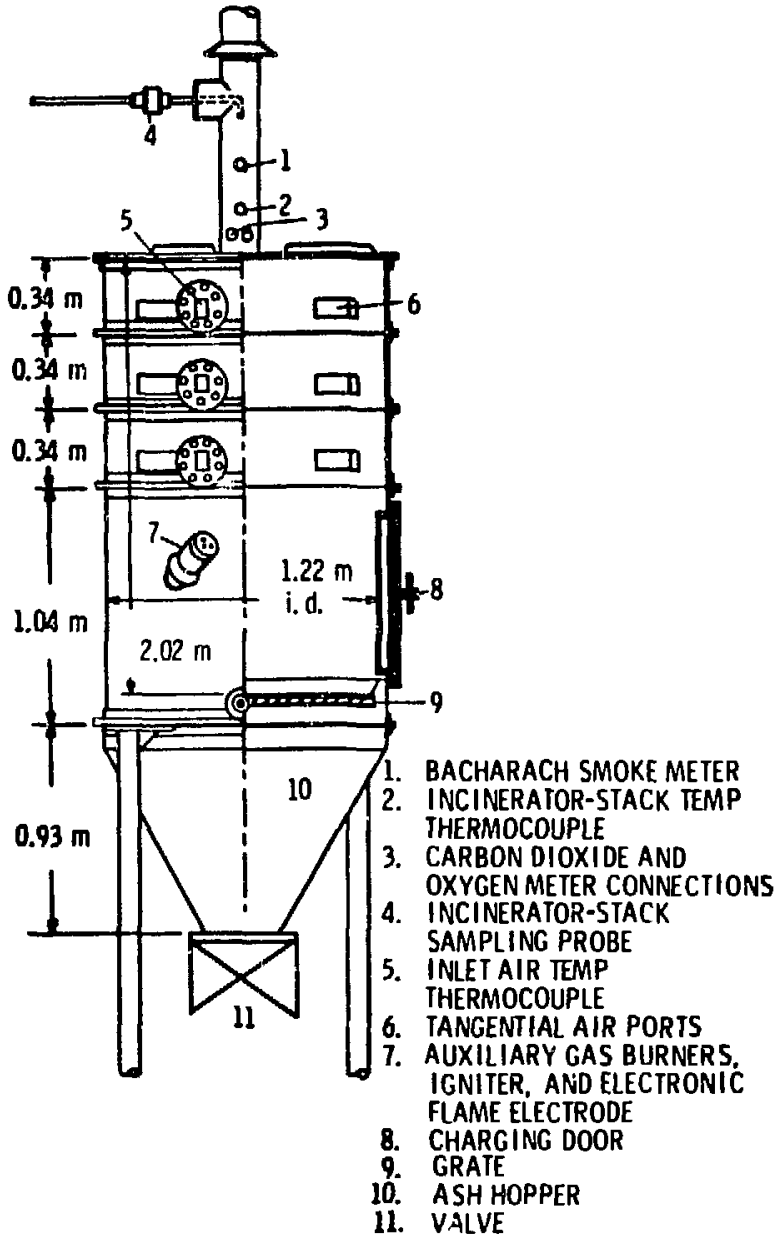

Fig. 29.

BOMAEC-100 incinerator.

\section{SOURCES}

R. Corey, "Process Variable Study of Incineration Using Tangential Overfire Air," in Air Cleaning Seminar, Ames Laboratory, September 15-17, 1952, AEC report. WASH-149 (March 1954), pp. 154-169.

R. C. Corey and C. H. Schwartz, "Incinerator for Solid Combustible Wastes Containing Low-Level Radioactivity," Bureau of Mines Report of Investigations RI-6083 (1962).

Fig. 28.

Final design of EOMAEC-30 incinerator.

R. Dennis, C. Billings, and L. Silverman, "Performance of Gas Cleaning Equipment for BOMAEC-30 
Incinerator," Harvard School of Public Health report (January 1955).

R. Dennis, W. Samples, and L. Silverman, "Stack Effluent Tests on BOMAEC-30 and BOMAEC-100 Incinerators," Harvard School of Public Health report (September 1955).

R. Dennis and L. Silverman, "Summary Report on Performance of Air Cleaning System for US Bureau of Mines BOMAEC-30 Incinerator," AEC report NYO-841-2 (December 1964), p. 24 and Appendixes.

R. Dennis and L. Silverman, "Radioactive Waste Incinerator Design and Operational Experience - A Review," in Seventh AEC Air Cleaning Conf., October 10-12, 1961, AEC report TID-7627 (March 1962), pp. $419-422$.

R. Dennis, F. Muller, E. Kristal, and L. Silverman, "Special Incineration Studies - Institutional Design," in Sixth AEC Air Cleaning Conf., July 7-9, 1959, AEC report TID-7593 (October 1960), pp. 344364.

R. Dennis, C. Billings, W. Samples, and L. Silverman, "Gas Cleaning Studies of U. S. Bureau of Mines Incinerators. Stack Effluent Tests on BOMAEC-30 and BOMAEC-100 Incinerators," in Fourth AEC Air Cleaning Conf., November 1955, AEC report TID-7513, Pt.1 (June 1956), pp. 219-245.

9. Harvard Air Cleaning Laboratory (ACL), Boston. During testing of the BOMAFC incinerator, personnel from ACL made several suggestions for improvement in the incinerator design. They also modified a domestic-type incinerator (Incinor) and conducted tests on this unit. As a result of experience with these incinerators, it was decidid to construct an incinerator at $\mathrm{ACL}$.

a. $A C L-I$ Incinerator. The first experimental incinerator consisted of a 242-/ (55-gal) drum lined with firebrick. The unit was provided with a cleanout port and grate. Air for combustion included tangential overfire air introduced at a single entry point. A charging and predrying section was located above the combustion area.

Although better combustion and proportionately greater burning rates were realized with the ACL-I incinerator than with the BOMAEC-30 and Incinor units, the overhead predrying and charging system pressented operational problems. Dumping of the bagged sawdust charged into the burning chamber occasionally extinguished the flame. Because residual chamber heat was sufficient to distill volatile materials, re-ignition at times produced minor explosions. In addition, there was premature ignition of charges stored in the predrying chamber. Although ACL personnel believed that the charging system could have been made operable, the necessary modifications would have led to additional cost and complexity.

b. ACL-II Incinerator. On the basis of tes . results from and operating experience with ACL-I, a second incinerator called ACL-II was constructed. This incinerator, shown in Fig. 30, used the same kind of burning chamber as ACL-I. However, a side charging door was located slightly above the grate. A twopronged sliding fork was inserted in the dcor so that wet charges could be supported along the wall of the combustion chamber. When the fork was withdrawn, the dried charge fell to the grate and burned. A cylindrical, brick-lined afterburner chamber was mounted directly above the primary burning chamber. A tangential inlet at the base of the afterburner permitted the addition of auxiliary combustion air or gas. The exit was placed on the afterburner in such a position as to maintain the spiral gas flow in the system.

Dilution air was added at the gas-exit point of the incinerator. The air not only cooled the combustion gases but also seemed to reduce tar concentrations in the effluent.

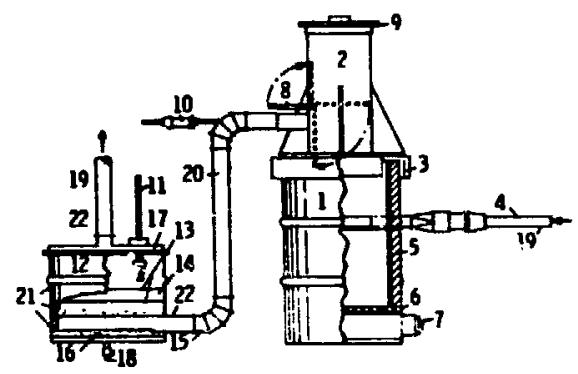

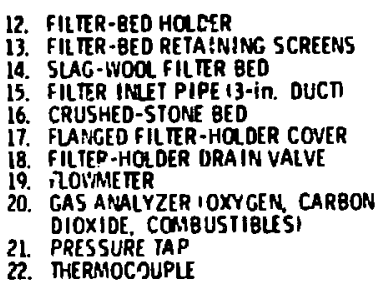

Fig. 30.

$A C L-I I$ incinerator. 
The ACL-II provided better combustion than did the BOMAEC incinerators and ACL-I. In addition, it was the only device that could be used to incinerate wet charges without auxiliary gas-firing. Personnel theorize that the presence of moisture may have retarded the volatilization of tar products, thus affording a better chance for more uniform burning.

Fiber filters used to clean the off-gases from ACLII gave problems, so it was decided to try the use of an electrostatic precipitator. Some problems, including magnetic-field distortions which caused sparking, deposits on the grounded electrodes, etc., were found with the pzecipitator.

Specifications for an instituronis type incinerator were published, and design specifications were prepared for a $22.7-\mathrm{kg} / \mathrm{h}(50-\mathrm{lb} / \mathrm{h})$ incineration-gas cleaning system, known as ACL.50, which was to be installed in the Army Nuclear Defense Laboratory at Edge'wood, MD.

\section{SOURCES}

R. Dennis, F. Müller, E. Kristal, and L. Silverman, "Special Incineration Studies - Institutional Design." in Sixth AEC Air Cleaning Conf., July 7-9. 1959. AEC report TID-7593 (October 1960), pp. 344364.

R. Dennis and L. Silverman, "Radioacíive Waste Incinerator Design and Operational Experience . A Revicw," in Seventh AEC Air Cleaning Conf.. October 10-12, 1961. Held at Brookhaven National Laboratory." AEC report TID-7627 (March 1962). pp. 416-453.

10. US Army Nuclear Defense Laboratory, Edgewood Arsenal, MD. In the early 1960's the Department of the Army assigned the responsibility for radioactive waste disposal to the US Army Eastem Chemical Depot at Edgewood Arsenal. The wastes included large volumes of low-level radioactive combustibles, among which were large animal carcasses.

A program. cosponsored with ACL. was begun to design, fabricate, and test a $22.7-\mathrm{kg} / \mathrm{h}(50-\mathrm{lb} / \mathrm{h})$ in. cinerator to be used at Edgewood Arsenal. In 1963 the incinerator was installed.

\section{Incineration Facility}

Loading. In the Edgewood incinerator, wastes were introduced into the main combustion chamber as packaged charges of $2.7-4.5 \mathrm{~kg}(6-10 \mathrm{lb})$ each through a totally enclosed charging lock (Fig. 31). A three-pronged sliding fork, inserted through the loading door, permitted temporary suspension of wet charges above the grate so that they could be dried hefore being placed on the grate for incineration.

Incinerator Design. The incinerator consisted of a primary and secondary combustion chamber lined with insulating-type refractory. As shown in Fig. 32, a grate was located in the lower part of the primary chamber.

Primary overfire air was admitted tangentially into the primary combustion chamber from two openingz. Secondary combustion air also was adfintted tangentially through an opening several cen. timeters above the base of the secondary combustion chamber.

Continuous gas-firing could be used in both com. bustion chambers. Burners were used to maintain the desired operating temperatures and to preheat the incinerator before waste-charging began.

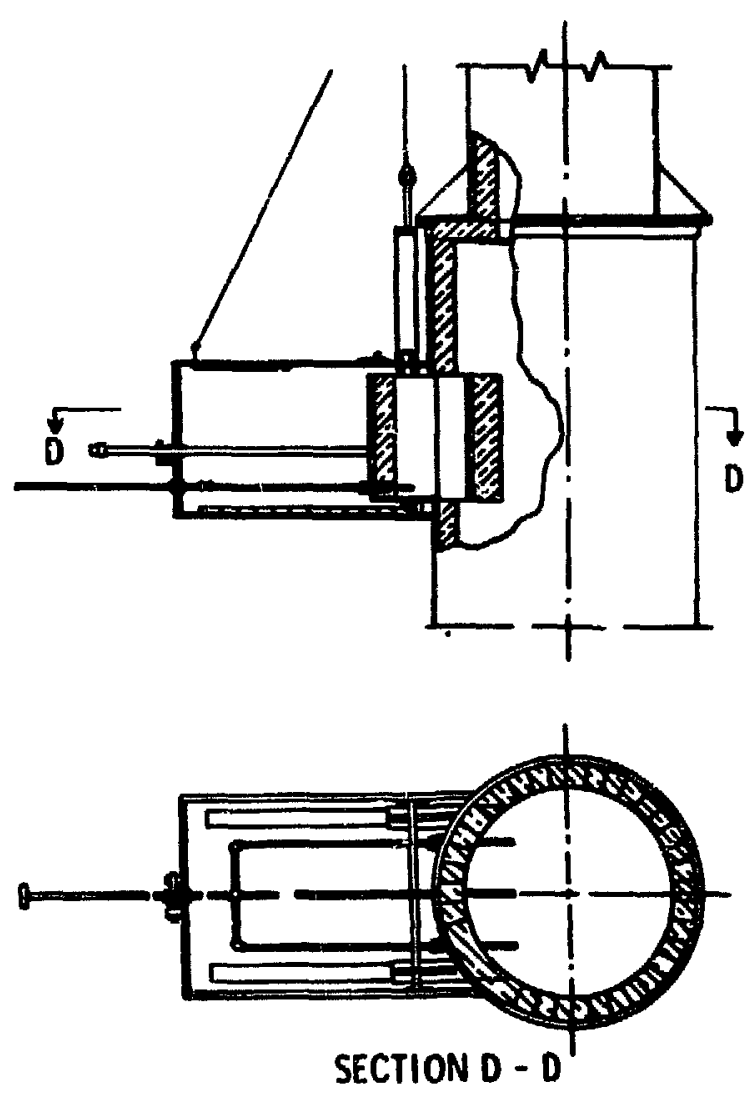

Fig. 31 .

Charging lock of Edgewood Arsenal incinerator. 


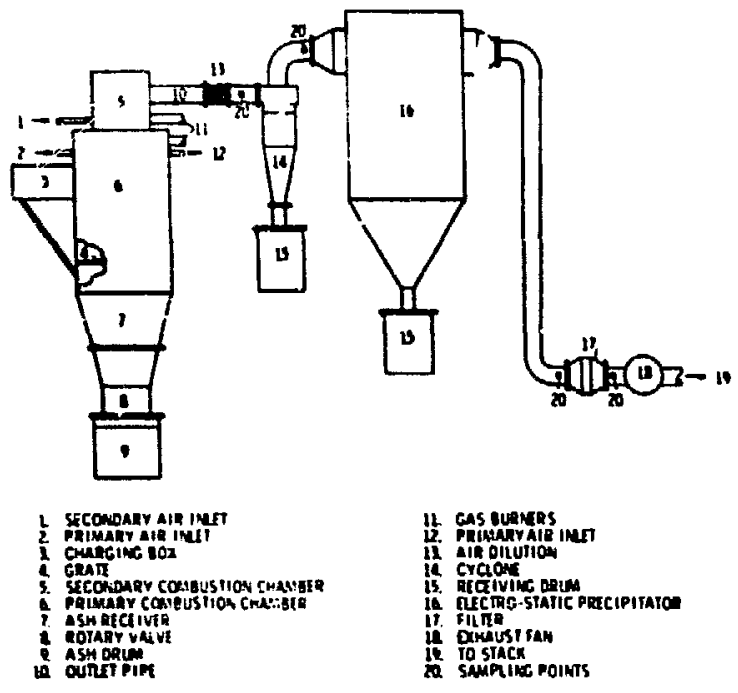

Fig. 32.

Incinerator at Edgewoud Arsenal.

$H^{\sim} t$ gases exited the secondary ccmbustion cha 'jer tangentially and were cooled by dilution with ambient air before entry into the gas-cleaning equipment.

Off-Gas Cleanup. The off-gas cleanup system (Fig. 32) consisted of a cyclone, electrostatic precipitator, and filter bank of two high-efficiency mineral-fiber filters.

Residue Removal. The ashes from the wastes incinerated in the primary combustion chamber fell into a conical ash receiver at the bottom of the chamber. A rotary valve allowed discharge of the ash into a drum. A hydraulic jack was used to maintain a tight air seal between the drum rim and the rotary valve.

The dust collected by the cyclone was discharged to a drum through use of a slide valve, and a slide valve was used to discharge into another drum the material collected by the electrostatic precipitator. The precipitator was cleaned only when the facility was not operating.

Performance. Before being used to incinerate radionuclide-containing wastes, the system was used for a series of tests on cold wastes. Initially, the airdilution unit didn't operate satisfactorily, but it was redesigned and better results were obtained.

The system was run under various burneroperating conditions, air-flow rates and angles of entry, waste-charging rates, operating conditions for the electrostatic precipitator, etc. Results of these tests can be found in the sources cited.

Once the optimum operating conditions for the facility had been defined by engineering evaluation. a radiological evaluation was made using ${ }^{89} \mathrm{Sr}$ and 131 I. When sawdust contaminated with ${ }^{89} \mathrm{Sr}$ at the $10-\mu \mathrm{Ci} / \mathrm{kg}$ level was incinerated, a significant portion of the ${ }^{89}$ Sr became "fixed" to the interior refractory walls of the incinerator and to the discharge hopper. Subsequent cold runs removed some of the activity from the walls as a result of the "scrubbing" effects of the swirling particulate, and also removed some activity from the discharge hopper. Usually, four cold runs were sufficient to decontaminate the refractory walls to a point where filter samples from the next hot run would not be significantly influenced by residual surface activity. The refractory did not approach a "saturation" condition. Table VI summarizes the material balance for ${ }^{89} \mathrm{Sr}$. Table VII indicates the amount of reduction in activity by each cleanup device.

The activity concentration discharged to the atmosphere was also measured. At irput activities to the incinerator of $10-20 \mu \mathrm{Ci} / \mathrm{kg}$ no activity above background was measured. When $150 \mu \mathrm{Ci} / \mathrm{kg}$ were charged to the incinerator, an activity of $(4.4 \pm 3.8)$ $x 10^{-12} \mu \mathrm{Ci} / \mathrm{cm}^{3}$ was measured.

Probleins. One problem was that the charging lock warped and failed to function properly. Problems were also experienced with the grate. When the holes in the grate were too small, the ash failed to fall through. When the holes were made larger, unburned material fell through the holes into the ash bin. Plastics melted on the grate and dripped into the ash receiver. The grate also warped during operation of the incinerator. The discharge-valve arrangement for ash discharge into the ash drum also warped, causing containment problems.

At first, poor mixing resulted in poor combustion, but this condition was improved.

The electrostatic precipitator tended to spark excessively at normal operating voltages. However, when the voltage was lowered, the efficiency of the unit was reduced. The building was too small to house the incinerator and to store the wastes.

In addition to these operational problems, funding problems and a license requirement resulted in a decision to shut down the facility.

\section{SOURCES}

E. W. Bloore and D. G. Lachapelle, "A Radioactive Waste Incinerator," in Eighth AEC Air Cleaning 
TABLE VI

\section{ACCOUNTABILITY OF ${ }^{89} \mathrm{Sr}$ IN EDGEWOOD ARSENAL INCINERATOR ${ }^{\mathrm{a}}$}

\begin{tabular}{|c|c|c|c|c|}
\hline $\begin{array}{l}\text { Input } \\
\text { Activity } \\
(\mu \mathrm{Ci} \text {. }\end{array}$ & $\begin{array}{c}\text { Released } \\
\text { as Ash } \\
(\%) \\
\end{array}$ & $\begin{array}{c}\text { Released } \\
\text { as Particulate } \\
\text { (\%) } \\
\end{array}$ & $\begin{array}{c}\text { Absorbed by } \\
\text { Refractory } \\
\text { (\%) } \\
\end{array}$ & $\begin{array}{c}\text { Retained by } \\
\text { Incinerator } \\
\text { (\%) } \\
\end{array}$ \\
\hline 94.2 & 45.2 & 2.4 & 52.4 & 97.6 \\
\hline 186.3 & 33.9 & 1.3 & 64.8 & 98.7 \\
\hline 299.2 & 27.3 & 1.0 & 71.7 & 99.0 \\
\hline 389.6 & 15.9 & 1.4 & 82.7 & 98.6 \\
\hline 483.2 & 40.4 & 1.0 & 58.6 & 99.0 \\
\hline 546.4 & 23.6 & 1.1 & 75.3 & 98.9 \\
\hline 638.0 & 17.4 & 1.8 & 80.8 & 98.2 \\
\hline 726.0 & 30.0 & 1.2 & 68.8 & 98.8 \\
\hline 806.4 & 31.4 & 1.3 & 67.3 & 98.7 \\
\hline 898.6 & 29.7 & 1.5 & 68.8 & 98.5 \\
\hline 985.6 & 37.4 & 1.2 & 61.4 & 98.8 \\
\hline 1100.8 & 29.4 & 1.8 & 69.4 & 98.2 \\
\hline 1188.0 & 29.9 & 1.2 & 68.9 & 98.8 \\
\hline 1272.0 & 21.3 & 2.4 & 76.3 & $\$ 7.6$ \\
\hline 1360.8 & 22.6 & 3.9 & 73.5 & 96.1 \\
\hline 1466.4 & 36.1 & 3.1 & 60.8 & 96.9 \\
\hline 1552.4 & 28.6 & 2.1 & 69.3 & 97.9 \\
\hline 1624.4 & 29.5 & 1.5 & 69.0 & 98.5 \\
\hline 1732.0 & $\mathbf{b}$ & 1.7 & b & b \\
\hline 1820.3 & 30.0 & 1.9 & 68.1 & 98.1 \\
\hline
\end{tabular}

Conf., October 22-25, 1963, AEC report TID-7677 pp. 331-344.

R. Dennis, W. Kyritsis, and E. W. Bloore, "An Evaluation Program for Radioactive Waste Incineration;" Army Nuclear Defense Laboratory report NDL-TM-8 (March 1963).

D. G. Lachapelle, J. L. Tarbox, and D. L. Goff, "Evaluation Program for Radioactive Waste Incineration. Suppiement. Pts. I-III," Army Nuclear Defense Laboratory report NDL-TM-24 (October 1965).

D. Lachapelle, "An Engineering Evaluation of a Radioactive-Waste Incinerator," in Ninth AEC Air Cleaning Conf., September 13-16, 1966, AEC report CONF-660904, Vol. 1, pp. 509-569.

R. Denris and L. Silverman, "Air Cleaning Studies Progress Report for January 1, 1963 to June 30, 1964, AEC report NY0-841-1, pp. 38-40.
E. Gloyna, Dean, School of Engineering, University of Texas, personal communication.

E. Wright, Ballistics Research Laboratory, personal communication.

11. Other US Facilities Operated in the Early 1960's for Incineration of Uranium-Containing Wastes. During the early 1960 's, several AEC contractors, in addition to the ones already discussed, burned wastes contaminated with depleted, natural, or various levels of enriched uranium. In general, the waste consisted of papers, rags, gloves, towels, and boxes. A study made of incinerators used by AEC contractors in the early 1960's is reported in Health Phys. 10, 237-241 (1964).

a. United Nuclear Corp., Montuille, CT. The United Nuclear incinerator had a rated capacity of 


\section{EFFICIENCY OF CLEANUP FACILITIES (EDGEWOOD ARSENAL) ${ }^{a}$}

\begin{tabular}{|c|c|c|c|}
\hline $\begin{array}{l}\text { Input Activity } \\
\text { to Incinerator } \\
(\mu \mathrm{C})\end{array}$ & $\begin{array}{c}\text { Inlet Activity } \\
\text { to Cyclone } \\
(\mu \mathrm{C})\end{array}$ & $\begin{array}{c}\text { Inlet Activity } \\
\text { to Precipitator } \\
(\mu \mathrm{Ci}) \\
\end{array}$ & $\begin{array}{l}\text { Inlet Activity to } \\
\text { Absolute Filter } \\
\left(\mathbf{1 0}^{-2} \boldsymbol{\mu C i}\right)\end{array}$ \\
\hline 94.2 & 2.22 & 0.58 & 1.39 \\
\hline 186.3 & 2.46 & 0.71 & 1.34 \\
\hline 299.2 & 2.96 & 1.03 & 1.72 \\
\hline 389.6 & 5.54 & 1.79 & 3.27 \\
\hline 483.2 & 5.00 & 0.91 & 4.68 \\
\hline 546.4 & 5.98 & 2.27 & 4.41 \\
\hline 638.0 & 11.55 & 3.36 & 4.36 \\
\hline 726.0 & 8.86 & 1.95 & 5.62 \\
\hline 806.4 & 10.60 & 2.57 & 7.70 \\
\hline 898.6 & 13.65 & 3.93 & 6.85 \\
\hline 985.6 & 12.15 & 3.58 & 13.3 \\
\hline 1100.8 & 19.85 & 5.90 & 10.2 \\
\hline 1188.0 & 13.75 & 1.88 & 21.6 \\
\hline 1272.0 & 30.5 & 4.43 & 18.5 \\
\hline 1360.8 & 52.5 & 5.46 & 7.38 \\
\hline 1466.4 & 44.9 & 7.00 & 27.4 \\
\hline 1552.4 & 32.0 & 8.27 & 26.3 \\
\hline 1624.4 & 24.4 & - & - \\
\hline 1732.0 & 28.9 & - & $\cdot$ \\
\hline
\end{tabular}

$95.3 \mathrm{~kg} / \mathrm{h}(210 \mathrm{lb} / \mathrm{h})$. It had an auxiliary fly-ash settling chamber followed by a short stack. In the stack, activities in the gas averaged $2.3 \mathrm{dpm} / \mathrm{m}^{3}$.

b. Metals and Contrals, Attleboro, MA. At Metals and Controls, all waste that was combustible and known to be contaminated was incinerated. The incinerator was a unit with a throughput rating of $\sim 90.7 \mathrm{~kg} / \mathrm{h}(200 \mathrm{lb} / \mathrm{h})$. The gases passed through a cyclone before discharge through a low stack. In the discharge stream a few feet from the stack, an activity level of $8.9 \mathrm{dpm} / \mathrm{m}^{3}$ was measured.

c. Pratt and Whitney Aircraft, Middletown, CT. The Pratt and Whitney incinerator had a rated capacity of $272.2 \mathrm{~kg} / \mathrm{h}(600 \mathrm{lb} / \mathrm{h})$. The off-grses discharged directly to a stack. When lower activity wastes were incinerated, activity levels of 7.6 $\mathrm{dpm} / \mathrm{m}^{3}$ were measured in the stack.

High-activity wastes were burned in a $242-1$ drum. The effluent gases discharged through the same stack that served the incinerator. When the drum incinerator was in use, activity levels of $530 \mathrm{dpm} / \mathrm{m}^{3}$ were measured. Approximately $99.1-99.98 \%$ of the activity remained in the ash.

\section{SOURCE}

P. Loysen. Discussion in Seventh AEC Air Cleaning Conf., October 10-12, 1961, AEC report TID-7627 (March 1962), pp. 454-456.

12. General Electric Atomis Power Equipment Department, San Jose, CA. The General Electric facility in San Jose produced comiustible wastes slightly contaminated with uranium. The wastes included paper, polyethylene bags, and paper containers. In February 1960 an incinerator was placed in operation to treat thesa wastes.

\section{Incineration Facility}

Loading. The cardboard s.aste-collection boxes were fod in. io the incinerator through an air lock 
which connected to the guillotine charging door of the furnace. An automatic ventilation system insured inward flow of air at all times. During loading, the operator wore a half-mask respirator and protective clothing.

Incinerator Design. The incineration system was located outside, mounted on a concrete pad hav. ing a lip on all sides and equipped with drains connected to the liquid-waste treatment area. The incinerator (Fig. 33), containing three chambers, had a rectangular shape, $1.216 \mathrm{~m} \times 0.915 \mathrm{~m} \mathrm{x} 1.60 \mathrm{~m}$, and was designed for firing $45.5 \mathrm{~kg} / \mathrm{h}(100 \mathrm{lb} / \mathrm{h})$. It had a 10.16-cm (4-in.) firebrick lining. The furnace was allowed to heat up for $1 \mathrm{~h}$ before wastes were charged. Proper operating temperatures were maintained by gas burners. The outlet temperature from the incinerator was estimated to be $760-816^{\circ} \mathrm{C}$.

Off-Gas Cleanup. From the furnace, the offgases were fed through a baffled water-spray system to cool them below $315^{\circ} \mathrm{C}$. The water system was equipped with a recirculating pump, a tank, and a water make-up system. When the incinerator was shut down after a run, the recirculating-system filters v.ere removed and cleaned to avoid uranium build-up.

After having been cooled, the gases passed through two prefilters in parallel and two absolute filters in parallel. When $498 \mathrm{~Pa}$ (2 in. water gauge) of pressure drop occurred, the filter was changed. On the average, $\sim 140$ boxes of waste were burned before filter replacement was necessary. The gases, after passing through the filter, exited past a continuous air sampler before exhausting to the ambient air through the induced-draft fan.

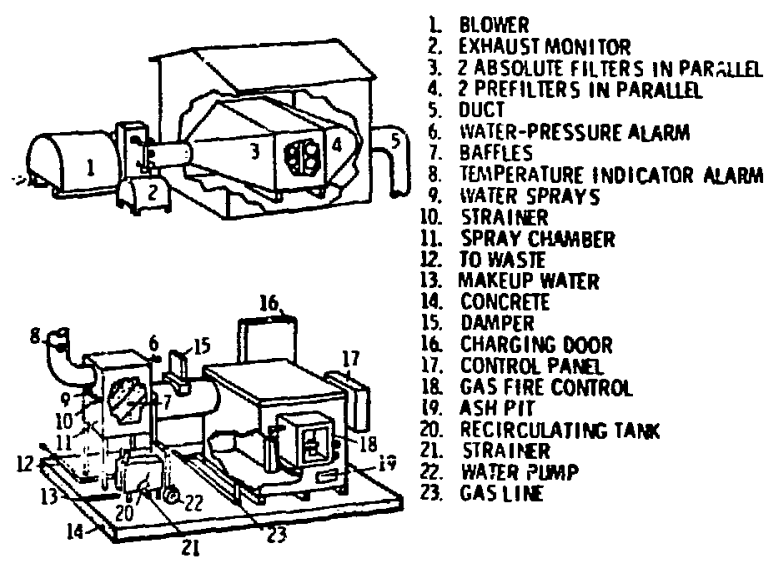

Fig. 33.

Incinerator at General Electric, San Jose, CA.
Ash Removal. The ash produced during burning dropped to a removable tray. When the incinerator was shut down and the urit had cooled, the ashes were sprayed with water and shoveled into a drum for ultimate disposal. In general, the ashes contained $<0.1 \mathrm{wt} \%$ uranium and $\sim 99 \%$ of the $\mathrm{UO}_{2}$ remained in the ash.

Performance. Between start-up on February 11. 1960 , and August 22, 1960, 6747 boxes of waste were burned. This incinerator ran for $\sim 2 \mathrm{yr}$.

The Equipment Department expanded and it was necessary to increase the incinerator throughput, or to build a larger incinerator or to dispose of wastes by some other method. It was decided that it would not be economical to build a larger unit, so incineration of contaminated wastes was discontinued at this General Electric facility.

Problems. No complete documentation of problems with this incinerator is available; however, it is reported that before construction of the final incinerator, an incinerator arrangement containing only one and later two chambers was tested. Tests showed both choices to be unsatisfactory because of incomplete combustion of the waste.

Rapid clogging of the filters occurred when plastics, rubber gloves, and tape were incinerated. These items evidently were not included when the incinerator was operated on a production basis. However, the filters still plugged frequently, due in part to condensation of water and tars. A mist eliminator was placed between the spray cooler and filter to reduce mist carryover but, since the gases would continue to cool after passing the mist eliminator, complete elimination of condensation problems would not be expected. No data were found regarding improvement after the installation of the mist eliminator.

\section{SOURCES}

R. C. Thorburn and R. J. Chandler, "An Incinerator for Uranium Contaminateil Wastes," Ind. Water Wastes, March-April 1961, 46-48.

R. Dennis and L. Silverman, "Radioactive Waste Incineratur Design and Operational Experience - A Review," in Seventh AEC Air Cleaning Conf., October 10-12, 1961, AEC report TID-7627 (March 1962), pp. 424-426.

A. Tschaeche, General Electric, personal communication. 
R. C. Thorburn and R. J. Chandler, "Incinerator Reduces Volume of U-Contaminated Paper," Nucleonics 19, 86-87 (May 1961).

13. Nuclear Materials and Equipment Corp. (NUMEC), Apollo, PA. In 1967 NUMEC began a program to design and construct a treatment facility capable of recovering plutonium from wastes that included plastics, leaded gloves, paper and other cellulosics, metaliics, graphitics, and refractories, all slightly contaminated with plutonium and other radionuclides genergied during the fabrication of ZPPR ternary-alloy fuel plates.

After reviewing the literature, visiting sites having incinerators for radioactive wastes, and consulting an architect-engineer. the decision was made to burn the combustible wastes in a batch-type, auxiliary gas-fired incinerator. Before construction of the production facility a prototype test furnace was built.

a. Prototype Incinerator. In 1969 a full-scale prototype incinerator. designed for a throughput of $\sim 9.08 \mathrm{~kg} / \mathrm{h}(20 \mathrm{lb} / \mathrm{h})$ was constructed to obtain test data on the incineration of waste containing a high percentage of chlorinated plastics, leaded rubber gloves, etc.

Incinerator Design. The prototype unit (Fig. 34) consisted of two 15.2-cm (6-in.)-thick refractory cones, three gas burmers, an air blower, a flue pipe, and a stack.

The wastes, contained in ice cream cartons, were fed through the feed door onto the hearth of thi main combustion chamber. The hearth was a solid refractory disk pivoted along its centerline so that the ashes could be dumped. A solid hearth was chosen to avoid the melting and dripping of plastics into the ash pit. In theory, the plastics were supposed to melt and then completely volatilize or sxidize while contained in the hearth "dish."

A burner nei: the hearth area helped to maintain proper operating temperatures in that area. Once the gases and entrained particulates and soot left the hearth area, further burning occurred in the area of the second and third burners, which were separated by baffles; in effect, giving the unit secondary and tertiary incineration chambers. Ash dropped from both chambers into the main collection area beneath the hearth and no additional ash hoppers were necessary.

Monitors, including thermocouples, and pressure indicators, were used tu determine conditions in the incinerator. Flue gases were withdrawn isokinetically and particulate grain loading and gas composition were determined.

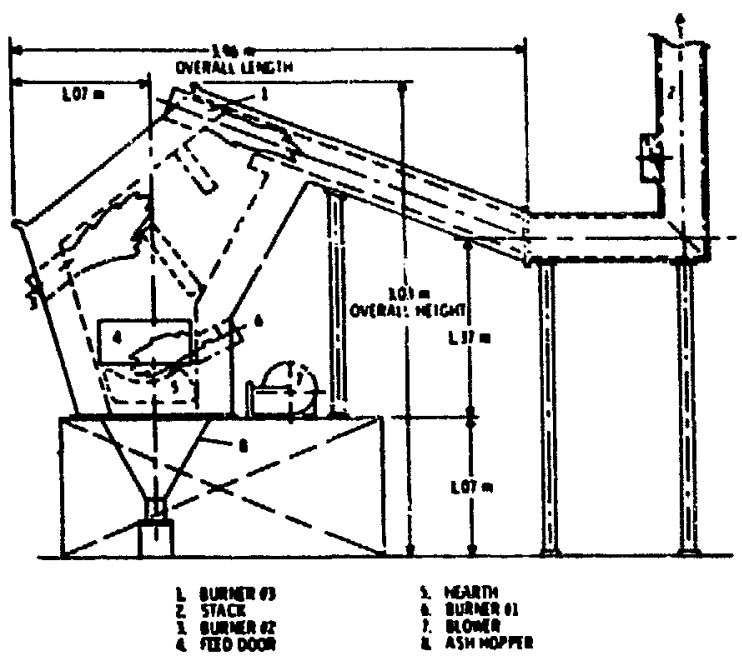

Fig. 34.

Prototype incinerator at NUMEC.

Performance. Twenty-two tests were run with the prototype incinerator. A heavy black smoke was observed whenever cartons of polyethylene sheeting wtre burned, and a light white smoke was observed during the burning of rubber gloves.

During test runs, the hearth was dumped to discharge the ash. No material accumulated on the hearth. No chlorine or chlorine oxides were detected in the flue gas. hence it was assumed that all the chlorine formed $\mathrm{HCl}$. The average weight loss for all the material burned was $84.5 \%$. No data are given as to how much of this ash was unburned carbon.

\section{b. Production Incinerator}

Incinerator Design. After testing of the prototype, a complete facility was dngigned. The loading system included a charging ooor and interlock chamber. The furnace was to be similar to that of the prototype, except that the upper chamber was eniarged slightly to provide more retention time. Approximately 24 cast refractory shapes inade up the refractory shell. These were going $t o$ be surrounded by insulating material and then a segmented external steel shell. The furnace was so designed that easy disassembly would be passible through a glove box. The hearth was desinned sos that one side at a time could be replaced.

A large glove box was to enclose the rurnace. carton feeder, and ash-removal unit. Glove entrifices would permit package feeder loading, ast $t_{1}-1$ an removal, and routine maintenance. 
(I)/-lias Cleanup. The off-gas cleanup train was designed for the following sequence: (') Aerodyne cyclone, (2) absolute filters, (3) wet scrubber (basic solution) with liquor cooling and blowdown cycle. (4) heater. (5) Tinal absolute filters. (6) damper. and $(7)$ induced-uraft fan.

Present Status. The NUMEC incinerator farility was never built. A final cost anaiysis showed that an incinerator could not be operated economically: on waste from NUMEC alone.

In 1971 Atlantic Richnield Co. sold NUMEC to Babcock and Wilcox. but ARCO retained access to the incinerator design.

The Aerodyne cyclone has undergone some testing at Hanford. where it was found to perform better than most cyclones although it is extramely noisy.

\section{SOURCES}

R. L. Bragk and F. D. Fisher, "Recovery of Plutonium irom 2PPR Linmeasurable Wastes. Progress Report. July 27. 1967 . January 27. 1968." Nuclear Materials and Equipment Corp. report NUMEC-1661-1.

H. A. Garber. "Recovery of Plutonium from ZPPR Unmeasurable Wastes. Progress Report. January $2 i$. 1968 - July 31. 1968," Nuclear Materiols and Equip. ment Corp. report NUMEC-1661-2.

H. J. Garber. "itecovery of PJutonium from ZPPR Linmeasurable Wastes. Propress Report. August 1. 1968 - January 31. 1969," Nuclear Materials and Equipment Corp. report NUMEC-1661-3.

F. D. Fisher and M. C. Gilchrist, "Recovery of Plutonium from ZPPR Unnieasurable Wastes. Progress Report. February 1. 1969 - Jufy 25. 1969," Nuclear Materials and Equipment Corp. report NUMEC-1661-4.

F. D. Fisher and M. C. Gilchrist. "Recovery of Plutonium from 7.PPR Unmeasurable Wastes. Progress Report, July 26. 1969 - January 29, 1970." Nuclear Materials and Equipment Cosp. report NUMEC-1661-5.

Ray Walton. Jr., AEC Div. of Waste Management and Transportation, to C. W. Christenson. LASL. written communication.

W. P. Ingalls. Allantic Richfield Hanford Co., personal communication.

\section{B. Present US Incinerators}

1. National Lead Co. of Ohio (NitCO). Fernald, OH. NLCO operates several incineratons to birn various types of low-isvel wastes contaminated with depleted to low.enrichment ( $<1059255$ U) uranium at their Feed Materials Production Center. The wastes include trash. graphite, and oil.

a. Trash Incinerator. The trosh incinerator operates at Ferneld $\sim 6 \mathrm{~h} / \mathrm{day} .3$ days/wk, 50 wk/yr. On the average, about $22680 \mathrm{~kg}(50000 \mathrm{lb})$ of slight ly contaminated paper, wood. rags, and similar combustibles and small quantities of oil-sludge resioue are incinerated in 1 month. Plastics are not included in the solid waste material fed to the incinerator but are deposited in anitary landfill.

Incinerator Design. The incinerator, shown in Fig. 35. is a multiple-chamber unit with a rated capacity of $998 \mathrm{~kg} / \mathrm{h}(2200 \mathrm{lb} / \mathrm{h})$.

The oil-sludge residues are slowly burned in shallow peisis inserted between the primary and secondary combustion areas of the incinerator.

()/f-Gases. There is no off-gas cleanup system. After the gases pass through the afterbumer, they exit dirently to the atmosphere through a stack lined with $7.62 \mathrm{~cm}$ of hydro-mix castable refractory.

Problems. No major problems have been reported since this unit was first placed in operation in 1954. However, to obtein cumplete combustion of the off-gases from the oil slurige. a temperature of at least $982.2^{\circ} \mathrm{C}$ is required. The gas burners for the afterburner are not capable of maintaining this high temperature. 80 it is important during the incineration of sisdges to feed a trash with a fairly high heating value into the main combustion chamber to achieve the requirect temperature in the afterburner.

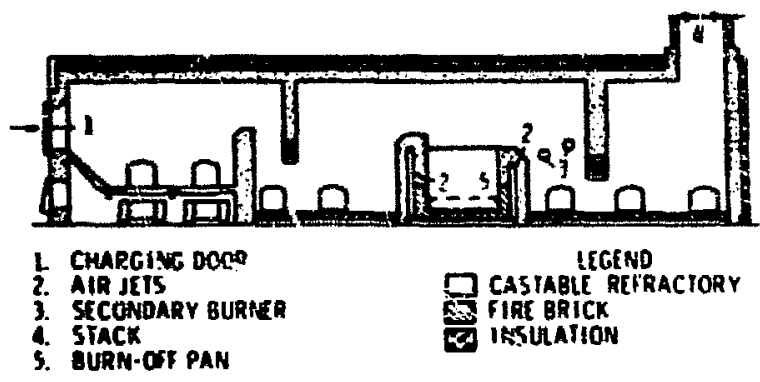

Fig. 35.

Incinerator at $N L C O$. 
Because plastics are excluded from the incinerator. and because the off-gases are kept at high temperature until they reach the atmosphere, corro. sion problems shouid be minimal.

b. Graphite Burner. Graphite crucibles and molds are used at NLCO, and in the course of their use sume uranium and daughter products enter the graphite.

Pretreatment of Wastes. When a crucible or mold is rejected, it is stored for a time to permit some decay in activity of such daughters of uranium as ${ }^{234} \mathrm{Th}$. Then the graphite is broken into $\sim 12-\mathrm{cm}$ diam pieces, drummed, and placed in storage until a sufficient amount of graphite has accumulated to warrant burning.

Incinerator Design. The incinerator (Fig. 36). deaigned ond gebricated ty iVi CO in 1962, is located outside. It normally operates $\sim 4 \mathrm{wk} / \mathrm{yr}$, with a graphite throughput of $68.1-79.4 \mathrm{~kg} / \mathrm{h}(150-175 \mathrm{lb} / \mathrm{h})$.

To place the burner in operation, a $7.62-\mathrm{cm}$ layer of sand is placed in the bottom of the combustion chamber: wood is placed on top of the sand. Next. a

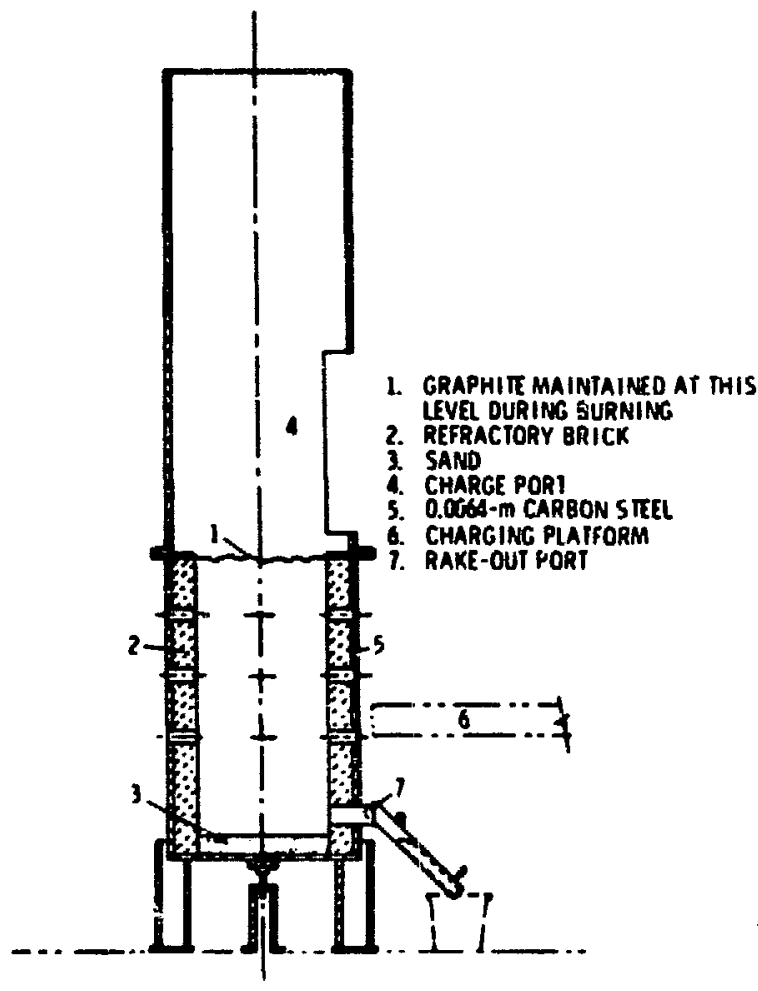

Fig. 36.

Incinerator for graphite, NLCO. wood fire is started. Oil-suaked coal is added until a $60.96-\mathrm{cm}$-thick bed of hot coals is available. Then a layer of graphite is placed on these hot coals and combustion air is fed to the bed through an air lance inserted through a bottom port. When the graphite is orange-red, more graphite is added and the air supply reduced. When combustion is proceeding at an acceptable rate, the lance is removed.

A $121.92-\mathrm{cm}$ (4-ft) bed of burning graphite is maintained through the addition of more graphite us necessary. Occasionally, the graphite must be poked or rabbled to prevent bridging.

Ash Removal. As the charge burns down. the ashes are reked through seve: ports into buckets. Once the ashes are cool, they are transferred to drums for storage, and later are transported to the uranium-recovery facility. The ash from the burner

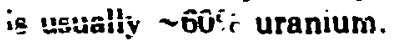

Off-(iases. There is no off-gas cleanup system. Particulate emission is minimized by trying to achieve good combustion of the graphite with a minimum of gas turbulence in the bed. Uranium in the stack effluent has ranged from $0.15 .8 .3 \mathrm{mg} / \mathrm{m}^{3}$. During a campajgn, the discharge of uranium to the atmosphere is estimated at $<0.227 \mathrm{~kg}(0.5 \mathrm{lb})$ for every $24 \mathrm{~h}$ of operation.

c. Oil Burner. During operation of the plant at Fernald, waste oils slightly contaminated with uranium are produced. Originally these oils were stored in druins on the site. but the drums would rust in the weather, acids in i..e wastes would cause internal corrosion, and water in the drums would sometimes freeze and cause the drums to crack. Even with replacement of bad drums, as the number of drums in storage increased, the risk of fire and of contamination of surface and ground waters also in. creased. The inventory finally reached $7.57 \times 10^{5}$ ， ( 200000 gal) of oil stured in $\sim 6000$ drums.

Clearly, some solution to the oil-storage problem was necessary. NLCO designed and fabricated a facility for the treatment and incineration of contaminated waste oil. This facility, placed in operation in 1957, now operates 4-6 wk/yr with a throughput of $\sim 45 \mathrm{~kg} / \mathrm{h}$.

Pretreatment of Wastes. A diagram of the trestment train and burner is shown in Fig. 37. The oil must first be treated to remove sludge and water.

Organic liquids are pumped from their storage drum into tank 1. Heavy sludges at the bottom are not included, but are scraped into another drum and. burned separately. After tank 1 has been filled. 


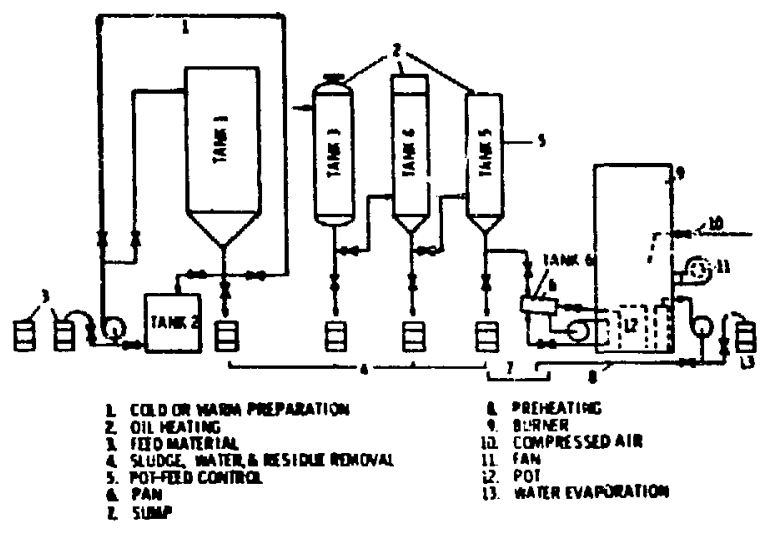

Fig. 37.

Treatment train and burner of NLCO's oilburning facility.

water and sludge are withdrawn from the tank bottom. Then sodium carhenate is added to further break any emulsions. After a 16-h settling period, the oil is drained into tank 2.

In tank 2, the temperature of the oil is raised to $100^{\circ} \mathrm{C}$; water und volatile organics evaporate, and sludge and water are withdrawn from the bottom. Next the oil moves to tank 3. In tank 3, the oil is heated to $112.8^{\circ} \mathrm{C}$, additiunal evaporation occurs, and sludge continues to settle. From tank 3 , the oil overflows to tank 4. From tank 4, it goes to tank 5 . In tanks 4 and 5 , the oil is heated to $137.3^{\circ} \mathrm{C}$. Tank 5 serves as a reservoir tank. In tanks $\mathbf{3 - 5}$, sludge and water are removed periudically from the bottom of each tank.

Incineration. The oil burner is started by 6 niting $7.56 /(2 \mathrm{gal})$ of kercsene in the burner pot. Tank 6 , the preneat tank, is filled from tank $\overline{5}$, and the feed-line from tank 6 to the burner pot is opened to allow gravity flow of oil to the burner pot. After burning has begun, oil in tank 6 is recirculatt.d through the furnace and pumped back to the tank through a separate loop. In this manner, the oil temperature is raised to $\sim 177^{\circ} \mathrm{C}$.

Addition of oil to tank 1 is continued to maintain feed for the burner. If no difficulties are encountered. the treatment and burning are continued until the entire waste-oil inventory has been processed. Properly controlled burning is attained by regulating two forced-air systems.

Some of the water drained from the treatment canks is evaporated in a separate pot located inside the brick enclosure. Water is first transferred to an elevated hold-tank outside the enclosure. It drains, by graviiy, through a $1.17-\mathrm{cm}(1 / 2-i n$.) line to a 20.3 - $\mathrm{cm}$-diam pot located near the oil burner pot. A valve on the line permits adjustment of the flow rate.

Ash Removal. Ash in the burnit pot is removed periodicaliy and drummed for later uranium recovery. Uranium content of the ash may reach $30 \%$.

Off-Gases. Average reported uraniuni levels sampled in the flue gas 1.53-3.05 m $(15.10 \mathrm{ft})$ downwind from the top of the stack are:

\begin{tabular}{l}
$\mathrm{mg} / \mathbf{m}^{3}$ \\
\hline 0.05 \\
0.2 \\
0.4 \\
0.8 \\
1.9
\end{tabular}

Properly controlled burning

Light smoke issuing from stack

Entrained ash visible above poit

Flame issuing from stack

Heavy smoke issuing irom stack

1.9

Problems. During periods of T.BP.kerosene burning under certain atmospheric conditions, volatiles and degradation products can oscur at ground level in cancentrations that can cause nesal and throes? irritations. Such irritations are believed to be mairly associated with $\mathrm{PO}_{4}$ and disappear quickly when burning :s stopped or when the individual leaves the immediate area.

\section{SOURCES}

4. F. Pennak. Senior Froject Engineer, Nat Lead Comp any of Ohio, written communication.

Environmental Protection Agency. State of Ohin, Emissions Inventory Form.

M. W. Boback, "Low Cost Incirerator Units for Disposal of Waste Graphite and Oils", National Lead Co. of Ohio report NLCO-1093 (October 1972).

K. E. Brandner, R. L. Bipes, and L. Williams, "Incineration of Waste Contaminated Oil." in Fighth AEC Air Cleaning Conf., Oak Ridge National Laboratory. October 22-25, 1963, AEC report TID7677, pp. 674-679.

2. United Nuclear Corp., Wood River Jurction. R1. United Nuclear Corp. has operated an in. sinerator for wastes slightly contaminated with enriched urunium at their Recovery Operations at Wood River Junction. The unit was installed in 
1967 , and has a design capacity of $45.5 \mathrm{~kg} / \mathrm{h}(100$ $(\mathrm{b} / \mathrm{h})$. but is not currently in operation.

Pretreatment of Wastes. Evidently some sorting was done to exclude noncombustibles; however. polyethylene sheet and bottles and polyvinyl olastics were included to some extent in the wastes.

Incinerator Design. The waste was loaded into the furnace. a singie-chamber unit, through a hinged-door arrangement. A gas burner maintained the proper operating temperature.

Off-Gas Cleanup. Initially the system was equipped only with a cyclone for off-gas cleanup. However. after several years of operation, the contamination levels in the waste increased, and it was necessary to install further equipment in the cleanup trair. A scrubber was installed in November 1973.

Problems. The problems at this facility have included (1) contamination, (2) plugging, particularly of vacuum lines, nozzles, and filters, and (3) scrubber-water disposal (accumulation of tars and carbon in the scrubber water required a water change after two to four drums had been processed).

The accumulation of tars and carbon in the scrubber indicates incomplete combustion. The incineration of plastics probably increased the concentration of tars and carbon in the furnace off-gases.

Present Status. In June 1974 the incineration facility was closed dowi. The staff of the Nuclear Regulatory Commission (NRC) indicated that closedown was necessary because of "problems in effluent control." Personnel at United Nuclear suspect thai the refractory stack liner may have becume contaminated.

At the present time, a tear-down and cleaning of the stack is under way; apparently, United Nuclear hopes to use this facility again. However, if the offgas cleanup train cannot handle the emissions from the incinerator, further control or permanent rlosedown of the facility may be necessary.

\section{SOURCES}

C. E. Bowers, Plant Manager, Inited Nuclear Corp. Fuel Recovery Operations, written communication.

R. Woolsey. NRC, personal communication.

3. Goodyear Atomic Corp., Piketon, OH. In the Uranium Operations Subdivision of Goodyear
Atomic Corp. at Piketon, wastes containing small quantities of radioactive materials in the form of UO, $F$, and uranium oxides are produced.

Most of the combustible waste consists of plastic shoe-covers, and varying amounts of paper, cardboard, and rags. To incinerate these wastes, a commercially available incinerator known as the Mark VI radicator was installed in May 1971. This incinerator is run on a batch hasis. About 2270 $\mathrm{kg} / \mathrm{month}(5000 \mathrm{lb} /$ month $)$ of contaminated material are incinerated.

Pretreatment and Loading of Wastes. The contaminated combustible wastes are placed in 242-1 (55-gal) drums for transport to the incinerator. The drums of trash are loaded into the primary chamber ihrough an end door. As the trash is loaded, an operator wearing a full face inask sorts the loose trash in the drums, rejecting any noncombustibles.

The incinerator is loaded with a set number of drums. The number of drums to be loaded at one time is determined by establishing through a survey of many drums the maximum possible amount of uranium in each drum and calculating the uranium content of the resulting ash. (The uraniurn content of the ash must not exceed a predetermined quantity.)

Incinerator Design. The incinerator is a doublechamber type composed of two cylinders mounted one above the other with a special, hightemperature, cast refractory lining. When the primary chamber has been loaded, the trash is ignited. As the material burns, the off-gases pass into a secondary chamber, maintained at $815.5^{\circ} \mathrm{C}$ by a propane burner. Any material not completely oxidized in the primary chamber is oxidized further in the secondary chamber.

Ash Remaval. The ashes produced in the primary chamber fall to the floor, and after the incinerator has cooled, the ashes are vacuumed into drums which are sent to the ash-leaching facility for uranium recovery.

Other Features. There is no off.gas cleanup system. The gases from the secondary combustion chamber exit into a ceramic-lined stack. Safeties close the system down whenever the temperature exceeds or drops below a preset level.

Problems. No major problems have been reported in the system. Initially, the unit was outside, but wind, snow, and rain marle safe loading difficult. 'Therefore, an unheated shed now' encloses the 
facility. It is necessary occasionally to decontaninate this area.

There have been no serious corrosion problems, probably because of the thick refractory linings of the facility and the fact that gas temperatures are always well above the dew point.

Despite the fact that the unit is run on a batch basis and undergoes thermal cycling, no replacement of the lining in either chamber has been necessary. A few repairs will be made to some cracks in the refractory.

\section{SOURCES}

Radicator bulletin-RP-12467, Midland-Ross Corp.

J. C. Crawford, Superintendent, Uranium Operations Subdivision, Goodyear Atomic Corp., written and personal communications.

\section{Union Carbide Corp., K-25 Plant, Oak Ridge, TN}

Low-Level Radioactive-Waste Incinerator. An Incinerator for very low-level radioactive wastes has been in operation at K-25 for $\sim 3 \mathrm{yr}$. It is used to incinerate floor sweepings that contain uranium, so that the uranium can be recovered from the ash.

This incinerator operates almost every weekday until, for purposes of criticality control, it must be cooled down and the ashes removed.

Incineration. Each morning the main primary combustion chamber is heated by a gas burner until a temperature of $\sim 927^{\circ} \mathrm{C}$ is reached. Then the burner is shut off and the floor sweepings are fed through a door into the primary chamber at regular intervals in order to maintain a temperature of 927$1093^{\circ} \mathrm{C}$ in the primary chamber. Underfire air is used in the first chamber.

After oxidation and volatilization in the primary chamber, the gases oxidize further in an afterburner, where a gas burner is operated at all times.

Off-Gases. There is no off-gas cleanup system. The gases go directly from the afterburner into a stack and then to the atmosphere. The stack has no damper.

Ash Removal. The hearth in the primary combustion chamber is also the floor of the chamber. When the ashes are about $3.81 \mathrm{~cm}$ deep on the hearth, they are raked and some further combustion occurs. Then the facility is allowed to cool until the ashes can be raked manually through a sieve into a drum. They are then sent for uranium recovery.

Problems. The incinerator facility is not contained. The operator must wear a respirator while raking the ash and doing any other operations requiring close contact with the incinerator.

In the early days of the facility, some sintering of the ash occurred, as well as incomplete combustion (hence incomplete carbon removal from the ashes). This problem was overcome by having the operator rake the ashes toward the end of the burning period.

The temprature indicators and door gaskets have had to be replaced. So far, no major repairs have been necessary in the furnace lining despite the cyclic nature of the operation, but the lining may be about ready to break down in a few places.

Because there is no off-gas cleanup, pressure excursions usualiy result only in an increase in the flow of gases out of the stack. Moreover, since no PVC or rubber is incinerated, and since the gases are not cocled before exhausting to the atmosphere, corrosion problems are minimal.

\section{SOURCE}

J. Robinson, supervisor for the incinerator, Union Carbide K-25 Plant, persnnal communication.

\section{Union Carbide Corp., Paducah, KY}

Low-Level Radioactive-Waste Incinerator. In the past, an incinerator with a scrubber has been operated at Paducah to incinerate low-level wastes containing depleted to slightly enriched uranium. The unit has not been used for some time because of corrosion problems and the need to improve scrubber efficiency. Engineering studies are in progress, and the facility may be back in service by FY 76. Pendirs modification to the unit, uraniumcontaminated combustibles are being stored. Interim storage is not a problem at present because the generation rate of such material is low.

\section{SOURCE}

R. W. Levin, Superintendent, Laboratory Division. Union Carbide-Paducah, written communication. 
6. Union Carbide Corp., Y-12 Plant, Oak Ridge, TN. For $>15$ yr an incinerator and four destructive distillation units have been operated for AEC/ERDA by Union Carbide's Nuclear Division as part of the process to recover nonirradiated, highly enriched uranium $(93 \%$ 235 U) from low-level radioactive wastes at $\mathrm{Y}-12$. All the facilities are currently in regular use, and the distillation units are used $\sim 1 \mathrm{wk} /$ month for those instances where material must be kept separate for assay purposes.

Pretreatment of Wastes. The wastes destined for the incinerator and the distillation units are presorted before they are processed. All noncombustibles, plastics, and rubber are removed. The plastics and rubber are sent to the leaching facility for uranium recovery. The incinerated wastes consist mostly of paper, rags, and wood.

Distillation Units. The destructive distillation units have a maximum throughput capacity of 2 $\mathrm{kg} / \mathrm{h}$. The ovens are heated electrically to $\sim 260^{\circ} \mathrm{C}$, and during the distillation cycle, they operate under a nitrogen atmosphere. When distillation is complete, the residue is burned to ash under an oxygen atmosphere.

Off-Gas Cleanup for Ovens. The off-gases from the oven pass through a water seal where some of the oils and tars condense. The water quickiy becomes quite oily. Some $\mathrm{HCl}$ is produced from plastics in the feed. About $500 \mathrm{ppm} \mathrm{Cl}^{-}$have been detected in the seal water. The water usually does not contain uranium and is discharged directly to the burial pit. The gases pass from the viater seal to a condenser before discharge to the atmosphere. The gaseous discharge from the distillation facility is monitored regularly. The amount of $235 \mathrm{U}$ is considerably less than the maximum permissible limit.

Problems with Distillation Units. Tars and oils not removed by the water seal condense on the walls of the duct and corrode them. These hydrocarbon deposits must be cleaned routinely to eliminate the hazard from fire.

Maintenance of the distillation units is difficult, hence they are used only when batch $2.35 \mathrm{U}$ accountability is important.

Incinerator Loading. The prepackaged feed is introduced into the incinerator through a door-ramdoor arrangement.

Incinerator Design. The Y-12 inci' lerator is $\sim 20$ yr old, and its throughput capacity is $\sim 20 \mathrm{~kg} / \mathrm{h}$. The incinerator consists of a single, cylindrical chamber lined with refractory. A rabble arm sweeps the area above the solid hearth. Wastes can be introduced into the incinerator at every $180^{\circ}$ sweep of the rabble arm. Two gas-fired burners are used to maintain operating temperatures in the chamber.

Off-Gas Cleanup for Incinerator. The gases leave the incinerator at $\sim 871^{\circ} \mathrm{C}$ and pass through (1) a water-cooled heat exchanger, where they are cooled to $260^{\circ} \mathrm{C}$ before passing into (2) a cycione and then into (3) a multitube dust collector. Finally, the gases are (4) diluted by addition of air from the canopy-hood area and pass through (5) a baghouse. The baghouse removes small particulates before the gases are discharged to the atmosphere. The concentration of $235 \mathrm{U}$ in the stack gas is below the maximum permissible limit.

Ash Removal from the Incinerator. The ashes are collected in suitable ash hoppers and are removed, continuously screened, pulverized in a ball mill, and then sent for $235 \mathrm{U}$ recovery.

Problems in Incinerator Operation. The major operational problem is one of containment. It is difficult to maintain a $100 \%$ airtight system; there is leakage around the loading and ash-removal ports and, because of the variability in the feed, occasional increases in furnace pressure can cause leakage into the operating area. The plant's maximum permissible level of $70 \mathrm{dpm} / \mathrm{m}^{3}$ is seldom exceeded, and the level for respiratory proiection $\left(200 \mathrm{dpm} / \mathrm{m}^{3}\right)$ is exceeded only on rare occasions. As a precautionary measure, coveralls and respirators are required for personnel working in this area.

One fire has been reported in the bag filters in 20 yr of operation. The two dust collectors and the ducts ahead of the bag filters probably serve also as delay chambers and permit the oxidation and cooling of any sparks from the combustion chamber.

Corrositon is not a major problem because little PVC or rubber is incinerated and because temperatures in the off-gases are fairly high.

Replacement of some of the refractory is required every $2-3 \mathrm{yr}$, and complete replacement is required every 6-8 yr. When this is done, the salvaged refractory is scraped and washed to recover any surface contamination. If the refrastory is still too contaminated to be discarded, it is pulverized and leached before being put in the burial ground.

\section{SOURCES}

L. R. Phillips, Information Control Officer. Union Carbide Y-12 Plant, writien communications. 
I. Ruthven, Union Carbide Y-12 Plant, personal communication.

D. Smith, Union Carbide Y-12 Plant, fersonal communication.

R. S. Foster, "Incineration of Plutonium Contaminated Waste Materials, A Preliminary Study for Replacement of the Existing Rocky Flats Incinerator," Dow Rocky Flats report RFP-735 (May 1966).

7. Gulf General Atomics (GGA), Nuclear Materials Div., San Diego, CA. GGA in San Diego inciners'es combustible wastes contaminated with small quantities of enriched uranium ( $\sim 93 \% 235 \mathrm{U})$. The entire incinerator facility is located outside.

Pretreatment of Wastes. Wastes are first sorted to remove noncombustibles, plastics, and rubber gloves. The remaining waste is placed loose in 242.1 barrels. Fill barrels are sent to the assay area where they are gamma-counted in a barrel counter to determine the $225 \mathrm{U}$ content of each barrel. The barrels are then delivered to the incineration site.

Loading. The incinerator is usually operated on a weekly cycle. On Monday morning a barrel is unloaded and the incinerator is filled. The trash is ignited and allowed to burn. When the initial load has about burned out, more combustible trash is fed in. (Any noncombustibles, rubber gloves, or large quantities of wet material are piaced in a nearby scrap barrel.) This procedure continues each 8-h day (usually through Thursday) until it is estimated that the charging limit for $235 \mathrm{U}$ has been reached. Then the system is closed down and allowed to cool. Usually, $\sim 40.50$ barrels can be processed hefore the $235 \mathrm{U}$ limit is reached.

To determine the maximum permissibie charge of $225 \mathrm{U}$ to the incinerator, several factors are corisidered. The operating license for the incinerator allows the accumulation of $1500 \mathrm{~g}$ of $235 \mathrm{U}$ in the system: 500 each in the combustion chamber, baghouse, and soot hopper. Before operation begins. $225 \mathrm{U}$ hold-up levels (determined by gamma scan) are asaignnd to various parts of the incinerator. To determine the maximum allowable combustionchamber charge of $235 \mathrm{U}$ during a run. the highest hold-up for each of the three sections is determined and the amount of $235 \mathrm{U}$ to be charged is determined by subliracting this hold-up from the 500 -g allowable 245 content. Thus, if the baghouse has a hold-up of. say, 102 of $235 \mathrm{U}$. the $235 \mathrm{U}$ input to the incinerator is limited to $398 \mathrm{~g}$ on the assumption that all of the special nuclear materials (SNM) charged to the combustion chamber could be collected in the baghouse and would not then exceed the 500-g limit.

The operator wears a respirator and protective clothing during loading and ash removal.

Incinerator Design. The incinerator is a multiple-chamber unit with (1) a primary propanefueled burning chamber separated from the asl pit by the grate, (2) a secondary burn chamber, also propane-fueled, and (3) a mixing chamber where additional air is bled in.

The chambers are brick-lined. The primary combustion chamber operates at $371.1204^{\circ} \mathrm{C}$; the secondary is maintained at $1204^{\circ} \mathrm{C}$.

Feeding times and operation of the burner are determined by visual inspection of combustion conditions in the primary chamber. The capacity of the furnace is sufficiently large to allow 8 -10 barrels to be charged each 8-h day.

Off-Gas Cleanup. Gases go from the incinerator to a $37.3-\mathrm{m}$-long duct. Four wire-mesh screens in the duct are placed perpendicular to the gas flow at the follow:ng distances from the incinerator:

\begin{tabular}{|c|c|c|}
\hline Mesh & Wire Size & Distance from Incinerator \\
\hline 2 & $0.266 \mathrm{~cm}(0.105$ in. $)$ & $3.81 \mathrm{~m}(12.5 \mathrm{ft})$ \\
\hline 2 & $0.266 \mathrm{~cm}(0.105$ in.) & $13.56 \mathrm{~m}(44.5 \mathrm{ft})$ \\
\hline 2 & $0.266 \mathrm{~cm}(0.105$ in.) & $16.61 \mathrm{~m}(54.5 \mathrm{ft})$ \\
\hline 4 & $0.160 \mathrm{~cm}(0.063 \mathrm{in.})$ & $29.41 \mathrm{~m}(96.5 \mathrm{ft})$ \\
\hline
\end{tabular}

These screens serve to catch and break up any large pieces of unburned. but perhaps still glowing, materiai.

After passing down the duct, the gases enter a baghouse which is contained in a shell $9.15 \mathrm{~m}$ (30 ft) high. There are 32 glass-cloth bags $\sim 5.78 \mathrm{~m}$ high and $0.3 \mathrm{~m}$ in diameter. The bags are shaken at regular intervals and the soot discharged into a soot hopper below the bags. From the baghouse the gases pass through a filter unit. Finally, the gases discharge through an induced-draft fan into the stack. Emission of $2 \times 5 \mathrm{U}$ into the ambient air is monitored.

Ash Removal. After the build-up limit for $235 \mathrm{U}$ has been reached. the system is shut down and allowed to cool. The cool ashes from the combustion chanber are shoveled manually into a barrel. The soot hopper below the baghouse is also emptied. Abuut 1 barrel of ash is obtained from every 10 barrels of incinerated waste.

The residues from the burn are then sent to the assay facility for gamma-cuunting. Any residual 
2:35 $\mathrm{U}$ can then be determined by a material balance. In acidition to this system of determining residual $235 \mathrm{U}$, the various units of the facility are also gamma-scanned to de'ermine $235 \mathrm{U}$ hold-up. Ashes that contain sufficient $=75 \mathrm{U}$ are sent to recovery.

Problems. The incinerator at GGA began operation $\sim 12$ yr ago. At that time, the long duct between the incinerator and baghouse was not installed and several problems were experienced. Because there was no cooling duct. gases entered the baghouse at $\sim 260-315^{\circ} \mathrm{C}$, the maximum temperature at which a baghouse can operate. Moreover, some pieces of entrained soot would continue to glow and, when deposited on a bag, would char a small area of the bag and weaken it so that it would tear when shaken. This, in turn, would place a heavy load on the absolute filter which would soon clog. Operation was so unsatisfactory that the facility was closed down.

Eventually, an extensive amount of combustible waste was accumulated in storage, and it was decided to place the incinerator in operation again. Modifications were made, however. The long duct. which permits further oxidation of the particulate and which permits the gases to cool, and the screens, which are barriers to large pieces of particulate which may still be glowing, were installed. The incineration facility has operated for $\sim 1 \mathrm{yr}$ with these modifications, and during that time the lags and absolute filter unit have never been changed.

Some migration of $235 \mathrm{U}$ into the walls of the incinerator probably does occur, but the operators do not feei that it is a major problem at present.

Incineration of plastics was tried at one time; however, the plastics melted on the grate without burning, and not only gummed the grate but ran into the ash-receiving area of the incinerator and slowly smoldered there. Consequently, plastics are now excluded from the wastes fed to the incinerator.

Incineration of rubber gloves was also tried. They tended to clump together and burn slowly, and occasionally a glowing piece would become entrained in the off-gases. It would then deposit on a bag, causing material failure of the bag. Rubber gloves are now exr:luded also.

Improved gamma-counting techniques have led to improved material balances throughout the system, thereby making it easier to operate the incinerator.

\section{SOURCES}

F. Carpenter, GGA, personal communication.

R. Vanek, GGA, written and personal communications.
G. Amy, GGA, personal communication.

8. General Electric Nuclear Fuel Plant, Wilmington, NC. General Electric operates a large reactor fuel fabrication plant in Wilmington, NC. Each year this facility produces between (141.5-283) $\times 10+/\left(50000-100000 \mathrm{ft}^{3}\right)$ of combustible waste contaminated with uranium $(\sim 2.5 \mathrm{wt} \%$ 235 $\mathrm{U})$. An incinerator was installed in $\mathbf{1 9 7 0}$ to burn the wastes and to recover some of the uranium.

Pretreatment of Wastes. The wastes are presorted at the generating site before being sent to the incinerator facility. There they are sorted again and noncombustible items are removed. The waste accepted for incineration includes PVC and rubber.

Loading. The wastes are placed in 28.3./ plastic bags and gamma-scanned to determine their $235 \mathrm{U}$ content. They are then put on a belt conveyor which feeds into a 141.5-f (5- $\left.\mathrm{ft}^{3}\right)$ hammer-mill-type shredder. The shredded waste is blown, by a materials-handling fan, through a $15.24-\mathrm{cm}$ (6-in.)diam duct at $\sim 0.708 \mathrm{~m}^{3} / \mathrm{s}$ into the incinerator. The pretreatment train, incinerator, and off-gas cleanup system are shown in Fig. 38. The incinerator is fed until $1500 \mathrm{~g}$ of $235 \mathrm{U}$ may be in the system. Then the unit is shut down and cleaned.

Incinerator Design. The incinerator is a Vortex I Vorcinerator. The shredded material is fed tangentially into the $1.37-\mathrm{m} \times 2.44-\mathrm{m}(4.5-\mathrm{ft} \times 8-\mathrm{ft}$ ) cylindrical combustion chamber. The incinerator has a rated capacity of $1362 \mathrm{~kg} / \mathrm{h}(3000 \mathrm{lb} / \mathrm{h})$; however, waste is usually fed at the rate of about $227 \mathrm{~kg} / \mathrm{h}(500$ $\mathrm{lb} / \mathrm{h}$ ). The temperature of the gases in the chamber is $\sim 815^{\circ}-982^{\circ} \mathrm{C}$. A natural-gas-fired burner is used upon start-up to achieve the proper operating temperature.

The furnace is lined with refractory bricke and has a metal shell. During operation, the furnace vacuum usually runs $-124 \mathrm{~Pa}$ to $-498 \mathrm{~Pa}(-0.5$ to -2 in. water gauge).

Off-Gas Cleanup. The gases and entrained particulates pass from the incinerator into a wet-spraytype scrubber, where they are cooled, the larger pieces of particulate removed, and some of the acid gases absorbed. The gases exit the scrubber at $\sim 93.3^{\circ} \mathrm{C}$.

From the scrubber, the gases pass through an impingement-type mist-eliminator for removal of any entrained droplete, and then pase through a reheat coil. Finally, they pass through prefilters and 

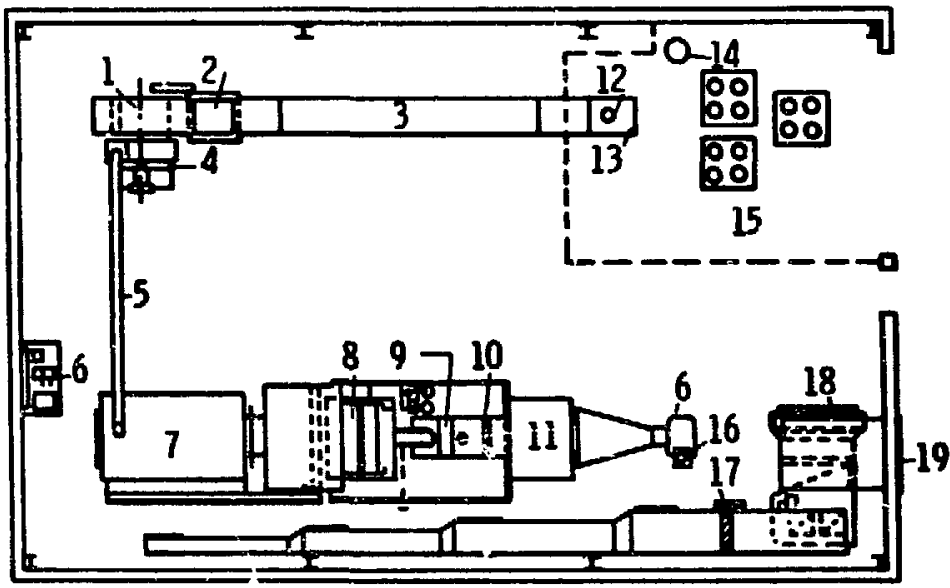

1. AUGER FEED

2. SHREDDER

3. CONVEYOR

4. MATERIAL-HANDLING FAN

5. MATERIAL-HANDLING DUCT

6. EXHAUST FAN

7. INCINERATOR
8. SCRUBBER

9. DEMISTER

10. REHEAT COIL

11. FILTER HOUSING

12. EXHAUST

13. DUMP HOOD

14. SCANNER

\section{CONTROLLED AREA \\ IWASTE STORAGE)}

16. FAN DISCHARGE STACK

17. ELECTRIC DUCT HEATER

18. RETURN-AIR GRILLE

19. STORM LOUVER

Fig. 38.

Incineration system at General Electric, Wilmington, $N C$.

a HEPA filter bank before going into the discharge stack via an induced-draft fan.

The liquid from the sprays in the scrubber falls to the bottom of the scrubber vessel. Then it is pumped through a GAF-type filter for removal of insoluble compounds. There are two GAF filters in parallel; one is used while the other is being changed or is on standby. A bleed stream from the liquid flow is routed to the radiation-waste facility. Make-up water is added to replace water lost from the system. No neutralization of the liquid occurs. The $\mathrm{pH}$ of the liquid circulating through the system is not deter. nined.

Ash Removal. When $1500 \mathrm{~g}$ of $235 \mathrm{U}$ are estimated to be in the system, the facility is shut down and allowed to cool; the incinerator is opened, and the ashes are shoveled out.

Problems. The incinerator is currently $\mathrm{o}_{\mathrm{i}}$ : line $\sim 50 \%$ of the time. During downtime a great deal of effort is put into maintenance work.

There are three major problem areas in tho incinerator: (1) loading system, (2) off-gas clerinup train, and (3) high gas usage.

One problem with the loading system has been that, despite the double-sorting, noncombustibles still get into the shredder. Pieces of metal, mop heads, coveralls, etc., clog and damage the shredder.

Another problem has been containment. Because the feed is blown through a line between shredder and incinerator, vibrations in the system cause stress on the seals and connections in the line. When these become loose, material can enter the operating room. (During operation, operators must wear respirators and protective clothing.) The shutoff damper was initially placed in the wrong spot and material remained in the pipe, but that problem is being corrected. Work is now in progress to improve other aspects of the feed system.

Despite the fact that the material .. shredded, variations in combustion conditions in the incinerator still exist because of the lack of homogeneity in the wastes. Rapid rise in furnace temperature can cause the system to shut down.

Problems have also been experienced in the off-gas train. A major reason is that incineration of PVC and other compounds containing $\mathrm{Cl}$ and $\mathrm{F}$, etc., produce: 3 $\mathrm{HCl}, \mathrm{HF}$, and other acid-producing compounds in the off-gases. These compounds are then absorbed by the scrubber water and the water becomes acidic. Entrained droplets from the scrubber may contain $\mathrm{HCl}, \mathrm{HF}, \mathrm{HNO}_{3}$, etc. In addition, acid gases not absorbed in the scrubber can condense later in the 
train on equipment at points below the dew point. Corrosion of the scrubber, mist eliminator, filter housing, and stack has occurred. The original stainless-steel scrubber was replaced by a titanium scrubber. The stainless-steel mist eliminator was first replaced by one of Teflon, and later by one of titanium which appears to be holding up well. Corrosion continues to be a problem for the HEPA housing and 'stack. At present, there is no neutralization of the scrubber water.

Another problem has been clogged spray nozzles. When they clog, not only are the particulates and acid gases not removed, but the gases are not cooled. This, of course, causes problems downstream in the train.

The GAF filters in the liquid-cycling system also clog, causing problems similar to those caused by the clogged spray nozzles.

The filters also have clogged. The scrubber does not remove enough of the particulate, and a major burden is placed on the dry filters, which must therefore be changed at regular intervals.

Temperature levels in the incinerator room have been excessively high, but were lowered somewhat by an air-conditioning system. Consideration is now being given to placing an insulating wall around the incinerator.

The incinerator requires a large amount of auxiliary fuel gas to maintain operating temperatures $\left[\sim 0.0156 \mathrm{~m}^{3} / \mathrm{s} / \mathrm{kg}(15 \mathrm{scfm} / \mathrm{lb})\right]$. The incinerator itself is holding up well. Data are being taken on the carbon content of the ashes.

Performance. In the first 9 months of operation, $\sim 594 \times 10^{3} /\left(21000 \mathrm{ft}^{3}\right)$ of contaminated waste were burned. The volume of this waste was reduced to $\sim 28300 \mathrm{i}\left(1000 \mathrm{ft}^{3}\right)$. At present, three shifts/day, five dəys/wk are used to maintain and operate the facility.

\section{SOURCES}

G. Sakash and P. M. Dawson, "Incineration of Low Uranium Content Wastes," Trans. Am. Nucl. Soc. 17, 330-331 (1973).

On-site visit by $\mathrm{C}$. W. Christenson and $\mathrm{H}$. Jones, LASL.

J. Mohrbacher, General Electric, written and personal communications.

9. Westinghouse Nuclear Fuel Division, Columbia, SC. The laboratories and fuel fabrication facilities of the Nuclear Fuel Division of Westinghouse produce combustible wastes contaminated with slightly enriched uranium ( $\leq 4 \mathrm{wt}$ \% $235 \mathrm{U}$ ). The wastes consist usually of paper, plastic shoe-covers, gloves, mops, plastic bags, and fiberboard containers. As much as $50 \%$ plastic may he present in the waste.

Pretreatment of Wastes. Wastes are delivered to the incinerator area in drums or baled in fiberboard boxes. The containers are scanned in the gammacounting facility and are marked to indicate the $235 \mathrm{U}$ content of each. The containers are then stored in critically safe configurations near the incineration area.

Loading. Before incinerator start-up, large pieces of material to be burned are placed on the floor of the primary combustion chamber. The controls and meters are checked, fans and pumps are turned on, and the incinerator is placed in operation.

The baled boxes are transferred to the ram chamber by a monorail hoist, and are charged through a double-doored ram feeder. Polyethylene bags of wet filters, etc., can be placed on top of the baled waste. The ram is actuated and the waste is fed to the primary combustion chamber every time the temperature in the combustion chamber drops below a preset level, until a maximum possible $950 \mathrm{~g}$ of $235 \mathrm{U}$ is estimated to be in the incinerator system. Then the charging is stopped and shutdown procedures are initiated.

Incinerator Design. The primary combustion chamber of this multichamber incinerator (Fig. 39) is a refractory lined cylinder contained in a steel box and is equipped with a natural-gas fired burner. Excess air enters through 24 air holes in the lower sides of the chamber. There is no grate, so the ashes lie on the bottom of the chamber. The afterburner is located in the exit exhaust pipe. Additional air is blown into this area, and two burners maintain operating temperatures.

The breech is equipped with a barometric damper through which dilution air can pass. This arrangement allows for some variation of pressure in the incinerator system without affecting the scrubber system or, for example, causing blowout of gas from the ram area. Only a moderately small amount of dilution air comes through the damper.

Off-Gas Cleanup. From the breech, the gases and entrained particulates pass through a stainlesssteel, double-walled, liquid-cooled, wet scrubber (Fig. 39). A set of liquid-spray nozzles in this scrubber sprays the gases as they pass through. 


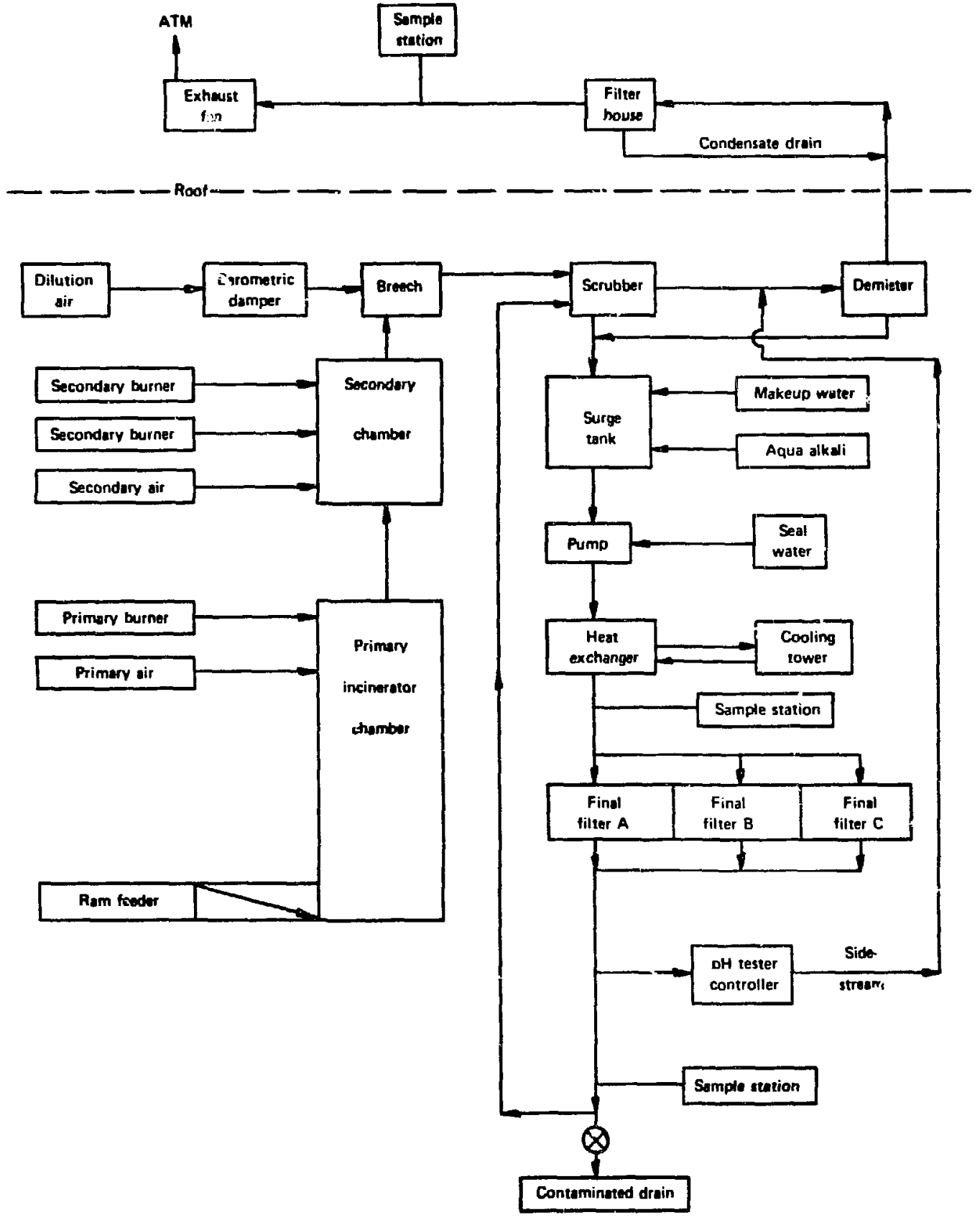

Fig. 39.

Flow diagram for incinerator at Westinghouse, Columbia, SC.

Only one set of water sprays is run at a time and therefore a spare set is available. The gases are cooled, and some of the large particulate matter and acid gases are removed. Then the wet gases pass through a centrifugal demister for removal of larger, en. trained liquid droplets.

After the off-gases pass through the demister, they pass through prefilters, through HEPA filters for 
further particulate removal, and are finally discharged via the induced-draft (roof) fan into the atmcsphere.

An isokinetic sampler is located halfway between the HEPA filter house and the stack-exhaust fan. Sampling ports are located immediately before and after the filter house.

The liquid from the demister and scrubber passes into a surge tank (Fig. 39). A $50 \%$ solution of caustic is added to maintain a pH of 7 to 10 in the tank. During the hot part of the burn cycle, more water is evaporated than is added by the pump seal water, so additional city water is autinai.cally added to the reservoir. During the cool-down portion of the cycle, evaporation is considerably less, so that the excess input (via the seal water) is automatically discharged periodically into the plant's contaminated waste system. Only filtered water is discharged.

From the surge tank, the liquid is pumped through a water-cooled heat exchanger, filters for removal of insoluble particulates, and finally back to the scrubber. This sequence is shown in Fig. 39. Each of the three liquid filter sets consists of six $76.2-\mathrm{cm}$ ( 30 in.) cartridges in parallel. The filter sets are sequentially switched onstream to minimize changes. When these filters are changed, the housings are drained from the clean side of the cartridge filters.

Ash Removal. Once the incinergtor is cool, the ashes are removed by a vacuum cleaner which discharges through HEPA filters. During ash removal, the incinerator facility's exhaust (induced-draft) fan is operated so that there is a positive air flow into the incinerator. The operator always wears gloves and protective clothing while vacuuming.

When the major portion of the ashes has been removed, the operator dons a fresh-air hood and, using a hoe or shovel, removes all noncombustibles. Then any remaining ash is vacuumed while the operator is inside the main combustion chamber. After the main chamber is clean, the two air headers are also vacuumed. Most of the air holes can be "rodded" clean.

When the cloth filter bag in the vacuum cleaner becomes full, it is changed and the ashes are placed in a pail. The lid is sealed and the pail transferred for counting. If sufficient $235 \mathrm{U}$ is contained in the pail, it is sent to the uranium-recovery facility. Noncombustibles are placed in drums. Prefilters and liquid filters are reburned. The only requirement on incinerator cleanup is that the entire system must never contain $>950 \mathrm{~g} 235 \mathrm{U}$, and this figure must include allowances for the uncertainty of measurement. If the total amount of MUF (material unaccounted for) does not permit a good-sized charge for the next burn, then incinerator operation becomes uneconomical. A thorough cleanout of sludge traps, chambers, and barometric damper is necessary to establish a new low MUF figure.

Safety and Controls. Monitors for temperature, pressure drop, flow rate, visual sight pariels, etc., contribute to the safe operation of this facility. Interlocks prevent charging under adverse conditions. An auxiliary power system permits orderly shutdown. An emergency ventilation system exists to discharge room air should the incinerator system vent to the room.

Problems. This facility first incinerated combustible materials containing no radioactive material. Improvements were made during this period of cold operation, and the facility began active operation in the summer of 1974 . Since then it has been out of operation for more time than it has been in operation.

One problem has been with the filters used in the scrubber-liquid system. In the beginning, wiper-type filters were used, but proved unsatisfactory and were replaced with CUNO-type filters. However, these too have been subject to plugging. Usually, replacement of two of the three filter sets is necessary during each shutdown.

Adequate particulate removal does not occur in the scrubber, and the pressure drop across the prefilters and HEPA filters increases rapidly. The Type I panel prefilters have been replaced with Type II extended-surface filters, but because of space limitations, these could not be very deep. Extendedsurface prefilters are changed routinely on every burn. The HEPA's are changed only when the pressure drop acrosis them does not permit sufficient gas flow. More complete initial combustion in the incinerator might reduce particulate- and tar-loading in the off-gases, which in turn would reduce plugging. A more efficient scrubber system would reduce the loed on the prefilters and HEPA's.

Consideration is currently being given to the use of water mist or steam sprays into the main combustion chamber to reduce temperature and pressure cycling.

When PVC is charged into the incinerator, it can melt before burning. The melted plastic then runs into the inlet air holes and plugs them so that they must be drilled out during downtime.

No serious corrosion has been observed in the stainless-steel scrubber system, probably because of careful $\mathrm{pH}$ control of the liquid before it goes into the scrubber.

Sometimes, during the periodic "new MUF" cleanouts, about a millimeter of original refractory 
material has to be removed from places where so litthe heat was applied during the burn that the plastic and carbon did not oxidize fully, resulting in $235 \mathrm{U}$ entrapment on the refractory surface. To reduce the problem, an attempt will be made to reorient the main burner toward this cool area at the bottom rear of the main chamber.

The difficulty of making an accurate determination of the residual contamination is the single nost important limitation on the weekly feed rate of contaminated wastes. Westinghouse personnel feel that all other performance pioblems can be solved.

\section{SOURCES}

On-site visit by L. Borduin, LASL.

Docket 70-1151, August 28, 1974 (AEC Directorate of Licensing, Washington, DC), pp. 176-195.

W. Goodwin, Westinghouse Nuclear Fuel Division, personal communication.

Description updated by G. Phifer, Westinghouse Nuclear Fuel Division, June 12, 1975.

10. Nuclear Fuel Services, Inc., Erwin, TN. The Erwin facility of Nuclear Fuel Services produces large amounts of combustible waste, some of which are contaminated with uranium of low enrichment and some with highly enriched uranium. An in. cinerator and calciners are operated at the facility. The incinerator burns wastes containing $<1 \mathrm{wt} \%$ of highly enriched uranium; the wastes include filters, sponges, gloves, and paper.

Loading. The drums of waste are gammascanned. Only drums containing less than a given amount of enriched uranium are opened and their contents burned in the incinerator.

Incinerator Design. The incinerator for waste containing highly enriched uranium is a Combustall, manufactured by Air Preheater. It is sized for $\sim 272$. $\mathrm{kg} / \mathrm{h}(600-\mathrm{lb})$ throughput. The primary combustion chamber is lined with refractory. An auxiliary burner is used to ochieve proper opersting temperatures. Combustion is controlled by metering preheated air into the gas-fired combustion chamber. As the gases leave the primary combustion chamber, additional air is added and further com. bustion takes place in the afterburner.
Off-Gas Cleanup. The gases from the afterburner exit to the off-gas cleanup system which also receives the gases from the calciner. The gases are cooled and large particulates are removed in the prescrubber. The gases next pass through a venturi scrubbrr for removal of the smaller particulates. Finally, the gases pass through a disengaging tank for removal of entrained mists, and exit through the exhaust blower.

The liquor from the scrubbers and disengaging tank is pumped through a bag filter for removal of insoluble particulates and then cooled in a heat exchanger, make-up water is added, and the liquor is recirculated to the prescrubber spray nozzles. The filters are changed daily and placed in containers of safe geometry. The scrubber solution is changed if a concentration of $2 \mathrm{~g} / \ell^{235} \mathrm{U}$ is exceeded. The solution is then processed through the scrap-recovery facility. The scrubber tanks are sampled monthly for buildup of $235 \mathrm{U}$ solids. Should there be excessive buildup, the tanks are cleaned.

Ash Removal. The combustible wastes are fed to the incinerator until it appears that one safe wet mass of $235 \mathrm{U}(350 \mathrm{~g}$ ) has been introduced into the system. Then the incinerator is allowed to cool before the ashes are vacuumed from the bottom into a shipping or an in-plant storage container (with up to one safe wet mass $235 \mathrm{U}$ per container) and transferred to a warehouse for storage. The filters from the vacuum system are placed in a safegeometry configuration and transferred to a warehouse for storage.

Personnel wear protective devices during incinerator loading and unloading operations if air ac:tivity is significant.

\section{SOURCES}

Docket 70-143, SNM 124, section 4.7 (AEC Directorate of Licensing, Washington, DC).

Docket 70-143, SNM 124, section 4.19, supplement 13 and other attachments (AEC Directorate of Licensing, Washington, DC).

Construction permit, State of Tennessee, No. 999193 I.

C. J. Michel, Manager Quality Assuranı 2 and Safet.y, Nuclear Fuel Services, written and personal communications. 
11. Babcock and Wilcox, Lynchburg, VA. For several years, combustibie wastes contaminated with small quantitites of $235 \mathrm{U}$ have been incinerated at the fabrication facility of Babcock and Wilcox in Lynchburg. The incinerator is a commercially available model with a throughput capacity of 79.45 $\mathrm{kg} / \mathrm{h}(175 \mathrm{lb} / \mathrm{h})$.

Loading. The wastes, consisting of paper, gloves, and other combustibles contaminated with $\sim 0.021 \mathrm{wt} \% 235 \mathrm{U}$ are placed in drums at the generating sites. The amount of $235 \mathrm{U}$ in each drum is determined by difference weight values, past history of material, and/or counting.

The drums are transferred to the incinerator site for storage. Waste is taken from the storage area and batch-loaded directly into the main combustion chamber of the furnace. An electrically operated guillotine door is used to close the loading port.

Incinerator Design. The incinerator has a steel shell and a plastic refractory lining. For insulation, $5.08 \mathrm{~cm}$ of mineral wool is located between the shell and lining.

The incinerator is designed to operate at $1093^{\circ} \mathrm{C}$ through use of $\Omega$ auxiliary gas-fired burner. Any unburned carbunaceous matter exhausted from the rear of the primary chamber is further oxidized by a gas-fired afterburner in the exhaust duct.

There are two observation doors on the side of the incinerato..

Off-Gas Cleanup. The gases exit the afterburner rogion into a venturi-impingement-type wet scrubber, which is designed to remove particles of $>0.5-\mu$ diam. From the scrubber, the gases pass through an induced-araft fan and are discharged at $\sim 93^{\circ} \mathrm{C}$ through a stack to the atmosphere.

The liquid bleed from the scrubber system is routed through safe-geometry lines to the contaminated liquid-waste retention tanks. No data are available on the treatment of this contaminated waste.

Ash Removal. During combustion the ashes drop through the grate into the ash chamber. When $350 \mathrm{~g}$ of ${ }^{235} \mathrm{U}$ may have been introduced into the system, the unit is shut down. When the incinerator has cooled, the ashes are removed by vacuuming the ash chamber. The vacuum-system exhaust is equipped with an absolute filter to prevent excessive airborne radioactivity in the work room. Any ash observed through the observation doors is also vacuumed periodically.
Solid ash particles are placed in drums and sent for gamma-scanning. If the amount of $235 \mathrm{U}$ is sufficiently large, the drum is sent for chemical recovery of the $235 \mathrm{U}$; if the amount of $235 \mathrm{U}$ is smail, the drum is sent to a commercial buria! site.

Containment. The front-loading area of the incinerator is located within an enclosure. To minimize the spread of $235 \mathrm{U}$ from the system during loading, unloading, and incineration, an induceddraft fan normally maintains a negative pressure with respect to the ambient conditions. During loading and unloading, operators wear respirators and protective clothing.

When the radioactivity discharged from the stack was measured during 2 months of 1973, values of $0.024 \times 10^{-10} \mu \mathrm{Ci} / \mathrm{m} /$ and $0.007 \times 10^{-10} \mu \mathrm{Ci} / \mathrm{m} /$ were obtained.

Problems. The management of Babcock and Wilcox has not discussed the incineration of radioactive wastes at this facility, so no data are available on any problems there.

\section{SOURCES}

"Paco Incinerator," North State Pyrophyllite Co., Inc., Greensboro, NC.

"The Mikro Venturi-Impingement Gas Scrubber," Pulverizing Machinery, Chatham Road, Summit, NJ.

Regulatory License, Docket 70-27, Babcock and Wilcox, July 20, 1972, April 8, 1974, Cict. 23, 1974, SNM-42, Section VII, page VII-46, VII-47a, VII-48, VII-48a, VII-49, VII-49a (AEC Directorate of Licensing, Washington, DC).

12. Yankee Atomic Electric Co., Rowe, MA. To treat low-level radioactive combustıble wastes generated during operation of the Yankee reactor, an incinerator has been operated since the late 1960's at Yankee's Rowe facility.

Pretreatment and Loading of Wastes. Combustible cellulosic-type wastes, which include paper, cloth, and shoe coverings, are collected in combustible fiber drums at the generating site. (The drums are reused until they become contaminated.) At the incinerator site, the wastes are unloaded from the crums and put manually into the incinerator. 
Incinerator Design. The incinerator has a rated capacity of $18.2 \mathrm{~kg} / \mathrm{h}(40 \mathrm{lb} / \mathrm{h})$. Air for combustion is introduced so that a vortex fow is maintained over the grate.

()ff-Gas Cleanup. From the incinerator, the offgases pass through a wet scrubber (Rotoclone), and before exiting to the atmosphere they are filtered through a deep-bed, glass-wnol filter. The liquid from the Rotoclone drain is processed with other airbearing liquid wastes. This type of waste is collected in two 5185-/ (1370-gal), monitored taniks. Depending upon their activity, the liquids may be either discharged through a disposable-cartridge filter to the cooling water effluent or processed by evaporation techniques.

Ash Removal. Ash is iemoved from the incinerator through a cone which connects to the top of a $242 . /$ steel drum half-filled with water. When the drum contains about 18 batches of ash, two sprays thoroughly wet the ash. The liquid is then decanted from the settled ash and the ash is solidified by the addition of cement. The drums are then shipped to appropriate burial sites. About two drums of incinerator ashes are produced each year. Decant liquid is treated along with other air-bearing liquid wastes.

Problems. The system reportedly has worked well during the period of operation of the reactor. Large amourits of plastics are excluded from the wastes to be incinerated because their inclusion caused poor combustion.

\section{SOUHCES}

M. I. Goldman, "United States Practice in Management of Radioactive Writes at Nuclear Power Plants," in Managerent of Radioactive Wastes at Nuclear Power Plants, IAEA Safety Series No. 28 (1968), pp. 196-203.

1. Seybold, Yankee Atomic Electric Co., persona? communication.

\section{Kerr-McGee Nuclear Corp., Crescent, OK}

a. Calciner for Plutonium Recovery. Fr.s some years a calciner has been operated at Kerr-McGee's facility at Crescent to treat wastes that are contaminated with fairly large amounts of plutonium. The plutonium can then te leached and recovered from the residue.
First facility. The facility las undergone several modifications since it was first constructed. Initually, it consisted of an Inconel metal tube $2.13 \mathrm{~m}$ long and $-25.4 \mathrm{~cm}$ in diameter. A small glove box was located at each end of the tube. A wafne-like centes divider ran the length of the tube.

The center $1.2 \bar{m}$ of the tube was heated to $\sim 750-800^{\circ} \mathrm{C}$ by electrical heating eiements. Air entered at one end and off-gases from the calcining left at the other end of the tube. In the exit glove iox, the gases passed through a tar trap, and into the main filtration system. Doors were fitted to the ends of the tube. The entry and exit sections of the tube were air-cooled. The cooling air exhausted through HEPA filters.

Small trays, $2.5 \mathrm{~cm}$ deep, $30.5 \mathrm{~cm}$ long, and 23 $\mathrm{cm}$ wide, were filled with combustibles in the entry glove box. The doot to the tube was opened and the tray placed in the tube. While the trays were being pushed through the pipe, the hydrogen and carbor were dissociated. Trays were unloaded in the glove box at the other end of the tube. The ash was loaded into safe-geometry containers and sent for plutonium recovery. Trays were returned through an overhead tunnel.

Modifications. The procedure was later modified so that the waste would actually be burned. Sr " screen baskets were built to hold the waste. The doors were removed, and a fire screen was placed over the exit end of the tube. Air was fed into the entry glove box. and the wexte was ignited with a torch. Usually the fire was started with cheesecloth and Kimwipes. Later such itenns as polypropylene filter cloth might be added.

The gases exited through the fire screen inio the glove box, and then into the main gas-filtration system.

The ash fell into a pan. Combustibles were burned until the permissible concentraiion of plutonium was in the system, then the ash was removed, placed in containers of safe geometry, and sent for recovery.

The burning of the waste tended to plug the filters because complete combustion was not possible. Therefor, in 1971 the systam was returned to cperation as a calciner.

Present Operation. The tar trap is no longer used. Sufficient air flow, $\sim 0.0038 \mathrm{nf}^{3} / \mathrm{s}(8 \mathrm{cfm})$. is provided to minimize production of soot and tars. Nitrogen purge for the glowe boxes hes always bzen available, although apparently there has been no serious burn-back into the glove box during either type of operation. No halogenated materials are processed in the calciner; thus, corrosion by $\mathrm{HCl}$ or 
HF has not occurred. The PVC used in the facility is leached before being buried.

\section{b. Incinerator for Uranium-Containing Wastes} During processing ectivities at the Oklahoma plant of Kerr-McGee, combustible wastes containing uranium enriched to $2-3 \%$ 225 (J) are generated. Since Juty 1972, these combustible wistes have been incinerated so ihat the uranium may be recovered after further processing of the ash. No $\mathrm{PVC}$ is incinerated (very little is used in the Uranium Plant).

Pretreatment of Wastes. Combustible wastes containing uranium are collected in polyethylene bags, compacted, and gamma-counted to obtain the amount of $235 \mathrm{U}$ in each bag. The bags are stored in drums.

Loading. When enough waste is in storage to approach the $250 \mathrm{~g}$ allowable limit for $2.25 \mathrm{U}$ in the incinerator syst $n, a$ burn is made. One bag weighing about i8.2 kg ( $40 \mathrm{lb})$ is placed manually in the incinerator ( $\sim 4$ bags/ $h$ can be burned). Incineration of the bags continues until the limit for $235 \mathrm{U}$ is reached. As many as 100 or more bags may be incinerated during one run.

Incinerator Design. The incinerator includes a primary and a secondary refractory-lined combustion chamber. Two gas burners are used for auxiliary hest. Maximum exhaust temperature from the incinerator is $204^{\circ} \mathrm{C}$.

Off-Gas Clecinup. Gases go from the incinerator into a cleanup train. Dilution air can be added if needed to control temperature. The gases and entrained soot and particulates pass through a baghouse and filters before emission to the ambient atmosphere.

Ash Removal. When a burn has been compleied, the incinerator is allowed to cool, and the ashes then are removed by a vacuum nozzle into a safa container by operators wearing full-face respirators.

The low temperatures in the incinerator result in incomplete combustion; therefore, before the residue is sent for uranium recovery the incinerator ashes must be placed in a muffle furnace for $\sim 12 \mathrm{~h}$ to reduce the carbon content further.

Performance. Approximately 45 days/yr are reyuired for maintenance. In $1 s i 2,55$ burns werc made; in 1973, 33 burns were made; and in 1974, 52 hurns were made. Refractory losses have been $\sim \mathbf{4 0 \%}$ since start-up.
Problems. One fire occurred in the baghouse. probably because too large a load was put in the incinerains and soot collected on the baghouse and caught fire. A limit tiuk tas heen placed on how much oil, plastic, and paint can be chargeu to the incinerator.

\section{SOURCES}

W. J. Shelley, Director Regulation and Control. Kerr-McGee Nuclear Corp., written and personal communications.

R. Mulkin, LASL, personal communication.

14. Los Alamos Seientific Laboratory (LASL), Los Alamos, NM

a. Incinerator for Plutonizm Recovery. A small incinerator has been successf:tlly operated at LASL fo: a number of years. The primary purpose of this incinerator is the recovery of plutonium from contaminated wastes. At the same time, there is, of course, a large reduction in volume of the wastes.

The first incinerator was installed at LASL in 1952 and was rebuilt in 1959 . The main modifications in 1959 were (1) attachment of the top of the incinerator to the bot om of the glove box so that it was easier to inspect the system visually, and (2) inclusion of a vent system for release of excessive pressure. This modified unit has been used on a batch basis almost continuously.

At present, about eight batches are burned each week, but should the need arise the throughput can be increased to one burn about once every $2 \mathrm{~h}$.

Pretreatment of Wastes. Some presorting and treatment is done at the generating site. Noncombustibles are excluded from the bags destined for the incinerator. In addition, all rags that may have been used to wipe up $\mathrm{HNO}_{3}$ are supposed to be rinsed in water after each use. if this rinse procedure is followed, wastes should not contain any nitrocellulose.

Waste is sent to the incineration facility in a tightly sealed PVC bag placed in a steel drum. The steel drum is introduced into the main glove-box line which serves the incinerator.

The operator transfers the drum to the working area and opens it. The wastes are separated into the following categories: (1) noncombustibles, (2) plastic bags and rubber gloves, and (3) cheesecloth, cotton rags, cardboard, and wood. Categories 1 and 2 are gamma-scanned; if they appear to be below the limits for plutonium recovery, they are sent to a 
measurement station where the plutonium content is measured. If below the discard limit $11 \mathrm{~g} \mathrm{Pu} / 1 \mathrm{~kg}$ wastel, the wastes are packaged and $5 \leq n t$ to retrievable storage (as presently defined). If the gamma-scanned wastes are above the discard lir. they are placed on a trolley and sent to another sec. tion of the glove-box line for leaching with $\mathrm{HNO}_{3}$ to recover the plutonium. After leaching, the articles are scanned again. Should any of the plastic bags or rubber gloves have hot spots, the spots are cut from te material and sent to the incinerator along with the items in category 3 . The remaining material is sent for nondestructive analysis and then to retrievable storage.

The items in category 3 , and the previously described pieces from category 2, are accepted for incineration. Until recently, any wet rags were spread iis the glove box until fairly dry. However, a set of rags was: received that had not been adequately rinsed with water after use with HNO. . These ignited spontaneously in the glove box. An emergency sprinkler system, installed in the main areas of operation in these glove boxes, floods the area with a predetermined amount of water. When the fire started, it was quenched by this sprinkler system before any gloves caught fire, and the glove box was not breached. As an added safety measure, all rags are currently being dried in the incinerator basket

Some years ago, graphite was incinerated, but this is ro longer necessary because coatings on the graphite now prevent plutonium penetration of the crucible walls. Now the plutonium can be removed more efficiently by leaching with $\mathrm{HNO}_{3}$ than by incineration.

Loading. The sorted objects are loaded manually, through a glove box, into a basket. The basket (Fig. 40) is constructed of 316 stainless steel with a solid 12-gauge pan at the bottom and with open screen sides (No. $4 \mathrm{mesh}$ ). It is a cylinder $25.4 \mathrm{~cm}$ in diameter and $25.4 \mathrm{~cm}$ long and holds $12 /(700-1000$ g) of material.

Incinerator Design. The loaded basket, held by a stirrup hanging from the perforated reflector plate, is lowered into the main burn chamber. (The reflecinr plate is attached to a plate on the burningchamber lid.) This basket assembly is raised and lowered by means of an air cylinder. Suitable flanges and a water-cooled gasket insure isolation of the burning chamber from the glove box when the lids are in place. The burning chamber, hasket. and bubbler are shown in Fiz. 41.

The burning chamber itself is a $0.32 \cdot \mathrm{cm}$-thick tube, $3 n .48 \mathrm{~cm}$ in diameter and $46.98 \mathrm{~cm}$ long, with a

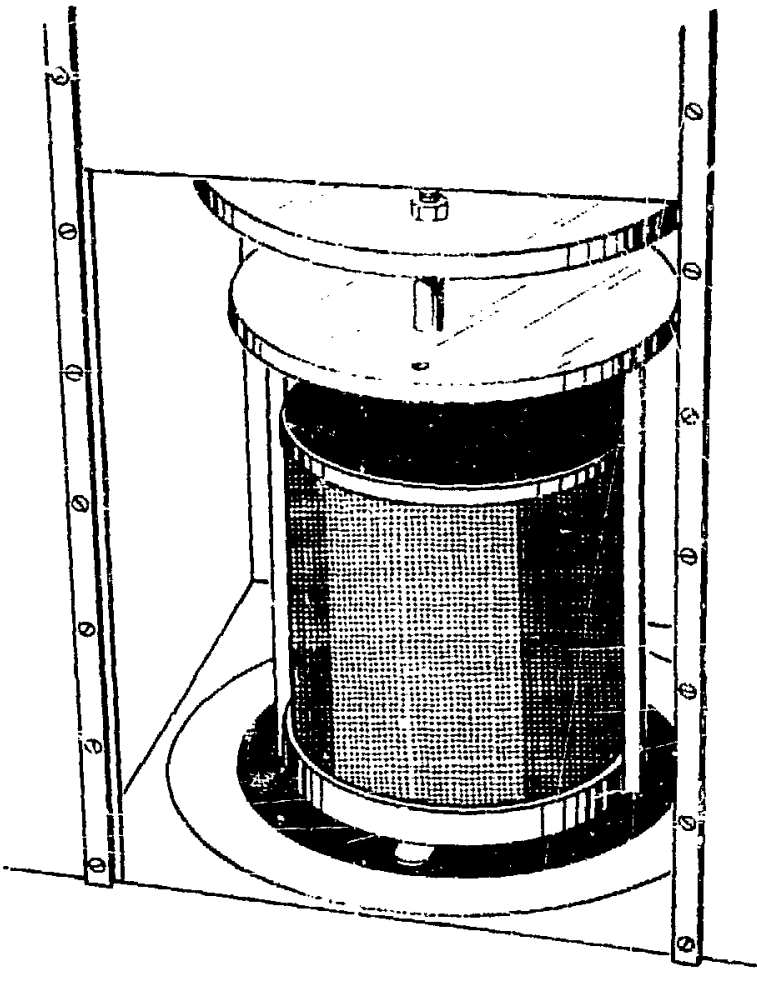

Fig. 40.

Loading basket of plutonilim-recovery incinerator at Los Alamos. 1952.

flanged top and conical bottom. It is constructed of 316 stainless steel. Eighi 250.W strip heaters are attached to the outside. The urit is insuleted with asbestos. Air and oxygen, metered through a rotantier, enter the burning chamber through a pipe between the lid and reflector plate. Helow the reflector plate is a steam line which can be user to clean the chamber. Thermocouples are located in the wall area of the chamber.

Once the material has been loaded and the basket positioned inside the burning chambel, the heaters are turned on and air is circulated through the chamber at the rate of $0.0014-0.0024 \mathrm{~m}^{3} / \mathrm{s}(3-5$ acfm), as measured by the rotamuter, uritil most of the moisture has evaporated. The operator can check on the dryness of the basket's content by removing the basket and checking the contents in the glove box.

Once the drying has been completed and the thermocouples indicate a suitable temperature, the operator ignites the charge with a match. The material is oxidized at this time by adding 0.0005 $\mathrm{m}^{3} / \mathrm{s}(1 \mathrm{acfm})$ of pure oxygen into the chamber. 


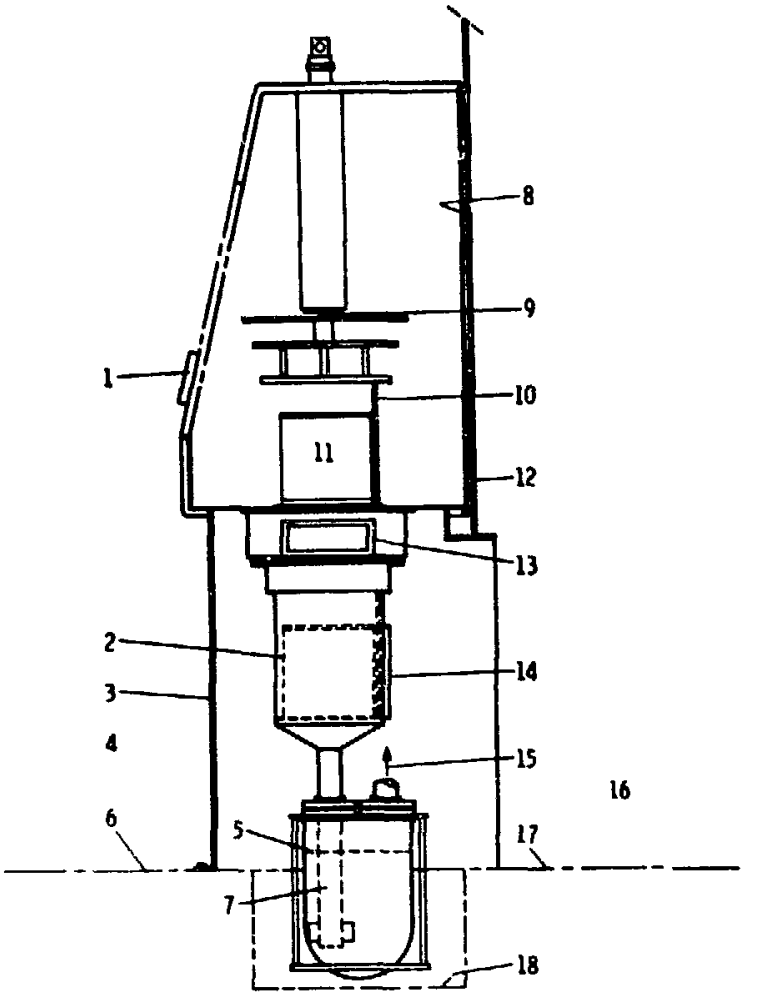

1. Working gloves at $1.27-m$ height

2. Basket in burn position

3. Stainless-steel plate as contamination and explosion barrier

4. Normal working area

5. Liquid level

6. Floor level

7. Bubbler tuba

8. Back wall of glove box
9. Air cylinder shaft
10. Basket carrier
11. $12-\ell$ burn basket
12. Contamination barrier
13. Pressure-relief duct
14. Electrical resistance strip heaters is used)
15. Off-gases through condenser to filter and vacuum system
16. Equipment area
it. F'cor level
18. Pit level

Fig. 41.

Burning chamber of incinerator at Los Alamos, post -1960 .

Toward the end of the burn, the oxygen flow can be shut off and the chamber allowed to cool. Then the basket can be removed manually and the residue stirred.

The temperatures in the basket are not recorded; consequently, the combustion temperatures in the bed are not accurately known. However, a mockup of the facility has been run with "cold" material. Thermocouples were placed in the bed (burn basket) as well as on the sides of the chamber. Data obtained from the mockup runs indicate that the material burns at $\sim 800^{\circ} \mathrm{C}$.
Off-Gas Cleanup. Oxygen enters the top of the chamber and moves downward through the basket. As the oxidation proceeds downward through the bed, the off-gases move downward and heat the unburned residue. Finally the gases exit the chamber through \& stainless-steel bottom tube equipped with fins. The gases are then bubbled through (by means of a gas sparger) a water-filled glass vestsel (Figs. 41 and 42). The bubbling is vigorous, with a great deal of turbulence. In this vessal, much of any acid gas such as $\mathrm{HCl}$ is removed along with the larger-sized particulates. After a short time the water becomes cloudy.

From the bubbler, the gases pass a Teflon expansion joint and enter a cooler-condenser tube of 316 stainless steel (Fig. 42). It is cooled around its outer sides by water at $12.2^{\circ} \mathrm{C}$. In this tube the gases cool and water condenses and runs back to the

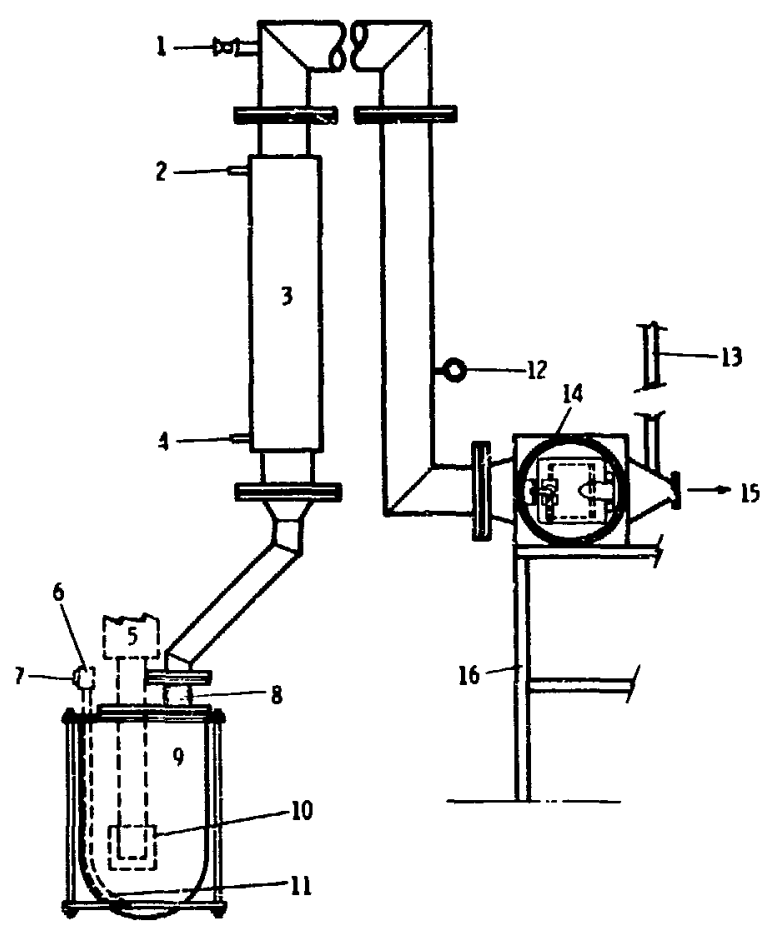
1. Blecder välve
2. Cooling water in
3. Cooling column
4. Cooling water out
5. Finned section
6. To water line
7. To withdrawal line
. Teflon expansion joint

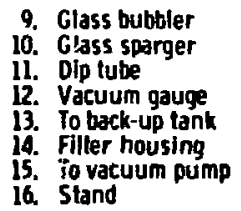

Fig. 42.

Cleanup system of incinerator at Los Alnmos, NM. 
bubbler. Next, the gases pass through a stainlesssteel tube, where some warming occurs, to a filter and through the Nash vacuum pump system (Fig. 43). In the seal tank, the slightly caustic $(1 \% \mathrm{NaOH})$ liquid used in the seal line separates from the gases, and the gases then vent into the plant process airexheust system.

Once the gases are in the main air system, they must. pass through two sets of HEPA filters before exhaisting to the ambient air. Any remaining small particulates are removed in these filters.

When the operator has placed the basket in the burn chamber, he starts the vacuum pump and adjusts the bleeder valve above the cooling column until vigorous bubbling can be seen in the glass bubbler. In this way, the operaior insures that the burning chamber is not operating under positive pressure during normal drying and combustion and that turbulence is occurring in the bubbler. Visual observation of the bubbler is very important.

Ash and Residue Removal. When the burn cycle is complete and the chamber is cool, the basket is removed. The cool ashes can be placed in a small ball-mill located in an adjacent glove box. After the

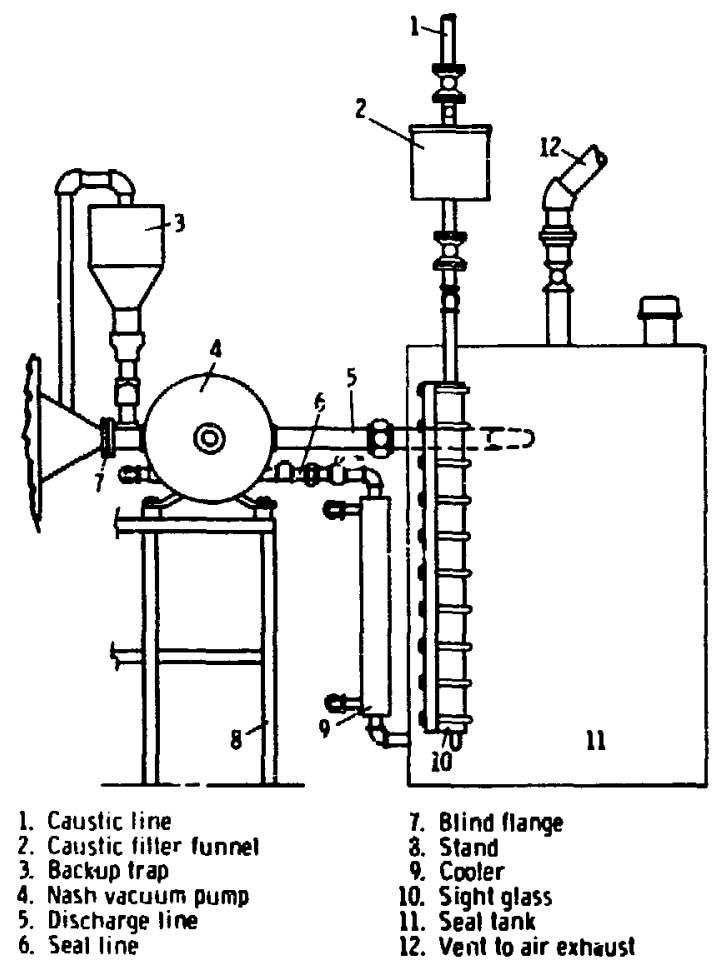

Fig. 43.

Vacuum pump system of Los Alamos in. cinerctor. ashes have been pulverized to a fine powder ( 20 mesh), they are placed in a jar for storage. The jar is so sized that if all the ash were $\mathrm{PuO}_{2}$, the ash would at no time approach a critical mass. From the area of the ball-mill, the ash is transported by trolley down the glove-box train into the leach facility. In this area, the recovery of the plutonium from the ash begins by subjecting the ashes to successive leaches.

The 17 i of bubbler solution are removed after about five runs, and the solution is filtered through a sintered glass disk. This filter removes particles of $\geq 10-\mu$ diam. The solid-type residue is then processed with the ashes. An aliquot of the filtered liquid is taken, dried, and counted. Should the data indicate the presence of $>1 \mathrm{mg} / /$ of plutonium, the liquid is treated further. If there is $<1 \mathrm{mg} / /$ of plutnniunı, the liquid is placed in the active drain and sent to the iron-flocculation treatment facility. In general, because the particulates trapped in the bubbler are usually $>10-\mu$ diam, and because most of the plutonium is not in the form of water-soluble compounds, the liquid from the bubbler contains $\sim 7 \mathrm{x}$ $10^{-4} \mathrm{~g} / \mathrm{t}$ of plutonium after filtering and can be placed in the active drain.

The 151 / of seal solution are replaced about once every five batches. This solution is also sampled and usially contains very little (average of $5 \mathrm{x}$ $10^{-5} \mathrm{~g} / \mathrm{h}$ plutonium. After any necessary acidification, the seal solution can be placed in the active drain and sent for final cleanup at the ironflocculation facility.

On the average, $\sim 10 \mathrm{~g}$ of plutonium are in one burn basket of waste. During incineration, $\sim 10 \mathrm{mg}$ of this plutonium are taken out in the scrub solution as soluble plutonium compounds. About $3 \mathrm{mg}$ are removed in the seal solution and $\sim 10 \mathrm{mg}$ are retained on the filter. The scrub solution is filtered and $\sim 55 \mathrm{nig}$ of insoluble plutonium are removed by the filter and added to the ash from the basket for ballmilling and plutonium recovery. The remaining $\sim 9.95 \mathrm{~g}$ of plutonium are found in the ash from the basket. The filtered plutonium is added to the ash. so almost all the plutonium in the waste is sent for recovery.

Containment. The burning chamber and off-gas system are in a room that is separated from the operating area by metal wall partitions and glove boxes. The room in which the off-gas system is located is maintained at a negetive pressure relative to the operating area. Moreover, once a burn begins. the room is locked and no one can enter. Should a gasket leak or an expansion joint or pipe crack, the contamination should be contained in the locked room and air-venting system. If the bubbler glass 
should break, or the seal tank leak, the water is contained in a well which surrounds the lower part of the bubbler vessel and can be vacuumed up.

Loading and unloading of the charge basket, ball-milling of the ash, and withdrawing and handling the water bubbler solution are all done in the glove box by the operator. These boxes are at slightly negative pressure relative to the operating area.

When pressure excursions occur in the burning chamber, several safeties allow for pressure relief. If a small excess pressure occurs, the gases simply flow more rapidly through the bubbler. If moderate excess pressure occurs, not only is there a greater volume of gas through the cleanup system, but aiso the plate below the top seal plate on the burning chamber is pushed up slightly. This leaves a small space through which the gases can vent through a vent line installed there. Should a large pressure exursion occur, the bubbler will crack. Excess gases should then vent into the locked room. Major pressure excursions have been caused by rapid combustion of nitrocellulose which is formed if $\mathrm{HNO}_{3}$ is not quickly washed from the cheesecloth rags.

Maintenance. As mentioned earlier, a steam line is used to clean the main combustion chamber. Accumulated tars on the walls of the bubbler and on the cooler tube, etc., can be removed with trichloroethylene. However, only small amounts of PVC, or other plastics, or rubber are burned, and tar removal is necessary in the cleanup system only about once a year. The burn chamber itself has not been steam-cleaned in $7 \mathrm{yr}$.

The filter, after the cooler, is changed about once every 6 months. The filter is located in a housing that permits filter-changing by the standard plastic-bag technique.

The burn chamber has not been replaced since 1959. The burn basket itself does corrode and scale, and must be replaced occasionally.

The glove boxes are cleaned periodically. The rest of the system has had no major repairs since its modification in 1959. Thus, little maintenance is necessary in the present operation.

Problems. No major problems have been found. The main concern is with the possible presence of nitrocellulose in the wastes, hence the glove-box operators are required to rinse every rag containing $\mathrm{HNO}_{3}$.

When the incinerator was first built it was intended that rubber gloves and PVC would also be burned. In actual operation, incineration of large amounts of rubber gloves and plastics resulted in such large quantities of tars in the scrubber and offgas !ines that the filter plugged after one or two runs.
In addition, the off-gas lines were quickly coated with tars. Corrosion from $\mathrm{HCl}$ formed in the combustion of PVC also increased markedly. As a result, the amount of plastic or rubber that could be burned was restricted to only those pieces that still contained appreciable quantities of plutonium after being leached with $\mathrm{HNO}_{3}$.

There is little migration of plutonium into the sides of the burn chamber; also, no buckling or cracking of the chamber walls has been observed.

Discussion. This incinerator has operated for many years with only minor repairs and modifications. This is due, at least in part, to the foliowing features.

(1) Burn basket. The use of a burn basket prevents excessive migration of plutonium into the walls of the burn chamber. Moreover, the temperatures at which combustion takes place $\left(800^{\circ} \mathrm{C}\right)$ can be much higher than the wall temperatures in the burn chamber (uppei part $105^{\circ} \mathrm{C}$, lower $\sim 225^{\circ} \mathrm{C}$ ). Thus, stainless steel can be used.

(2) Use of oxygen with batch operation. The dewnward flow of oxygen through the basket permits oxidation of the material in the region of the bed and makes unnecessary a great deal of turbulence in the gases throughout the chamber. The use of oxygen also minimizes the amount of additional heat required and the quantity of off-gases that must be treated.

(3) A charge of almost uniform composition and heating value, devoid of plastics and rubber. The uniformity of the charge means that fewer temperature and pressure excursions will occur. Moreover, exclusion of large amounts of rubber and plastics allows combustion at lower temperatures without the production of large quantities of tar and soot. The exclusion of PVC precludes the presence of $\mathrm{HCl}$ in the off-gases, while exclusion of rubber reduces the amount of $\mathrm{SO}_{3}$ formed.

(4) Bubbler. The use of a water quench prevents filter fires.

(5) Nash pump. A Nash pump permits further gas cleaning while providing a reliable pump system.

(6) Containment. Use of a glove box for loading, unloading, and handling of ashes and bubbler water and the use of a closed room for the off-gas system minimize the spread of contamination.

b. Future Incinerator for Plutonium Recovery. A new plutonium-processing facility is now being built in Los Alamos. Because the old incinerator has been so successful and because it can achieve a throughput adequate for the new facility, an incinerator system of the same design, size, anu 
materials of construction wili be used in the new facility. The only modificaticins will be in the sealsolution tank and glove-box arrangement.

The shape of the seal-solution tank will be slightly changed for purposes of criticality control; $i$ will be $20.32 \mathrm{~cm}(8 \mathrm{in}$.$) in diameter and 213.4 \mathrm{~cm}(7 \mathrm{ft})$ long.

The glove boxes will have additional lead shielding so that larger quantities of plutonium can be handled without exposing the operator to excessive levels of radiation. In addition. the airventing system will be arranged differently and it will be easier to effectively introduce an inert gas into the area in case of fire.

\section{SOURCES}

W. D. McNeese and W. J. Maraman, "Incinerator for Radioactive Residue," Los Alamos Scientific Laboratory report LA-1691 (March 1954).

E. L. Christensen and W. J. Maraman, "Plutonium Processing at the Los Alamos Scientific Laburatory." Los Alamos Scientific Laboratory report LA-3542 (April 1969), pp. 44-47.

W. D. McNeese and W. J. Maraman. "Incinerator for Radioactive Residue," Ind. Eng. Chem. 52, 79A81A (1960).

E. Christensen, LASL, personal communication.

On-site visit by $B$. Perkins.

c. Experimental Program on Incineration. A development program has been initiated at LASL to study selected production-level volume- and massreduction processes for the treatment of transuranic solid wastes. This program will include a study of incineration. An initial prototype incinerator is now beginning operation.

Loading. The feed will include wastes similar to the solid combustible wastes (including PVC) com. monly coming from facilities processing radioartive materials. Batch feed will be charged by a ram feeder, and shredded feed will be blown tangentially into the lower chamber through a flanged, $15.24-\mathrm{cm}$ (6-in.)-diam nozzle.

Incinerator Design (First Prototype). The twochamber incinerator now installed at LASL is a com mercially available, controlled-air incinerator designed for a throughput of $\sim 45.4 \mathrm{~kg} / \mathrm{h}(100 \mathrm{lb} / \mathrm{h})$. Ram-fed waste introduced into the primary chamber
(2.4 $\mathrm{m}$ long and $1.8 \mathrm{~m}$ in dismeter) burns on the floor of the chamber. This chamber is normally operated under a starved-air condition, with underfire air entering through air ports (four on each side of the chamber and spaced a short distance from the incinerator floor). A prenixed natural-gas burner provides the additional heat needed to maintain the proper operating temperature of $540-815^{\circ} \mathrm{C}$.

As the gases exit the primary chamber, air is added through a port located between the two chambers, and the unburned volatile components and entrained solids undergo further oxidation in the secondary chamber. This chamber is also equipped with a premixed natural-gas burner located close to the gas entry. Operating temperatures are expected to be $1000-1500^{\circ} \mathrm{C}$. Air introduction rates, as well as chamber temperatures, will be varisd according to waste composition.

The chamber shells and other primary struc. tural components are of carbon steel. The two chambers and the exhaust duct immediately downstream of the upper chamber are lined with $12.7 \mathrm{~cm}$ of high-density, $1649^{\circ} \mathrm{C}$ plastic refractory backed with $5.08 \mathrm{~cm}$ of mineral-wool block. (A temperature of $121^{\circ} \mathrm{C}$ is predicted for the exterior surface when the interior chamber is operating at $1093^{\circ} \mathrm{C}$ continuous service.) A 5-mm-thick. industrial mastic stack coating containing chlorosulfonated rubber is applied between the refractory and the metal shell of the incinesator to protect the metal surface from corrosive attack by acid gases.

Off-Gases. In the initial prototype installation the gases currently exit the secondary chamber directly into the mastic-coated, refractory-lined stack. No radionuclides are to be included in the waste in this prototype; consequently, no off-gas cleanup system is planned. Later, a damper will be installed in the stack.

Ash Removal. Ashes accumulated during combustion drop through an orifice in the chamber floor or are vacuumed from the combustion chamber.

Safety. Combustion controls assure that the natural-gas supply is disconnected shuuld hameout or power failure occur. In the event of burner shutdown, waste combustion normally will continue at a reduced rate sustained by air induced by natural draft. Additional safety features include interlocks on the feed system. Waste cannot be introduced when lower chamber temperatures are above or below preset limits. Further, an ultraviolet flame sensor installed in the ram feeder activates a waterspray system should burining material adhere to the 
retracting ram face. Interlocks on the guillotine feed dorer and ash-removal door prevent continued operation if the dorrs are not properly closed.

Operation Objectives. Operation of the first prototype incinerator will determine:

(1) System modifications necessary to meet radiological health and safety standards;

(2) Operating conditions necessary to achieve maximum possible combustion of anticipated waste components:

(3) Composition of incinerator off-gases and the nature of particuiate effluent as a function of waste type and operating conditions;

(4) Satisfactory methods ior feed introduction and ash removal;

(5) Optimum feed prepsration method; and

(6) Off-gas cleanup requirernents.

Future Prototype Incinerator. A building is under construction at LASL to house test facilities for treatınent of contaminated waste. The test facility for inciseration will include (1) package assay, sorting, and feeding equipment, (2) incinerator, and (3) off-gas clesnup train. The type of sorting. feeding, and incineration to be tested first will be determined from data now being obtained with the present prototype incinerator.

The first off-gas cleanup system to be tested already has been designed, using theoretically derived flow rates, particulate loadings, etc. The following cleanup sequence will be used: (1) quench chamber, (2) variable throat venturi scrubber, (3) packed column, (4) water-cooled condenser, (5) heater, (6) roughing filter, and (7) two HEPA filters.

The quench chamber will be equipped with water sprays to cool the gases as far as saturation conditions will allow. Because of the high temperatures, the entry area of this chamber will be constructed of Hastelloy $\mathrm{C}$. The main area will be lined with dry, laid brick; the spray nozzles will be of Hastelloy. The vessel shell itself will be made of fiber-glass-reinforced plastic (FRP), a material resistant to attack from acids and bases and with $\mathrm{e}$ maximum recommended service temperature of $120^{\circ} \mathrm{C}$. At the bottom of the quench chamber will be a receiving, pot to remove large water droplets.

After cooling, the saturated gases will pass through a variable throat venturi scrubber, where much of the particulate matter and some of the acid gases will be removed. The throat will be lined with Hypalon rubber to reduce erosion in this area. The rnain body of the scrubber will be constructed of FRP.
From the venturi, the gases will pass through a tangential disengaging unit for removal of entrained droplets, then through a packed column that wili operate as a countercurrent scrubber using fresh water. In this column most of the $\mathrm{HCl}$ should be removed, along with some of any other acid gases that may be present. The packing in the column will be $30.5 \mathrm{~m}(10 \mathrm{ft})$ high and made of polypropylene. The main vessel itself will be FRP. At the top of the column, a demister pad will remove entrained mist.

The gases will pass next through a water-cooled condenser, a heater, and into an extended-surface roughing filter. Finally, they will pass through two sets of HEPA filters in series for removal of any fine particulates before being exhausted to the ambient air.

The scrub solution will go through a graphite, water-cooled heat exchanger and then through a full-flow liquid filter before being recycled to the quench chamber and venturi scrubber. Scrub solution blowdown will enter a holding tank where caustic may be added hefore discharge to the LASL liquid-waste treatment facility.

Process cooling water will be circulated to an evaporative cooling tower, thus permitting recycling of the cooling water and ninimizing water usage.

The off-gas cleanup train has been designed so that various units can be removed or new units added; thus. components of the system can be studied.

Developmental Program. The test facility will test feed preparation and loading techniques. The incinerator will be operated and tested in conjunction with the off-gas cleanup train.

While the incineration test program will initially be run using nonradioactive wastes, some slightly contaminated material will be burned later. The permissible limit on the total amount of plutonium is $100 \mathrm{~g}$ for the building.

\section{SOURCES}

Los Alamos Scientific Laboratory, "Transuranic Waste Research and Development Program, Semiannual Report, July 1974 - December 1974," to be issued.

"Process Design Criteria and Conceptual Design for the Transuranic Waste Reduction Treatment Development Facility," Los Alamos Scientific Laboratory internal document.

"Conceptual Design Report for the Transuranic Contaminated Solid Waste Treatment Development 
Facility TA-50," Los Alamos Scientific Laboratory internal document, September 4, 1973.

On-site visit by B. Perkins.

J. A. Mohrbacher, LASL, memorandum.

\section{Mound Laboratory, Miamisburg, $\mathrm{OH}$}

a. Plutonium-Recovery Incinerator. For many years a small incinerator has been used at Mound to incinerate plutonium-contaminated combustible materials so that plutonium can be recovered from the ash. The first facility was identical to the one previously described for plutonium recovery at Los Alamos (Sec. III-B-14-a).

Several years ago a new building was constructed at Mound, and a new plutonium-recovery incinerator was built. The basic size and design of the old incinerator were retained, but some modifications were made in the mode of operation and in the off-gas cleanup system.

Pretreatment of Wastes. At the present time, when wastes are generated at the various stations in the process lines, they $a_{1}$ e packaged in 4.4-/ (1-gal) cartons. As at Los Alamos, rags that have been used to wipe up $\mathrm{HNO}_{3}$ are washed with water and are usually dried before bagging.

Once the wastes are packaged, they are moved by conveyor to the gamma-scan laboratory to determine whether they should go to recovery or be discarded. Only discardable wastes are removed from the line. Wastes having recoverable amounts of plutonium are then sorted. Accepted for incineration are polyethylene (such as film), rags, paper, and wood. No glove-box gloves are accepted and neither is PVC.

Loading. The acceptable wastes are loaded into the burn basket in a way similar to that described for LASL. If any wet rags appear, they are distributed throughout the loads during the day. Usually, wastes from about three 4.4-/ cartons are loaded into the basket for the first burn.

Incineration. After being loaded, the charge is ignited by a match, and the material in the basket is incinerated. Then the basket is removed and more material is added. The waste in about twenty 4.4- $/$ cartons is usually fed to the incinerator in one day. At the end of the day, or when the pan is full of ashes, the system is allowed to cool.

Off-(ias Cleanup. From the incinerator, the gases exit at a temperature of $\sim 649^{\circ} \mathrm{C}$. They are then cooled in a water-cooled heat exchanger before passing through the bubbler vessel and into the gas cleanup system for the building.

The building's gas cleanup system consists of a caustic scrubber tower, a Brink mist eliminator, casson filter, and a HEPA filter.

The spent bubbier solution is filtered to remove insoluble plutonium-containing compounds and other particulates. The solution is then sampled. Usually, so little plutonium remains that the solution can be discharged to the waste-handling facility.

Residue Removal. The morning after a burn, the conl ashes are removed from the pan at the bottom of the basket and put through an 80-mesh screen. The old bubbler water is removed and new water is added.

Performance. In the current Mound operation, air is used instead of oxygen during burning of the wastes. Although higher temperatures were observed when oxygen was used, combustion was just as complete, as far as the ash was concerned, when air was used. Moreover, pressure excursions are not as extreme when air is used. Some tar deposition does occur in the off-gas system, but the problem is not a major one.

Problems. As at LASL, no major problems are reported for this plutonium-recovery incinerator. The burn basket must be replaced periodically. At first, the heat exchanger plugged, but that was overcome by replacing it with one that had tubes of larger diameter. Propane ignition was tried at one time, but it was decided that a match was safer.

Mound uses the same pressure-relief, lid-vent system as that described for LASL. Occasionally, the pressure-relief outlet is used, but no serious explosions have occurred.

As at LASL, the disadvantages of the system are (1) low throughput capacity, and (2) limitations on the types of combustible materials accepted for incineration.

\section{SOURCES}

D. Luthy, Recovery Operations, Mound Laboratory, personal communication.

W. T. Cave, Director, Nuclear Operations, Mound Laboratory, written communication.

S. Freeman, Mound Laboratory, personal communication. 
J. Todd, Mound Laboratory, personal communication.

b. LSA Development Incinerator Program. At Mound Laboratory, a cyclone-type incinerator that uses a tangential air supply is under development. It will be used to incinerate LSA $(<100 \mathrm{nCi} / \mathrm{g})$ wastes consisting of waste paper, shoe covers, rags, and possibly PVC and polyethylene.

Prepilot-Plant Studies. Initially, a 242-/ drum was set up outdoors. When it was filled with com bustible material (excluding plastics) and the wastes burned, using a tangential-type air feed, there was no visible plume. When plastics were included, a faint plume resulted.

Pilot-Plant Design. The results of these outdoor tests led to the design and fabrication of a small pilot-plant incinerator system that includes off-gas cleanup as well as a cyclone-type incinerator.

The incinerator, constructed of stainless steel, is located in a fume hood. The general layout is shown in Fig. 44. Induced air is fed tangentially into this vessel; the ash residue falls to the bottom where an ash-removal system can be installed.

From the incinerator, the off-gases pass into a deluge tank, where they are neutralized and cooled by an alkaline water spray.

From the deluge tank, the gases pass through a roughing filter where the largerentrained droplets of mist and particulates $(>3 \mu)$ are removed. The roughing filter is continuously irrigated with alkaline

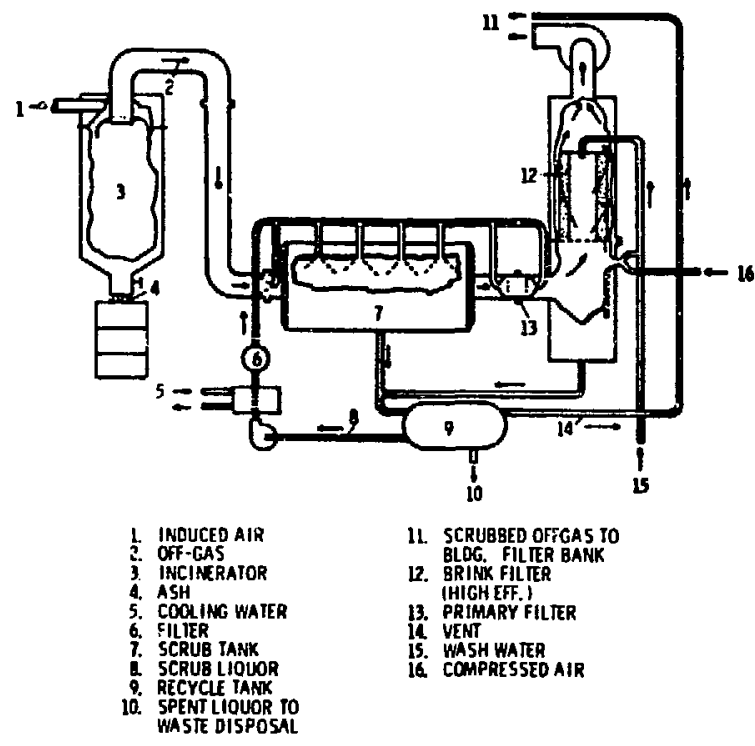

Fig. 44.

Cyclone incinerator at Mound Laboratory. water to prevent clogging and provide additional scrubbing. The gases pass next through a Brink mist eliminator (deep-bed fiber filter) for removal of the fine mists and particulates $(<3-\mu$ diam) not removed in the roughing filter. The mist eliminator is irrigated continuously with fresh water.

From the mist eliminator, the gases pass through the exhaust fan and then discharge to the exhaust header leading to the filter bank. The pressure drop of the complete system is $\sim 5000 \mathrm{~Pa}$ (20 in. water gauge) for a flow of $94.4 / / \mathrm{s}(200 \mathrm{scfm})$.

The liquor from the deluge tank, roughing filter, and mist eliminator is passed through a water-cooled heat exchanger and a bag-type filter, and then recycled to the off-gas treatment system. Currently, $\mathrm{Na}_{2} \mathrm{CO}_{3}$ is added to the system for neutralization.

This pilot-plant incinerator has been in operation for only a short time. At present, it is packloaded with combustible material which is ignited manually. Gas-flow patterns, burn rates and temperatures, ash characteristics, and off-gas cleanup performance are being studied.

The incinerator is similar in design to the BOMAEC-30 discussed in Sec. III-A-8, but the offgas cleanup train is different.

\section{SOURCES}

S. Freeman, Mound Laboratory, personal communication.

W. T. Cave, Liiector, Nuclear Operations, Mound Laboratory, written communication.

J. Todd, Mound Laboratory, personal communication.

Drawing, LSA incinerator.

\section{Rockwell InternationaI, Rocky Flats, CO}

a. Plutonium-Recovery Incinerator. At the Rocky Flats facility of Rockwell, some of the wastes are contaminated with plutonium. An incinerator for the combustible portion of these wastes was installed in 1959. It is still operating, although modifications have been made several times, particularly to the off-gas cleanup train.

Pretreatment of Wastes. Combustible contaminated wastes are sorted at the generating sitp and placed into 242- 1 drums, each lined with a polyethylene bag. When the drum is about threequarters full, the bag is sealed. The drums are transported to the assay area where the plutonium in each is determined by gamma-neutron-counting 
techniques. If a drum contains $>0.0008 \mathrm{~g}$ of plutonium per gram of combustible material, it is sent to the incineration facility; if it contains less plutonium, it is sent for burial. The discard limit soon may drop to $0.0004 \mathrm{~g}$ of plutonium per gram of combustible material.

At the incinerator site, the drum lids are removed and the polyethylene bag is placed in the incinerator glove box. The bag is opened, and the contents are again sorted to remove noncombustible or potentially explosive materials. The combustible wastes consist of rags, paper, wood, process filters, plastics, etc. Approximately $30 \mathrm{wt}^{\mathrm{c}} \mathrm{c}$. of the waste currently incinerated is PVC. Some sludges are also fed to the incinerator in order to dry them.

Loading. The incinerator is loaded with a small amount of dry paper; the off-gas cleanup train is started; and the paper is ignited with a match. More dry waste is added by hand through the furnace door until a good fire is going.

The feeding rate is then determined by the temperature in the furnace; when the temperature begins to fall, a new batch is fed in. About $15.9 \mathrm{~kg} / \mathrm{h}$ $(35 \mathrm{lb} / \mathrm{h})$ can be charged at the rate of $0.9-227 \mathrm{~kg}$ at a time.

The incinerator is run until an estimated $1.5 \mathrm{~kg}$ of plutonium has been loaded. The ash pit is then cleaned out before more trash is burned.

Incinerator Design. The incinerator (Fig. 45) has not been altered appreciably since its installation in 1959. It consists of a primary and secondary combustion chamber, each lined with firebrick 15.24 $\mathrm{cm}$ thick. The firebox shell is constructed of stainless steel. A grate (Fig. 45) is located in the lower half of the primary chamber. Supplementary oxygen is used in both combustion chambers to maintain operating temperatures at $1200-1400^{\circ} \mathrm{C}$. The gases exit the secondary chamber at $\sim 750^{\circ} \mathrm{C}$. The interior of the incinerator is maintained at a pressure of $-249 \mathrm{~Pa}(-1$ in. water gauge). The firebox is completely enclosed in a stainless-steel glove box. Combustion air (overfire and underfire) is drawn from the glove-box enclosure.

Off-Gas Cleanup. The gases from the secondary combustion chamber exit into the cleanup train. The train has undergone several modifications over the years. In 1.959 a completely dry system was installed and was used for $\sim 8 \mathrm{yr}$. Its sequence was (1) air-to-air heat exchanger, (2) air-to-air heat $2 x-$ changer, (3) slag-wool filter, (4) air-to-air heai exchanger, (5) tar pot, (6) filter plenum (4 banks of 12 absolute filters), and (7) induced-draft fan.

Hot air from the first heat exchanger was added after the tar pot to increase the temperature of the

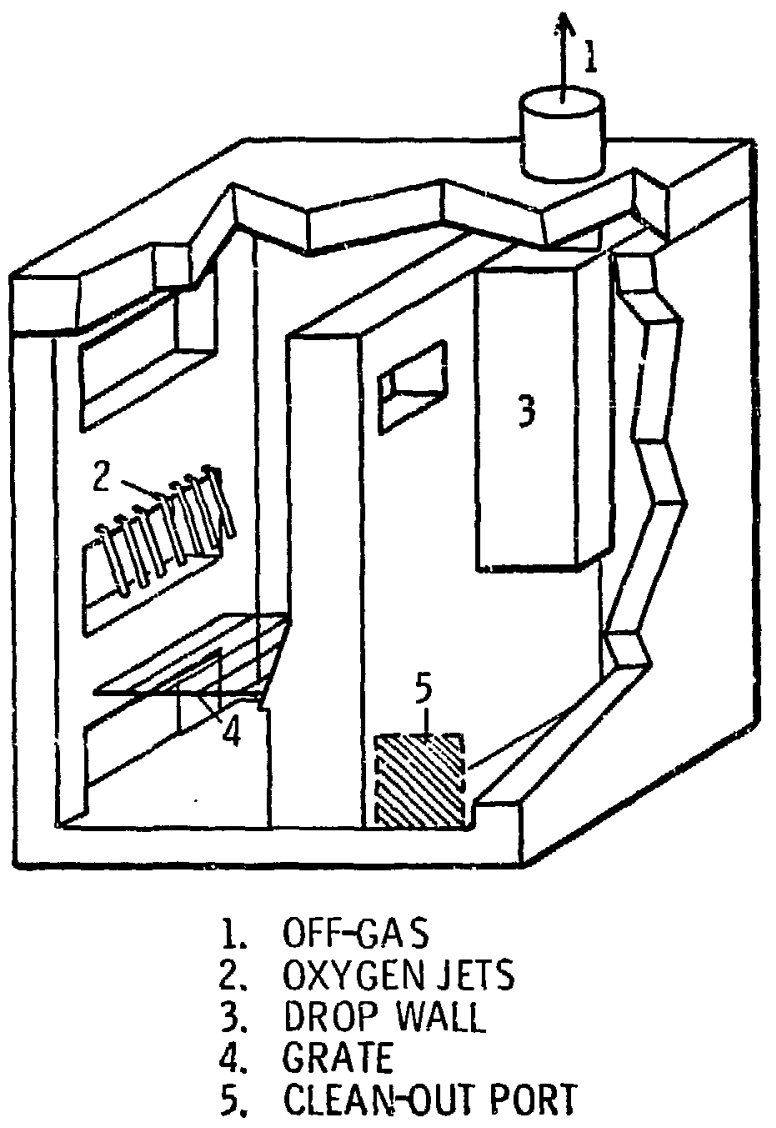

Fig. 45.

Plutonium-recovery incinerator at Rockwell International, Rocky Flats, CO.

gases and avoid condensation in the absolute filters. The gases, after passing through the induced-draft fan, exited to the main plenum.

In the late 1960's the first modification was made to the off-gas train. The slag-wool filter was replaced by a cyclone. Then a system was installed to spray a fine mist of water across the face of the first bank of absolute filters.

Late in 1967, the last (No. 3) heat exchanger was removed and replaced by a water-cooled exchanger, a caustic venturi scrubber, and a wet cyclone and mist eliminator. The mist spray across the first bank of absolute filters also was removed.

In 1968 the water-cooled heat exchanger was replaced by a stainless-steel spray chamber.

The dry cyclone was recently removed from the system because it had deteriorated and had never been very effective.

The present cleanup system, then, consists of (1) a No. 1 air-to-air heat exchanger (inlet 800 - 
$700^{\circ} \mathrm{C}$ ), (2) a No. 2 air-to-air heat exchanger (inlet $600-700^{\circ} \mathrm{C}$ ), (3) a caustic-spray cooler (inlet $300^{\circ} \mathrm{C}$ ), (4) a wet venturi scrubber, (5) a wet cyclone, (6) a mist eliminator, (7) an induced-draft fan, (8) a filter plenum, and (9) an induced-draft fan.

The liquor from the scrubber system is filtered, cooled, sent to a delay tank and recirculated $(\mathrm{KOH}$ is added to the solution to maintain about $1 M$ $\mathrm{KOH})$. About $30-50 / \mathrm{h}$ of liquor are continuously bled from the system. This blowdown liquor is routed to the liquid-waste treatment facility. The rotary drum filter is treated with a "precoat." At regular intervals this precoat, which contains plutonium and other insoluble compounds filtered from the liquor is shaved off. This residue is then discarded.

Ash Removal. As the material in the primary combustion chamber burns on the grate, the ash drops through. The hot ashes are raked out with a long-hanáled rake into a cooling area. Once cool, they are run through a small ball-mill and sent for plutonium recovery.

The waste is not completely burned; the ash is $\sim 30 \mathrm{wt} \%$ carbon and $40 \mathrm{wt} \% \mathrm{SiO}_{2}$. The large amount of carbon causes filtering problems during plutonium recovery. Material-balance data indicate that $\sim 99 \%$ of the plutonium in the combustibles ends up in the ash.

About once every six months the facility is shut down and completely cleaned.

Performance. The incinerator has been operating since 1959, except for short downtimes for modification. It is currently in operation $\sim 40^{\circ} \%$ of the time. In September 1972, 83 drums of waste were incinerated. During that time, 9 one-quarter-full drums of ash were produced, 15 drums of caustic went to liquid-waste treatment for volume reduction and treatment, and 20 drums of used filters were shipped out. Therefore, during that September, the volume reduction was $\sim 65 \%$.

The main expense in plutonium recovery is the cost of leaching. Incineration accounts for only $\sim 22 \%$ of the cost of plutonium recovery.

Problems. During the early years, when only a dry off-gas cleanup train was operating, PVC was not incinerated because there was no way to remove the resulting $\mathrm{HCl}$ from the off-gases. The dry system had other disadvantages. Channeling caused inadequacies in the slag-wool filter bed and soot particles were able to pass through and deposit on the plenum filters. When a layer of soot had built up on the filters, they would catch fire when a small, still- smoldering particle impinged on the filter. (These fires were extinguished with water.)

To overcome these problems, the dry cyclone was installed to replace the slag-wool filter, and a wet spray was used on the face of the first bank of absolute filters. However, the spray nozzles occasionally plugged and filter fires would occur again. Also, replacement of filters continued to be a problem; the first bank of 12 absolute filters had to be replaced about twice a week.

The last air-to-air heat exchanger was replaced by a water-cooled exchanger; a venturi, cyclone, and demister were installed; and the filter sprays were removed. These modifications eliminated the filter fires and PVC could now be charged. However, the water-cooled heat exchanger soon became plugged. After caustic-cleaning, the facility was again placed in operation. After a short time the titanium cooling coil corroded and ruptured; in fact, all the coils were badly corroded. Therefore, this heat exchanger was replaced by a stainless-steel spray chamber.

Corrosion in the spray chamber is reduced by using $1.5 \mathrm{M} \mathrm{KOH}$ liquid for the spray. But salting occurs as the solution flashes, and salts build up opposite the spray-chamber inlet duct. To prevent excessive buildup, $\sim 189$ / of hot water must be flushed through the spray nozzl after each run, and about once a week the chamber must be flushed with a hose.

The Inconel, No. 1 air-to-air heat exchanger must be replaced about every 18 months. If stainless steel is used, replacement is necessary within 6-8 months. The main trouble here is caused by condensables which plug and foul the heat exchangers. Condensable residues are either wet soot or tar deposits which absorb condensed acids and become very corrosive.

The introduction of the wet system increased the lifetimes of the absolute filters, so that at present the filters need to be changed only about once every 2 wk.

Several changes have been made to increase the lifetime of the furnace lining. For example, the firebrick is now heated to $\sim 2000^{\circ} \mathrm{C}$ before it is installed because incinerator temperatures are not high enough to cure the brick and it used to crumble prematurely. In addition, the operating temperature of the furnace has been reduced so that gases now exit at $800-770^{\circ} \mathrm{C}$ rather than $900^{\circ} \mathrm{C}$. With these changes, rebricking is now necessary only every $2 \mathrm{yr}$.

Auxiliary natural-gas burners were used previously in the primary and secondary chambers. However, there was an explnsion, which may have been caused by flameout of at least one burner. Since that time, only suppiemental oxygen and 
careful control of feeding have been used to maintain proper operating temperatures.

\section{SOURCES}

R. Dennis and L. Silverman, "Rudioactive Waste Incinerator Design and Operational Experience - A Review," in Proc. Seventh AEC Air Cleaning Conf., Oct. 10-12, 1961, held at Brookhaven National Laboratory, AEC report TID-7627 (March 1962), pp. 422-423.

R. S. Foster, "Incineration of Plutonium Conteminated Waste Materials. A Preliminary Study for Replacement of the Existing Rocky Flats Incinerator," Dow Rocky Flats report RFP-735 (May 1966).

R. D. Gaskins and W. G. Kazel, "Off-Gas Systems for Nuclear Contuminated Combustibles," in Proc. Tenth AEC Air Cleaning Conf. Hrld in New York, NY, August 28, 1968, AEC report CONF-680821 (December 1968): pp. 312-329.

Office memorandum of an on-site visit to Dow Chemical by R. Brasier, LASL (August 1972).

R. Southworth, Rockwell International, Rocky Flats, personal communication.

C. Tesitor, Rockwell International, Rocky Flats, written and personal communications.

B. Owen, Rockwell International, Rocky Flats, staff communication.

b. New Incinerators for LSA and HSA Wastes. Two new incinerators will be installed in the plutonium-recovery facility under construction et the Rockwell Rocky Flats plant. One incinerator will burn high-level solid wastes (those containing $>3 \mathrm{x}$ $10^{-3} \mathrm{mg}$ of plutonium per gram of waste) and liquid wastes, whereas the other incinerator will burn lowlevel solid wastes (containing $<3 \times 10^{-3} \mathrm{mg}$ of plutonium per gram of waste).

The two incinerators will be near each other in a canyon, but separated by a wall. It will be possible to operate the incinerators from outside the canyon through the use of remotely operated valves and mechanical devices. Any major maintenance will require entry into the canyon, and pres, ure suits will be required for maintenance personnel.
Pretreatment of Wastes. Before reaching the incinerator, all wastes will have been assayed for plutonium content and segregated irto high-level and low-level solid waste. The waste from other generating sites at the plant will be packaged in 242-f drums and transferred to the incinerator. (HEPA filters will be transported in cardboard boxes.) Wastes generated in the recovery building will be transferred to the incinerator area by a retriever system and a pneumatic conveyor, as well as by external transfer in a drum to the glove-box system.

The drummed and boxed waste will be introduced into the proper feed preparation area by an air-lock glove box with guillotine-type doors. Once the waste is in the feed preparation areas the drums and boxes will be opened manually and the individual packages will be placed in the feeder.

The feed to the LSA incinerator will consist of solid wastes. Table VIII shows the expected composition of the LSA feed. In addition to solid wastes, the HSA incinerator will handle liquid wastes. The expected composition of these wastes is given in Tables IX and $\mathrm{X}$.

LSA Incinerator Loading. The LSA incinerator will burn $\sim 68.1 \mathrm{~kg} / \mathrm{h}$ (150 lb) of solid waste. The waste will be fed through a double-doored ramfeeder arrangement in batches of about $2.27 \mathrm{~kg}(5 \mathrm{lb})$ of waste every 2 min for $\sim 5 \mathrm{~h}$. Then charging will be discontinued but, so that rasidual combustibles will be burned, the incinerator will be maintained at operating temperature for $\sim 1$ hr by a diesel-fuel burner.

LSA Incinerator Design. The design of the LSA incinerator is shown in Fig. 46. It has a cylindrical primary combustion chamber $2.64 \mathrm{~m}$ in diameter and $\sim 4.57 \mathrm{~m}$ high and a refractory-lined afterburner.

TABLE VII

COMPOSITION OF LiA INCINERATOR FEED

(\%)

Rubber $\quad 25.0$

Paper $\quad 46.5$

FVC 1.0

Cloth $\quad 6.0$

Leather 0.5

Wood $\quad \mathbf{7 . 0}$

Water $\quad 5.0$

Tramp metal $\quad 5.0$ 
TABLE IX

\section{COMPOSITION OF SOLID FEED \\ TO HSA INCINERATOR}

\begin{tabular}{|c|c|c|}
\hline \multicolumn{2}{|c|}{$\begin{array}{c}\text { Mixed Waste } \\
\text { Regularly Bumed }\end{array}$} & \multirow{2}{*}{$\begin{array}{c}\text { Waste } \\
\text { Campaigned Through } \\
\text { Leaded dry box gioves }\end{array}$} \\
\hline PVC & $50 \%$ & \\
\hline Polyethylene & $12 \%$ & HEPA filters \\
\hline Polypropylene & $2 \%$ & Graphite \\
\hline Paper & $26 \%$ & \\
\hline
\end{tabular}

TABLE $X$

\section{COMPOSITLON OF LIQUID FEED TO HSA INCINERATOR}

(\%)

$\begin{array}{lr}\text { Carbon tetrachloride } & 32.6 \\ \text { Trichloroethane } & 36.1 \\ \text { Cutting oil } & 12.9 \\ \text { Laboratory wastes } & 2.7 \\ \text { lon exchange resin } & 7.1 \\ \text { Warer } & 8.6\end{array}$

The primary chamber will be of $1.27 \cdot \mathrm{cm}$ steel plate lined with $11.4 \mathrm{~cm}$ of Insul refractory and $11.4 \mathrm{~cm}$ of $\mathrm{Al}_{2} \mathrm{O}_{3}$ refractory. The primary combustion chaniber and the afterburner will use auxiliary diesel-fuel burners to maintain the proper operating temperature. The primary combustion chamber will operate at $\sim 800^{\circ} \mathrm{C}$ and the afterburner at $\sim 1000^{\circ} \mathrm{C}$. Minimum shell temperaiures of $150^{\circ} \mathrm{C}$ are expected.

A grate will be on the bottom of the primary combustion chamber, and combustion air will enter above the grate. A rabble arm moving at 0.5-2.5 rpm will mix the burning waste. The rabble arms will be air-cooled and constructed of refractory-cuvered stainless steel.

LSA Off-Gas Cleanup. The off-gases will pass from the afterburner through a brick-lined duct into two scrubbing units in series. Each scrubbing unit will consist of a wetted throat venturi scrubber (pressure drop $9960 \mathrm{~Pa}$, or 40 in. water gauge) followed by a gas-liquid separator. A caustic solution $(\mathrm{KOH})$ will be used in each unit. Each venturi will be made of Hastelloy $B$, and each separator will be made of fiber glass.

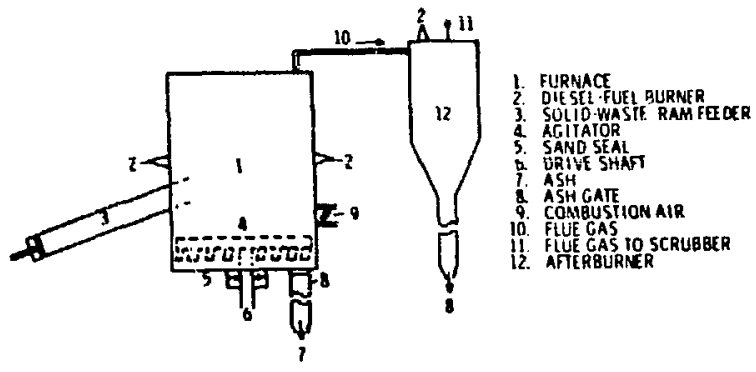

Fig. $4 \mathrm{a}$.

LSA incinerator at Rockuell International, Rocky Flats, CO.

The liquid from the scrubher units will be cooled, and $\mathrm{KOH}$ added. Some of the liquid will be circulated back to the system. A bleed -off stream will be routed to waste recovery. Fresh malse-up water will serve as a hack wash in the separator vessels.

If there should be excessive pressure or temperature in the primary scrubber, the hot flue gas will be diverted to the back-up scrubbing system, consisting of an alternate venturi which discharges to the secondary scrubber column. Waste loading will be suspended until the primary scrubber returns to service.

The gases from the last separator vessel will discharge through an induced-draft fan into the main exhaust plenum, which will consist of four stages of HEPA filters. Included in the gases flowing through the filters will be the air from the canyon and the cleaned off-gases from the HSA system.

LSA Ash Removal. While the waste is undergoing combustion in the primary combustion chamber. the ash remains in the chamber. When the burnout cycle has been completed, the ash-discharge slide gate will be opened. The ash raked out by the rotation of the rabble arm will discharge into the conveyor-cooler.

The afterburner also has a set of slide gatas to permit discharge of ash that may be produced in the afterburnes. The ash from the conveyor-cooler and slide gate-afterburner system finally discharges into a drum. The ash in this drum will then be gammascanned to determine its approximate plutonium content. A more accurate value for plutonium will be obtained later to provide a material balance for the system. In gencral, ash from the LSA incinerator will not contain enough plutonium to warrant sending the ash for recovery. 
LSA Sajety. Among the many safety features installed in the system are a sprinkler system in the glove box, availability of inert gas for the ram-feeder system, detection equipment for flameout, remotely operated cameras, temperature inúicators, and gravity overflow systems. A detailed disclission of these safeties can be found in the source material.

HSA Incinerator Loading. The HSA solid wastes will be fed to the primary combustion chamber through a double-doored ram feeder. A burner located above the auriliary diesel-fuel burner will atomize and burn the liquid wastes. This arrangement is shown in Fig. 47. The incinerator is sized to burn $\sim 40.9 \mathrm{~kg} / \mathrm{h}$ of mixed solid waste of the composition shown in Table IX. The HEPA filters and the rubber gloves will have to be campaigned through the incinerator because these materials must be burned at a temperature $<700^{\circ} \mathrm{C}$ to prevent slagging. The graphite will be ground and burned at $1000^{\circ} \mathrm{C}$. Liquid wastes and used resin will be campaigned through the incinerator separately or burned at a reduced rate with the mixed solicl waste.

The inventory limit on the permissible amount of plutonium in the system is controlled by the feed rate, the limit of $1 \mathrm{~kg}$ of plutonium per dirum, and the slope and rotation rate of the incinerator. The use of these controls will keep the kiln operation well below any mass criticality limits.

ISA Incinerator Design. The main combustion chamber, shown in Fig. 47, will be a rotary kiln. One reason for the choice if this type of unit is that it provides for automatic, continuouis removal of ash. The kiln will be $1.83 \mathrm{~m}$ in internal diameter and 4.57 m long. As shown in Fig. 47, the waste, some of the suppiemental fuel, and the air for combustion $\left\{\sim 156^{\circ} i\right.$ excess $\left.O_{2}\right)$ will enter from one end of the unit.

Residence time of the waste in the kiln will be $\sim 1 \mathrm{~h}$ with a minimal rotation rate of 1-2 $\mathrm{rpm}$. Steam
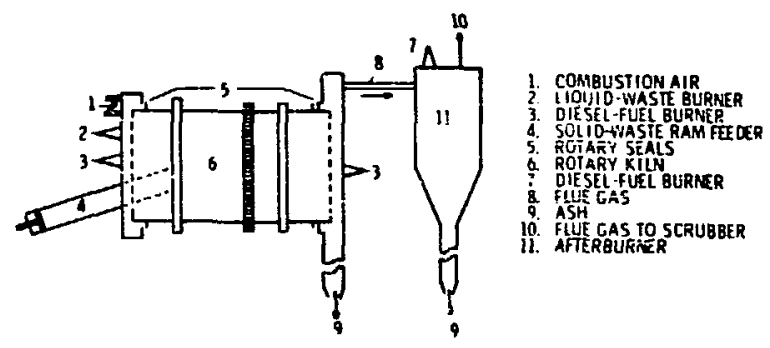

Fig. 47.

HSA incinerator at Rockwell International, Rncky Flats, CO. injection can be used to control the fleme geometry. The kiln liner will be a $11.4-\mathrm{cm}(4.5$-in.)-thick refractory (Corundel D) backed by $11.4 \mathrm{~cm}$ of Diatherm 23. The shell will be $1.9-\mathrm{cm}$ steel. A surface temperature of $\sim 149^{\circ} \mathrm{C}$ is expected and should prevent condensation of acid gases. Seals for the kiln are to be spring-loaded flanges with asbestos gaskets. The seals will operate at about $25 \mathrm{~Pa}(0.1$ in. water gauge) differential.

After the initi"l burning in the rotary kiln, further oxidation will occur in a refractory-lined efterburner which will be equipped with an auxiliary diesel-fuel burner and will operate at $\sim 1000^{\circ} \mathrm{C}$.

HSA Off-Gas Cleanup. The gases will exit the afterburner into a brick-lined duct that connec ts with a scrubber systen similar in design to that used on the LSA system. However, multiple, parallel venturis will be used to limit any void to $<15.24-\mathrm{cr}$ diam or a slab $<5.08 \mathrm{~cm}$ thick. Borosilicate Raschig rings (Fig. 48) wil! be used in the first separator
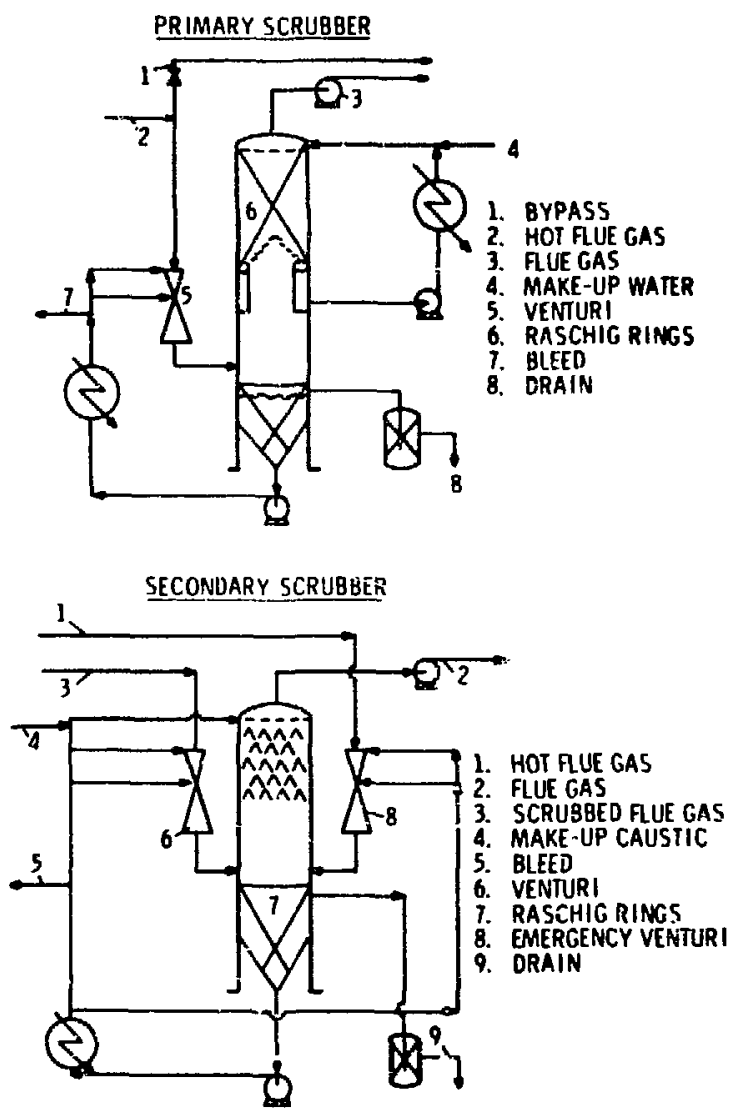

Fig. 48.

Scrubbers in the HSA incinerator. 
vessel. Only water will be used in this first scruiber unit; howeve:, the scrubber liquor will actually be a dilute solution of $\mathrm{HC}$ ! because of absorption of the $\mathrm{HCl}$ produced during burning of $\mathrm{Cl}$--containing compounds. After passing through tlie first scrubber unit the gas wili enter the second scrubber unit (Fig. 48). Here $\mathrm{KOH}$ aill be adiad to the solution.

A back-up venturi system, as shown in Fig. 48 , has been provided in case of primary-scrubber malfunction. Gases from the off-gas cleanup train will pass through an induced-draft fan into the mair: exhaust plenum already described for the LSA system.

Heat exchangers in the liquid system will cool the liquid, some of which will be bled off and sent to the waste-recovery facility. In both LSA and HSA scrubber systems, the liquor will probably undergo some type of filtration to remove insolubles.

HSA Ash Removal. The ash will travel slowly down the kiln and will discharge from the end through a slide-gate arrangement.

All ash from the FSA system, all other slurry residue, etc., will be assayed so that a complete plutonium material balance can be maintained. Ash from the HSA incinerator will contain $-5 \mathrm{wt} \%$ plutonium and will be sent for plutonium recovery.

HSA Safety. The safety interlocks, monitors, and devices are similar to those of the LSA system. An auxiliary jet-ejector system is provided for both systems in case of power failure. More details on the safety of the HSA incinerator system are available in the source material.

\section{SOURCES}

D. Ziegler, Rockwell International, Rocky Flats, personal communication.

"New Plutonium Recovery Facility Incinerator Study," C. F. Braun and Co., Project 4410-P, July 28, 1972.

j. Warnes, LASL, memorandum.

C. F. Braun and Co. drawing numbers 25151-003, 25151-006, 25151-008, and 25151-106.

M. E. McLain, Notes on meeting at C. F. Braun and Co., Alhambra, CA, September 10, 1973.

D. L. Ziegler, "Incineration Process Fire and Explo. sion Protection," in Proc. Thirteenth AFC Air
Cleaning Conf., San Francisco, 12-15 August 1974. ÁEC report CONF-740807.

\section{Atlantic Kichfield Hanford Co. (ARHCO),} Richland, WA

Incinerator for Plutonium Recovery. A Contaminated Waste Recovery Facility, which includes both incineration and leaching equipment, was built at Hanford in 1961 to recover plutonium from waste materials. The incinergtor has not been oferating for some time, but may start up again in the summer of 1976.

Pretreatment of Wastes. The wastes are placed in cartons at the generatiur: sites. Cartons containing $>2 \mathrm{~g}$ of piutonium are takt $\mathrm{n}$ to the Recovery Facility, where each carton is introduced into the sorting hood through an air lock and sorted manually. Leachables are placed in the leach pots; combustibles are sent to the incinerator area. The scrap accepted for incineration in the past consisted of PVC, rags, and paper (cartons and towels).

Incinerator feed is chopped in a rotating drum which has blades set in its periphery parallel to the axis.

Loading. From the chopper, the wastes move by a feed conveyor onto the incinerator's conveyor belt which goes though the primary combustion chamber. This arrangement of sorting hood, leaching, and incinerator areas is shown in Fig. 49.

Incinerator Design. The incinerator has two combustion chambers connected by flue tubes. The primary combustion chamber is a 3-m-long semicylinder with a flat bottom. Along the bottom of this chamber a moving belt is used to carry the wastes through the incinerator. The primary chamber is maintained at $700-800^{\circ} \mathrm{C}$ by resistanceheating elements.

The primary chamber is connected to the secondary chamber by four flue risers. (Off-gases from the primary chamber undergo further oxjdation here.) Air is added to both the primary and secondary chambers. The arrange:nent of this unit is shown in Fig. 49.

The furnace is shielded by $45 \mathrm{~cm}$ of firebrick insulation. The whole unit is contained in a stainlesssteel glove hox.

The optimum throughput of the incinerator is $113.3-198.2$ f of $100-\mathrm{g} / \mathrm{f}$-density waste per 8 -h period. 


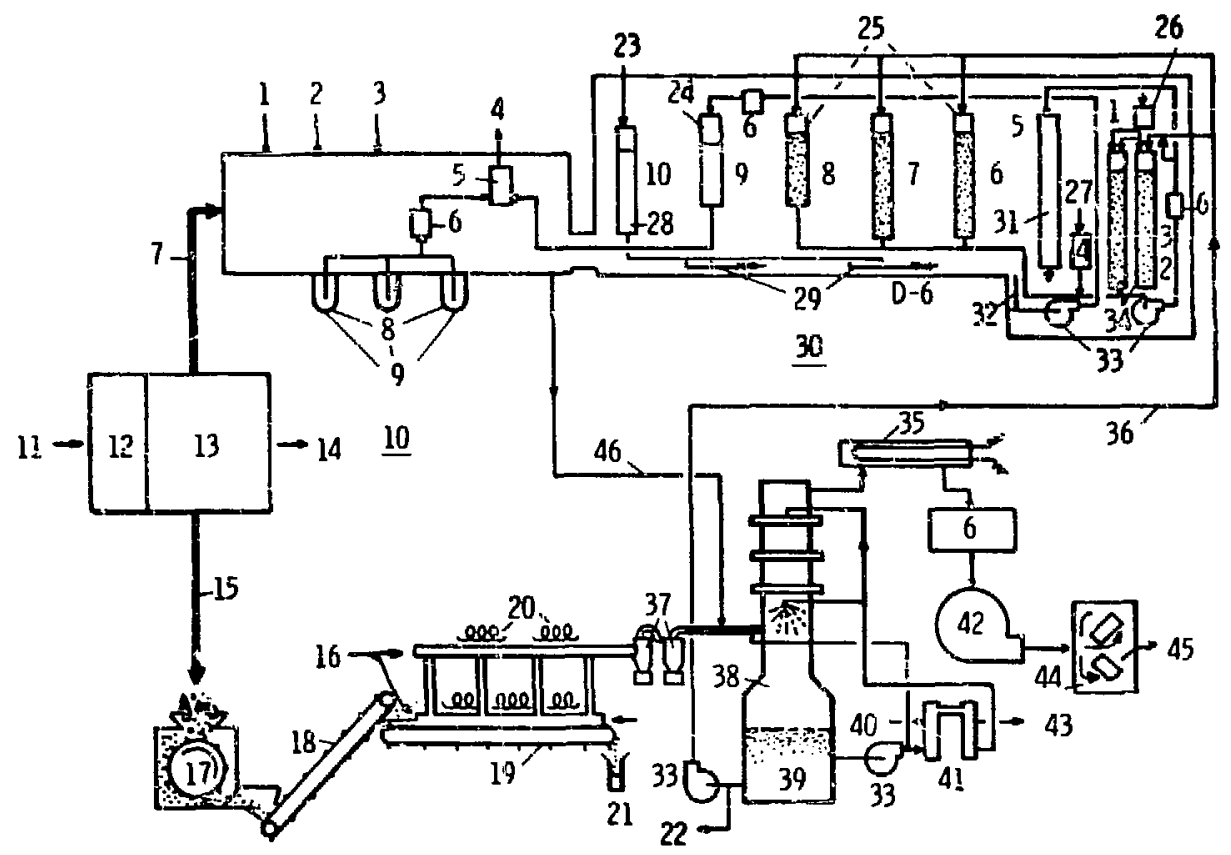

1. MISC. CHEMICALS

24. PRODUCT TANK

2. $\mathrm{HNO}_{3}$

3. $\mathrm{H}_{2} \mathrm{O}$

4. LOAD OUT FOR PU SOLUTIONS

5. TRANSFER HEÁU TANK

6. FILTER

7. NON COMBUSTIBLES

8. STEAM

9. LFACH POTS

10. LEACH HOOD 1

11. PACKAGED MISC. PU WASTIE RAGS, GLOVES, PAPER, PLASTIC

12. AIR LOCK

13. SORTING HOOD

14. WASTE FOR BURIAL

i5. COAFBUSTIBLES

16. AIR

17. CHOPPER

18. CONVEYOR

19. INCINERATOP

20. HEATING ELEMENTS

21. ASH

22. WASTE D-6

23. $\mathrm{H}_{2} \mathrm{O} \mathrm{HNO}_{3}$

25. STORAGE TANKS

26. CHEMICAL ADD

27. FILTER AIO

28. CHEMICAL TANK

29. LEACH PANS

30. LEACH HOOD 2

31. WASIE TANK

32. COLLECTION TANK

33. PUMP

34. TREATMENT TANKS

35. HEATER

36. SCRUBBER SOLUTION FOR TREATMENT

37. CYCLONES

38. $\mathrm{H}_{2} \mathrm{NaOH}$ UREA

39. OFF-GAS SCRUBBER

40. COOLING $\mathrm{H}_{2} \mathrm{O}$

41. HEAT EXCHANGE?

4Zे. BLOWER

43. DRAIN

44. FILTER BOX

45. EXHAUST SYSTEM

46. LEACH HOOD EXHAUST

Fig. 49.

Plutoniurn-recovery incinerator at ARHCO. 
Off-(ias Cieanup. Q'ses from the secondary combustion chamber first pass through two loripressidre-drop cyclones, whene largi: pieces of particulate are removed. Next, the gas stream discharges along with leach-hood exha "it into a $2.7-\mathrm{m}$ iall scrubber containing a quench-sprky section, two impingernent baffles, and a high-velocity bafleplate stage. The vessel is const ructed of 316 stainless steel. Approximately 90\% of all paticies $>\mathbf{n . 2 7 - \mu}$ dian, are remsved in the scribber. The guses are then seheated by an efectric heater and passed through a filtet und indured-crait fan, and then thrcugh two more high-efficiency filters in series befure being discharged to the main-building stack (see Fig. 49).

The scrubber liquor is a solution of water. $\mathrm{NaOH}$. ard urea. and is cooled in a water-cooled heat exchtingter bofore being recirculated to the system. Hlowdosit from the system is sert to vaste trat. ment.

Ash Armotal. The als from the incinerator is carricd out of the primary sombastion chasuber on the conveyo belt and drops into a hipper. From the hopper. it it dischaspest inke an ash-charaing head. where it and ash from the cyclone hopper are pest in containers fin transportation to the plistonitom. secovery facility.

Prrbluna. This aRHCO facility has hed revera! problems and has been out of uneration more than it hus been it, operation. Initially. the incinerator was a une-piece unit. Holded from snetinas of east, highietnperature, high nickel alloy sted. Massive tracturts atused by thermal cycing oceurted after 1 yr and asere repaired. Twenty-tro munth later, the inciveratur failed atgin, and was redesizned to reduce thernas stress. The new unit tan for 9 momthe until stress-curnoiton cracking occuered and repair was adnin ncessary. Hith temperatures apparen!ly bast. increared thermal strex and fotmation of reftactory $\mathrm{PuO}_{\text {; }}$; consequenty. the unit has hech restritted to

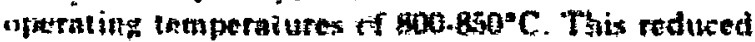
temserature and an izardequats air supply have rosulted in inconflete combutsion of the waste.

Duting earis nperation. the conseyot belt throush the furnact fregtemely broke. Eventually a bett wus drseloped that will lest -6 months. INeplacenent requires $\rightarrow$ ih.,

Air dist tibutiun alos has bees $\mathrm{g}$ problem. In addii. tim to the variabilisy of the air suply. Thaterini piles up on the bell and sometimes air flos thrugh the partially burned material is not optimum. A new distributien systetn has been fabticaled but has not vit boen used hecause the facility was shut down before the system was ready. "This system shuld im. prove air distribution and thus cumbustion.

Plugging, partly the result of incomvlete combus. tion, has ocrurred in verious areas. The first (wo) risers between the primary and secondary chambers muse be "roto-gooted" every $2-4$ months. Also, bends in the off-gas system and areas of liquid-gas interface can plug up, and back-washing of these zrens is necessary. Lead from gloves and chlusite from chlorine compouncis fed to the incineratuz can form $\mathrm{PbCl}_{2}$ which can condense in the cooler off-gals lines and cause plugging. Therefore, lest gloves are nuw leached and not burned. The first absuiute filter downstrean from the scrubber must be chunged every $2-3$ wh.

it is difficuit is seal a furnace through which a cunveyor belt moven, and the diy box must provide the barrier against migration of plutosium ints the operating area. During scrubber-sepnir. temporar: containment bisriers of shget plastic ment be put andind the equipmest to linit the sprent of contemination, and repaimen must sest complete protective suits.

Fire has bee snother problem. Stith the noving. grate-type furnase. Nashback may acour. Hanford hus experienced weveral fires in the frout end area uf the fumace. A wire seren. placed in the feed end of the incinerotst and nitrogen atded at the primary combustion ctuamber inlet have helped prevent Nashback. In widition. water sprays are installed in the giove-box working areas, and glove ports near the incinerator ane protacted wisth beat shieids at all times duristin incineration.

Scribioer lises cheationally have to he replaced becasst the contamitated scrubber station itas lsaked through the lines.

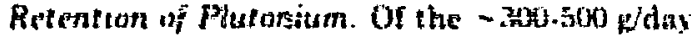
of plutoniug conterised in the waste fed to the in. cinerator. $-95.97 \%$ remain in the ash. and mast of the remeinder is removed in the scrubber.

\section{SOURCES}

L. M. Iinights, "Continuous Incineretion of Plutnniun -Hearitse Scrap," Atlantic Richíeld Han. ford teport ARA-S.

O. F. Hill C. D. Corbit. E. F. Vithand, and R. H. Wilstm, "Inadionetive Solid Wuse Manapement at Fichland." Atlantic Richfield Haniurd repert Alth. 1:596 (February 1970). 
R. L. Bragr and F. D. Fisher, "Recovery of Plutorium from 7PPR Unmeasurable Wastes, I : y 27. 1967 - Jamuary 27, 1968," Nuclear Materials and Equipment Corp. repon NUMEC-1661.1.

Mi. Muller, ARHCO. personal communication.

A. E. Barber, Technical Information Services. AllHCO. written crmmunication.

1. Mudge, Battelle-Northwest, personal com. munication.

(i. Hey. "Incinerator and Off-Ges Scrubber Tests," General blectric. Hanfurd, repust HW-f8788 (March 19611.

\section{CONCZUBLONG}

\section{A. Problem Azeas}

There are sereral major probletn arens in the in. cineration sof ratitactive nstes. and these must he recognized if more reliable and efficient incinernt facilities are to ise thuilt. The problems fall into four categories: (1) containnent, (2) comburition, (3) materiuls. and (4) criticality control.

\section{Contuinment}

a. Leading. Waste is usually fed into the furnace throuseh a dixls, a ram-feed arrangement. or on a moving belt, or it may be shredded and blown in.

It is obvirous that manual loading through a doet can result in the escape of aases form the furnnce and is not a fond system if maximunt consainment is slesited.

In the case of ram-feeding, when the ran pushes the wate into the primary chamber. names from the furnace can cause nashback into the feeder. Plaxtice may stick to the ram and burs as the ram is withdrawn from the jurnace. Maximum containment in rom-feeding requires ( 1 ) a double-pate lock or similar arrongememt. (2) fravisy feed into the furnace as an anti-sticking measure. (a) an inert gtas-or liquid-spray system for fire suppressiom. (1) a secon. dart containment shell to house the londing system. and (i) propes insulation for the face of the feeder.

Moving-bolt londing systems cannot be ensil: sealed and flahback can be a problem.

shredided waste may be blown inta the furnnce. Any metal in the waste going to the shredder or any excessive mechanical vibration in the system can cause maintenance and containment problems.

b. Ash Removal. Containment is also a problem during ash removal. The fine, free-flowing ash can easily become airborne. Good techniques are necessary for sealing ine connection between the drum and the ush hopper. and some arrangement is required for removing the drum without producing airborne dust.

Comnaratively nontoxic ash is sometimes vacuumod by an operator wearing protective clothing. but the air discharge from the vacuum munt be filtered before release to the ambient air.

In any type of ash-disposai system. noncom. bustiblen must be removec from the waste or the ash-remova! inechanisms may jam. removal exits will be soo small. and containment wili be difficult.

r. Mressure Surge. Radionuclides can also leak durine "puffing" of the furnace. No matier how carefislly the saste is fed to the combustion chnmber. differences in heat content and feed rate. as welt as accidental inclusion of explosive materials (such as nitrocellulasel, will result in sudden pressitre surges in the combustion chamber. If there is uny pressure drop after the furnace, such as that from an off-zas cleanup train. the gases will tend ta vent througk the sides of the furnace. Unless the system is built to withstand extreme pressures. "purfing" problems must be accepted. Emergency vents can the installed and/or the furnare can be surrusnded by a secondary container or perhajw imolsted in a canyon.

d. I fi-cias Cleanup. A containment problem may also be presented by the off-gases, which contain combistion gakes, entrained particulates, arid unburned tars, and soot.

The subject af "gas clennup covers too wide an srea to lie covered completely fere, but several ma. jor problems will be inentioned.

One problem is the highly toxic acid cases often found in the oft-gases. If sulfur, chlorine, or fluoring is in the wastes, gases such as $\mathrm{SO}_{\mathrm{i}}, \mathrm{SO}, \mathrm{HCl}, \mathrm{Cl}_{2}$, or $H F$ will be produced during incineration. Linder some combustion conditions. $\mathrm{NO}_{3}$ is produced. Chemical reactions of these compounds can result in both higli. and low-temperature corrosion. One sols. thon to this problem is to omit wastes containing large amunts of sulfur, chlorine. and/or nuarine. Ant her solurion is to reinove these compounds from the gas stream. Currently, use of a scrubber having a high contact area and gused retention tiale isuch as a 
packed tower) and some type of alkaline scrub solution is the most widely practiced method for removal of some of these compounds. However, radionuclides are also removed by the scrubbcrs, and the problem of an off-gas that contains radionuclides becomes the problem of a liquor that contains radionuclides. Use of a fluid bed composed of some alkaline compound might be considered.

In many cases the cleanup train has been clogged by soot and tars. Thus, either the incinerator system must be designed to provide almost complete combustion or equipment must be provided to remove the unburned products from the gas steam.

Various methods have been tried to rexiove tars and soot from the off-gas. Jome experience with sintered metal filters at Korky Flats indicates that these will work if only soot is present; heavy tars deposited on the filters cannot be blown back for cleaning. As described earlier, different iypes of candles are being used, particularly in Europe and Japan. Cernmic candles have a limited lifetime; the asbestos in asbestos-filied metal candles inust be replaced from time to time; gno metal randles are subject to corrosion.

Further development work on the removal of tars and soot from the cleanup train and the attainment of complete combustion would be helpiul.

It must be recognized that the same ciesign prirsciples applied to the design of other industrial offpas cleanup systems musi be also applied to in. cinerator systems. More data on changes in flow rates and somposition of incinerator off-zases would be helpful to the design engineer. Until such data are available. "worst pussible" coilditions will have to be the criteria for incinerator design.

Removal of anv contaminant from. a gas strear. becomes ever more difficult as the concentration of the contaminant decreases, hence the removal of low

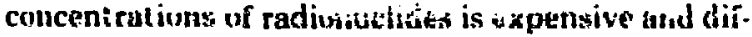
ficult.

For information on problems involving particular types of collectors. design data. etc. : he reader is referred to the sources listed and to the general liternture on the design of off-gas cleanup systems.

e. Fires and Explosions. In containment of radionuclides there always is the protslem of fires and explosions. Flashback in the loading system is possible: explosive materials may be included inadvertently in wastes: soot and tars may build up on filters and catch fire. There may also be flameout of the auxiliary fuel burner and unburned fuel may be discharged and explode. Because if is impossible in a rloced system for the operator to smell mercaptans added in gas, some designers of radioactive-wagte incinerators have decidec against the use of gas-fired burners, especially if toxic radionuclide: such as plutonium are to be present in the waste.

f. Power Luss. A final consideration in designing for containment is the possibility of power loss. If the incinerator has no off-gas cleanup train. the natural draft of the stack should remove the off-gases from the incinerator. However. when off-gas cleanup trains are used, some provision must be made for escape of the gases in the event of a power failure.

g. Maintenance. Radionuclides must somehow be contained during periods of incinerator maintenance. Entry ports and modular construction rust be desiuned into the system if contamination problems during maintenance are to be minimized. In addition, proper selection of equipinent. proper design of piping. and selection of proper const ruction materials should reciuce maintenance requirements. Maintenance problems and materials selection alsw, depend on the type of wastes to be incinerated. Corrosion-resistant components must be chusen carefully if the was'es contain constituents. such as PVC, that produce acid gases upon combustion.

\section{Combuetion}

a. Requirements for Combustion. Complete combustion is a major problem in any kind of waste in. rineration. However, the same basic requirements for combustion-time, temperature, turbulence, and oxygen supply - apply, no matter what the nature of the fuel. Because combustion is a chemiral reaction process, an understanding of combustion must include an understanding of the chemical reactions taking piace.

In any chemical reaction it takts time for the reac. tion to occur. In incineration most of the axidation usually occurs in the gases evolved from the waste. Thus. time must be allowed for an oxygen molecis:e to bump into and (if the energy is sufficient) react with a molecule of $\mathrm{CO}, \mathrm{H}_{2}, \mathrm{CH}_{4}$, etc.

As the temperature of the gaseous mixture in. creases. the numier of collisions per unit time must also increase, and the energy involved per collision incroases. Thus the probability of a chemical reaction increases rapidly with temperature increase. Assuming an activation energy of $50 \mathrm{kcal}$ and using the equation, $K a e^{-(F / k T)}$, where $K=$ the reaction rate, $\mathrm{E}=$ energy of activation. $\mathrm{T}=$ absolute tempersture. and $R=$ gas constant, it can be calculated that for a given concentration of the reac. tants the reaction rate derreases by a factor of 5000 when the temperature is lowered from $1500-1000^{\circ} \mathrm{K}$ and by a factor of $10^{11}$ when it is lowered from 100. $500^{\circ} \mathrm{K}$. 
The oxygen molecules must be well mixed with the fuel gases for a collision, hence a reaction, to occur. Good mixing (turbulence) and an adequate supply of oxygen are obviously necessary requirements for oxidation.

A complete discussion of dissociation, carbon oxidation, oxidation in the bed vs volatilization, reactions on the walls, heat loss, water as a catalyst. flame propogation, and thermodynamic data will not be included here, but can be found in the source material.

b. Combustion of Radioactive Wastes. Coniplete combustion of solid radioactive wastes is difficult because most wastes have a fairly high carbon-to. hydrogen ratio: may contain water. which requires heat input for its yaporization; and vary widely in their heat content per unit of feed. Good fuel-oxygen mixing with waste is hard to achieve, and the volatized off-gas liydrocarbons can "crack" to form heavier hydrocarbons with a higher carbon-tohydrogen ratio.

Incomplete combustion leads to several problems in radioactive-waste incineration. Tle production of sont and heavy tars can clog off-gas cleanup trains and result in a fire. Melting plastic clogs air linew and grates. Also, when combustion is incomplcte. a great cleal of carbon is left in the residue. hence the volume and weight reduction of the process are less than they could be and the material is rot completcly inert. Moreover, sarbon in the ash can cause fnaming and filtration problems during radionuclide recuiery.

When cornbustion temperatures are high (as is necessary if complete combustion is to accur quickly). the plutonium tends to form $\mathrm{PuO}$, with few imperfections in the crystalline tat îice structure. There are indications that this "high-temperaturefired" plutonium is difficult to leach and recovery is more difficult.

3. Materials. Materials selection poses a real challenge to the designer of a radioactive-waste incinerator. The factors of high temperature, expansion and contraction, corrosion, stress fatigue, and erosion must be considered.

a. High Temperature. High temperatures are a necessity if complete combustion is to be achieved within a reasonable time. However, high temperatures do restrict the types of materials that can be used. One cause of failure in the early incinerators was the warping of the steel incinerator stall. At present. most incinerators have some iype of ceramic lining in the combustion chamber; but these linings erode, spall, and crack, and the lining must be replaced. Because radionuclides can migrate into the refractory, the refractory sometimes must be treated for radionuclide recovery after it has been removed from the furnace. Although ducts can be iined with refractory, it is difficult to find suitable high-temperature materials for the off-gas cleanup system. Water-walled boilers or water-jacketed vessels might be considered, but water walls tend to develop leaks that would present a containment problem and perhaps a criticality problem. Water walled waste-heat boilers might be used after the combustion chambers but, again, problems from leaking tubes must be considered.

b. Expansion and Contraction. High tomperatures also introduce a ralated materia!s problem: the difference in the thermal coefficients of expension of various materials. It is necessary to "hang" the ceramic lining of the combustion chamber and to provide slip joints, bellows, etc.. for thermal expansion. These provisioi.s all add additional design requirements and complexity to the system.

c. Corrosion. Corrosion, both high- and lowtemperature. is an ever-present problem in incinerator systems, particularly if the wastes contain compounds of chlorine, fluorine, or sulfur. One solution is to minimize the pr sduction of acid gases. Diffusion of acid gases cooled to near the dew point can be restricted by application of a mastic coating to the incinerator. Special materials such as titanium, riber glass. polyethylene. and graphite can be used in the cleanup train, but many of these materials are expensive. difficult to fabricate, cannot withstand nigh temperature, or are structurally weak. In the liquid-gas scrubber system, alkaline compounds added to maintain a pH of 7 or above can reduce corrosion. More data on high- and low-temperature corrosion, and corrosion-resistant materials can be found in the sources at the end of this section.

d. Siress Fatigue. The materials in an incineration facility are not only subjected to a corrosive at mosphere and high temperatures, but are also sub. jected to thermal and mechanical stress. Usually an incinerator is run for a while and then shut down. After it has cooled. it may be started up only a few hours later. and this type of thermal cycling is extremely damaging to materials. In addition to stress from thermal cycling, the material must often withs. tand mechanical stress. linits such as fans and waste shredders set up conditions in which stress fatigue can occur. 
c. Erosion. The materials also must vithstand erosion and abrasion. Consequently, both liquid and gas streams should carry as little entrained inaterial as possible, and abrasion-resistant materials should be used in construction if maintenance problems are to be minimized.

4. Criticality Control. Incineration of radioactive wastes poses a special problem, that of criticality control. If $235 \mathrm{U}$ or plutonium is in the waste. conditions must be such that the material can never form a critical mass. Thus, all liquors must be confined to containers of safe geometry. water for fire contrnl must be carefully metered and applied. special siorage facilities must be used, and the incineration facility nust be cleaned regularly to prevent any potential build-up of fissionable material sufficient to form a critical mass.

Ash can lodge in nooks and crannies, piutonium and $233 \mathrm{U}$ can migrate into the refractory; accidental discharge of 'iquid is always possible; and build-up can occur in scrubbing liquids. For these reasons. criticality control involves a great deal of care in assay techniques and in the design, operation, and maintenance of the incineration facility.

\section{SOURCes - Ceneral}

D. A. Vaughan, P. D. Miller, and W. K. Boyd, "Fireside Corrosion in Municipal Incinerators versus PVC Content of the Refuse." in Proc. Nat. Incinerator Conf. 6. 179-189 (1974).

R. Heimburg, "Environmental Effects of the Incineration of Plastics," in Symp. Solid Industrial Wastes. Houston. TX, February 28-March 4, 1971 (Am. Inst. of Chem. Eng.. New York).

f. A. Brink and C. N. Dougald, "Particulate Removal from Process Exhaust Gases," Intern. Sulfite Conf., Eoston, October 30-November i. 1972.

E. L. Carls and N. M. Levitz, "Blowback of Sintered Metal Filters: A Review of Tests and Operating Experience." Argonne National Laboratory report ANL.7392, (November 1967).

J. .I. Santoleri, "Chlorinated Hydrocarbon Waste," Chem. Eng. Prog. 69. 68-74 (1973).

P. Davids. K. Gerhards, and W. Brocke, "Present and Future Air Pollution by Refuse Incineration Plants - Emission and Emission Reduction," Staub Reinhalt. Luft 33, 460-467 (1973).
A. A. Carotti and F. R. Kaiser, "Concentrations of Twenty Gaseous Chemical Species in the Flue Gas of a Municipal Incinerator." J. Air Pollut. Contr. 22. No. 4. 248-253 (1972).

S. K. Kempner, E. N. Seiler, and D. H. Bowman, "Performance of Commercially Available Equipment in Scrubbing Hydrogen Chloride Gas," I. Air Pollut. Contr. 20, Nn. 3, 139-143 (1970).

"Background Infermation for Propused New-Source Performance Standards: Steam Generators, Incinerators, Portland Cemeni Plants, Nitric Acid Plants, Sulfuric Acid Plants," Environmental Protection Agency, Research Triangle Park, NC, August 1971. pp. 20-25.

E. A. Boettner, G. L. Ball, and B. Weiss. "Conibustion Products from the Incineration of Plastics." Environmental Protection Agency report EPA-670/2. 73-049 (1973); also issued as NTIS report PB-222. 001.

P. D. Miller et al., "Corrosion Šcudies in Municipal Incineratoss," Environmental Protection Agency. National Environmental Research Center. Cincinnati, $\mathrm{OH}, 1972$, SW-72-3-3.

D. A. Vaughan, M. Y. Anastas, and H. H. Krause. "An Anaiysis of the Current Impact of Plasti: Refuse Disposal upon the Fnvironment." |Battelle Meriorial Inst., Columbus, $\mathrm{OH}$.

H. 1. White. Industrial Electrostatic Precipitation (Addison-Wesley, Reading. MA, 1963).

M. Robinson, "Electrostatic Precipitation," in Air Pollution Control, Part I (Wiley-Interscience, New York, 1971), pp. 227-335.

F. Loffler, "Collection of Particles by Fiber Filters." in Air Poliution Control, Part l (Wiley-Interscience. New York. 1971). pp. 337.375.

B. W. Lancaster and W. Strauss, "Condensation Effects in Scrubbers," in Air Pollution Control, Part I (Wiley-Interscience, New York, 1971), pp. 377-427.

R. E. Treybal, Mass-Transfer Operations (McGrawHill, New York, 1955).

J. R. Fair, D. E. Steinmeyer, W. R. Penney, and I. A. Brink, "Liquid-Gas Systems," in Chemical Engineers" Handbook, 5th ed. (McGraw-Hill. New York, 1973), Sec. 18. 
"Are These Incinerators the Answer to Plastics Waste?" Mod. Plast. 47, 102-103 (1970).

H. S. Jordan, "Problems in the Incineration of Radioactive Wastes," in Proc. Hecith Phys. Soc. (June 1956), pp. 152-158.

A. C. Stern, "Efficiency, Application, and Selection of Collectors," in Air Pollution, Vo! III (Academic Press, New York, 1968), pp. 319-435.

C. F. Gottschlich, "Source Controi by Electrostatic Precipitation," in Air Pollution. Vol III (Acudemic Press, New York, 1968), pp. 437-456.

S. Calvert, "Source Control by Liquid Scrubbing," in Air Pollution Vol III (Academic Press. New York, 1968), pp. 457-496.

S. Oglesby and B. G. Nichols. Manual of Electrostatic Precipitator Technology, Pts. 1 and 2. (Southern Research Inst., Birmingham. AL, 1970).

O. J. Wick, Ed.. Plutonium Handbook, Vols. 1 and 2 (Gordon and Breach, 1967).

J. A. Danielson. Ed., Air Pollution Engineering Manual (HEW. National Center for Air Pollution Control, Cincinnati, OH. 1967).

Techniques for Controlling Air Pollution from the (1peration of Nuclear Facilities (IAEA. Vienna, 1966). pp. 19-38.

.J. Jackson. "Gas Absorption Tower," in Gas Purification Processes (George Newnes Lid.. London, i964), pp. 121-186.

1. C. McCabe, in Proceedings of the L'nited States Technical Conference on Air Pollution. Section III Equipment Panel (McGraw-Hill Book Co.. New York. 1952), pp. 264-394.

"Cyclone Dust Collectors," Engineering report prepared for American Petroleum Institute. New York. 1955.

"Air and Gas Clean-up Equipment 1972," Joyes Data Corp.. Park Ridge. N.J (1972).

\section{SOURCES - Compustion}

B. Lewis and G. von Elbe, Combustiūn, Flames and Explosions of Gases, 2nd ed. (Academic Press. New York, 1968).
V. N. Kondrat'ev, "Kinetics of Chemical Gas Reactions," (2 vols.), AEC translation AEC.tr-4493.

D. J. von Lehmden, "Basic Combustion Concepts," in Visible Emissions Evaluation, a course conclucted by Inst. for Air Pollution Training (HEW, Research Triangle Park, NC), Sec. 2 .

R. H. Essenhigh and G. Gelernter, "Systematic Appraisal of Incinerator Research Requirements," Symp. Air Pollution Control through Applied Combustion Science, New York, November 26-30, 1967 (Am. Inst. Chem. Eng.).

E. S. Monroe, "Combustion Fundamentals: An Approach to the Design of Industrial Incinerators," Am. Soc. Mech. Eng. report ASME-72-WA/1W-1 (1972).

E. S. Domalski and G. T. Armstrong, "Thermodynamic Data for Incinerator Engineering," Am. Soc. Mech. Eng. report ASME-72-WA/1W-2 (1972).

"Combustion Fundamentals for Waste Incinerstion," report of an ASME Subcommittee on Fundamental Combustion Studies (Am. Soc. Mech. Eng.. New York, 1974).

C. F. Prutton and S. H. Maron. "Kinetics of Homogeneous Reactions," in Principles of Physical Chemistr. (Macmillan. New York. 1953), pp. 612. 665 .

\section{SOURCES - Incineration}

F. R. Kaiser. "Chemical Analyses of Refuse Components," Visiole Emissions Eualuation, a course conducted by Inst. for Air Poilurion Training (HEW. Research Triangle Park, NCl, Sec. 4.

R. D. Reed, Furntece Operations (Gulf Publishing Co., Houston, 'TX. 1973).

R. C. Corey. Principles and Practices of Incineration (Wiley-Interscience. New York. 1969).

F. L. Cross. Jr.. "Controlled Air Incinerators." Pollut. Fng., December 1973, pp. 30-32.

B. Baum and C. H. Parker. Solid Waste Disposal. lil 1 . Incinoration and Landfill, (Ann Arbor Science Publishers. Ann Arbor. MI, 1973). 
National Center for Resource Recovery, Inc., Incineration (Lexington Books, Lexington, MA, 1974).

I.I.A. Incinerator Standards (Incinerator Institute of America, New York, 1968).

J. A. Fife, "Solid Waste Disposal: Incineration or Pyrolysis," Envinon. Sci. Technol. 7, 308-312 (1973).

R. B. Engdahl, "Solid Waste Processing," US Public Health Service Pub. No. 1856 (1971).

J. F. Ferrel, "Sludge Incineration," Pollut. Eng., March 1973, pp. 36-39.

Proc. National Incinerator Conf., New York, 1968 (Am. Soc. Mech. Eng.. New York, 1968).

Proc. National Incinerator Conf., Cincinnati, 1970 (Am. Soc. Mech. Eng., New York, 1970).

Proc. Nutional Incinerator Conf., New York, 1972 (Am. Soc. Mech. Eng., New York, 1972).

\section{B. Incineration vs Radionuclide Content and Waste Type}

The degree of seriousness of the problems just aiscussed is dependent upon (1) the radionuclides contained in the waste and (2) the chemical composition of the wastes. Typical process flow diagrams for various wastes containing various radionuclides are given in the appendix.

1. Radionuclide Content. The particular radionuclides to be contained in the waste and the amount of contamination they will supply are determining factors in how the facility is designed and operated. For example, if wastes are slightly contaminated with beta-gamma-emitting wastes, the operation and design of the facility require a design different from that for wastes contaminated with large quantities of alpha-emitting nuclides.

2. Waste Type. The chemical composition of the waste also influences the design and operation of the facility. Cellulosic wastes usually have fairly uniform heat content and are fairly easy to incinerate, whereas materiais, such as plastic, with a low melting point and a heating value much higher than cellulosic wastes can cause problems. In addition, there are those materials, such as PVC, that produce acid gases during combustion. The increases in problems and incinerator-design requirements associated with different types of waste are indicated in Fig. 50.

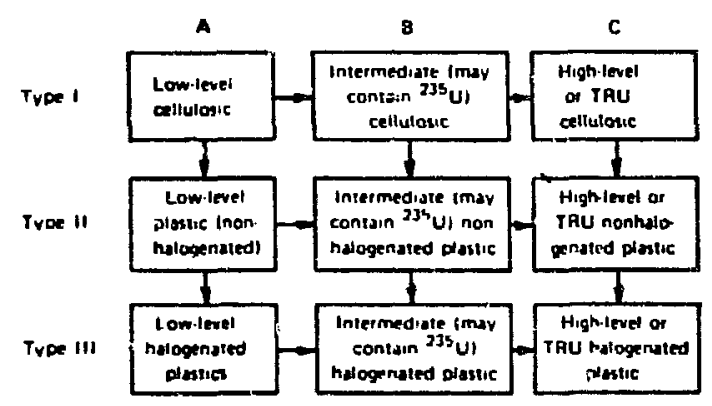

Fig. 50.

Problems and design requirementz associated with different types of waste. Arrous indicate increasing problems (and need for increasing complexity in design). Anv "box" roceives all the problems associated with the box from which the arrow originates. Thus high-level or TRU-containing halogenaterl plastic waste has all the problems associated with high-leve! or $T R U$-cortaining nonhalogenated plastic waste plus all tine problems associated wich intermediate-lovel (may cantain enriched uranium) halo:tenated plastic wastes. 


\section{APPENDIX}

\section{WASTE TREATMENT BY CONVENTIONAL INCINERATION FOR WASTES OF DIFFERENT COMPOSITIONS AND RADIONUCLIDE CONTAMINATIONS}

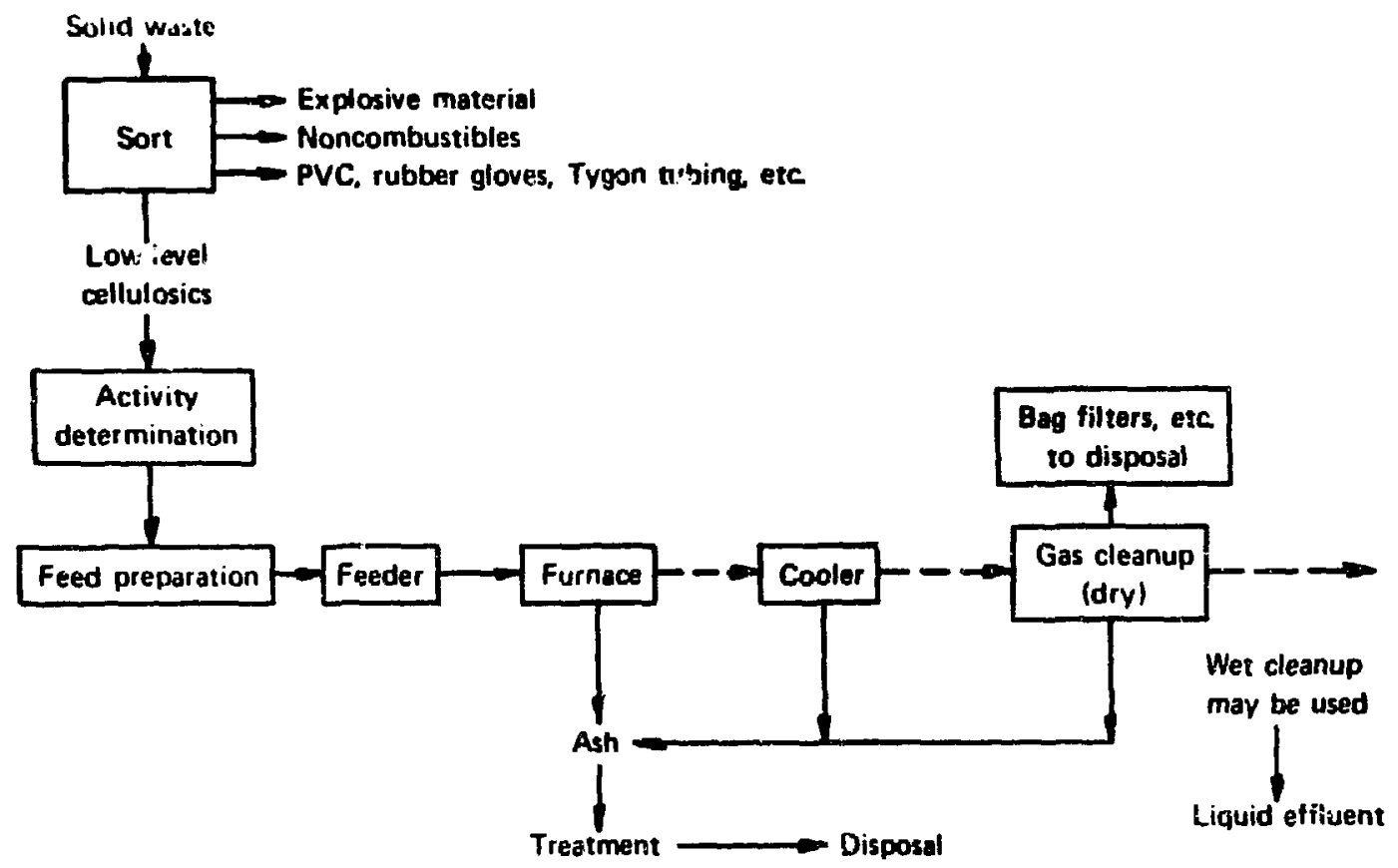

I-A. Wastes Composed Chiefly of Cellulosics and Animal Remains and Containing Small Amounts of Radionuclides

Process Description: Combustible wastes are oxidized to gaseous products and solid ash residues. Volume and composition of gaseous products depend on how furnace is heated, what is used as an oxygen source (air-oxygen). type of cooling used, etc.

Development Status: Fairly widely used (for lowlevel wastes composed of paper. clothing, wood. animal remains) with many variations in type of feed preparation. loading. Maintenance and good design are necessary for satisfactory operation.

Applicable Waste: All combustible solids except rubber and/or plastics and explosive materials con. taining low levels of redioactivity.

Volume/Weight Change: Depends on how com. plete oxidation may be and original ash content of wastes.
Final Product Form: Dry ash which may be further treated for increased stabilization.

Product Stability: Untreated ash may be casily dispersed and may be leachable. Inertness of material depends on completeness of combustion.

Radionı slide-Recovery Capability: Usually none.

Process Safety: Since waste contains only a small amount of radionuclide-containing material, tight containment at all times is less critical and the offgas cleanup system usually needs to be only moderately efficitnt. A design to avoid filter fires in the off-gas system is important. Fire-extinguishing capability is necessary. Controls and monitors to prevent explosicns and excessive furnace pufting are advisable.

Materials of Construction: Materials suitable for use at high temperature and which can undergo thermal sycling. Provision for thermal expansion is necessary. Cooling of loading doors sometines necessary. 
Pretreatment of Wastes: Sorting and some size reduction of bulky items plus determination of radionuclide contamination. Can include shredding or special packaging.

Potential Problem Areas: (1) Warping, (2) spallation, (3) plugging, (4) fires, (5) incomplete combustion causing high carbon content in ash, clogging (and fires) in off-gas cleanup system, (6) corrosion (sulfur in paper is sometimes a problem), and (7) containment, including furnace puffing and explosion.

Economics: Technique has not been used in some cases hecause burial was thought to be less expensive than incineration. Few data are available to substantiate this decision.

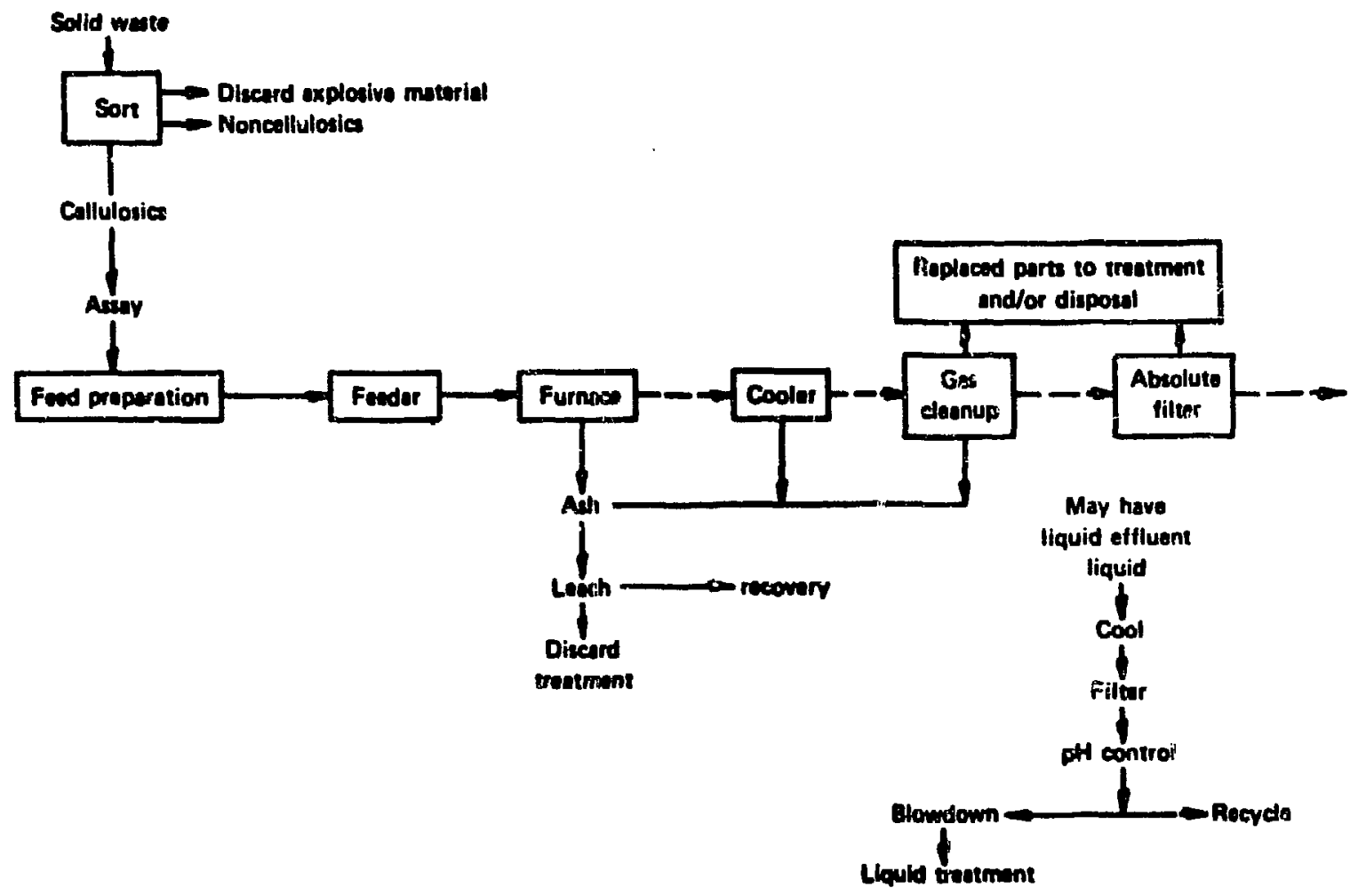

I-B. Wastes Conposed Chieny of Cellulosics but Containing Fairly Large Quantities of $\beta \cdot \gamma \cdot$ Emitting Radionuclides Plus $235 \mathrm{U}$ and Perhaps Small Quantities of TRIJ Radionuclides

Process Description: Combustible wastes are oxidized to gaseous products and solid ash residues.

Development Status: Lised to a limited extent for recovery of uranium radionuclides. Good design. proper operation necessary.
Applicable Waste: All cellulasic wastes containing intermediate levels of radioactivity, including some enriched uranium.

Volume/Weight Change: Dependert on completeness of combustion and composition of original wpete. Similer to that obtained in other cellulosic incineration categories.

Final Product Form: Dry ash which may be leacned for radionuclide recovery (uranium). 
Product Stability: Same comments as for low-level cellulosic waste.

Radionuclide-Recovery Capability: Uranium may be recovered if sufficient quantity is in the ash.

Process Safety: Containment, criticality control (if $235 \mathrm{U})$ plus safeties described for low-level riclosic waste.

Materials of Constiruction: Same as for low-level cellulosic waste incineration.
Pretreatment of Wastes: Same as for low-level cellulosics.

Potential Problem Areas: Same as for low-level cellulosics plus criticality control ( $235 \mathrm{U})$; increased need for containment.

Economics: Incineration used at several facilities for recovery of uranium; therefore appears to ba economically feasible for this application.

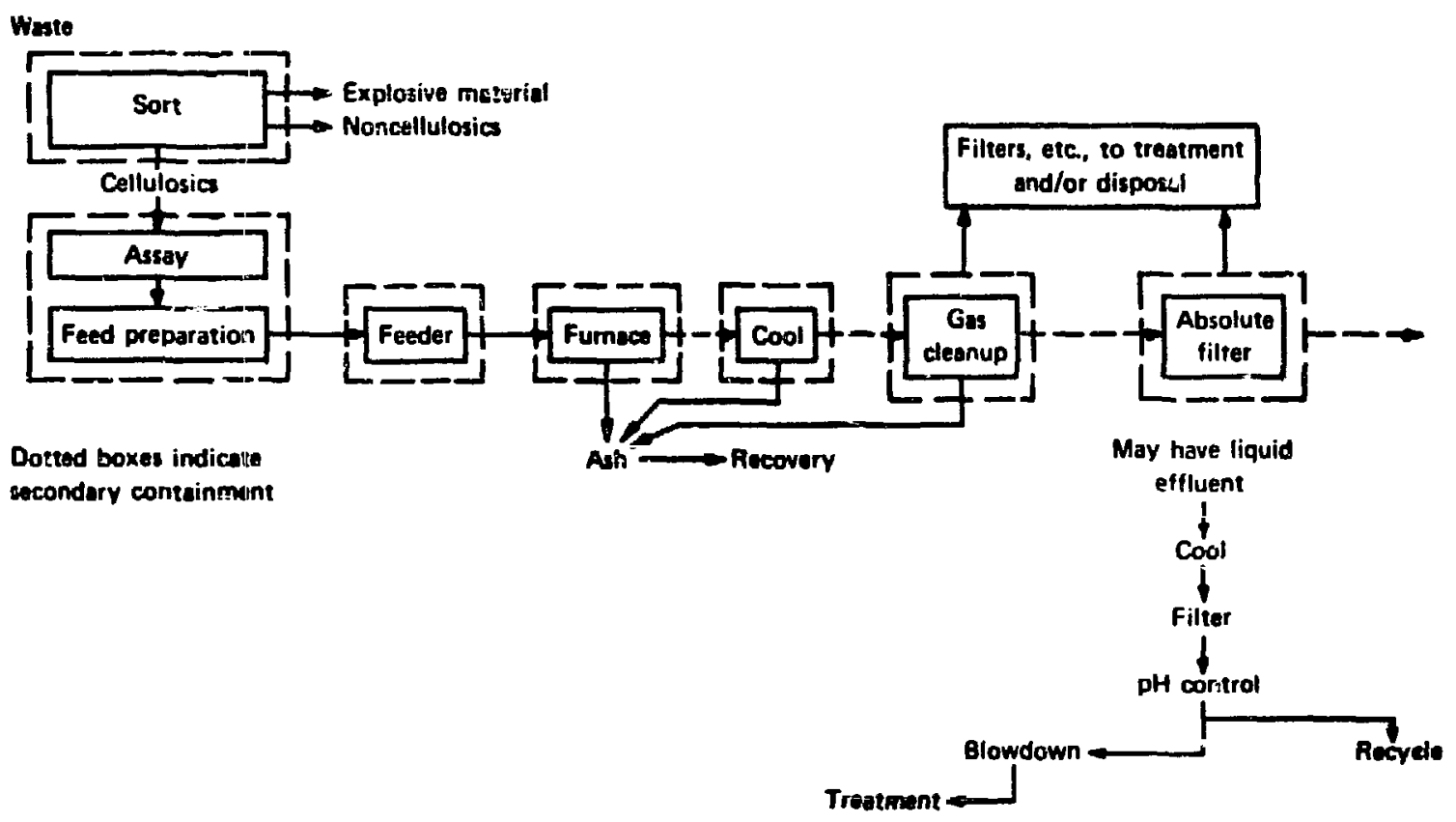

I-C. Wastes Composed Chiefly of Cellulosics and Containing Significant Quantities of TRU Radionuclides or High-Level Waste

Process Description: Same as for low-level cellulosics.

Development Status: Used to some ex ${ }^{*}$ nt for plutonium recovery from wastes.

Applicable Waste: TRU-cor.taminated, cellulosictype wastes.

Volume/Weight Change: Same as for low-level cellulasics.
Product Stability: Ash usually leached to recover radionuclides.

Plutonium-Recovery Capability: Combustion at high temperatures tends to produce plutoniumcontaining compounds which in some cases are difficult to leach. Combustion at low temperatures tends to produce an ash high in unburned carbon which can cause problems during leaching.

Process Safety: Same problems as with low-level cellulosics; also, secondary containment is considered desirable for all operations from sorting to final off-gas cleanup train (including maintenance). Shielding during material sorting is desirable. High 
levels of radioactivity in the waste require an efficient off-gas cleanup system with secondary processing of liquid-effluent waste streams, HEPA filters, etc. Extensive use of controls is necessary to prevent and to warn of equipment malfunction and to prevent explosions, etc. Strict control of (1) amount of radioactive material in the system, and (2) design of system (especially liquidcontaining units) is necessary for criticality control. It is undesirable to use natural gas because of the explosion hezard.

Materials of Construction: Same as for low-level cellulosics.
Pretreatment of Wastes: Sorting, assay, size reduction of bulky items; can include shredding. or repackaging.

Potential Problem Areas: (1) Warping of components, (2) incomplete combustion, (3) containment, (4) corrosion, (5) plugging, (6) criticality control, and (7) fires and explosions.

Economics: Incineration is not usually the most expensive part of radionuclide recovery.

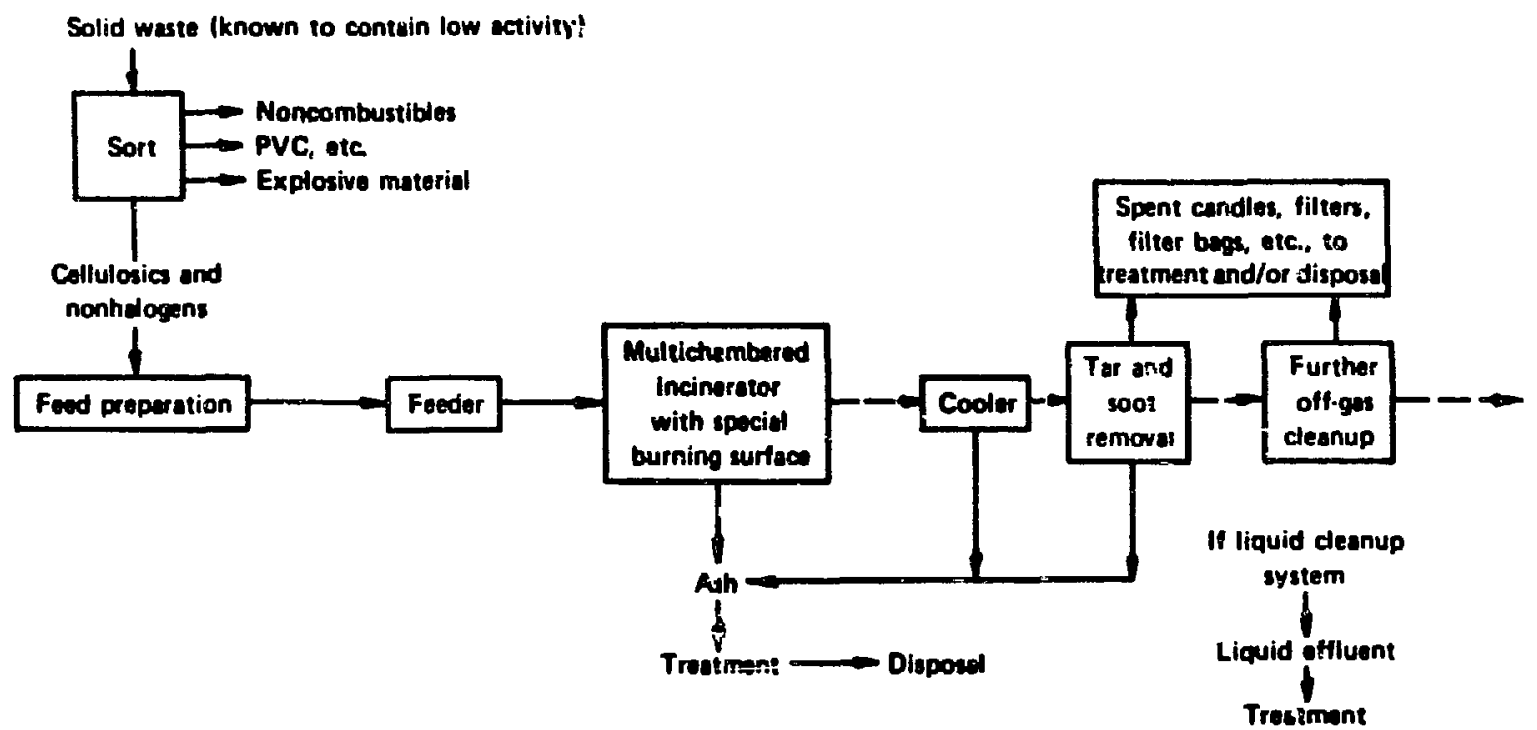

II-A. Wastes Composed of Cellulosics plus Nonhalogen or Non-Sulfur-Containing Plastics and Rubber Contaminated with Luw Levels of Radioactivity

Process Description: Combustible wastes are oxidized to gaseous products and gsh residue.

Development Status: Special designs have been developed, especially in foreign countries, to deal with the incineration of plastic. Further development for more reliable and maintenance-free systems may be desirable.
Applicable Waste: All combustible, nonexplosive solids except compounds that produce acid gases upon incineration and contain only low levels of activity.

Volume/Weight Change: As a rule, the coinplete combustion of plastic produces little $s$ lid residue.

\section{Final Product Form: Ash.}

Product Stability: Untreated ash may be easily dispersed and may be leachable - inertness of material depends upon completeness of combustion. 
Radionuclide-Recovery Capability: Not applicable to low-level wastes.

Process Safety: Complete containment is less necessary because of low activity, and criticality control is not a major problem. Incineration of plastic can give pressure surges in furnace. Dripping plastic can pose problems. Incomplete combustion can cause plugging and fires in the off-gas system. Flashback can occur during loading. Flameout of auxiliary burners is possible.

Matcrials of Construction: Similar to those for lowlevel rellulosic-type wastes.
Pretreatment of Wastes: Sorting, size reduction, assay (may inciude shredding and packaging).

Potential Problem Areas: (1) Clogging and plugging, (2) explosions and fires, (3) puffing (containment). (4) warping and spallation of materials, (5) corrosion, and (6) incomplete combustion.

Economics: Consideration of long-term costs is important.

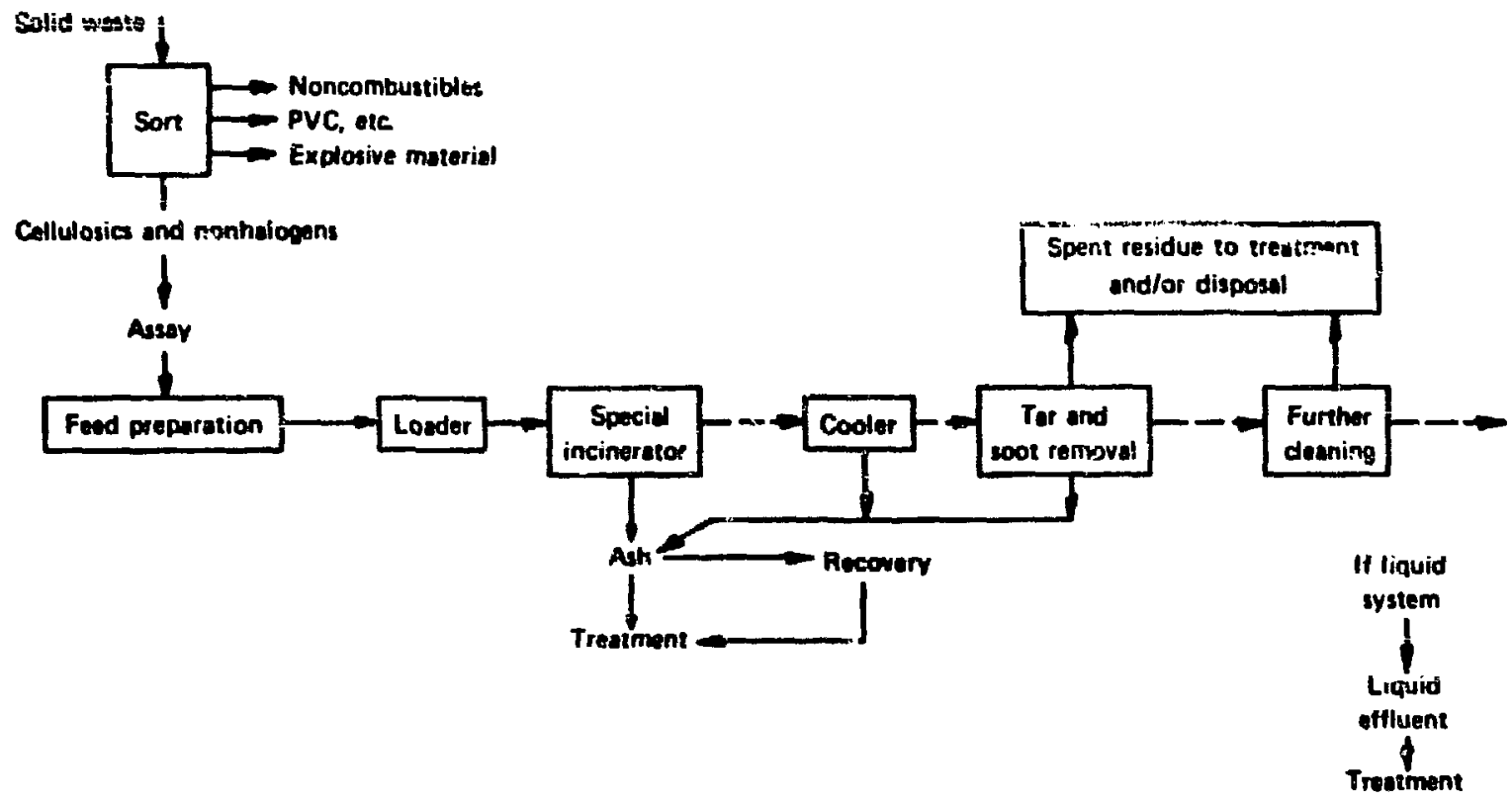

II-B. Wastes Composed of Cellulesics plus Nonhalegen or Non-Sulfur-Contcining Plastics and Rubber Contaminated with Intermediate Levels of Fadioactivity Including Enriched Uranium

Prorejs Description: Com:bustible wastes are oxidized to gaseous products and ash residue.

Development Status: Similar to iow-level wastes of similar material composition.

Applicable Waste: All combustible, nonexplosive solids except compounds that produce acid gases upon incineration and do not contain large amounts of radionuclides including TRU.

Volume/Weight Change: Similar to low-level wastes of similar material composition.

\section{Final Product Form: Ash.}

Product Etability: Unireated ash may be easily dispersed and may be leachable, however, under conLitions of complete combustion it is inert. 
Radionuclide-Recovery Capability: Uranium may be recovered from wastes containing uranium.

Process Safety: Incineration of plastic may produce pressure surges in the furnace and plugging of ait vents for furnace, etc., and incomplete combustion of the plastic may cause problems in the off-gas cleanup system. All explosive material should be excluded and if natural gas burners are used suitable controls should be applied. Special precautions to prevent flashback should be taken. Criticality control for enriched uranium containing ash is important. Adequate monitoring is important.

Materials of Construction: Similar to those for cellulosic-type waste incineration.
Pretreatment of Wastes: Sorting, size reduction, and assay. May include shredding or special packaging.

Potential Problem Asreas: (1) Plugging caused by scout produced in incomplete combustion. (2) fires and explosions, (3) pressure surges in furnace, (4) clogging caused by dripping plastic, (5) currrosion, (6) spallation and warping, (7) criticality control, and (8) migration of uranium into furnace lining.

Economics: Incineration is used in the recovery of uranium from wastes.

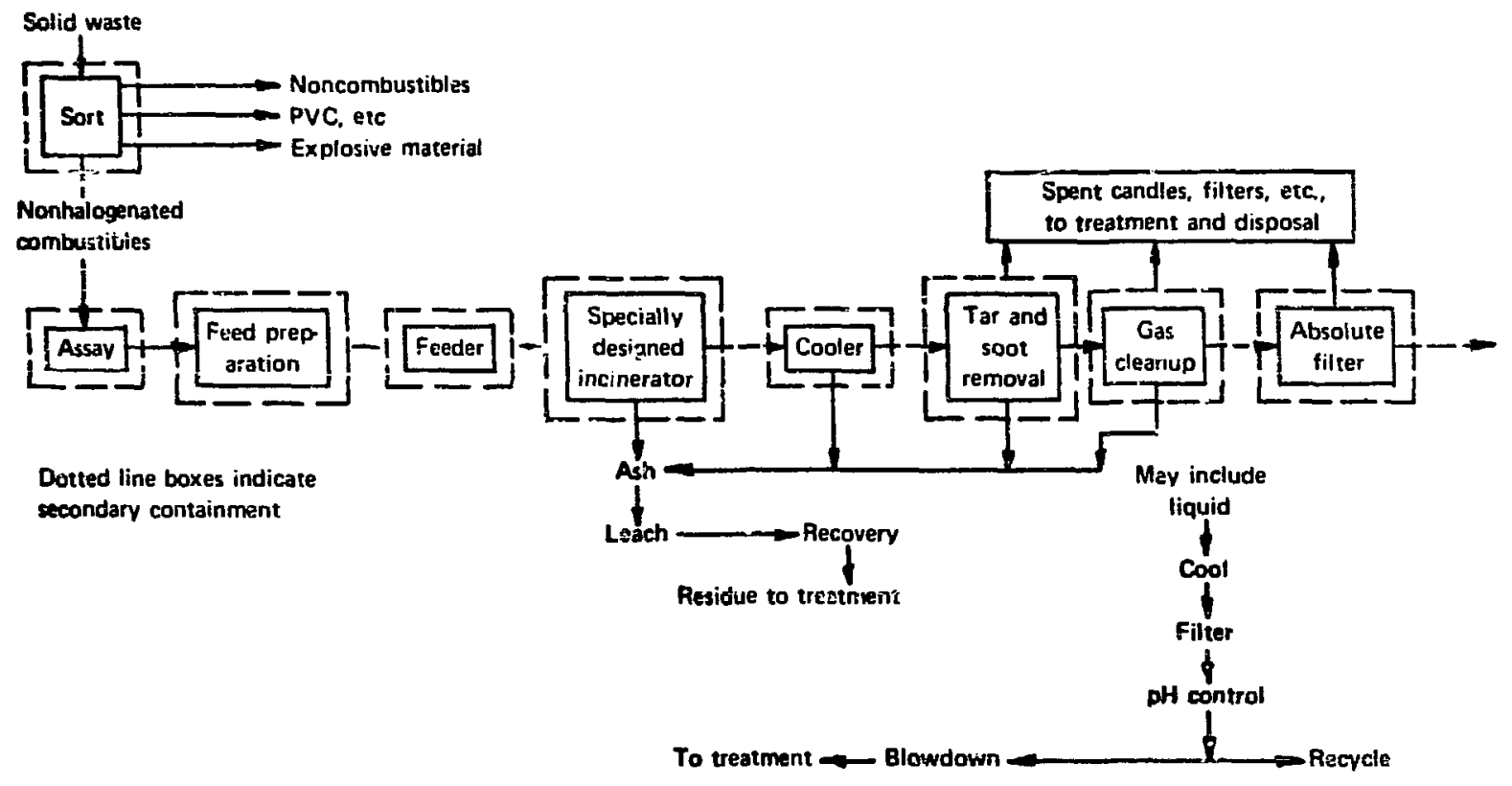

II-C. Wastes Composed of Cellulosics, Animal Remains, and Plasties Containing No Compounds that Form Acid Gases upon Combustion and Containing Fairly Large to Large Amounts of Radionuclides Including TRU

Process Uescription: Combustible wastes are oxidized to gaseous products and ash residue.

Development Status: Spenial degigns for incinerating plastics have been developed. Additional development work to reduce maintenance and improve reliability may be desirable.

Applicable Waste: All combustible, halogen- and sulfur-free, nonexplosive solids that contain signifi:cant quantities of redionuclides, including TRU.

Volume, Weizht Change: Plastic, upon complete combustion, usually produces little solid residue.

Final Product Form: Ash. 
Product Stability: If high temperatures occur in incinerator, "high-fired plutonium" may be difficult tuleach.

Radionuclide-Recovery Capability: Leaching techniques are available; sornetimes several stages are necessary.

Process Safety: Same problems as with low-level wastes of similar composition, plus problems of containment and criticality.

Materials of Construction: Materials suitable for use at the temperatures necessary for good performance of the system.
Pretreatment of Wastes: Sorting, size reduction of bulky items, assaying. May include shredding and special packaging.

Potential Problem Aress: Same as for same type of waste containing small amounts of radionuclides; also criticality control, operator shielding, and containment.

Eco:omics: Incineration is usually not the major cost factor in recovery of radionuclides from waste.

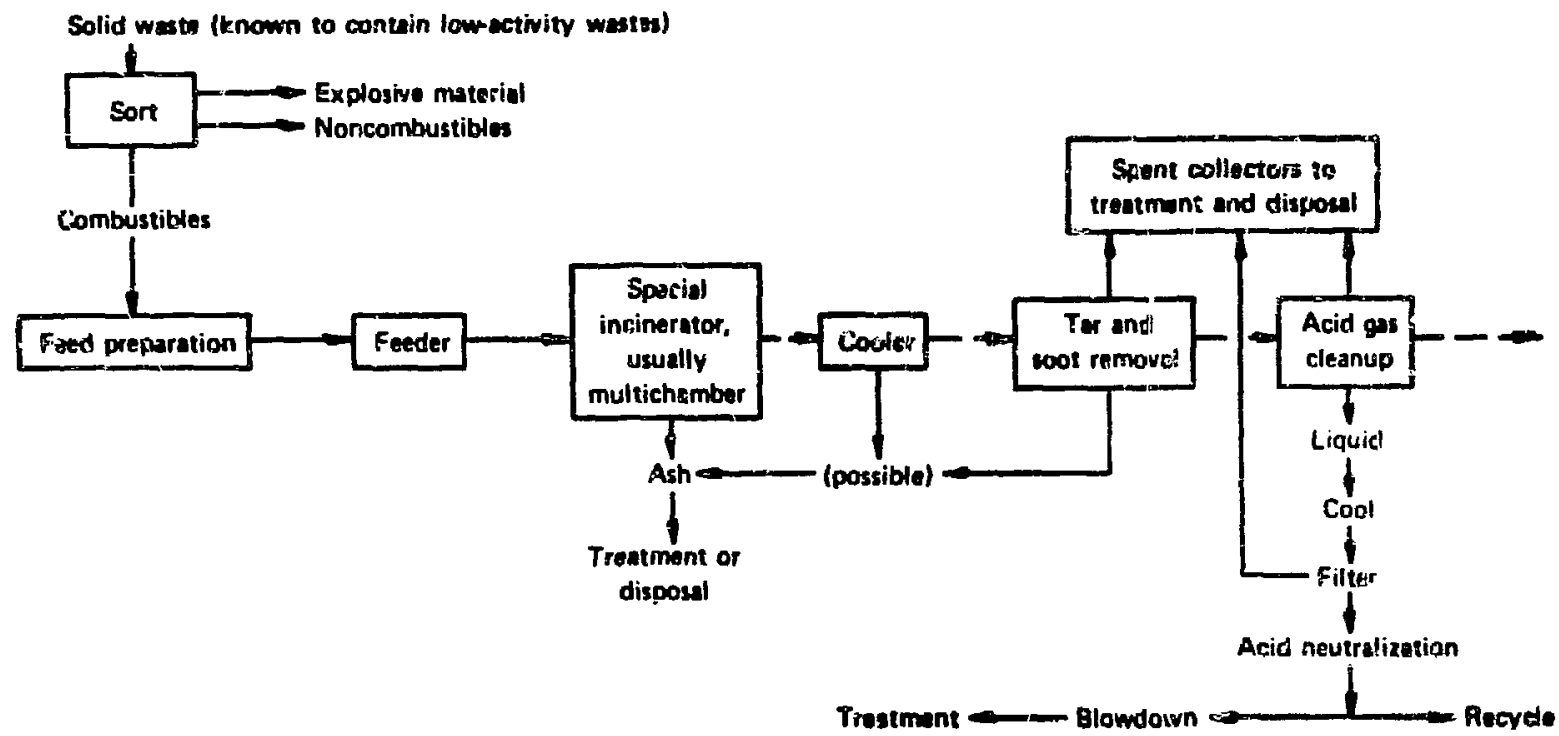

III-A. Low-Level Wastes Composed of Cellulosics, Animal Fiemains, Plastics (including PVC), lubber Gloves, and Tygon Tubing (Materiais that Produce Acid Gases upon Incineration)

Process Description: Combustible wastes are oxidized to gaseous prcducts and ash residue.

Development Status: Special designs have been de"eloped for incinerating plastics and for treating off-gases containing acid gases. Further developmerit work to improve reliability and reduce maintenance desirable.
Applicatle Waste: All low-level combustib!e wastes, excluding explcsive materials.

Voiume/Weight Change: Plastic, upon complete combustion, usually produces little solid residue.

Pinal Product Form: Ash.

Product Stability: Ash can be easily dispersed if nit contained. Inertness of ash depends on completeriess of combustion.

Radionuclide-Recovery Capability: Ussually not. economical for low-level waste. 
Process Safety: Problems similar to those occurring in combustion of low-level, nonhalogen-containing plastics, plus requirenent for cleanup of an acidgas-containing off-gas.

Materials of Construction: Materials suitable for use at high temperatures and/or in corrosive environments.

Pretreatment of Wastes: Sorting, size reduction, assay. May include shredding or repackaging.
Potential Problem Areas: (1) Corrosion, (2) plugging and clogging (especially with plastic waste), (3) containment, (4) spullation and warping, (5; explosions and fires, and (6) adequate renoval of $\mathrm{HCl}, \mathrm{HF}$, etc., from off-gases.

Economics: Irsineration of halogen- and sulfurcontaining combustibles requires a complex furnace and cleanup system.

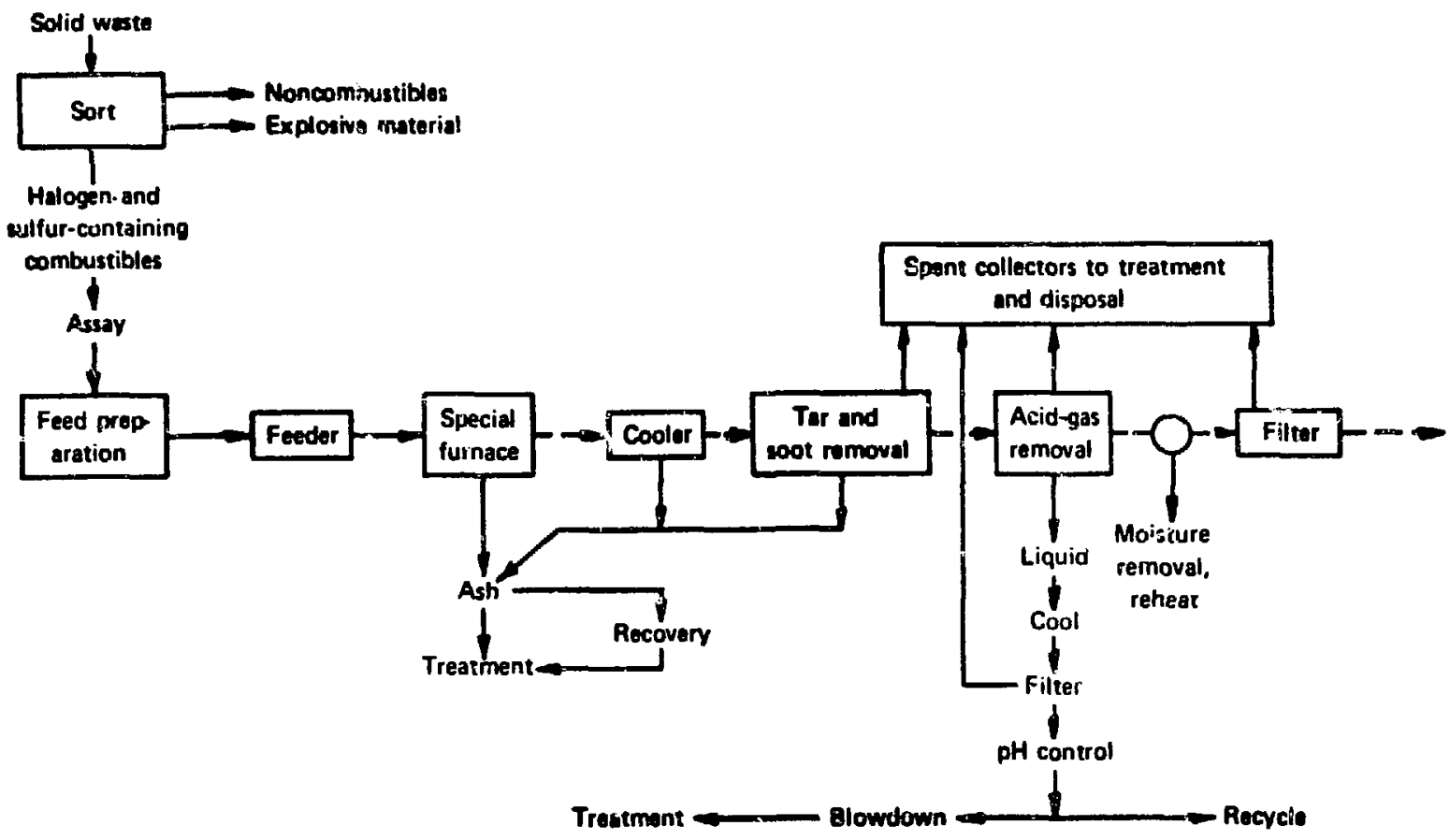

III-B. Intermediate-Level Wastes Composed of Celluiosics, Animal Remains, Plastics (Including PVC), Rubber Gloves, and Tygon Tubing and Including Enriched Uranium

Process Degcription: Similar to that for low-level wastes of similar composition.

Development Status: Similar to that for low-level wastes of similar composition.

Applicable Wrste: All intermediate-level, contaminated, combustible waste, excluding explosives.
Volume/Weight Change: Dependent on composition of waste; plastics give little residue upon complete combustion.

Final Product Form. Ash.

Product Stability: Relatively inert if combustion is complete; however, ash can be dispersed and leached.

Radionuclide-Recovery Capability: Uranium may be recovered. 
Frocess Safety: Same problems as with incineration of intermediate-level-containing nonhalogenated plastic, plus requirement for removine acid gases (principally $\mathrm{HCl}$ ) from the off-gas stream.

Materials of Construction: Great care must be taken in the selection of materials that will withs. tand necessary temperatures and withstand corrosive acids at temperatures below the dew point. Usually, materials such as titanium, graphite, Pyrex, and special plastics are used in the off-gas cleaning train.

Pretreatment of Wastes: Similar to that required with cther types of intermediate-level waste.
Potential Froblem Areas: (1) Plugging caused soot formation during incomplete burning of rub and plastic, (2) corrosion, (3) containm (including pressure surges in furnace), (4) cloggi (5) warping, (6) fires, (7) rubber gloves may nı special handling to prevent clogging, (8) critica control, and (9) migration of uranium into furn lining.

Economics: System more expensive than $t$ designed for incineration of nonacid gas-form wastes.
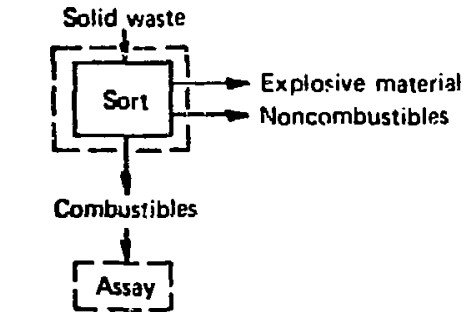

boxes indicate secondary containment

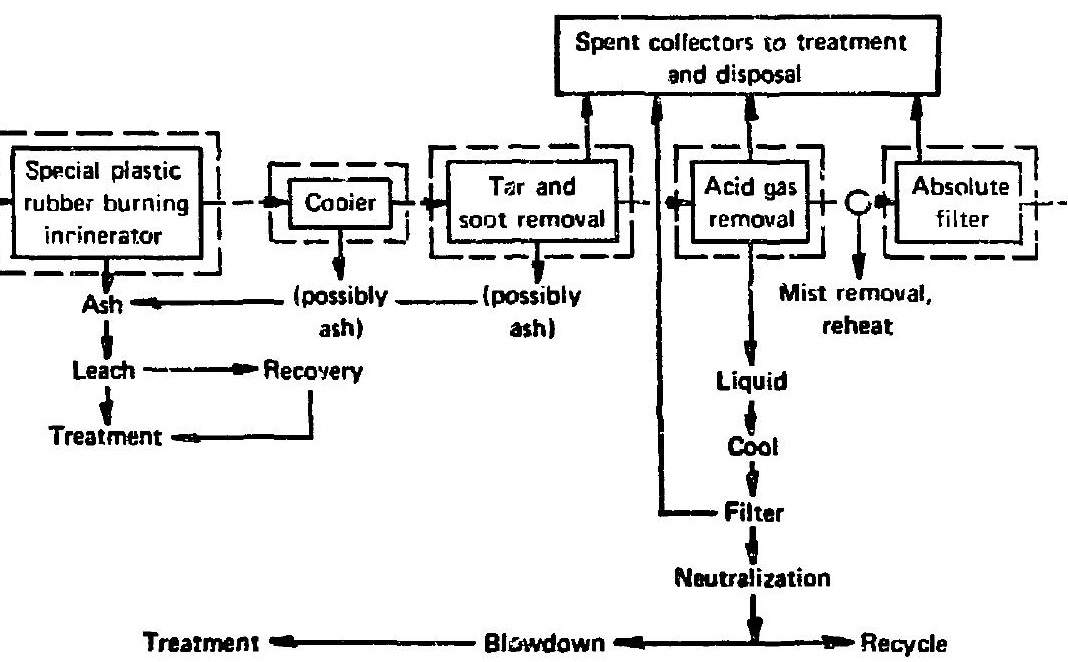

III-C. Fairly High to High-Level Wastes Composed of Cellulosics, Animal Remains, Plastics (Including PVC), Rubber Gleves, and Tygon Tubing and Including TRU Wastes

Process Description: Combustible wastes are oxidized to gaseous products and ash residues.

Development Status: Similar to that for low-level wastes of similar composition.
Applicable Waste: All high.level or modera high-level combustible, nonexplosive-type waste

Volume/Weight Change: Complete incineratio plastic leaves little residue.

Final Product Form: Ash.

Product Stability: Relatively inert upon comp combustion, although ash may be easily dispers 
Radionuclide-Recovery Capability: Same problems as with ash from other types of incinerated waste containing plutonium.

Process Safety: Shielding, containment, and criticality control are of particular importance.

Materials of Construction: Similar to thase used in the system for low-level wastes of similar composition.

Pretreatment of Wastes. Sorting, assay, reduction of bulky items. May include shredding and repackaging.
Potential Problem Areas: (1) Containment (special problem from incineration of rubber and plastics plus TRU-radionuclide content), (2) corrosion (particularly serious), (3) plugging and clogging, (4) warping and spallation, (5) fires, (6) slagging, and (7) criticality control.

Economics: Incineration of acid-Corming wastes requires special cleanup system, hence increases cost over incineration of nonacid-forming wastes. 